\title{
Oil palm expansion among Indonesian smallholders - adoption, welfare implications and agronomic challenges
}

\author{
Dissertation \\ zur Erlangung des Doktorgrades \\ der Fakultät für Agrarwissenschaften \\ der Georg-August-Universität Göttingen
}

vorgelegt von

Michael Andreas Euler

geboren in Bad Kreuznach

Göttingen, März 2015 
D 7

1. Referent: Prof. Dr. Matin Qaim

2. Korreferent: Prof. Dr. Bernhard Brümmer

Tag der mündlichen Prüfung: 13.05.2015 


\section{SUMMARY}

Oil palm has become one of the most rapidly expanding crops throughout the humid tropics. Over the last two decades, the area under oil palm has almost tripled and its production more than quadrupled. This development is mainly attributed to the rising demand for vegetable oils and biofuels, favorable government policies in producer countries, as well as oil palm's superior production potential and profitability compared to alternative land uses. Over $85 \%$ of the world's palm oil production originates from Indonesia and Malaysia, which offer favorable agro-ecological growing conditions with relative abundance of cultivable land and agricultural labor. While the early expansion of oil palm was mainly driven by large scale private sector plantations, the more recent expansion of oil palm is largely driven by smallholder farmers. The first oil palm smallholders participated in government-supported out-grower schemes. Whereas such schemes still exist, most of the oil palm growth among smallholders is now due to independent adoption. At present, smallholders account for $41 \%$ of the total oil palm area and for $36 \%$ of the total fresh fruit bunch (FFB) production in Indonesia. If current trends continue, smallholders are expected to dominate the Indonesian palm oil sector in the near future.

Potentially, oil palm can act as an instrument to include the rural poor into the modern agricultural sector, foster rural socio-economic development and contribute to the reduction of poverty and malnutrition. Its agronomic properties and high yield potential might help to secure an environmentally sustainable supply of vegetable oils and biofuels to growing global markets. However, oil palm expansion also entails socioeconomic and environmental threats. Socio-economic threats include an increasing vulnerability and economic marginalization of the rural population, unequally distributed economic benefits among adopters, as well as negative impacts on food availability and food security. The ecological drawbacks related to oil palm expansion are deforestation, biodiversity loss, greenhouse gas emissions, and environmental degradation. Moreover, 
smallholders face a set of agronomic and institutional constraints that hinder them to achieve the crop's full production potential.

In order to design policies that enhance the environmental and economic sustainability of the diffusion of oil palm within smallholder agriculture, it is of paramount importance to i) understand the factors that influence smallholder land use decisions in general, and their decision to adopt oil palm in particular; ii) disentangle the welfare and nutritional implications that are associated with oil palm related land use changes; and iii) minimize the agronomic limitations and foster smallholder yields in existing oil palm production systems. However, the empirical evidence related to the diffusion of palm plantations into smallholder agriculture, its socio-economic implications as well as limitations in smallholder management practices is scarce.

The present study addresses this gap in the literature by analyzing farmhousehold survey data from Jambi Province, Sumatra with regard to the above mentioned objectives. In particular, we set up a duration model to analyze the process of oil palm adoption and adoption determinants in a smallholder context. Using econometric models and a set of quantile regressions, we further quantify the implications of oil palm cultivation on smallholder livelihoods, with a focus on household consumption expenditure, calorie consumption and dietary quality. Based on crop modelling and plot level input-output data, we quantify smallholder yield gaps relative to simulated potential and exploitable yields and identify the major agronomic and institutional constraints in smallholder oil palm production.

Our results highlight the fact the speed of adoption is significantly enhanced in villages that have contractual ties to private sector palm oil companies. Even though not all oil palm growers are included in such contracts, the existence of a contract in a village ensures access to processing facilities, which is a crucial factor in oil palm cultivation since FFB have to be milled within 48 hours after harvest. Thus, oil palm adoption potentially follows a regional path-dependency with regions where the oil palm industry was developed early on also being those regions where independent oil palm adoption now occurs most widely. This path-dependency has a potential downside, as it may 
foster regional disparities. However, there is also a positive side, because land use change becomes more predictable and easier to control for public policymakers. The environmental sustainability of future oil palm expansion therefore depends on the government's ability to demark land for plantation development that is already degraded, so to spare primary forest areas from direct encroachment.

Analysing the welfare implications of oil palm cultivation shows that oil palm is a financially lucrative land use option for smallholder farmers. Results suggest that its cultivation is associated with increases in household consumption expenditure, calorie consumption and dietary quality. The observed effects can mainly be attributed to farm size expansions and increases in off-farm income opportunities that are achieved with the adoption of oil palm and the labor-saving management of the crop. Consequently, the net livelihood outcomes of oil palm adoption are likely to depend on smallholder household attributes which define their ability to expand their farms and diversify their off-farm incomes. Our results support this notion, showing that oil palm adoption has heterogeneous effects especially with respect to non-food expenditures. Thus, diffusion of oil palm among smallholder farmers may worsen social inequality. From a rural development perspective, oil palm expansion might ultimately become a race for land, which might become a speculative object and a scare resource. Especially more traditional land use practices, such as slash and burn farming or rubber agro-forests, might gradually be replaced with the diffusion of oil palm plantations into smallholder agriculture. Especially in regions that are still dominated by extensive land use practices, the land rent of agriculture relative to extensive agriculture (e.g., rubber agroforests) and forests could be increased, enhancing the encroachment of forests.

Assessing the agronomic performance of oil palm adopters, we find smallholder yields to show large variations and to be generally far below plantation sector standards. In particular, existing oil palm smallholdings offer a tremendous potential for future yield increases, as they obtain only $56 \%$ of the cumulative exploitable yields over a 20 year plantation life cycle. The most important determinants of yield gaps are management practices such as fertilizer dosage and length of harvesting intervals. Furthermore, 
smallholders (formerly) operating under contract arrangements with private or government companies achieve higher yields compared to independent smallholders. Yield increases in oil palm production can help to improve the livelihoods of small scale farmers and may also reduce the conversion of forest and peat lands into oil palm plantations.

Reconciling food security and rural development with the sustainable use of the global environmental resource base has widely been identified as one of the major challenges of present times. If implemented well, smallholder oil palm cultivation offers the necessary features to minimize the inherent economic-ecological tradeoff of agricultural production. 


\section{ZUSAMMENFASSUNG}

Unter allen landwirtschaftlichen Nutzpflanzen ist der Ölpalmanbau eine der am schnellsten expandierenden Landnutzungsformen in den feuchten Tropen. Während der letzten zwei Jahrzehnte hat sich die Ölpalmanbaufläche fast verdreifacht, während die sich Produktion von Palmöl mehr als vervierfacht hat. Diese Entwicklung ist größtenteils auf eine steigende Nachfrage nach Pflanzenöl und Biodiesel, politscher Förderung des Ölpalmanbaus in produzierenden Ländern, sowie dem überlegenen Ertragspotential und einer höheren Profitabilität des Ölpalmanbaus im Vergleich zu alternativen Pflanzenölen zurückzuführen. Über $85 \%$ des weltweit produzierten Palmöls stammt aus Indonesien und Malaysia, die günstige agronomische und ökologische Anbaubedingungen bieten, sowie über relativ ausgedehnte Landflächen und ein großes Reservoir an Arbeitskräften verfügen. Während vor allem die frühe Expansionsphase des Ölpalmanbaus auf finanzstarke private Investoren zurückgeht, ist die heutige Ausdehnung der Pflanze zunehmend von Kleinbauern geprägt. Die ersten Kleinbauern innerhalb des Ölpalmsektors operierten in verschiedenen Formen von meist staatlich unterstütztem Vertragsanbau. Diese Form des Anbaus existiert zwar noch immer, die heutige Verbreitung des Ölpalmanbaus innerhalb des Kleinbauernsektors geht aber weitgehend auf unabhängig operierende Bauern zurück. So stellen Kleinbauern heute bereits $41 \%$ der Anbaufläche Indonesiens, sowie rund 36\% des produzierten Palmöls. Sollten die sich Entwicklungen der jüngeren Jahre fortsetzen, werden Kleinbauern bald den indonesischen Palmölsektor dominieren.

Der Ölpalmanbau kann vor allem wirtschaftlich schwache Kleinbauern in ländlichen Gebieten den Zugang zur modernen Landwirtschaft erleichtern, die allgemeinen ländliche Entwicklung fördern, sowie zur Armutsreduzierung beitragen. Die agronomischen Eigenschaften und das hohe Ertragspotential der Palme könnten außerdem eine nachhaltige Produktion von Pflanzenöl und Biodiesel für globale Märkte sicherstellen. Allerdings birgt eine großflächige Ausbreitung des Ölpalmanbaus auch 
erhebliche sozio-ökonomische und ökologische Risiken. Sozio-ökonomische Risiken beinhalten eine erhöhte wirtschaftliche Verwundbarkeit und Marginalisierung von Kleinbauern, ungleich verteilte Gewinne des Ölpalmanbaus innerhalb der Bevölkerung, sowie negative Auswirkungen auf die Produktion von Nahrungsmitteln und auf die Ernährungssicherheit der gesamten Bevölkerung. Ökologische Risiken der Ölpalmexpansion umfassen Entwaldung, Verlust von Biodiversität, steigende Emissionen von Treibhausgasen, sowie die Degradierung von Ökosystemen. Des Weiteren erschweren die agronomischen Anforderungen des Ölpalmanbaus, sowie dessen institutionelle Rahmenbedingungen Kleinbauern die Ausschöpfung des vollen Ertragspotentials.

Um den Ölpalmanbau im Kleinbauernsektor ökologisch und ökonomisch möglichst nachhaltig zu gestalten, ist es für politische Entscheidungsträger von herausragender Bedeutung i) Landnutzungsentscheidungen von Kleinbauern, insbesondere deren Entscheidung zur Aufnahme des Ölpalmanbaus zu verstehen; ii) die ökonomischen Auswirkungen des Ölpalmanbaus, sowie dessen Einfluss auf die Ernährungssituation adaptierende Haushalte zu kennen; iii) die agronomischen Einschränkungen der Kleinbauern zu minimieren und deren Ertragsniveau zu erhöhen. Empirische Studien, die sich mit der Verbreitung von Ölpalmen, dessen sozioökonomische Auswirkungen und agronomische Hindernissen im Kleinbauernsektor beschäftigen sind jedoch selten.

Die vorliegende Dissertation bereichert die wissenschaftliche Literatur in dem sie auf Umfragen basierende Daten landwirtschaftlicher Haushalte aus der indonesischen Provinz Jambi auf Sumatra im Hinblick auf die oben genannten Fragestellungen analysiert. Um den Prozess der Aufnahme des Ölpalmanbaus im Kleinbauernsektor nachzuvollziehen, wird ein Verweildauermodell geschätzt. Des Weiteren werden die Auswirkungen des Ölpalmanbaus auf die Lebensgrundlage ländlicher Kleinbauern Anhand ökonometrischer Modelle quantifiziert. Ein besonderer Fokus liegt hierbei auf den Ausgaben für Nahrungsmittel- und Nicht-Nahrungsmittel, dem Konsum von Kalorien, sowie der Ernährungszusammensetzung. Die Ertragslücken von Kleinbauern 
werden mithilfe von Simulations-Modellen und Produktionsdaten quantifiziert, sowie die agronomischen und institutionellen Beschränkungen im Ölpalmanbau identifiziert.

Unsere Ergebnisse zeigen dass sich der Ölpalmanbau am schnellsten in Dörfern ausbreitet, die vertragliche Bindungen zu privaten Ölpalmunternehmen haben. Obwohl in der Regel nicht alle Haushalte eines Dorfes Teil eines solchen Vertrages sind, garantiert die Existenz eines Vertragspartners dem Dorf den Zugang zu Ölpalmmühlen. Diese sind enorm wichtig, da geerntete Ölfrüchte innerhalb von 48 Stunden nach Ernte verarbeitet werden müssen, um ein Verderben der in der Frucht enthaltenen Fettsäuren zu verhindern. Daher ist die Verbreitung des Ölpalmanbaus möglicherweise pfadabhängig. Regionen in denen die Ölpalmindustrie mit ihren Weiterverarbeitungsanlagen früh entwickelt war, sind ebenso die Regionen in denen unabhängige ÖlpalmKleinbauern heute am häufigsten zu finden sind. Diese Pfad-Abhängigkeit birgt die Gefahr sich verstärkender regionaler wirtschaftlicher Unterschiede. Gleichzeitig können aber auch Landnutzungsänderungen hin zu Ölpalme besser vorhergesagt, politisch kontrolliert und somit überwacht werden. Die ökologische Nachhaltigkeit der zukünftigen Verbreitung des Ölpalmanbaus hängt davon ab, in wie fern die indonesische Regierung in der Lage ist Waldflächen von der Entwicklung von Ölpalmplantagen auszunehmen und nur solches Land freizugeben, welches bereits in gewissem Maße ökologisch degradiert ist.

Eine Analyse der ökonomischen Auswirkungen des Ölpalmanbaus zeigt, dass dieser eine finanziell lukrative Landnutzungsoption für Kleinbauern darstellt. Unsere Ergebnisse verdeutlichen, dass der Anbau von Ölpalmen mit erhöhten KonsumAusgaben, einer höheren Verfügbarkeit von Kalorien, sowie einer verbesserten Zusammensetzung der Ernährung assoziiert ist. Die beobachteten Effekte können hauptsächlich auf die Ausdehnung der Gesamtanbaufläche, sowie der Erhöhung von außerbetrieblichem Einkommen zurückgeführt werden. Dies wird adaptierenden Haushalten möglich, da die Ölpalmproduktion im Vergleich zu alternativen Landnutzung (insbesondere Naturkautschuk) einen verminderten Einsatz von Arbeitskraft erfordert. Die Wohlfahrts- und Ernährungseffekte des Ölpalmanbaus hängen daher maßgeblich 
von solchen Haushaltseigenschaften ab, die den Grad der möglichen Betriebsvergrößerung (v.a. Zugang zu Land und Kapital), sowie die Höhe des außerbetrieblich erzielten Einkommens bestimmen. Unsere Ergebnisse unterstützen diese Ansicht. So hat der Ölpalmanbau innerhalb der Gruppe adaptierender Haushalte heterogene Effekte, besonders im Hinblick auf den Konsum von Nicht-Nahrungsmitteln (u.a. Gesundheits- und Bildungsausgaben). Die Diffusion des Ölpalmanbaus im Kleinbauernsektor trägt daher potentiell zu sozialer Ungleichheit bei. Aus der Perspektive ländlicher Entwicklung, könnte die Expansion des Ölpalmanbaus zu einem Rennen um Land werden. Dieses könnte zum Spekulationsobjekt und zur knappen Ressource verkommen. Besonders traditionellere Landnutzungspraktiken wie die extensive Produktion von Kautschuk könnten durch die Ausbreitung von Ölpalmplantagen verdrängt werden. Somit könnte, besonders in von extensiver Landwirtschaft geprägten Regionen, die erhöhte Wirtschaftlichkeit des Ölpalmanbaus im Vergleich zu extensiven Praktiken zur steigenden Entwaldung führen.

Unter den beobachteten Kleinbauern variiert die agronomische Bewirtschaftung der Ölpalmfelder sehr stark. So liegen die erzielten Erträge generell weit unter dem Ertragsniveau des Privatsektors. Die von Kleinbauern bewirtschafteten Flächen erreichen nur rund 56\% des agronomisch erzielbaren Ertrages über einen 20 Jahres Plantagenzyklus und verfügen daher über ein enormes Potential zur Ertragssteigerung. Die Höhe der Ertragslücken wird vor allem von einzelnen Bewirtschaftungspraktiken wie der Düngemitteldosierung und der Länge zwischen den Ernteintervallen bestimmt. Des Weiteren erzielen (ehemalige) Vertrags-Bauern höhere Erträge im Vergleich zu unabhängig operierenden Ölpalmbauern. Eine Steigerung des Ertragsniveaus auf vorhandenen Ölpalmfeldern könnte einerseits zur Verbesserung der Einkommen adaptierender Haushalte führen, andererseits könnte der Druck auf vorhandene Waldflächen reduziert werden.

Die Vereinbarung von Ernährungssicherung und ländlicher Entwicklung mit der nachhaltigen Nutzung ökologischer Ressourcen ist eine der größten Herausforderungen unserer Zeit. Der Anbau von Ölpalmen hat das Potential die ökonomische Entwicklung 
von Kleinbauern und ländlichen Regionen zu fördern und dabei vergleichsweise geringe ökologische Kosten zu verursachen. 


\section{ACKNOWLEDGEMENTS}

Completing this dissertation was possible thanks to the continuous academic, financial and moral support from a great number of people. In first place, I would like to thank my supervisor Prof. Qaim for his guidance and advice during the entire process of my PhD and for giving me the opportunity to return to Göttingen and be part of his research group. I also want to thank Prof. Brümmer and Prof. Klasen for their time and effort in the examination of this thesis.

I further want to thank Vijesh Krishna for his outstanding support, feedback and advice during countless discussions in Göttingen and during field work in Indonesia. Makasih bang! I am also very thankful to Stefan Schwarze for his valuable input to this thesis.

I would like to thank our CRC- C07 research partners from Indonesia, including Prof. Hermanto and Heni Hasanah from Bogor IPB, and Zakky Fathoni from Jambi University for supporting and orienting us during field work in Indonesia. I also want to thank our enumerator team in Jambi including Faisal, Juarez, Sarah, Nila, Obee, Andi, Fauzi, Ima, the Dedi's (S. and R.), Habibie and Angga for a great field experience and for making hatiku senang, despite being far from home. I am still impressed with the kindness and hospitality of numerous farmers, village heads and staff members at all the places we have visited in Jambi province. Makasih banyak! The financial support of the Deutsche Forschungsgesellschaft is greatly acknowledged.

I also am very grateful for the time I could spend with my fellow CRC colleagues in Bogor, Jambi and in Göttingen. Thank you guys for your moral support and for making life in Göttingen a lot more enjoyable! I further want to thank my current and former Chair colleagues Wilhelm Klümper, Marcel Gatto, Stefan Koppmair, Theda Gödecke, Kenneth Sibiko, Priscilla Wainaina, Kibrom Sibhatu, Elijah Muange and Ilona Höpfner for sharing their experience and advice. 
Ein herzliches Dankeschön an meine ganze Familie für die immerwährende moralische Unterstützung und den festen Glauben an ein glückliches Ende. Vielen Dank an alle Freunde, die mich während dieser Zeit unterstützt haben, insbesondere an Team Pferd für die stets aufmunternden Worte, sowie die herrlichen Auswärtsfahrten.

Muchas gracias a mi familia Boliviana por su buena fé, su cariño y su apoyo que me han dado durante todo este tiempo a traves de la distancia! Y por fin, muchas gracias a mi esposa Jeannette por haberme aguantado durante esa etapa de mi vida, por compatir momentos dificiles y por su profundo amor. 


\section{TABLE OF CONTENTS}

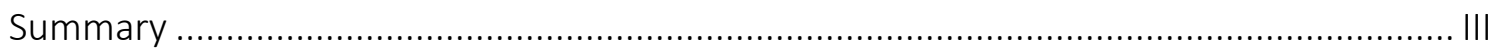

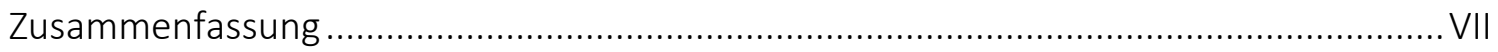

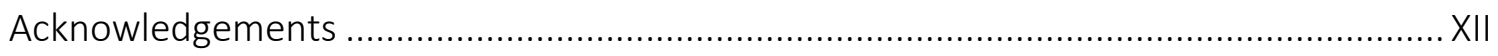

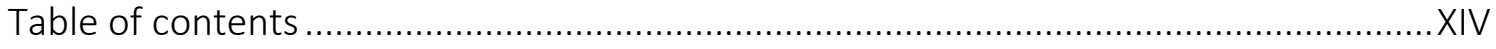

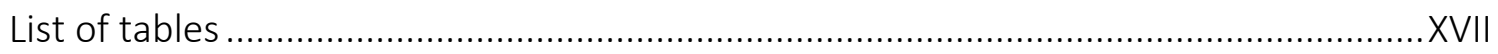

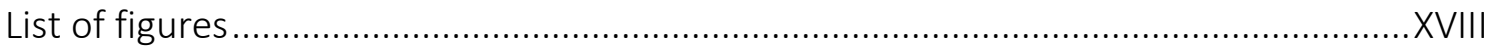

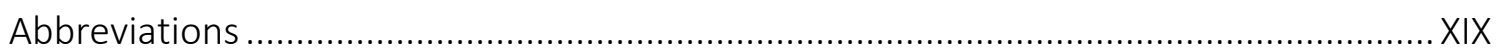

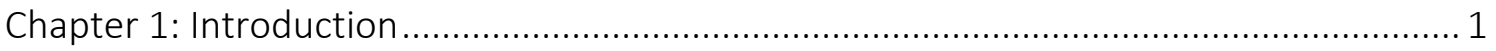

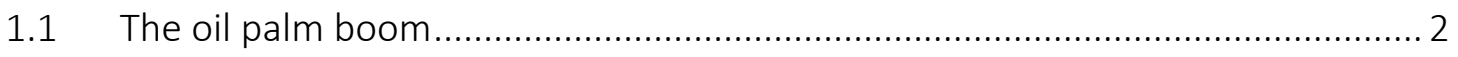

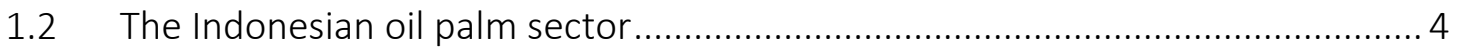

1.3 The emergence of oil palm smallholders ..................................................... 5

1.4 Problem statement and study objectives ............................................... 6

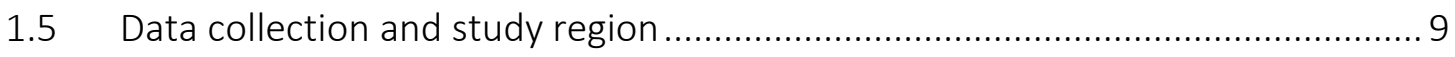

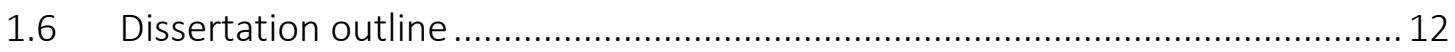

Chapter 2: Oil palm expansion among smallholder farmers ........................................ 13

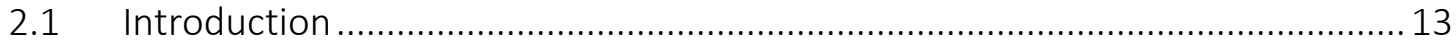

2.2 Oil palm expansion and the role of smallholders .......................................... 15

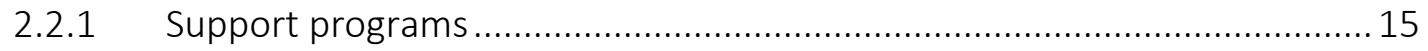

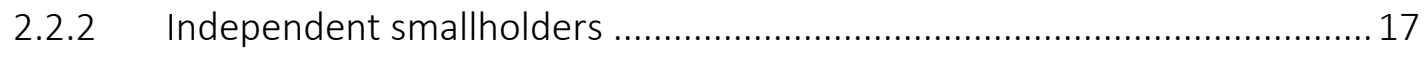

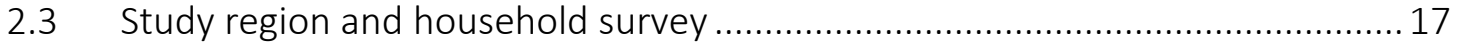

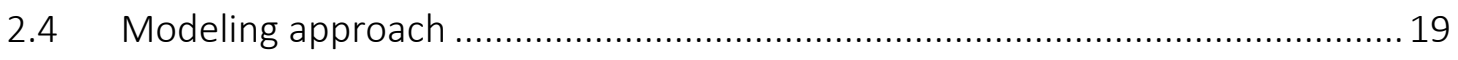

2.4.1 Background on duration models............................................................ 19

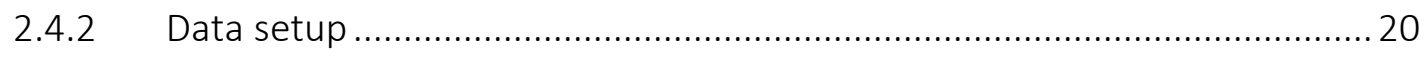

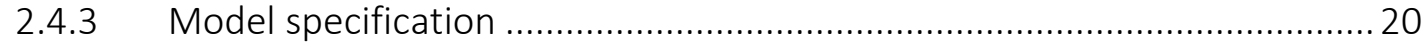

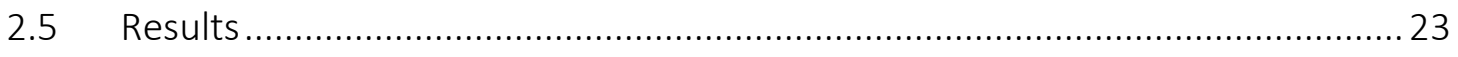

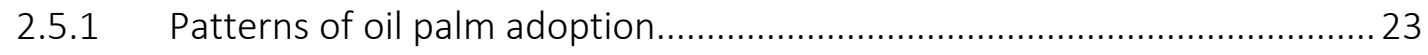




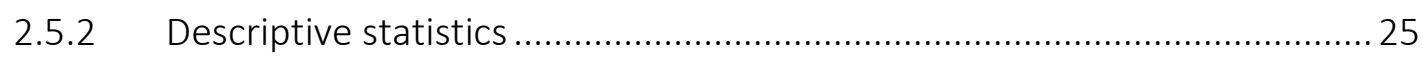

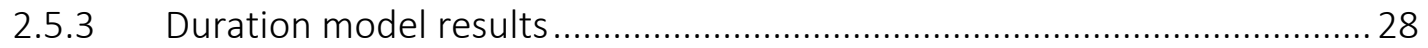

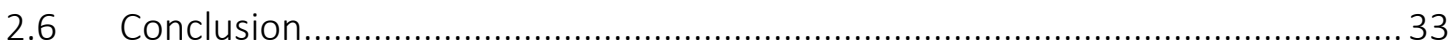

Chapter 3: Livelihood impacts of oil palm expansion among smallholders ...................... 36

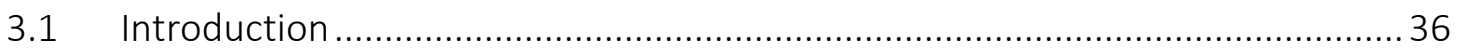

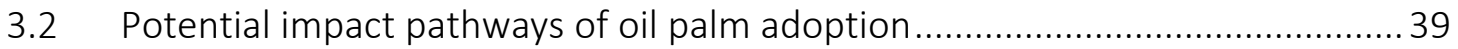

3.3 Data base, sample characteristics and land use profitability ........................... 41

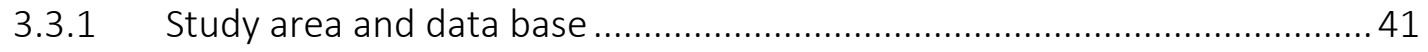

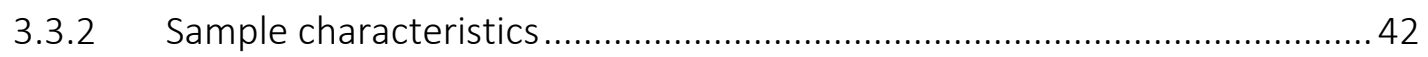

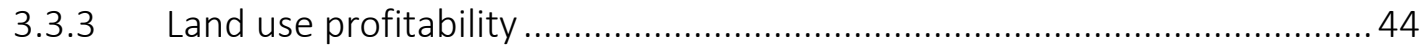

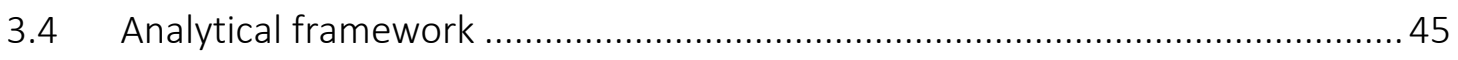

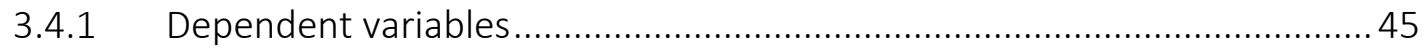

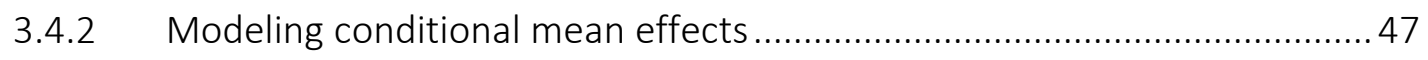

3.4.3 Quantile regressions model specification ................................................ 49

3.4.4 Addressing self-selection bias with oil palm adoption..............................50

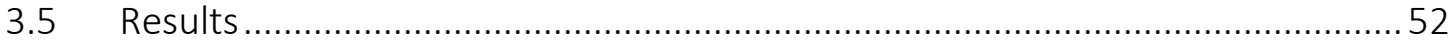

3.5.1 Effects of oil palm adoption on household income and consumption .......52

3.5.2 Impact heterogeneity among adopters .................................................. 56

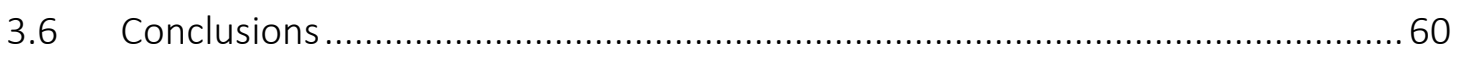

Chapter 4: Exploring yield gaps in smallholder oil palm production systems ..................62 62

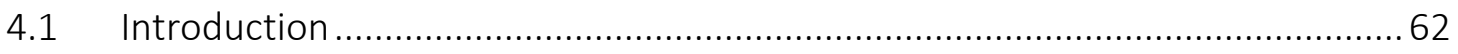

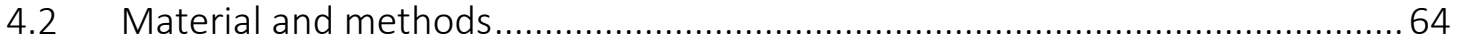

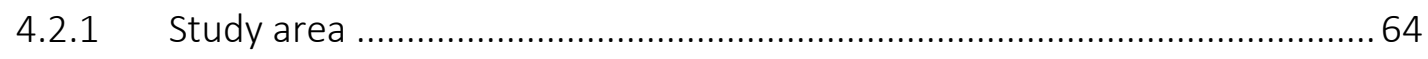

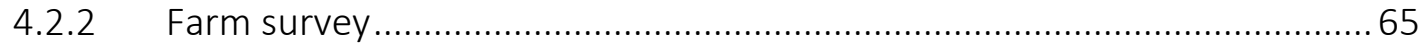

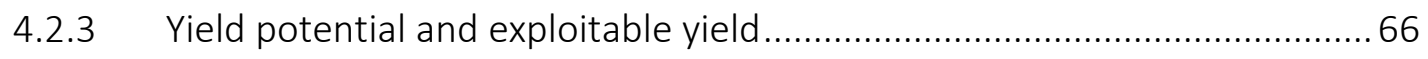

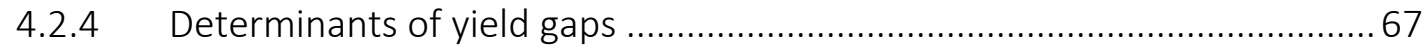

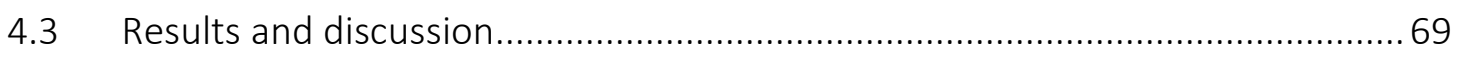

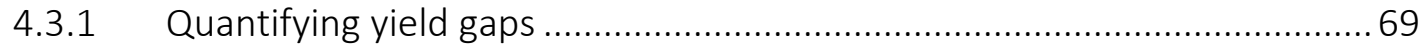

4.3.2 Determinants of smallholder yield gaps .................................................... 72

4.3.3 Characteristics of supported and independent oil palm farmers .............. 75 


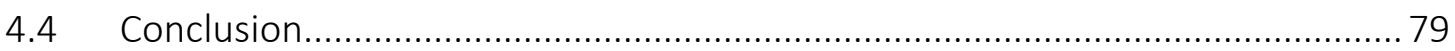

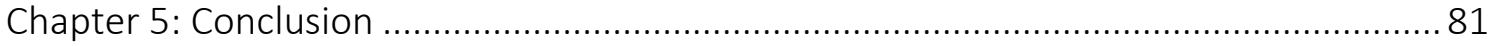

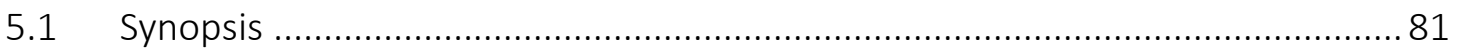

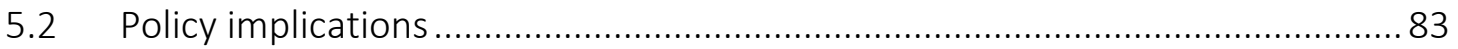

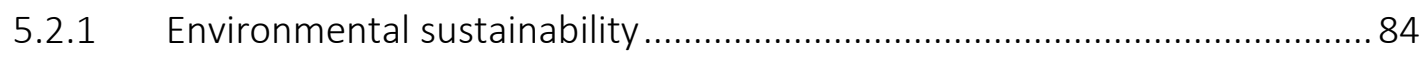

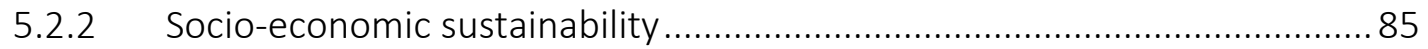

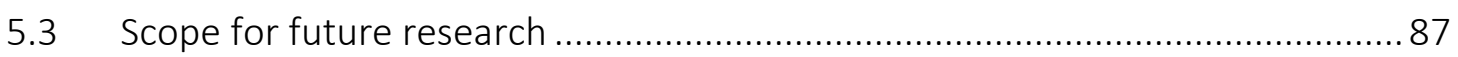

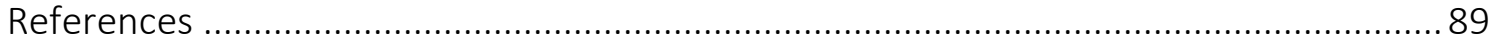

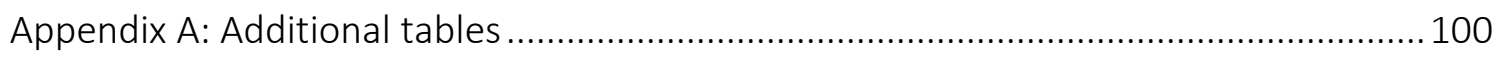

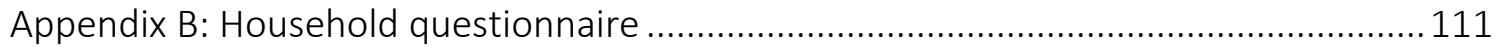




\section{LIST OF TABLES}

Table 2.1. Descriptive statistics by adoption and migration status

Table 2.2. Estimation results of duration model.

Table 3.1. Descriptive statistics for oil palm adopters and non-adopters.

Table 3.2. Annual labor use and returns to labor for oil palm and rubber plantations. ... 45

Table 3.3. Descriptive statistics for household consumption expenditure and calorie consumption by adoption status

Table 3.4. Estimation results of OLS regressions for household consumption expenditure and calorie consumption.

Table 3.5. Estimation results of OLS regressions for household consumption expenditure and calorie consumption with alternative model specifications. 56

Table 3.6. Wald-test for equality of conditional slope parameters across quantiles 60

Table 4.1. Definitions and descriptive statistics for variables used in the yield gap model.

Table 4.2. Determinants of yield gaps.

Table 4.3. Farm, plot, and management characteristics of independent and supported smallholders.

Table 4.4. Revenues, costs and gross margins of oil palm production for independent and supported smallholders.

Table 4.5. Output marketing details for independent and supported smallholders 79 


\section{LIST OF FIGURES}

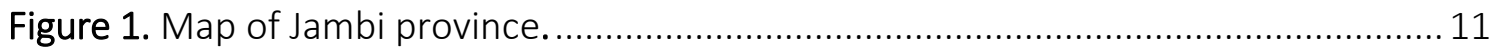

Figure 2.1. Area under oil palm in Indonesia by type of producer................................ 23

Figure 2.2 Cumulative frequency of oil palm adoption by type of adoption and migration background. 24

Figure 2.3. Share of independent oil palm adopters by regency. ................................. 25

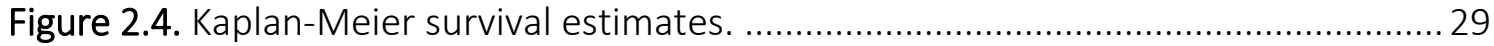

Figure 3.1. Annual gross margins for oil palm and rubber plantations over plantation age.

Figure 3.2. Quantile regression estimates for household consumption expenditure and calorie consumption. 58

Figure 4.1. Potential, exploitable and smallholder FFB yields over a 25 year plantation life cycle. 70

Figure 4.2. Cumulative potential, exploitable and smallholder yields along with exploitable yield gaps of smallholder farmers over a 20 year plantation life cycle...... 71

Figure 4.3. Gross margins of supported and independent smallholders over different plantation ages. 


\section{ABBREVIATIONS}

\begin{tabular}{ll} 
AE & Adult equivalent \\
BMKG & Indonesian Agency for Meteorology, Climatology and Geophysics \\
BPS & Statistical Office Indonesia \\
CPO & Crude Palm Oil \\
CRC & Collaborative Research Center \\
DKP & Food Security Council Indonesia \\
FAO & Food and Agriculture Organization of the United Nations \\
FAOSTAT & Statistics Division of the Food and Agriculture Organization of the United \\
& Nations \\
FFB & Fresh Fruit Bunches \\
IDR & Indonesian Rupiah \\
ISPOC & Indonesian Sustainable Palm Oil System \\
KCal & Kilo calorie \\
KKPA & Members' Primary Credit Co-operative \\
MPW & Ministry for People's Welfare Indonesia \\
NES & Nucleus Estate and Smallholder scheme \\
OECD & Organization for Economic Co-operation and Development \\
OLS & Ordinary least squares \\
PODES & Village Potential Statistics Survey Indonesia \\
USPO & Roundtable on Sustainable Palm Oil \\
USDA & United States Department of Agriculture \\
\hline
\end{tabular}




\section{CHAPTER 1: INTRODUCTION}

Agriculture sustains the nutritional demand for over 7 billion people and forms an important source of livelihoods for rural households across the developing world, playing a key role in the reduction of poverty and the eradication of hunger (FAO et al., 2014; Wheeler and Braun, 2013; World Bank, 2008). The current production of agricultural commodities relies on a large share of the world's terrestrial ecosystem and freshwater resources (Laurence et al., 2014; Foley et al., 2005; Tilman et al., 2001) and is often associated negative environmental externalities, including forest encroachment, biodiversity erosion, land degradation, and rising greenhouse gas emissions (Margono et al., 2014; Garnett et al., 2013; Kastner et al., 2012; Kitzes et al., 2008; Tilman et al., 2001). Alongside the increasing global population, changes in food consumption patterns, international trade, and urbanization push the demand for agricultural products upward, adding significant pressure on the global resource base (Garnett et al., 2013; OECD and FAO, 2011; World Bank, 2008). The resilience of the global food supply system is further threatened by the causes of climate change which are expected to lower the productive potential of existing cropland and to increase the risks that are associated with agricultural production (Wheeler and Braun, 2013; World Food Programme, 2009).

Productivity gains realized during the Green Revolution era have alleviated the resource depletion that is associated to the supply of food and agricultural products to a great extent (Pingali, 2012; World Bank, 2008). By enhancing the productive capacity of agricultural systems, millions of hectares of natural ecosystems have been saved from being transformed and brought under cultivation (Stevenson et al., 2013). However, yield growth rates for major cereals such as rice, maize and wheat have been declining since the 1980's and future yield gains are likely to be harder to achieve (World Bank, 2008). Hence, in order to secure an adequate supply of food, the expansion of the agricultural frontier seems inevitable. 
Over $80 \%$ of newly established agricultural areas between 1980 and 2000 came at the expense of intact or disturbed tropical rainforests (Gibbs et al., 2010.) The future expansion of cropland is expected to occur primarily at the frontier of remaining forests of tropical countries (Koh and Lee, 2012; Lambin and Meyfroidt, 2011; Gibbs et al., 2010; Tilman et al., 2001). These projected changes are expected to have dramatic impacts on the diversity of ecosystems around the world and on their ability to provide vital ecosystem services that are necessary to sustain the production of agricultural commodities and rural livelihoods (Foley et al., 2005; Tilman, 1999).

Small-scale farms are especially vulnerable to the depletion of ecosystems and the impacts of climate change as they rely on a limited resource base in order to sustain their livelihoods (FAO, 2014), and often lack the capacity to develop coping strategies in a changing environment (Morton, 2007). The human dimension of agricultural induced land use changes therefore deserves special attention from scholars and policy makers. Against this background, expanding the production of agricultural commodities and preserving agriculture's socio-economic functions, while ensuring the sustainable use of the global environmental resource-base has widely been identified as one of the major challenges of present times (Laurence et al., 2014; West et al., 2014; Garnett et al., 2013; Kastner et al., 2012; Lambin and Meyfroidt, 2011; Godfray et al., 2010; Kitzes et al., 2008; von Braun, 2007; Tilman et al., 2001; Tilman, 1999).

\subsection{The OIL PALM BOOM}

A rapid increase in the number of middle-income households and associated dietary changes - including an increasing consumption of resource intensive, high value food products such as animal protein and vegetable oils - are gradually becoming the major drivers of land use changes in the near future (Kastner et al., 2012; OECD and FAO, 2011; Godfray et al., 2010; Kearney, 2010; World Bank, 2008; Gerbens-Leenes and Nonhebel, 2002 and 2004). A typical case of such a transformation is the expansion of oil palm (Elaeis guineensis), for which large areas of tropical forests are converted into agricultural plantations. Over the past 100 years, oil palm has come from being a subsistence crop of West and Central Africa to the world's most produced and traded 
vegetable oil (FAOSTAT, 2014; Sayer et al., 2012; Murphy, 2007). Since 1990, the global area under oil palm plantations has almost tripled (from 6 million to almost 18 million hectares), while the production of Crude Palm Oil (CPO) has more than quadrupled (from 13 million to almost 54 million tons) (FAOSTAT, 2014). Especially during its initial diffusion, oil palm was perceived as a social and environmental panacea, which could offer economic wealth and rural development opportunities to producer countries while supplying the global economy with a renewable and carbon neutral source of energy (Gilbert, 2012; Sheil et al., 2009). These expectations were mainly attributed to the crops' superior yield potential and several advantages related to its agronomic management compared to alternative land uses, as listed below.

First, depending on the respective management intensity and agro-ecological growing conditions, oil palm is able to yield 3-10 times more oil per hectare compared to alternative oil crops (Carter et al., 2007; Murphy, 2007; Wahid et al., 2005; Corley and Tinker, 2003), making it one of the most profitable land use system throughout the humid tropics (Sayer et al., 2012). ${ }^{1}$ Second, in contrast to annual oil crops which are only grown during a determined season of the year, oil palm is evergreen with a high leaf area index allowing an efficient interception of incoming solar radiation and the production of biomass and fresh fruit bunches (FFB) during the entire year (Wahid et al., 2005; Corley and Tinker, 2003). Third, FFB can be harvested continuously up to plantation ages of 25 to 30 years without the need of repetitive land preparation and sowing (Basiron, 2007; Carter et al., 2007). Fourth, due to its perennial nature, oil palms develop a deep and complex rooting system which enables the plant to take up nutrients and water more efficiently compared to annual crops (Wahid et al., 2005; Corley and Tinker, 2003). Fifth, oil palm produces two different types of oils- palm oil from the flesh or mesocarp of the fruit and palm kernel oil from the fruit's seed or endosperm (Corley and Tinker, 2003). Both oils differ with respect to their composition of fatty acids, making them usable in manifold products in the food and non-food sector

\footnotetext{
${ }^{1}$ Oil palm develops best within 10 degrees of the equator, requires 2000 to 5000 millimeters of evenly distributed annual rainfall, above 2000 hours of sunshine and should be grown below 600 meters above sea level (Corley and Tinker, 2003).
} 
(Basiron, 2007; Sheil et al., 2009; Wahid et al., 2005). ${ }^{2}$ Sixth, oil palm is cultivated most efficiently in large scale plantations. ${ }^{3}$ Thus, oil palm mills- which are necessary to process harvested FFB to avoid oil the decay of fatty acids- and plantations can be designed to meet each other's needs (Corley and Tinker, 2003).

\subsection{THE INDONESIAN OIL PALM SECTOR}

Over $85 \%$ of the present world's palm oil production originates from Indonesia and Malaysia, which offer favorable agro-ecological growing conditions, vast strips of uncultivated land and a large and cheap labor force (McCarthy and Cramb, 2009; Basiron, 2007). Since 1990, Indonesia increased its area under oil palm plantations and annual CPO production more than ten-fold and passed Malaysia in 2008 to become the world's largest producer of palm oil (FAOSTAT, 2014).

The Indonesian government has used oil palm cultivation as a vehicle to foster rural development and economic growth (McCarthy, 2010; McCarthy and Cramb, 2009; Zen et al., 2006). Supplementary to the growing demand for vegetable oils in global markets, policy makers passed favorable land laws and promoted foreign investment into large-scale plantation development (McCarthy and Cramb, 2009; Basiron, 2002). The creation of an oil palm based agro-industry was seen as an important means to transform Indonesia's environmental and human resources into a pillar of national economic development and a provider of foreign exchange earnings (Cramb and Curry, 2012; Sayer et al., 2012; McCarthy, 2010; Feintrenie et al., 2010).

Under the New Order regime of president Suharto (1967-1998), the Indonesian state created land reserves on the outer, less populated islands of Indonesia, that were

${ }^{2}$ Oil from the mesocarp is mainly consumed as cooking oil or contained in a wide range of food items such as margarine, cookies and biscuits, palm kernel oil is mainly used in non-food products such as detergents, cosmetics, plastics, herbicides, as well as a broad range of other industrial and agricultural chemicals (Basiron, 2007; Wahid et al., 2005; Corley and Tinker, 2003). Kernel meal or cake - an additional by-product in CPO refining- is used as rich source of animal protein and marketed as animal feed (Basiron, 2007; Wahid et al., 2005).

${ }^{3}$ In particular, oil palm management does not involve labor operations that require careful and cautious execution (like e.g. pruning or harvesting of coffee shrubs), but rather demands the right timing of routine tasks (especially harvesting and fertilization), which is most efficiently secured in a large scale plantations (Corley and Tinker, 2003). 
under formal control of the national forestry apparatus (McCarthy and Cramb, 2009; McCarthy, 2000). The policy rationale was to transform rural areas into natural resource frontiers of enormous economic value (McCarthy and Cramb, 2009). After taking control of vast strips of land, the state issued timber extraction and plantation concessions to private sector companies (McCarthy, 2000).

\subsection{THE EMERGENCE OF OIL PALM SMALLHOLDERS}

From the 1980's to the early 2000's, Indonesian policy makers encouraged private sector companies to engage in contractual arrangements with smallholder farmers in the framework of so called nucleus estate and smallholder (NES) and 'Koperasi Kredit Primer untuk Anggota' (KKPA) schemes (Zen at al., 2006). In general, these schemes were different forms of public-private partnerships with the rationale to incorporate farmers into the newly emerging, modern agricultural sector (McCarthy, 2010; McCarthy and Cramb, 2009; Zen et al., 2006). Contract arrangements mainly differed with respect to the role of the state in the planning, supervision and implementation of the scheme and the source of development capital needed for the initial establishment of smallholder plantations. Funds were either granted by the Indonesian government, international donors such as the World Bank or the Asian Development Bank, or the partnering company itself (McCarthy and Cramb, 2009; Zen et al., 2006).

Contractual arrangements between farmers and companies usually entailed the following components. In return for obtaining access to land and subsidized working capital, companies were expected to develop oil palm smallholdings in the vicinity of their core plantations and provide smallholders with technical know-how and agronomic services including the supply of high quality inputs and access to output processing facilities (McCarthy and Cramb, 2009; Zen et al., 2006). Contracted or supported smallholders would typically repay the resulting debt from plantation development by the deducting a certain share from their FFB harvests to the company. Once the credit was repaid, farmers would receive formal land titles to their parcel (Zen et al., 2006). 
The Indonesian state linked supported oil palm out-grower schemes to the government trans-migration program, which involved the resettlement of families from Indonesia's over- to its under-populated islands (Sheil et al., 2009; Vermeulen and Goad, 2006; Zen et al., 2006). Through this connection policy makers reconciled national resettlement plans with agricultural development objectives: thousands of resource poor, mostly Javanese migrants were seeking their fortune on the outer islands. By joining NES schemes, trans-migrants provided the human resource base that would satisfy the requirement for labor of the emerging oil palm based agro-industry (McCarthy and Cramb, 2009).

After the end of the Suharto period in 1998 and the associated political decentralization process, state support in out-grower schemes gradually expired. The government reduced its role to that of a mere facilitator and supervisor of arrangements that were now negotiated more directly between local communities and private investors (McCarthy and Cramb, 2009; Zen et al., 2006). As a result, supported schemes lost in relative importance. Whereas supported out-grower schemes still exist, most of the oil palm growth among smallholders is now due to independently operating farmers (Feintrenie and Levang, 2009; Sheil et al., 2009). Independent smallholders adopt oil palm spontaneously without direct assistance from the private sector or the government. These sporadic adopters largely take advantage of the maturing oil palm sector and the associated infrastructural and market development (McCarthy, 2010). At present, supported and independent smallholders account for $41 \%$ of the total oil palm area and for $36 \%$ of the total FFB production in Indonesia (ISPOC, 2012). If these trends continue, smallholders are expected to dominate the Indonesian palm oil sector in the near future (BPS, 2015).

\subsection{Problem statement And StUdy objectives}

The cultivation of oil palm has the potential to foster rural socio-economic development and to contribute to the reduction of poverty and malnutrition (Cahyadi and Waibel, 2013; Sayer et al., 2012; Feintrenie et al., 2010; Rist et al., 2010). Attributed to its agronomic properties and high yield potential, it might help to secure an 
environmentally sustainable supply of vegetable oils and biofuels to growing global markets and provide producer countries with the financial resources needed to protect its forests (Gilbert, 2012; Sheil et al., 2009). However, the expansion of oil palm also entails considerable environmental and socio-economic threats.

While Indonesia made its way to become the world's largest supplier of palm oil, between 2000 and 2012 the country lost over 6 million hectares of forests. In 2012, the net annual primary forest cover loss was the largest in the world (Margono et al., 2014). The establishment of oil palm plantations has been identified as one of the key drivers of these losses, contributing to decline in biodiversity and ecosystem services, greenhouse gas emissions, and related environmental problems (Margono et al., 2014; Wilcove and Koh, 2010; Buttler and Laurence, 2009; Danielsen et al., 2009; Fitzherbert et al., 2008; Koh and Wilcove, 2008; Miyamoto, 2006).

Despite oil palm's economic relevance for national economies of producer countries, the livelihood outcomes of oil palm cultivation for adopting smallholders are not always positive (Cramb and Curry, 2012; Sayer et al., 2012; Rist et al., 2010; Sheil et al., 2009). Major threats that have been associated with oil palm agriculture include an increasing vulnerability and economic marginalization of the rural population, conflicts over land use and land ownership between private sector companies and local communities (McCarthy, 2010; Rist et al., 2010; Sheil et al., 2009), as well as unequally distributed benefits among oil palm adopters (Cahyadi and Waibel, 2013; Cramb and Curry, 2012; McCarthy, 2010). Moreover, the concentration on oil palm production has raised concerns with respect to food availability and food security (World Bank, 2007; von Braun, 1995). As malnutrition and undernourishment are still widespread in Indonesia- with $11.4 \%$ of the Indonesian population living below the national poverty line and 37.2\% of all Indonesian children being stunted in 2013 (FAO et al., 2014)- the adoption of oil palm might entail a decrease in on-farm production diversity, a declining significance of subsistence food crops, and a greater dependency on trade and markets to satisfy nutritional needs (Pellegrini and Tasciotti, 2014; Jones et al., 2014; World Bank, 2007). Oil palm adopters might lose their ability to directly access a wide variation of 
food items and increase their vulnerability to price shocks on international commodity markets, which potentially entails negative effects on household nutrition (Pellegrini and Tasciotti, 2014).

In addition, there are considerable management deficiencies in existing oil palm smallholdings. Oil palm adopters face a set of agronomic and institutional constraints that hinder the achievement of the crop's full production potential (Corvey and Tinker, 2003). Smallholder yield levels show large variations and are often far below private sector standards (World Bank, 2011; Vermeulen and Goad, 2006; Hartemik, 2005; Corley and Tinker, 2003). Production constraints include the use of poor planting material, inadequate dosage and application of fertilizers, as well as overlong harvesting cycles (Corley and Tinker, 2003).

In 2004, the private sector responded to the emerging ecological and economic challenges by creating the Roundtable on Sustainable Palm Oil (RSPO). The RSPO is a multi-stakeholder, non-profit organization that aims at promoting the sustainable production and use of palm oil. It is composed of members from the entire palm oil value chain who have committed to comply with a set of high standard principles of operation including environmental responsibility, compliance with applicable laws and regulations, as well as the application of best agronomic management practices (RSPO, 2013). ${ }^{4}$ The RSPO further entails measures to promote smallholder farmers such as capacity building and financial support. At present around $18 \%$ of the global and $20 \%$ of the Indonesian palm oil production is RSPO certified (RSPO, 2014).

Despite the growing importance of smallholders within the oil palm sector and existing supportive measures carried out by the RSPO, there is little empirical knowledge on the drivers and implications of smallholder land use changes towards oil palm. To the best of our knowledge, no study has analyzed the process of oil palm adoption and adoption determinants in a smallholder context. There is only limited empirical evidence

\footnotetext{
${ }^{4}$ Currently, the RSPO has more than 2100 members including producers, processors and traders, consumer goods manufacturers, retailers, banks and investors, as well as NonGovernmental Organizations (RSPO, 2014).
} 
on the welfare and nutritional implications of oil palm adoption (Cramb and Curry, 2012; Feintrenie et al., 2010; Rist et al., 2010) with only one study building on econometric models (Cahyadi and Waibel, 2013). While a few recent studies looked at the profitability of smallholder oil palm production in Malaysia and in Indonesia (Rahmat, 2013; Feintrenie et al., 2010; Rist et al., 2010), analysed the determinants of smallholder yields and income variations (Lee et al., 2014), performed a financial cost-benefit analysis (Belcher et al., 2004), and analysed the level of technical efficiency of smallholder oil palm farmers (Hasnah and Coelli, 2004), no study has yet quantified smallholder yield gaps and identified their determinants.

The sustainable development of oil palm agriculture implies minimizing the associated environmental externalities while maximizing its socio-economic benefits. In order to design adequate policies, it is of paramount importance to acquire knowledge on oil palm's diffusion process, its welfare implications, as well as persisting agronomic limitations in a smallholder context.

The present study contributes to the existing literature by empirically analyzing smallholder oil palm cultivation in Jambi province, Sumatra. In particular, the study has the following research objectives:

i) Analyzing the factors that influence smallholder land use decisions in general, and their decision to adopt oil palm in particular.

ii) Disentangling the welfare and nutritional implications that are associated with the adoption of oil palm.

iii) Quantifying smallholder yield gaps and identifying the agronomic limitations in existing oil palm production systems.

\subsection{DATA COLLECTION AND STUDY REGION}

The present study forms part of the Collaborative Research Center 990 (CRC 990) entitled 'Ecological and Socioeconomic Functions of Tropical Lowland Rainforest 
Transformation Systems' financed by the German Research Foundation (DFG). The study area of the CRC 990 is Jambi province, Sumatra. ${ }^{5}$

Jambi province is one of the hotspots of recent oil palm expansion. With a mean annual temperature of $27.0^{\circ} \mathrm{C}$ (years 2010-12) and mean annual precipitations of 2403 mm (BMKG, 2014), Jambi province offers favorable agro-ecological conditions for oil palm cultivation. Jambi is inhabited by around 3.26 million people with agriculture employing the main share of the working population. Among all provinces in Indonesia, Jambi ranks seventh in terms of cultivated oil palm area (over 0.72 million hectares) and sixth in terms of CPO production (around 1.70 million tons per year) (BPS, 2015).

A comprehensive household survey builds the data base of this dissertation. The selection of sample households aimed at capturing the province's regional diversity and thus followed a multi-stage random sampling approach, stratifying on the regency, district, and village levels (Faust et al., 2013). Five lowland regencies were purposively selected which represent the major shares of oil palm farmers and cultivated oil palm area. These regencies are Sarolangun, Batanghari, Muaro Jambi, Tebo, and Bungo. In a next step, four districts per regency, and two villages per district were selected randomly. Village selection was based on village lists from the Indonesian Village Potential Statistics (PODES) dataset which includes all existing villages for the given regencies. $^{6}$

Following village selection and prior to data collection itself, a complete list of households along with the main type of household occupation was developed in each of the villages. In addition, basic village-level information from the head of the village and the village secretary (e.g. number of farming households, etc.) were collected. As selected villages were found to differ significantly with respect to population size, households were selected proportionally according to village size, averaging 15 households per village and yielding a total of 600 households from the 40 randomly selected villages.

\footnotetext{
${ }^{5}$ See http://www.uni-goettingen.de/en/310995.html for additional details.

${ }^{6}$ See http://www.rand.org/labor/bps/podes.html for additional details.
} 
In addition, five villages in the region were purposively selected, to align with research activities of research partners from the CRC 990. Within these five villages, 83 households were selected randomly and an additional 18 households non-randomly. Non-random households are the owners of oil palm and rubber plots on which supplementary research activities related to the CRC 990 were carried out. In total, data from 701 households were collected. Selected villages, the type of village selection and the major type of land use are presented in Figure 1.

Data was collected between September and December 2012 through face to face interviews using structured questionnaires. Information on current and past land use of households, socio-economic household characteristics, farm endowments, plot level agricultural activities, and off-farm income sources, as well as a detailed food and non-food consumption expenditure module were gathered. ${ }^{7}$

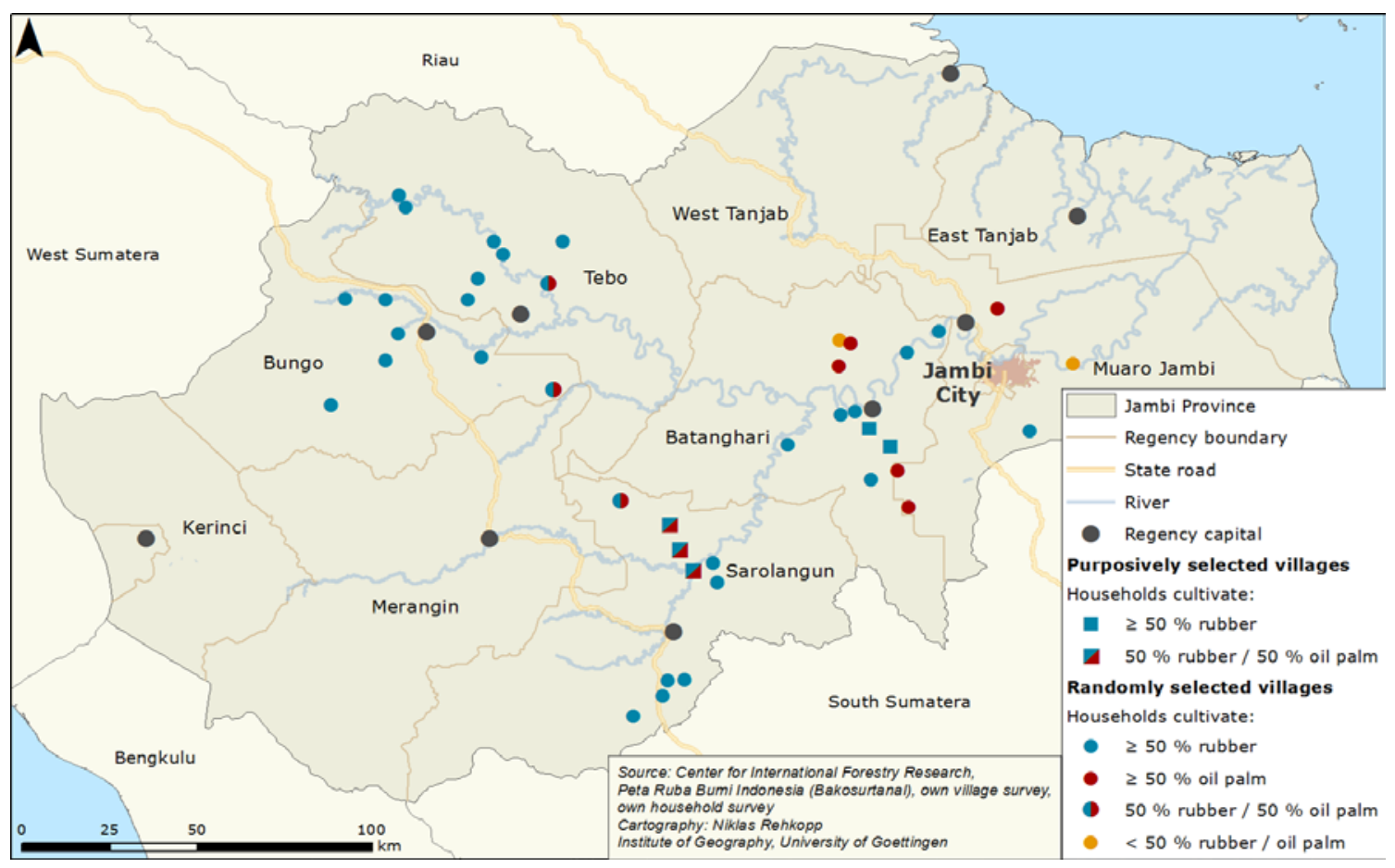

Figure 1. Map of Jambi province. Selected villages are depicted along with type of village selection and dominating land use at the village level.

${ }^{7}$ The English version of the questionnaire employed during data collection is included in Appendix B. 


\subsection{Dissertation OUTLINE}

This dissertation is organized as follows. Chapter 2 addresses the first research objective. In particular, the process of oil palm adoption and adoption determinants in a smallholder context are analyzed employing survival analysis and associated duration models. These models cannot only explain adoption decisions at one point in time, but they are suitable to explain adoption dynamics, which is of particular interest to understand the expansion of oil palm over time.

Chapter 3 tackles the second research objective by quantifying the implications of oil palm adoption on households' livelihoods. Specifically, household food and nonfood consumption expenditure, calorie consumption and dietary quality are assessed using econometric models and quantile regressions.

Chapter 4 focuses on the third research objective. Based on crop modelling and plot level input-output data, smallholder yield gaps relative to simulated potential and exploitable yields are quantified. In addition, the major agronomic and institutional constraints in smallholder oil palm production are identified.

Chapter 5 summarizes the major findings of the study, draws conclusions and derives policy implications. It further proposes some directions for future research. 


\section{CHAPTER 2: OIL PALM EXPANSION AMONG SMALLHOLDER FARMERS}

Abstract. Many tropical regions experience a rapid expansion of oil palm, causing massive land use changes and raising serious environmental and social concerns. Indonesia has recently become the largest palm oil producer worldwide. While much of the production in Indonesia comes from large-scale plantations, independently operating smallholders are increasing in importance and may dominate production in the future. In order to control the process of land use change, the micro level factors influencing smallholder decisions need to be better understood. We use data from a survey of farm households in Sumatra and a duration model to analyze the patterns and dynamics of oil palm adoption among smallholders. Initially, smallholders were primarily involved in government-supported out-grower schemes, but since the mid-1990s independently operating oil palm farmers have become much more important. In addition to farm and household characteristics, village level factors determine oil palm adoption significantly. Independent smallholders adopt oil palm especially in those villages that also have contracts and out-grower schemes, leading to a regional pathdependency of former government policies.

\subsection{INTRODUCTION}

Worldwide, the area under oil palm has almost tripled during the last 25 years (FAOSTAT, 2014). This rapid land use change has raised serious environmental and social concerns. As the expansion primarily occurs in tropical rainforest areas, a link between the establishment of new oil palm plantations and deforestation is likely, contributing to biodiversity loss, greenhouse gas emissions, and related environmental problems (Margono et al., 2014; Wilcove and Koh, 2010; Buttler and Laurence, 2009; Danielsen et al., 2009; Fitzherbert et al., 2008; Koh and Wilcove, 2008; Miyamoto, 2006). One of the hotspots of oil palm expansion and loss of tropical forest is Indonesia. Between 2000 and 2010, Indonesia expanded its oil palm area by 4 million hectares and became the 
world's largest palm oil producer (FAOSTAT, 2014). During the same period, Indonesia lost over 6 million hectares of forest (Margono et al., 2014). While not all deforestation is linked to oil palm expansion, research shows that economic factors, such as the growing international demand for palm oil and rising export price levels, as well as government policies to promote this industry play a key role in the dynamics of forest clearing in Indonesia (Wheeler et al., 2013; Rist et al., 2010; Feintrenie and Levang, 2009; Fitzherbert et al., 2008).

Many of the oil palm plantations in Indonesia were established by large companies. However, smallholder farmers are also increasingly involved, already accounting for more than $40 \%$ of the total oil palm land (Gatto et al., 2014; BPS, 2015). It is possible that smallholder farmers will dominate palm oil production in Indonesia in the future (Feintrenie and Levang, 2009). In the beginning, smallholder oil palm cultivation was encouraged and supported through specific government policies such as state led out-grower schemes (Zen et al., 2006). But such policies were phased out, so that nowadays smallholders establish and manage their oil palm plantations independently. In contrast to large-scale concessions and land use transformation through companies, these spontaneous decisions by a large number of smallholders are more difficult to monitor and control.

Designing policies that can contribute to sustainable development requires good understanding of the factors that influence smallholder land use decisions in general, and their decision to adopt oil palm in particular. While several studies have looked at impacts of oil palm adoption on smallholder livelihoods (Cahyadi and Waibel, 2013; McCarthy, 2010; Rist et al., 2010; Sheil et al., 2009; Wigena et al., 2009), we are not aware of any study that has analyzed the process of oil palm adoption and adoption determinants in a smallholder context. We address this gap in the literature, using household survey data collected in Jambi Province, Sumatra, one of the main oil palm production areas in Indonesia. For data analysis, we develop and estimate a duration model. Duration models were used previously to analyze agricultural technology adoption (Matuschke and Qaim, 2008; Abdulai and Huffman, 2005; Burton et al., 2003), 
but not with a specific focus on land use change. These models cannot only explain adoption decisions at one point in time, but they are also suitable to explain adoption dynamics (McWilliams and Zilberman, 1996), which is of particular interest to understand the expansion of oil palm over time.

The rest of this chapter is structured as follows. Section 2.2 provides some background on the introduction of oil palm to smallholder agriculture in Indonesia. In section 2.3, we describe the study region and the household survey. Section 2.4 explains the modeling approach, before the empirical results are presented and discussed in section 2.5. Section 2.6 concludes.

\subsection{OIL PALM EXPANSION AND THE ROLE OF SMALLHOLDERS}

Over the last three decades, the Indonesian government has used oil palm as a vehicle for socio-economic rural development (Zen et al., 2006). Major expansion of oil palm started in the 1980s through large-scale state-owned and later also private companies. Smallholder farmers were involved in oil palm cultivation through contractual ties with these companies under the roof of government-sponsored support programs (Gatto et al., 2014). Only after the end of the New Order regime in 1998 and the associated political decentralization process, government support programs lost in importance, giving way to a spontaneous, and less regulated process of further oil palm expansion. While contracts between companies and smallholders still exist, most of the expansion nowadays occurs independently. Hence, we can differentiate between two types of smallholders involved in oil palm cultivation. First, those who started oil palm cultivation under a government-or private sector supported out-grower scheme, and second, those who decided to adopt oil palm independently (McCarthy, 2010). Further details are provided in the following.

\subsubsection{SUPPORT PROGRAMS}

The first smallholders to start oil palm cultivation in Sumatra did so with government support through the so-called nucleus estate and smallholder (NES) schemes. NES out-grower schemes were especially prominent during the 1980s and 
1990s. Participation was often linked to government transmigration programs, involving the resettlement of families from densely populated islands, such as Java, to islands with lower population density, such as Sumatra (McCarthy and Cramb, 2009). During the mid-1990s the state withdrew from its active role in the planning and financing of out grower schemes to become a mere facilitator of private sector- community partnerships, which were known as KKPA schemes ('Koperasi Kredit Primer untuk Anggota') (McCarthy, 2010). The basic idea behind both the NES and KKPA out-grower schemes was to help smallholders overcome entry barriers to oil palm cultivation (McCarthy and Cramb, 2009).

NES and KKPA schemes are a form of partnership, where the core plantation (nucleus) managed by the state or private company is surrounded by smallholdings (Zen et al., 2006). Companies are obliged to assist a certain number of farmers with the establishment of oil palm smallholdings and the provision of credit, inputs, and technical assistance. Participating farmers will eventually receive a land title for their smallholding, after the credit received for the cost of plantation establishment has been repaid (McCarthy and Cramb, 2009; Zen et al., 2006). A main difference between NES and KKPA schemes exists in terms of the negotiation process between the actors involved and also the way in which land is acquired by the companies. In NES schemes, the state typically gives a concession to a public or private company for plantation development. In KKPA schemes, private companies still need a concession but additionally have to negotiate with local farmers over access to land (Zen et al., 2006). This is because traditional land rights are again recognized.

The main shortcoming of NES schemes was the lack of recognition of traditional land rights and tenure arrangements by the state. When granting large-scale concessions to companies, local communities were not adequately compensated, creating disputes over access to land (McCarthy, 2000). Many local communities claim back their traditional territories which were given out as plantation concessions by the state (Rist et al., 2010; Vermeulen and Goad, 2006; Zen et al., 2006). In the post-New Order period, traditional land rights received again increased recognition (Krishna et al., 
2014), so that negotiations about access and compensation is required. However, the main shortcoming of KKPA schemes is that negotiations are not always transparent and fair for all village residents. Since companies negotiate over communal land for plantation development with village elites, there are cases where less-influential village members were excluded from participation (McCarthy, 2010).

\subsubsection{INDEPENDENT SMALLHOLDERS}

While NES and KKPA schemes still exist, oil palm adoption by smallholders today occurs mainly independently, that is without any direct state involvement or control. However, not every smallholder has the ability or incentive to adopt oil palm. First, geographical location matters. As fresh fruit bunches need to be processed within 48 hours after harvesting, oil palm cultivation depends on access to the processing industry. The existence of a mill in the vicinity that is willing to purchase fruits from independent smallholders is an important location advantage for adoption. Second, the traditional alternative for oil palm cultivation in Sumatra is rubber, which has become part of the cultural identity of the autochthonous population (McCarthy, 2007). Oil palm is less labor-intensive than rubber, but more capital and input-intensive. Furthermore, oil palm cultivation requires different technical knowledge. Hence, some local farmers may be hesitant to adopt. There may also be differences between the autochthonous people and the immigrants from Java and other islands, whose cultural identity is usually less connected to rubber.

\subsection{STUDY REGION AND HOUSEHOLD SURVEY}

This study builds on data that we collected in Jambi Province, Sumatra. Among all provinces in Indonesia, Jambi ranks $6^{\text {th }}$ in terms of oil palm production and $7^{\text {th }}$ in terms of area under oil palm (approximately 721,000 ha) (BPS, 2015). Data were collected in five lowland regencies (Sarolangun, Batanghari, Muaro Jambi, Bungo, and Tebo) where most of Jambi's oil palm area and the main share of the smallholder producers are located (BPS, 2012). To capture the province's regional diversity, a multi-stage random sampling approach was followed, first sampling four districts per regency, second 
sampling two villages per district, and third sampling households per village (Faust et al., 2013). As villages were found to differ significantly in population, the number of households per village was sampled proportional to village size. We sampled a total of 600 households from the 40 randomly selected villages. In addition, five villages in the region were purposively selected, to align with other activities of research partners. Within these five villages, 83 households were selected randomly and 18 additional households non-randomly. In total, we collected data from 701 households. We control for non-randomly selected villages and households in the statistical analysis.

Data from the sampled households were collected through face-to-face interviews using structured questionnaires. The survey was conducted between September and December 2012. In particular, we collected data on current and past land use of households, farming and other economic activities, institutional conditions, and socio-demographic characteristics of household members.

Of the 701 households, 250 cultivated oil palm and 451 did not. Most of the nonadopters are involved in rubber cultivation. Of the 250 oil palm farmers, 188 had adopted oil palm independently, while the other 62 had started oil palm cultivation as part of the government's transmigration program or other supported out-grower schemes (see previous section). As explained, the government support programs lost in importance and current oil palm expansion among smallholders is mainly driven by independently operating farmers. Hence, our focus is on explaining these spontaneous adoption decisions by smallholders, which are quite different from household decisions to participate in supported out-grower schemes. For the purpose of this analysis, we exclude the 62 farmers who had started oil palm cultivation through supported initiatives. Furthermore, from the group of non-adopters, we had to exclude 24 farmers who neither grew oil palm nor rubber. The survey questionnaire was designed such that land use history was only recorded for farmers growing perennial crops. Data on past land use are required for the duration analysis. The total sample used consists of 615 farmers, encompassing 188 oil palm adopters and 427 non-adopters. 


\subsection{MOdeling APPROACH}

\subsubsection{BACKGROUND ON DURATION MODELS}

Duration models have their origin in the biomedical sciences and industrial engineering (Kiefer, 1988); they help to analyze factors that influence the probability of a certain event occurring over time. Duration models were first applied in economics by Lancaster (1979) and Nickell (1979) studying the length of unemployment spells. There are also a few recent studies that used duration models to analyze the dynamics of innovation adoption in agriculture (Schipmann and Qaim, 2010; Matuschke and Qaim, 2008; D'Emden et al., 2006; Key and Roberts, 2006; Abdulai and Huffman, 2005; Dadi et al., 2004; Burton et al., 2003; Fuglie and Kascak, 2003). Unlike conventional technology adoption models, the focus of duration analysis is not on adoption at one point in time, but on explaining the length of the non-adoption spell (or, in other words, the time to adoption). The start of a spell is when the innovation becomes available for adoption; the spell ends for a particular farmer when he/she decides to adopt. The probability of non-adoption is reflected by the hazard rate $(\lambda)$, which is the core function in duration analysis (Cleves et al., 2002).

Let $T$ be a non-negative random variable, and $t$, a realization of $T$, present the duration in a specific state (e.g., non-adoption). The hazard rate is also known as the instantaneous rate at which a spell ends at duration $T=t$, given that it has lasted until $t$. More formally:

$$
\lambda(t)=\lim _{\Delta \rightarrow 0} \frac{\operatorname{Pr}(t+\Delta t>T>t \mid T>t)}{\Delta t}
$$

The hazard rate can be interpreted as the limiting probability that the event of interest (adoption) occurs at a given point, conditional upon non-occurrence of the event until that point. We use this framework to analyze the adoption of oil palm among smallholder farmers in Jambi. 


\subsubsection{DATA SETUP}

In our study, the length of a spell indicates the time it takes a farmer to adopt oil palm. Our data is set up in a time discrete manner, where the time spell to adoption is measured in years. Each farm/household observation is presented by one to multiple rows, depending on the length of the individual adoption spell. The starting point of a spell is defined as the time when independent oil palm cultivation became possible or was first observed, which was in the mid-1990s. We set the spell start to 1995 . For farmers who began farming in their current location only after 1995 (e.g., due to migration or inheritance), the individual spell starts later accordingly. The spell ends at the time of individual adoption. However, our sample also includes 427 farmers who had not adopted oil palm at the time of the survey in 2012. These non-adopters have not completed the adoption spell, so that they are right censored (Cleves et al., 2002). Hence, the maximum number of rows per household is 18, for the 18 years from 1995 to 2012. The dependent variable takes on the value zero in every year of non-adoption, and the value one when adoption occurred. The explanatory variables also change over time, except for time-invariant factors.

\subsubsection{MODEL SPECIFICATION}

In specifying the duration model we need to determine explanatory variables to be included, as well as functional form and related aspects to obtain reliable estimates. In terms of explanatory variables, we consider farmer, household, and village level variables, which may all play a role for the decision to adopt oil palm. Farmer characteristics that we include are age, education and migration background of the household head. Household characteristics include ownership of a car or pickup truck, which facilitates transportation of fruits to the processing mill, and a dummy capturing whether the household also pursues an own off-farm business. Such a business may affect the allocation of household capital and labor resources to agriculture. Except for education and migration background, these are time-variant variables. 
Concerning village level variables, we include a dummy indicating whether or not a contract with a palm oil company exists in the village. As mentioned, in our sample we only focus on independent farmers. But if other groups of farmers in the same village produce under contract, we know that a nearby processing mill must exist. There may also be knowledge spillovers between contracted and independent farmers. Further, we include the distance between the village and the closest market where food and nonfood consumption goods can be purchased. This is used as a proxy for remoteness. Note that the palm oil mills are usually not located in the same place as the market for consumer goods.

In addition to these farmer, household, and village level variables, we include dummies for four regencies, using Muaro Jambi as the reference regency. Finally, we include a time trend (taking on the values 1, 2, ..., 18 for calendar years 1995, 1996, ..., 2012) and the time-variant export price for palm oil (price for crude palm oil in 1,000 Indonesian Rupiah per kg, averaged over 3 years and inflation adjusted). Export price levels directly affect farmers' profit expectations and may thus influence their decision to adopt. For the estimates of the baseline hazards, all continuous variables (age, education, distance to market, and export price) are centered over their respective means. $^{8}$

We expect that village level factors beyond the question of whether or not a contract exists may affect adoption decisions. The contract dummy is an imperfect proxy for access to processing mills. Moreover, the share of farmers in a village cultivating oil palm, the total village oil palm area, or the degree of collective action may influence individual decisions. While we have information on such aspects for certain points in time, we do not have details for all years of the adoption spells. This may potentially lead to omitted variable bias (Abdulai and Huffman, 2005). Static village dummies can also not help in this dynamic modeling framework. A solution is the estimation of a duration model with shared frailties (Cleves et al., 2002), where the group sharing the same frailty is set at the village level. Shared frailty models can be used to model within group

\footnotetext{
${ }^{8}$ Mean values were taken over all observations and all years of the adoption spells.
} 
correlation, where observations belonging to the same group share the same frailty (Cleves et al., 2002). ${ }^{9}$

We estimate an extended Cox-model (Cox, 1972), leaving the form of the underlying baseline hazard unspecified. We do so because non-parametrical hazard estimates of our data do not reflect any commonly used parametric distributions. The data contain a large share of farmers who adopted oil palm at farm start, implying a relatively high hazard rate during the first year. In later years, adoption events are distributed more or less evenly. Furthermore, this approach allows us to analyze whether the effect of particular variables changes over time. Proportional hazard models assume no time dependency of covariate effects on the hazard ratios (Cleves et al., 2002). We find evidence for non-proportionality when running the non-extended Cox-model, which seems plausible given the long time horizon considered (18 years). One way to correct for non-proportionality is the inclusion of time interaction terms (Cleves et al., 2002; Singer and Willet, 1993). In our model, variables violating the proportional hazard assumption are interacted with the adoption spell length measured in years.

Formally, the hazard rate in our model is specified as:

$$
\lambda_{i j}\left(t \mid x_{i}, \gamma_{j}\right)=\lambda_{0}(t) * \exp \left(x_{i} \beta_{m}+\left(x_{i} * t_{i}\right) \beta_{t}+\log \gamma_{j}\right)
$$

where $\lambda_{i j}$ is the hazard rate of farmer $i$ in village $j, t$ is the duration of the adoption spell, $x_{i}$ the vector of explanatory variables, $\gamma_{j}$ the shared frailties in village $j$, and $\beta_{m}$ and $\beta_{t}$ the main and interaction effect coefficients to be estimated.

\footnotetext{
${ }^{9}$ Frailties are unobservable positive quantities, assumed to have mean one and variance theta, to be estimated from the data. Frailties are gamma distributed. If $\alpha_{j}$ is the group level frailty of the $\mathrm{j}^{\text {th }}$ group and $\gamma_{j}=\log \alpha_{j}$ then the hazard can be expressed as: $\lambda_{i j}(t)=\lambda_{0}(t) * \exp \left(x_{i} \beta+\right.$ $\gamma_{j}$ ). Log frailties are analogous to random effects in linear regression (Cleves et al., 2002).
} 


\subsection{RESULTS}

\subsubsection{PatTERns of OIL PALM ADOPTION}

Figure 2.1 shows the development of the area under oil palm in Indonesia, differentiating between large-scale estates and smallholder landholdings. Since 2000, smallholder farmers have more than tripled their oil palm area, reflecting their growing importance in this production sector.

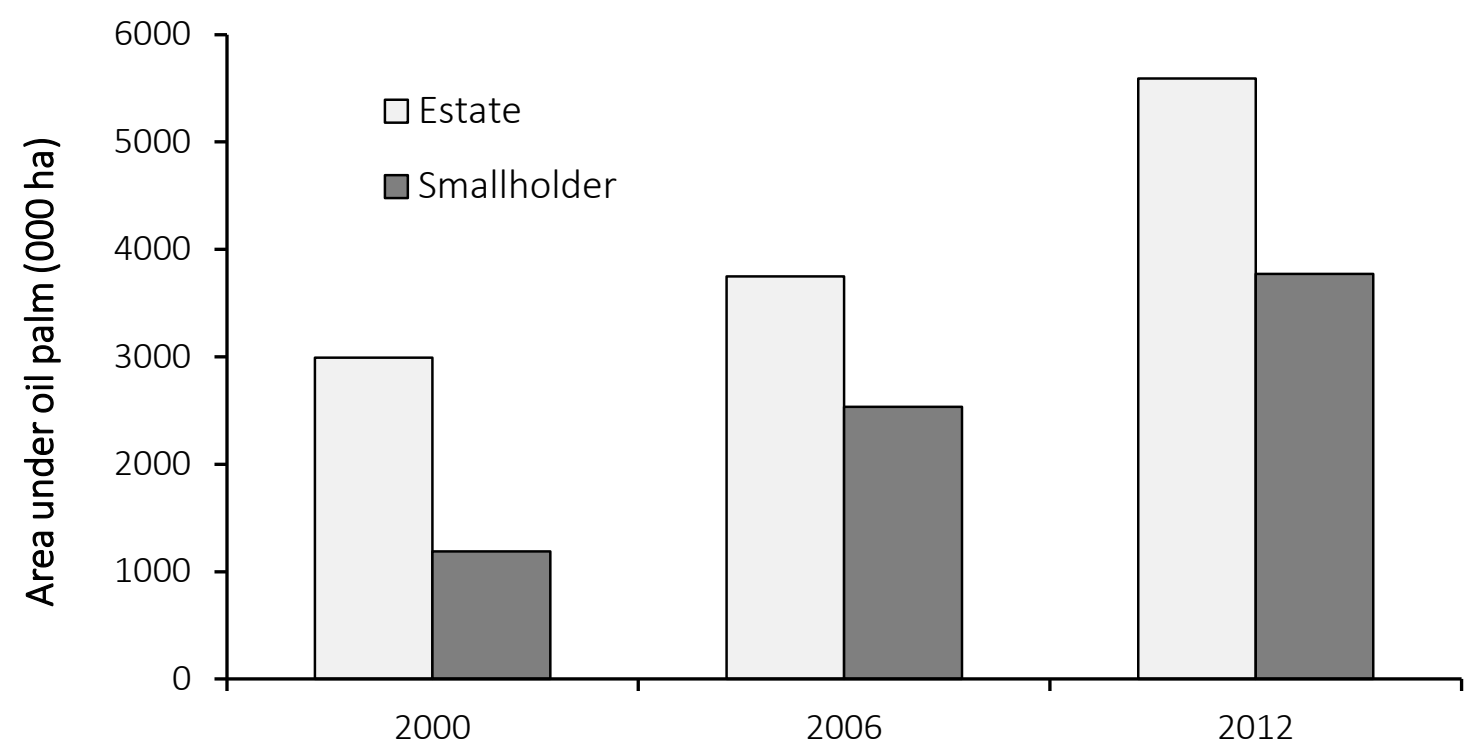

Figure 2.1. Area under oil palm in Indonesia by type of producer. Source: BPS, 2014.

Figure 2.2 uses data from our household survey to show how oil palm adoption developed among smallholder farmers in Jambi since the late-1980s. Adopting farmers are subdivided into those who adopted through participation in special government support programs and those who started independently. Additionally, independent adopters are disaggregated by migration background. Here, we do not refer to the government-supported transmigration program, but to spontaneous migration by individual households. Immigration to Jambi occurs from other parts of Sumatra, partly due to the booming oil palm industry. Furthermore, there is migration of households within Jambi, for instance the grownup children of farmers and their families looking for available land to start their own farm business. We define a household as migrant if the household head was not born in the current village of residence. 
Our survey data are in line with the national statistics, confirming an increasing participation of smallholders in oil palm cultivation. Figure 2.2 clearly shows that government-supported programs were basically the only option for smallholders to start oil palm cultivation until the mid-1990s. Since then, the number of supported farmers did not grow much further, reflecting the decreasing role of the government support programs and company out-grower and contract schemes. At the same time, independent smallholder adoption has increased significantly since the mid-1990s. Among the independent smallholders, migrants started to adopt earlier and faster than non-migrants, although growth rates between both groups have been similar since the early-2000s.

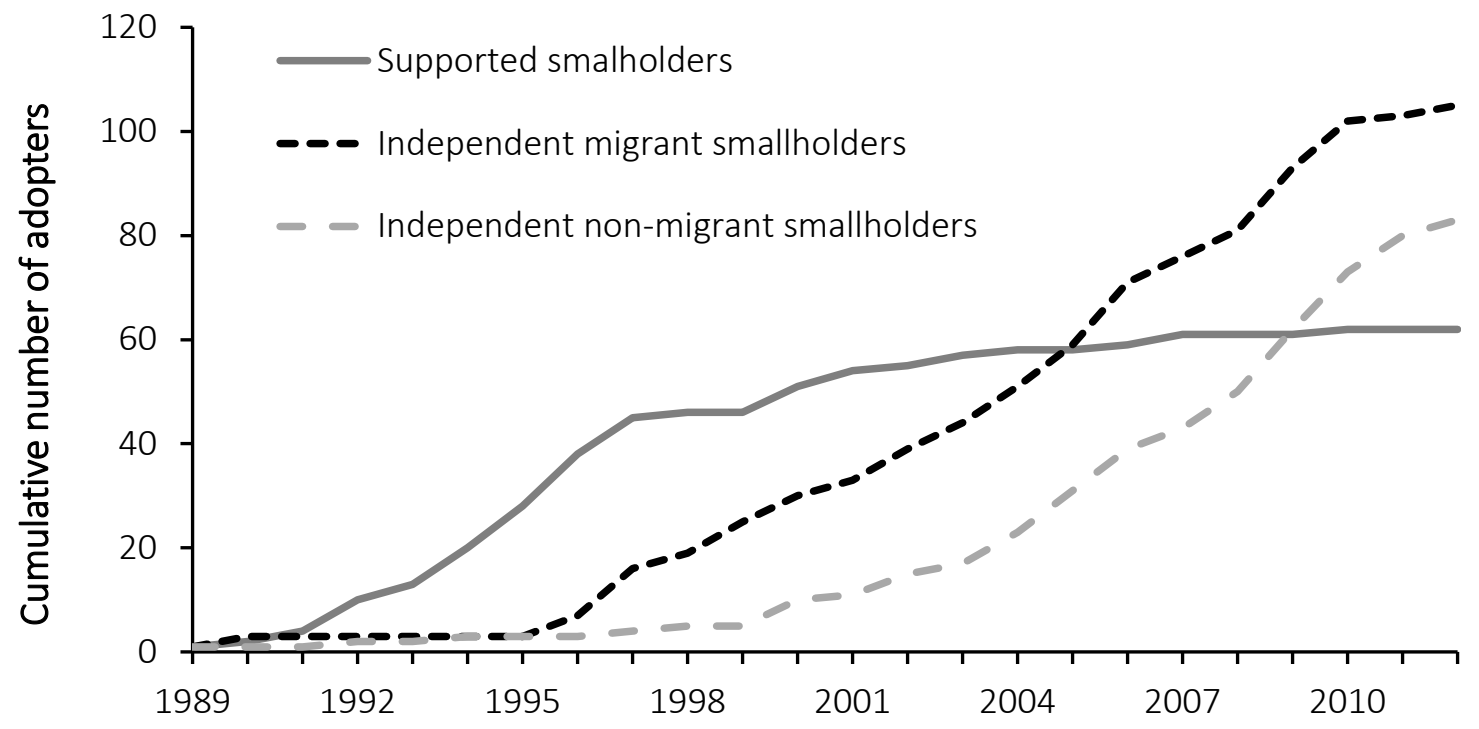

Figure 2.2 Cumulative frequency of oil palm adoption by type of adoption and migration background. Source: Household survey, 2012.

When looking at regional patterns of oil palm adoption, we find significant differences between Jambi's regencies. Figure 2.3 presents the share of independent oil palm farmers in a regency since 1995 relative to the regency's total sample of households. So far, most of the growth took place in Muaro Jambi and Sarolangun, followed by Batanghari. Growth rates in Tebo and Bungo were much lower. This is in line with official statistics from Jambi Province, showing that - out of the regencies included in our study - Muaro Jambi has the largest area under oil palm and the largest number of 
palm oil mills (BPS, 2012). The oil palm industry is more developed in Muaro Jambi, thus facilitating smallholder access to processing and output markets.

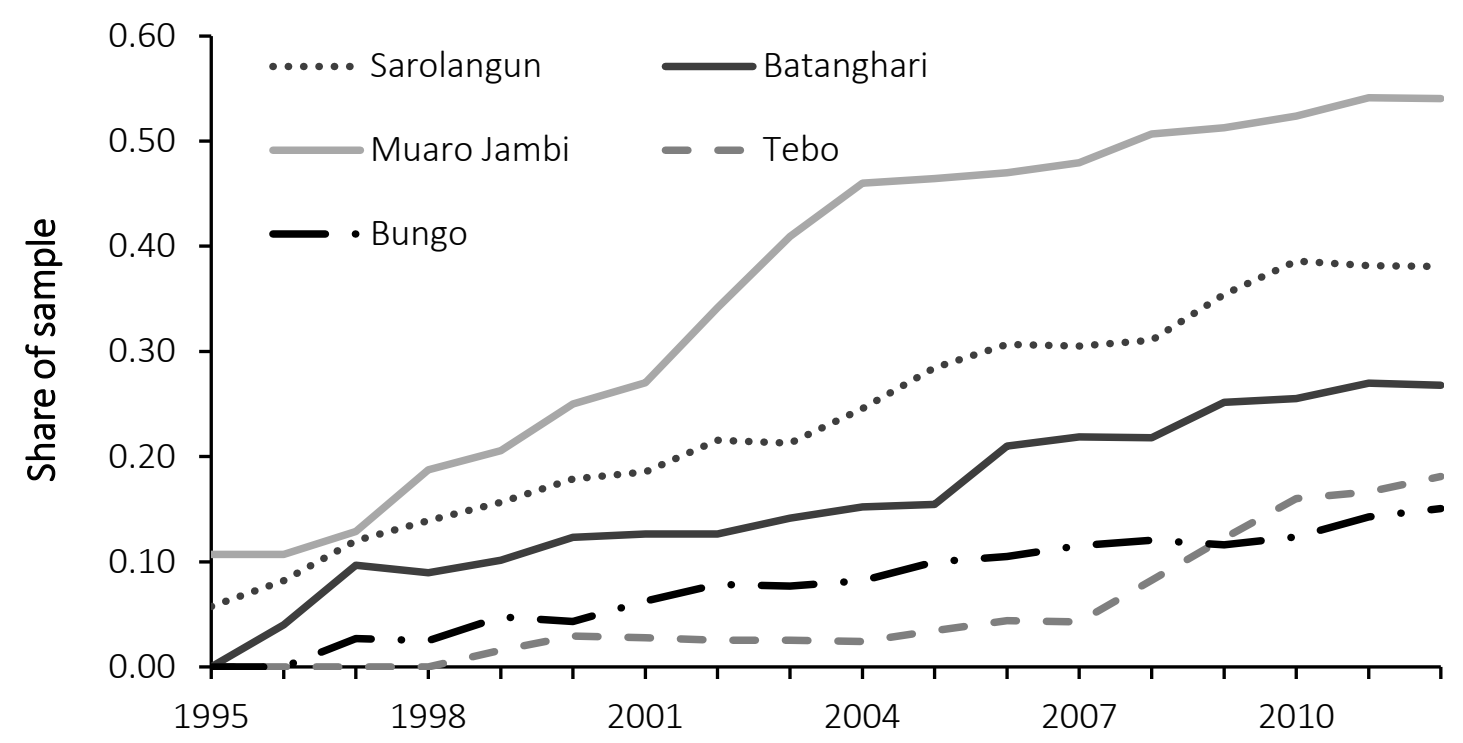

Figure 2.3. Share of independent oil palm adopters by regency. Source: Household survey, 2012.

\subsubsection{DESCRIPTIVE STATISTICS}

Table 2.1 shows descriptive statistics of farm households in our sample. The first two columns compare farm, household, and village level characteristics between oil palm adopters and non-adopters. As mentioned, for the statistical analysis we drop the subsample of supported adopters, so that adopters here only include independent oil palm growers. All values in Table 2.1 refer to 2012.

On average, oil palm adopters have started farming somewhat later than nonadopters. This seems reasonable, as many oil palm farmers started farming with oil palm as their first crop, which only became available for independent adoption in the mid1990s. Further, we find oil palm adopters to have significantly larger farm sizes. ${ }^{10}$ Twothirds of the oil palm farmers also cultivate rubber on their farm. As there is no significant difference in the rubber area, it seems that oil palm plantations are added to

\footnotetext{
${ }^{10}$ The relatively large farm size of oil palm adopters is due to a number of outliers; a few adopters own and cultivate more than 40 ha. The median farm size is 3.5 ha for adopters and 2 ha for non-adopters.
} 
the farm rather than substituted for rubber plantations. This is also consistent with a recent study using village level data (Gatto et al., 2014). Potential pathways of smallholder land acquisition for oil palm cultivation include purchase from the land market, inheritance, or forest encroachment, including degraded forestland (Krishna et al., 2014).

In terms of farmer and household characteristics, we find that adopters are somewhat younger and better educated than non-adopters. Adopters are also more likely to have a migration background when we consider all types of migration, including transmigration. ${ }^{11}$ However, no significant difference is found when we only consider spontaneous migration. Furthermore, there are no significant ethnic differences between adopters and non-adopters. While the government-supported NES schemes were dominated by migrants from Java, independent oil palm adoption seems to be widespread also among the autochthonous population in Sumatra, including the Melayu Jambi and other ethnicities. In terms of transport options and other economic activities, adopters are more likely to own a car or pickup and to run an off-farm business, mostly in trade and other services.

In terms of village characteristics, independent oil palm adopters are less likely to reside in autochthonous villages and more likely to reside in trans-migrant villages with NES schemes and other villages where oil palm contracts exist. This supports the notion of a regional path-dependency: in villages where ties to oil palm companies and access to processing facilities already exist, smallholders find it much easier to also adopt oil palm independently. This path-dependency is also confirmed when looking at historical land use at the village level. As can be seen in Table 2.1, independent adoption occurred more widely in villages that had more oil palm already in 1992. Furthermore, oil palm adoption occurred more widely in villages that still had more forestland in 1992. In terms of distance to market, we do not find significant differences between oil palm adopters and non-adopters.

\footnotetext{
${ }^{11}$ While we dropped farmers who grew oil palm only as part of a government-sponsored scheme, many trans-migrants later also started independent oil palm cultivation. In that case, they are included in the sample.
} 
Table 2.1. Descriptive statistics by adoption and migration status.

\begin{tabular}{|c|c|c|c|c|}
\hline \multirow[b]{2}{*}{ Variable } & \multicolumn{2}{|c|}{ By adoption status } & \multicolumn{2}{|c|}{ By migration status } \\
\hline & $\begin{array}{l}\text { Adopters } \\
(n=188)\end{array}$ & $\begin{array}{c}\text { Non- } \\
\text { adopters } \\
(\mathrm{n}=427)\end{array}$ & $\begin{array}{c}\text { Migrants } \\
(n=314)\end{array}$ & $\begin{array}{c}\text { Non- } \\
\text { migrants } \\
(n=301)\end{array}$ \\
\hline \multicolumn{5}{|l|}{ Farm characteristics } \\
\hline Year of farm start & $\begin{array}{c}1999^{* * *} \\
(9.21)\end{array}$ & $\begin{array}{l}1997 \\
(9.78)\end{array}$ & $\begin{array}{l}1998 \\
(9.20)\end{array}$ & $\begin{array}{c}1997 \\
(10.11)\end{array}$ \\
\hline Total farm size (ha) & $\begin{array}{l}7.14^{* * *} \\
(11.59)\end{array}$ & $\begin{array}{c}3.45 \\
(4.73)\end{array}$ & $\begin{array}{c}4.50 \\
(8.01)\end{array}$ & $\begin{array}{c}4.66 \\
(7.38)\end{array}$ \\
\hline $\begin{array}{l}\text { Share of households cultivating } \\
\text { oil palm (\%) }\end{array}$ & 100 & 0 & $33^{*}$ & 28 \\
\hline Area under oil palm (ha) & $\begin{array}{c}3.59 \\
(6.46)\end{array}$ & 0 & $\begin{array}{c}1.23 \\
(4.34)\end{array}$ & $\begin{array}{c}0.96 \\
(3.45)\end{array}$ \\
\hline $\begin{array}{l}\text { Share of households cultivating } \\
\text { rubber (\%) }\end{array}$ & $67^{* * *}$ & 100 & $88^{* *}$ & 92 \\
\hline Area under rubber (ha) & $\begin{array}{c}3.46 \\
(6.80)\end{array}$ & $\begin{array}{c}3.35 \\
(4.71)\end{array}$ & $\begin{array}{l}3.20^{*} \\
(5.05)\end{array}$ & $\begin{array}{c}3.58 \\
(5.80)\end{array}$ \\
\hline \multicolumn{5}{|l|}{ Farmer and household characteristics } \\
\hline $\begin{array}{l}\text { Age of household head } \\
\text { (years) }\end{array}$ & $\begin{array}{l}43.05^{* *} \\
(11.85)\end{array}$ & $\begin{array}{c}44.45 \\
(12.07)\end{array}$ & $\begin{array}{c}45.56^{* * *} \\
(11.72)\end{array}$ & $\begin{array}{c}42.42 \\
(12.13)\end{array}$ \\
\hline $\begin{array}{l}\text { Education of household head } \\
\text { (years of schooling) }\end{array}$ & $\begin{array}{l}8.37^{* * *} \\
(3.77)\end{array}$ & $\begin{array}{l}7.43 \\
(3.57)\end{array}$ & $\begin{array}{l}7.51^{* *} \\
(3.68)\end{array}$ & $\begin{array}{c}7.94 \\
(3.62)\end{array}$ \\
\hline $\begin{array}{l}\text { Share of household heads that migrated to } \\
\text { village of current residence (\%) }\end{array}$ & $56^{* *}$ & 49 & 100 & 0 \\
\hline $\begin{array}{l}\text { Share of household heads that participated in } \\
\text { transmigration program (\%) }\end{array}$ & 11 & 8 & 18 & 0 \\
\hline $\begin{array}{l}\text { Share of household heads originating from } \\
\text { Java (\%) }\end{array}$ & 46 & 44 & $73^{* * *}$ & 15 \\
\hline $\begin{array}{l}\text { Share of household heads that migrated } \\
\text { spontaneously to village of residence (\%) }\end{array}$ & 45 & 41 & 82 & 0 \\
\hline Share of households owning a car/pickup (\%) & $26^{* * *}$ & 9 & 15 & 14 \\
\hline $\begin{array}{l}\text { Share of households running an off-farm } \\
\text { business (\%) }\end{array}$ & $30^{* * *}$ & 18 & 22 & 21 \\
\hline \multicolumn{5}{|l|}{ Village level characteristics } \\
\hline $\begin{array}{l}\text { Share of households residing in } \\
\text { autochthonous villages (\%) }\end{array}$ & $57^{* * *}$ & 71 & $48^{* * *}$ & 86 \\
\hline $\begin{array}{l}\text { Share of households residing in oil palm } \\
\text { trans-migrant villages (\%) }\end{array}$ & $20^{* * *}$ & 6 & $18^{* * *}$ & 2 \\
\hline $\begin{array}{l}\text { Share of households residing in village that } \\
\text { has a contract with palm oil company (\%) }\end{array}$ & $45^{* * *}$ & 16 & $30^{* * *}$ & 21 \\
\hline Distance to closest market $(\mathrm{km})$ & $\begin{array}{c}5.38 \\
(6.00)\end{array}$ & $\begin{array}{c}5.86 \\
(5.31)\end{array}$ & $\begin{array}{c}6.23^{* * *} \\
(5.06)\end{array}$ & $\begin{array}{c}5.17 \\
(5.93)\end{array}$ \\
\hline $\begin{array}{l}\text { Village share of agricultural land under oil } \\
\text { palm in } 1992^{\mathrm{a}}(\%)\end{array}$ & $14^{* * *}$ & 7 & $15^{* * *}$ & 3 \\
\hline Village share of forest land in $1992^{\mathrm{a}}(\%)$ & $36^{* * *}$ & 22 & 25 & 28 \\
\hline
\end{tabular}


As migration seems to play an interesting role, the third and fourth columns of Table 2.1 compare descriptive statistics between migrant and non-migrant households. We find that the heads of migrant households are older and somewhat less educated than the heads of non-migrant households on average. They are also much more likely to be of Javanese origin. Many of the farmers with Javanese origin came to Jambi through the government's trans-migration programs. In addition, trans-migrants and other migrants from Java (and their children) are also more likely to migrate within Jambi than the autochthonous population. Migrants tend to cultivate less rubber and somewhat more oil palm, although the difference in the oil palm area is not statistically significant. Comparing village level characteristics, migrants are more likely to reside in villages where oil palm cultivation started early on and where contracts with a palm oil company exist. Since spontaneous migrants in Jambi choose their villages of destination themselves, it is likely that they choose villages with favorable conditions, including good access to the palm oil processing industry.

\subsubsection{DURATION MODEL RESULTS}

Figure 2.4 shows the so-called Kaplan-Meier estimates of the survival function, describing the relationship between the length of the adoption spell and the share of non-adopting farmers. ${ }^{12}$ Even though the adoption of oil palm is further increasing among smallholder farmers, overall adoption rates remain moderate. At the time of the survey in 2012, around two-thirds of the farmers had not adopted oil palm. More traditional land uses, especially rubber, still dominate smallholder farming in the study area. The large decline in the first year of the spell in Figure 2.4 indicates that a large share of farmers have actually adopted oil palm when they personally started their farming business.

\footnotetext{
${ }^{12}$ The term 'survival function' comes from the medical use of duration analysis. The KaplanMeier estimate makes no assumption about the underlying distribution of times to adoption. The survival estimate for a given period is derived by dividing the number of households that have not adopted oil palm in the respective period by the total number of households exposed to adoption during the same period (Burton et al., 2003).
} 


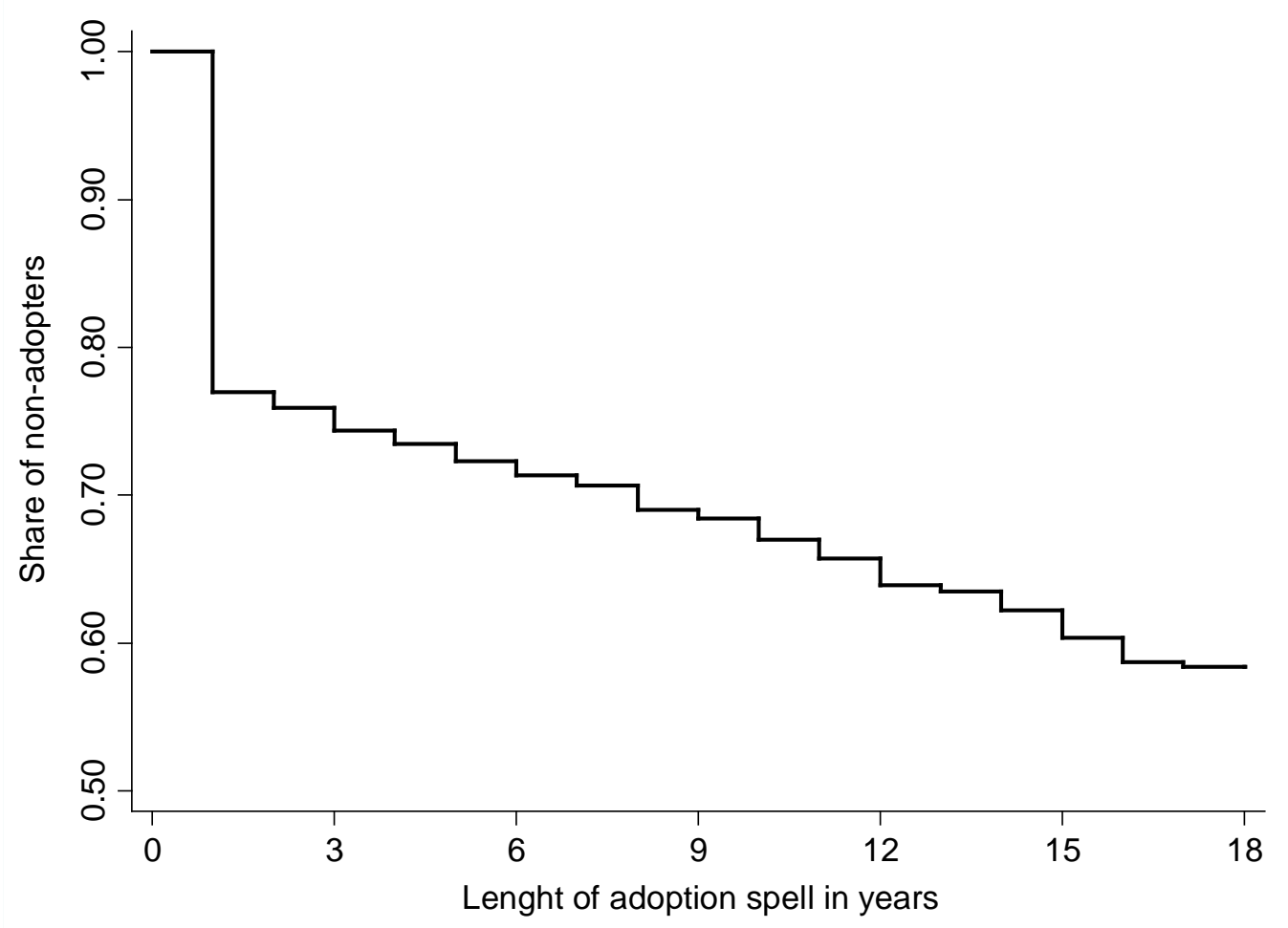

Figure 2.4. Kaplan-Meier survival estimates. Source: Household survey, 2012.

Table 2.2 presents the results of the duration model. The first column shows the estimated coefficients for the explanatory variables. The second column shows the hazard ratios defined as the exponential of the coefficient. A hazard ratio larger than one (a positive coefficient) implies that the variable speeds up the adoption process, while a hazard ratio smaller than one (a negative coefficient) means that the variable slows down adoption. Marginal effects are obtained by subtracting one from the hazard ratio.

We start the interpretation with the time trend. The hazard ratio of 2.00 indicates that the probability of oil palm adoption increases by $100 \%$ every year, starting from 1995. However, the estimates for the square term show that this effect is not linear. The maximum increase in the adoption probability is reached after 13 spells (corresponding to the year 2007); after that the effect gets smaller again. In other words, even though oil palm adoption is still increasing in Jambi, it seems that the peak speed of the diffusion process has already been passed. This is consistent with a recent analysis of village level data from Jambi (Gatto et al., 2014), but is not necessarily true 
for Indonesia as a whole. Rapid expansion of oil palm is observed on the islands of Kalimantan and Papua (Sheil et al., 2009). Reasons for the decelerated expansion of oil palm in Jambi are not entirely clear. It is possible that the existing processing mills have reached their absorption capacity. In any case, free land resources are becoming scarcer in Jambi, and a conversion from rubber to oil palm does not seem to be lucrative for everyone.

The palm oil export price is positively associated with the speed of adoption. This is not surprising, because higher output prices provide added incentives for farmers to enter this market. Relative to the mean inflation-adjusted price of 9,211 Indonesian Rupiah per kg of crude palm oil, a 1000 Rupiah increase raises the hazard rate by $21 \%$. Wheeler et al. (2013) showed that palm oil prices play an important role for the expansion of large-scale plantations. Our results suggest that the same effect is also observed among smallholders.

Living in a village where a contract with a palm oil company exists increases the speed of adoption significantly; marginal effects on the hazard rate of adoption are $113 \%$ compared to non-contract villages. As discussed above, we consider a village contract as an indicator for better access to processing mills and technical knowledge.

The descriptive statistics suggested that migration background may also affect oil palm adoption. Yet, migration as such is not significant in the duration model. Nor is the interaction term between migration and village contract statistically significant, suggesting that migrants in villages with contracts do not adopt faster than nonmigrants in the same villages. We infer that migration background does not have a direct effect on independent oil palm adoption. ${ }^{13}$ An indirect effect occurs because spontaneous migrants choose their destination and seem to have a preference for villages where a contract with a palm oil company exists. Migrants that intend to start oil palm cultivation choose locations with good access to processing mills. Furthermore,

\footnotetext{
${ }^{13}$ When supported oil palm adoption through NES and KKPA out-grower schemes is also considered, there is a positive association between migration background and oil palm adoption because of the transmigration program. As explained above, our duration analysis focuses on independent oil palm adoption only.
} 
villages with a contract are often more wealthy than villages without a contract (McCarthy, 2010) and thus more attractive destinations for migrants.

Table 2.2. Estimation results of duration model.

Coefficient Hazard ratio

Time and price trends
Time trend
Time trend squared
Palm oil export price
Village contract and migration
Village level contract with palm oil company (dummy
Household head migrated to village (dummy)
Household migrated* village level contract
Farmer and household characteristics
Age of household head (years)
Age of household head squared
Education of household head (years of schooling)
Household owns a car/pickup (dummy)
Household owns a car/pickup* adoption spell leng
Household runs an off-farm business (dummy)
Household runs a business* adoption spell length
Village level and regional characteristics
Distance to closest market (km)
Distance to closest market* adoption spell length
Sarolangun regency (dummy)
Sarolangun regency* adoption spell length
Batanghari regency (dummy)
Tebo regency (dummy)
Bungo regency (dummy)
Randomly-selected village (dummy)
Randomly-selected household (dummy)
Theta

Time and price trends

Time trend

Village contract and migration

$0.69^{* * *}(0.16)$

$2.00^{* * *}$

$-0.03^{* * *}(0.01)$

$0.97^{* * *}$

$0.19^{* * *}(0.06)$

$1.21^{* * *}$

$\begin{array}{cc}0.76^{* *}(0.35) & 2.13^{* *} \\ 0.05(0.21) & 1.05 \\ 0.45(0.36) & 1.56\end{array}$

$0.06^{* * *}(0.01)$

$1.06^{* * *}$

$-6 \mathrm{E}-04^{* * *}(4 \mathrm{E}-04)$

$0.99^{* * *}$

$0.11^{* * *}(0.02)$

$1.12^{* * *}$

$0.16^{* *}(0.42)$

$1.18^{* *}$

$0.07^{* *}(0.05)$

$1.07^{* *}$

$-0.21^{* *}(0.33)$

$0.81^{* *}$

$0.09^{* *}(0.04)$

$1.10^{* *}$

$\begin{array}{cc}0.01(0.03) & 1.01 \\ -0.01(3 \mathrm{E}-03) & 0.99 \\ -0.93^{* * *}(0.45) & 0.40^{* * *} \\ -0.06^{* * *}(0.03) & 0.94^{* * *} \\ -1.35^{* * *}(0.43) & 0.26^{* * *} \\ -1.82^{* * *}(0.50) & 0.16^{* * *} \\ -1.98^{* * *}(0.50) & 0.14^{* * *} \\ -0.51(0.40) & 0.60 \\ -0.54(0.34) & 0.58\end{array}$

Number of subjects

615

$0.32^{* * *}(0.13)$

Number of failures (completed adoption spells)

Wald chi $^{2}$

185.87

Log pseudo-likelihood

$-991.43$

Notes: Standard errors are shown in parentheses. Hazard ratios are defined as exp(coefficient). ", indicate $5 \%$ and $1 \%$ level of significance, testing that the coefficients are equal to zero and the hazard ratios equal to unity.

In terms of farmer and household characteristics, age and education of the household head both increase the speed of oil palm adoption. One additional year of 
education (beyond the sample average of 7 years of schooling) increases the hazard rate by $12 \%$. Oil palm productivity is sensitive to plantation management, such as the quantity and timing of fertilizer application and the length of harvest intervals. More educated farmers may have better access to information and will find it easier to adjust to the management requirements, which differ from those of rubber. Farmer age is a proxy for farming experience. More experience also helps to successfully adjust to a new plantation crop. Even though the square term age coefficient is negative, this effect is very small.

Ownership of a car/pickup increases the hazard rate by $18 \%$. Households with an own means of transportation have a clear advantage, as they are not dependent on middlemen to transport inputs and outputs. Transportation flexibility is more important for oil palm than for rubber, because oil palm is more input-intensive and the harvested fruits are perishable. The interaction term between car ownership and adoption spell length indicates that the effect is even increasing over time. In contrast, running an offfarm business lowers the hazard rate of oil palm adoption by $19 \%$. This could be due to competing capital requirements, as the establishment of a new oil palm plantation is capital-intensive. The positive interaction term with spell length indicates that access to capital may have improved over time for smallholders in Jambi. Interestingly, the descriptive results above showed that adopters are more likely to run an off-farm business, but this comparison did not account for the time dimension. The duration analysis suggests that oil palm cultivation facilitates the start of other businesses and not vice versa.

In terms of the regional characteristics, distance to the closest market does not affect the speed of oil palm adoption. But the regency effects are significant. All regency dummies have negative coefficients, meaning that oil palm adoption in these regencies was and is much slower than in the reference regency Muaro Jambi. Residing in Sarolangun and Batanghari decreases the hazard rate of adoption by $60 \%$ and $74 \%$, respectively. In Tebo and Bungo the hazard rate is $84 \%$ and $86 \%$ lower than in Muaro Jambi. In Sarolangun the relative hazard rate decreases further with increasing spell 
length (the other interaction terms were not significant). Muaro Jambi is clearly the regency with the fastest adoption of oil palm. As mentioned above, Muaro Jambi is the regency with the most developed palm oil industry and the largest number of processing mills. Muaro Jambi is also closest to Jambi City, where the province's only port for imports of farm inputs and exports of palm oil is located. The favorable infrastructure conditions in Muaro Jambi facilitate oil palm adoption by independent smallholders.

The coefficient for theta of 0.32 is significant and indicates that there are frailty effects. As discussed above, frailty effects may be due to additional village level variables for which we do not have data for all years of the adoption spells. Our specification of the duration model with shared frailties controls for omitted variable bias that could otherwise be a problem. ${ }^{14}$

\subsection{CONCLUSION}

Oil palm was identified as a driver of deforestation in Indonesia. There are also broader environmental and social concerns associated with the rapid expansion of oil palm. Even though much of the oil palm cultivation takes place on large-scale plantations, the share of smallholder farmers is significant and further growing. While the establishment of large-scale plantations can be planned and regulated, the oil palm expansion in the small farm sector is more difficult to control. There is not even a good understanding of the factors that influence land use changes among smallholders. In this chapter, we have addressed this knowledge gap by using data from a survey of smallholder farm households in Jambi, Sumatra. We have developed and estimated a duration model to analyze the determinants of oil palm adoption at the micro level.

The first smallholders started growing oil palm in Jambi in the late-1980s. At that time, smallholders participated in government-supported out-grower schemes. These were often trans-migrants originating from Java. Since the mid-1990s, smallholders also started to adopt oil palm independent of government support. While smallholder

\footnotetext{
${ }^{14}$ Further analysis confirms that positive values for log-frailties (and hence positive effects of village level unobservables on the hazard rate of adoption) are indeed associated with villages that have larger oil palm areas.
} 
contracts and out-grower schemes still exist, most of the oil palm growth among smallholders is now due to independent adoption. Our analysis has focused on explaining the patterns of this independent adoption. While oil palm adoption is still increasing in Jambi, adoption rates have started to decelerate recently. Rubber is still the dominant smallholder crop in the region. Our data suggest that this is not going to change any time soon.

Migrant farmers from Java are more likely to grow oil palm than the autochthonous population in Jambi, which is primarily due to the former transmigration programs that focused on oil palm cultivation. However, in our analysis of independent farmers we found no significant difference in the speed of oil palm adoption between migrants and locals. Factors that increase the speed of adoption are farmer education and experience, which can be explained by the fact that successful oil palm cultivation requires new technical and managerial knowledge. Furthermore, ownership of a car or truck facilitates adoption, as inputs and outputs have to be transported in a timely manner. Our estimation results also show that the export price of palm oil influences smallholder decisions. Higher export prices accelerate oil palm adoption significantly.

Yet, one of the most important factors for the speed of adoption is the existence of a village contract with a palm oil company. Even though independent oil palm growers are not included in such contracts, the existence of a contract in the village ensures that a company with processing facilities is nearby. Good access to processing facilities is important, because oil palm fruits have to be milled within 48 hours after harvest. A contract in the village and other farmers who participate in an out-grower scheme for oil palm may also improve access to technical information for independent adopters.

Government policy has started oil palm cultivation in Sumatra in the 1980s. Through the establishment and support of large-scale plantations, processing facilities, and smallholder out-grower schemes, these policies have also contributed to a regional path-dependency. Regions where the oil palm industry was developed early on are also those regions where independent oil palm adoption now occurs most widely. This path- 
dependency has a potential downside, as it may foster regional disparities. However, there is also a positive side, because land use change becomes more predictable and easier to control for public policymakers. The government is still the entity that grants concessions for large-scale plantation establishment by private or public companies. Hence, there is an indirect influence also on the regional patterns of independent smallholder oil palm expansion. The environmental sustainability of future oil palm expansion therefore depends on the government's ability to demark land for plantation development that is already degraded, so to spare primary forest areas from direct encroachment. 


\title{
CHAPTER 3: LIVELIHOOD IMPACTS OF OIL PALM EXPANSION AMONG SMALLHOLDERS
}

\begin{abstract}
The recent expansion of oil palm in Indonesia is largely smallholder-driven. However, its socio-economic implications are under-examined. Analyzing farmhousehold data from Jambi Province, Sumatra, oil palm adoption is found to have positive consumption and nutrition effects. However, these effects are largely due to farm size expansion that is associated with oil palm adoption. Potential heterogeneity of effects among oil palm adopters is examined using quantile regressions. While nutrition effects of oil palm adoption are found to be homogenous across quantiles, the effects on non-food expenditure are expressed more strongly at the upper end of the expenditure distribution.
\end{abstract}

\subsection{INTRODUCTION}

Oil palm has become one of the most rapidly expanding crops throughout the humid tropics, because of the rising demand for vegetable oils and biofuels, favorable government policies in producer countries, as well as its superior production potential and profitability compared to alternative land uses (Carrasco et al., 2014; Sayer et al., 2012; OECD and FAO, 2011; McCarthy and Cramb, 2009). Over the last two decades, the area under oil palm has almost tripled and its production quadrupled (FAOSTAT, 2014). Over $85 \%$ of the world's palm oil production originates from Indonesia and Malaysia, which offer favorable agro-ecological growing conditions with relative abundance of cultivable land and agricultural labor (Basiron, 2007). The increasing product demand coupled with localized production of oil palm and related land use changes have significant environmental and socio-economic implications.

While the environmental consequences of associated land use changes have received considerable research focus (Carrasco et al., 2014; Margono et al., 2014; Koh and Lee, 2012; Wilcove and Koh, 2010; Buttler and Laurence, 2009; Danielsen et al., 
2009), empirical studies on its socio-economic implications remain scarce. The human dimension of oil palm expansion deserves special attention, especially since the recent land use changes are largely driven by smallholder farmers. Smallholders account for $41 \%$ of the total oil palm area and for $36 \%$ of the total fresh fruit bunch (FFB) production in Indonesia, the world's leading producer of palm oil (ISPOC, 2012). If the current trend continues, smallholders are expected to dominate the Indonesian palm oil sector in the near future (BPS, 2015). The outcome of oil palm adoption on farmers' livelihoods is a widely debated topic: While threats include an increasing vulnerability and economic marginalization of the rural population (McCarthy, 2010; Rist et al., 2010; Sheil et al., 2009), as well as unequally distributed benefits among oil palm adopters (Cramb and Curry, 2012; McCarthy, 2010), opportunities entail livelihood improvements through increased incomes, rural development and poverty reduction (Cahyadi and Waibel, 2013; Sayer et al., 2012; Feintrenie et al., 2010; Rist et al., 2010). Further, in a broad sense, farmer specialization in non-food cash crops like oil palm has been criticized for decreasing on farm production diversity, declining significance of subsistence food crops, greater farmer dependency on trade and markets to satisfy nutritional needs, and increased livelihood vulnerability to price shocks on international commodity markets (Pellegrini and Tasciotti, 2014; Jones et al., 2014; World Bank, 2007; von Braun, 1995). For a society, however, the negative implications might be compensated by increased household incomes resulting from the adoption of non-food cash crops.

Surprisingly, there is only limited empirical evidence on the livelihood and nutritional implications of oil palm adoption (Cramb and Curry, 2012; Feintrenie et al., 2010; Rist et al., 2010). To the best of our knowledge, only Krishna et al. (2015) and Cahyadi and Waibel (2013) have analyzed the welfare implication of oil palm adoption empirically, building on econometric models. Krishna et al. (2015) employ endogenous switching regressions to model the impacts of oil palm adoption using total annual consumption expenditures as a proxy for household welfare. Cahyadi and Waibel (2013) focus on the effects of contract versus independent oil palm cultivation, however not including non-adopters in their analysis. We are not aware of any study that has analyzed the implications of oil palm adoption on household consumption expenditures, 
calorie consumption and dietary quality. Disentangling welfare implications of oil palm expansion on smallholders is of paramount importance, not only to understand how government strategies and trade policies affect smallholders, but also to foresee how these factors incentivize smallholders to expand their farming activities that may give rise to social challenges and significant ecological problems. Moreover, in an environment of widespread malnutrition and undernourishment it is crucial to assess the implications of the recent expansion of oil palm plantations on household nutrition and the prevalence of food security. ${ }^{15}$

The present study contributes to the literature by quantifying the implications of oil palm cultivation on smallholder livelihoods, using household survey data from Jambi province, Sumatra. Effects of oil palm adoption on consumption expenditure, calorie consumption and dietary quality are analyzed using econometric models. Unlike more traditional land uses (e.g. rubber plantations), the cultivation of oil palm requires farmers to adapt to a new set of agronomic management practices and to get accustomed to new input and output marketing channels. It is likely that smallholder respond differently to these emerging challenges. Thus, the benefits of oil palm adoption are expected to differ among the group of adopters. In order to account for possible heterogeneity of effects, we rely on a set of quantile regressions.

This chapter is structured as follows. Section 3.2 lays out possible impact pathways of oil palm cultivation on household welfare and nutrition and introduces potential sources of impact heterogeneity. Section 3.3 describes the study area, data base and socio-economic characteristics of the sample and highlights differences in land use profitability between oil palm and rubber plantations. Section 3.4 introduces the analytical framework, the econometric approach and addresses the issue of endogeneity due to self-selection bias. Section 3.5 presents and discusses the results, while section 3.6 concludes.

${ }^{15}$ In 2013, 37.2\% of all Indonesian children were stunted and $11.4 \%$ of the Indonesian population lived below the poverty line (FAO et al., 2014). 


\subsection{POTENTIAL IMPACT PATHWAYS OF OIL PALM ADOPTION}

How does oil palm expansion affect household consumption expenditures and calorie consumption of smallholder farmers? It may be noted that the initial diffusion of oil palm in Jambi was mainly related to government supported smallholder schemes, in which farmers operated under contractual ties with large scale companies (Zen et al., 2006). More recently, smallholders took up oil palm independently and sporadically, without any government or private sector support (Euler et al., 2015; Gatto et al., 2014). Irrespective of whether the smallholder adoption was sporadic or supported, oil palm was a novel crop and a livelihood option in the context of smallholder agriculture. Smallholders either specialize in oil palm cultivation, or keep it supplementary to existing crops, especially rubber plantations (Euler et al., 2015; BPS, 2012). As management requirements between both crops differ widely, the adoption of oil palm will induce changes in the allocation of household resources (land, labor and capital) between and within farm and off-farm activities. In principle, there are two mayor pathways through which oil palm cultivation could affect household income, consumption expenditure and calorie consumption.

I. Through increases in farm income: Oil palm adoption might release household labor resources by demanding lower levels of labor input and thereby allow the expansion of farm area and the diversification of crop production. The reallocation of household resources might induce a change in on-farm production patterns and in the composition of farm income. Oil palm adoption may also directly affect household nutrition through a shift from food to non-food crop production.

II. Through increases in off-farm income: Household labor and capital resources might also be re-allocated between farm and off-farm activities. In particular, the amount of family labor invested in off-farm activities might increase and alter the composition of total household income and the relative importance of farm and offfarm income sources. 
Are welfare effects of oil palm consistent across the poor and the rich? While average household incomes are expected to rise with oil palm adoption, the magnitude of observed increases would depend on the capacity of a given household to expand its farm size and diversify its income sources. These depend on a set of household and farm attributes that are not homogeneous across adopters. In particular, those adopters with better access to capital and land may find it easier to expand their farms, and those residing in proximity to commercial centers might have better off-farm income opportunities. Hence, it is unlikely that adopters are able to realize income and consumption expenditure surpluses in a similar magnitude. Some adopters, especially those with surplus family labor, might not even realize any income effect of oil palm.

We further expect to observe heterogeneous effects of oil palm adoption on consumption expenditure and calorie consumption, as adopters may have different income elasticities of demand. In particular, the effects of oil palm adoption are likely to depend on the household's general consumption levels. Oil palm adoption might positively affect food expenditures and calorie consumption especially for those adopters at the lower tail of the distribution of total consumption expenditures. In turn, there might be no significant effect at the upper tail, as household are at saturation levels with respect to food intake. Moreover, adoption might positively affect dietary quality at the mid to upper tails of the total expenditure distribution as households have the economic means to not only meet their calorie needs but to also diversify their diets by consuming more nutritious but also more expensive food items. We further expect the effects of adoption on non-food expenditure to become larger while moving from the lower to the upper quantiles of the distribution of total consumption expenditure. In addition, the demand for non-food items is expected to be more elastic compared to food items. Knowing the effects of oil palm adoption at different points of the expenditure and calorie consumption distributions gives a more complete picture of its economic effects. 


\subsection{DATA BASE, SAMPLE CHARACTERISTICS AND LAND USE PROFITABILITY}

\subsubsection{STUDY AREA AND DATA BASE}

A comprehensive farm-household survey, conducted in Jambi province, Sumatra, provides the primary database for the present study. Jambi is one of the hotspots of recent oil palm expansion. Among all provinces in Indonesia, it ranks seventh in terms of cultivated oil palm area (over 0.72 million hectares) and sixth in terms of crude palm oil (CPO) production (around 1.70 million tons per year) (BPS, 2015). As previously indicated, this development largely involves smallholder farmers.

The prevalence of plantation agriculture might have significant impacts on farmer welfare in the study area. Only around $8 \%$ of Jambi's total population lives below the poverty line of 270 thousand Indonesian Rupiah (IDR) per capita per month (around 28 US Dollar, exchange rate September 2012), which is considerably below the Indonesian average of $12 \%$ (BPS, 2014). Across Indonesia, Jambi is among the provinces with the highest average calorie consumption per capita (MPW et al., 2006) and the lowest vulnerability to food insecurity (DKP et al., 2009). Delineation of the causes of relative economic welfare of Jambi farmers has not been carried out.

In order to represent the major shares of oil palm farmers and cultivated oil palm area, we purposively selected five lowland regencies (Sarolangun, Batanghari, Muaro Jambi, Tebo, Bungo). To ensure spatial diversity within these regencies, we followed a multi-stage random sampling approach, stratifying on the regency, district and village level. Accordingly, four districts per regency, and two villages per district were selected randomly. As selected villages were found to differ significantly with respect to population size, households were selected proportionally according to village size, averaging 15 households per village. Details of the sampling methodology are included in Faust et al. (2013). An additional five villages in which supporting research activities were carried out were purposively selected. From these villages, 83 households were selected randomly, yielding a total of 683 household-level observations. For our 
statistical analysis, we excluded 19 observations. ${ }^{16}$ Hence our final analysis is composed of 664 farmers, including 199 oil palm adopters and 465 non-adopters. ${ }^{17}$ We control for non-randomly selected villages in the statistical analysis. Data was collected between September and December 2012 through face to face interviews using structured questionnaires. Information on socio-economic household characteristics, farm endowments, agricultural activities, and off-farm income sources, as well as a detailed consumption expenditure module were gathered.

\subsubsection{SAMPLE CHARACTERISTICS}

There is a significant difference in many socio-economic variables between adopters and non-adopters, as shown in Table 3.1. With respect to farm characteristics, adopters tend to have larger land endowments. This can mainly be attributed to the fact that a considerable share of adopters is also engaged in the cultivation of rubber, yet on a significantly smaller area than non-adopters. Rist et al. (2010) also report a preference of smallholders to cultivate both crops. Accordingly, farmers use oil palm to supplement rubber harvests during the rainy season, in which rubber yields are considerably lower. Cultivating both crops would also help to reduce price fluctuations in international markets. Lee et al. (2014) find oil palm farmers to derive around one fourth of their total household income through non-oil palm related activities. There is no difference across adopters and non-adopters with respect to the number of livestock units owned by a household. While agricultural income constitutes the main share of total household income for both groups, adopters derive a larger share of total household income through farm activities.

\footnotetext{
${ }^{16}$ These households showed large deviations (>3 standard deviations) from standardized means of total consumption expenditures, non-food expenditures, food expenditures and calorie consumption levels. They further differed significantly from the remaining households with respect to a set of socio-economic and farm characteristics.

${ }^{17}$ The number of non-adopters is slightly larger compared to Chapter 2 because 14 farmers are managing immature or damaged oil palm parcels that do not produce FFB. These farmers are considered as non-adopters in this Chapter. In all following tables and statistical models, the group of adopters will only include farmers who maintain oil palm in a productive stage.
} 
Table 3.1. Descriptive statistics for oil palm adopters and non-adopters.

\begin{tabular}{|c|c|c|c|}
\hline & $\begin{array}{l}\text { Adopters } \\
(n=199)\end{array}$ & $\begin{array}{c}\text { Non-adopters } \\
(n=465)\end{array}$ & $\begin{array}{c}\% \text { difference } \\
\text { over non-adopters }\end{array}$ \\
\hline \multicolumn{4}{|l|}{ Farm endowments and agricultural activities } \\
\hline Cultivated area (ha) & $4.6(3.6)$ & $3.1(3.1)$ & $48^{* * *}$ \\
\hline Productive oil palm area (ha) & $1.9(1.9)$ & 0 & -- \\
\hline Households cultivating rubber (\%) & 57 & 93 & $-39^{* * *}$ \\
\hline Productive rubber area (ha) & $1.4(2.2)$ & $2.1(2.6)$ & $-33^{* * *}$ \\
\hline Livestock units (number owned by household) & $0.8(3.1)$ & $0.7(2.1)$ & 14 \\
\hline Share of farm income in total income (\%) & $71.4(44.8)$ & $66.3(50.0)$ & $5.1^{* * *}$ \\
\hline \multicolumn{4}{|l|}{ Off-farm income activities } \\
\hline \multicolumn{4}{|l|}{$\begin{array}{l}\text { Share of households with at least one member } \\
\text { engaged in... }\end{array}$} \\
\hline Employed activities (\%) & 39 & 49 & $-20^{* * *}$ \\
\hline Self-employed activities (\%) & 23 & 18 & 28 \\
\hline \multicolumn{4}{|l|}{ Other socio-economic characteristics } \\
\hline Age of household head (years) & $46.0(12.5)$ & $45.6(12.1)$ & 1 \\
\hline Household size (number of AE) & $3.0(1.0)$ & $3.0(1.0)$ & 0 \\
\hline Education (years of schooling) & $7.7(3.6)$ & $7.3(3.6)$ & $5^{* * *}$ \\
\hline $\begin{array}{l}\text { Household head migrated to place } \\
\text { of residence (dummy) }\end{array}$ & 71 & 46 & $54^{* * *}$ \\
\hline $\begin{array}{l}\text { Household head originates } \\
\text { from Sumatra (dummy) }\end{array}$ & 37 & 58 & $-36^{* * *}$ \\
\hline Distance to nearest market place $(\mathrm{km})$ & $5.7(7.2)$ & $7.0(7.5)$ & $-12^{* * *}$ \\
\hline
\end{tabular}

Notes: Mean values are shown with standard deviations in parenthesis. Oil palm adoption only includes farmers cultivating productive oil palm plots. ${ }^{* * *}$ indicates that the differences are statistically significant at the 1\% level. US Dollar =9,387 IDR in 2012 (World Bank, 2015).

With respect to off-farm income sources, adopters are found to be engaged in employment activities to a lesser extent than non-adopters. Nonetheless, they are engaged more frequently in self-employment activities, such as trading, or managing a shop or restaurant. With respect to socio-economic characteristics, adopters do not differ from non-adopters in terms of age of the household head or the size of the household. Adopters are slightly better educated and many have migrated to the study villages with out-of-Sumatra origin. This is not surprising, as early oil palm diffusion was associated with government-supported trans-migration programs that brought a large number of Javanese migrants to Sumatra (Zen et al., 2006). Adopters tend to live closer to such market places where daily food- and non-food items are purchased. 


\subsubsection{LAND USE PROFITABILITY}

The potential differences between oil palm and rubber plantations with respect to agronomic management practices as well as the levels of capital and labor use for cultivation were already mentioned in the previous section. Descriptive statistics suggest that oil palm adopters have larger farms and obtain a greater share of income from agriculture. Figure 3.1 and Table 3.2 explore such differences more comprehensively. Figure 3.1 shows realized gross margins (sales revenues less material input and hired labor costs) for oil palm and rubber plantations over the plantation life cycle. Thereafter, oil palm does not offer higher returns to land when compared to rubber plantations.

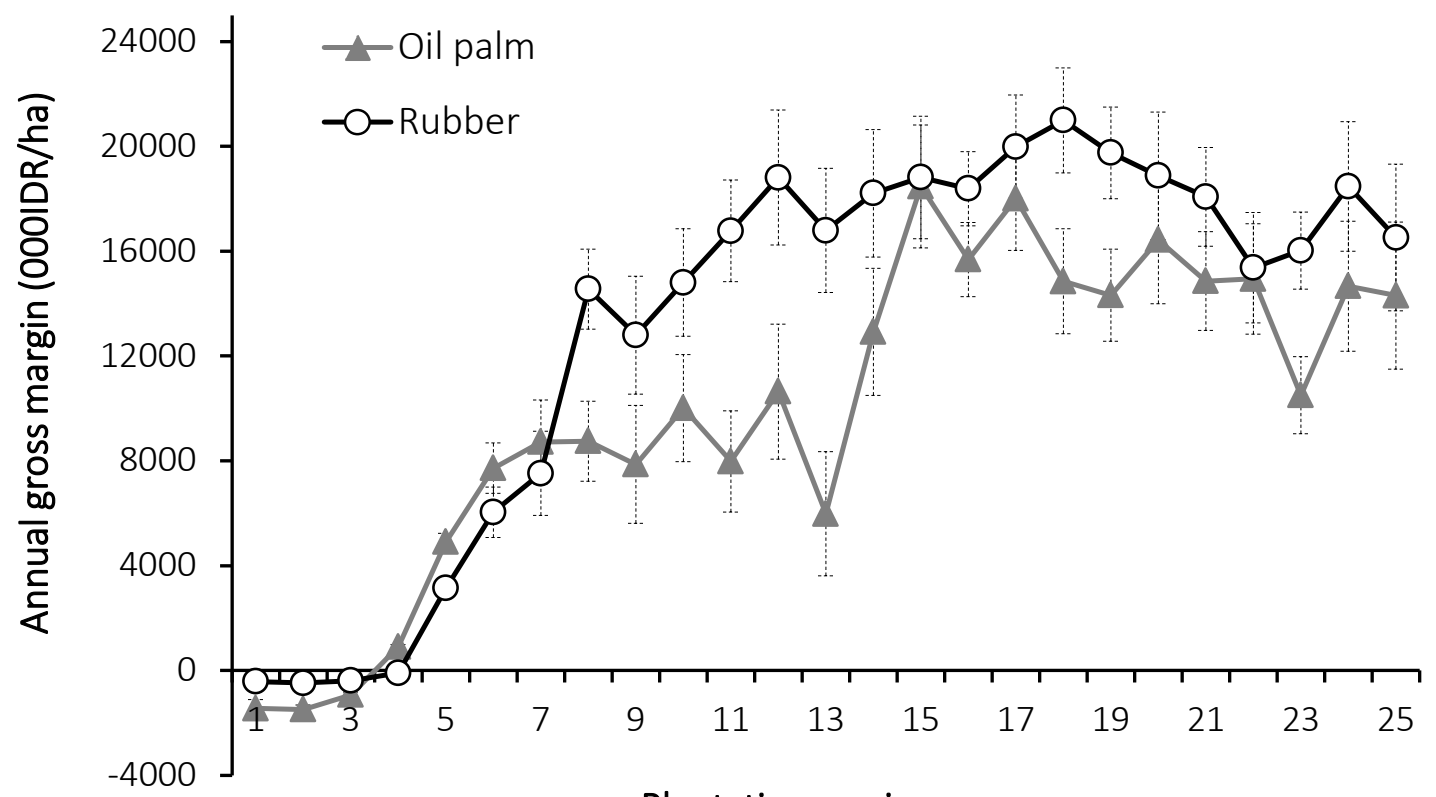

\section{Plantation age in years}

Figure 3.1. Annual gross margins for oil palm and rubber plantations over plantation age. Gross margins are recorded in thousand Indonesian Rupiah (000 IDR). Bars indicate standard errors. 1US Dollar = 9,387 IDR in 2012 (World Bank, 2015). Source: Household survey, 2012.

However, oil palm requires considerably lower levels of labor input, which translates into significantly higher returns to labor throughout the entire productive plantation life (Table 3.2). These findings are also supported by Feintrenie et al. (2010) and Rist et al. (2010). Thus, it can be assumed that the adoption of oil palm generally enables households to obtain similar returns to land compared to rubber farming, while 
they are able to save a significant amount of family labor, which can be invested in alternative farm and off-farm activities.

Table 3.2. Annual labor use and returns to labor for oil palm and rubber plantations.

\begin{tabular}{|c|c|c|c|c|c|c|}
\hline \multirow[b]{2}{*}{$\begin{array}{l}\text { Plantation } \\
\text { age (years) }\end{array}$} & \multicolumn{3}{|c|}{ Oil palm } & \multicolumn{3}{|c|}{ Rubber } \\
\hline & $\begin{array}{l}\text { Number } \\
\text { of plots }\end{array}$ & $\begin{array}{c}\text { Annual labor } \\
\text { use } \\
\text { (days/ha) }\end{array}$ & $\begin{array}{c}\text { Returns } \\
\text { to labor } \\
\text { (000 } \\
\text { IDR/day) }\end{array}$ & $\begin{array}{l}\text { Number } \\
\text { of plots }\end{array}$ & $\begin{array}{l}\text { Annual labor } \\
\text { use (days/ha) }\end{array}$ & $\begin{array}{l}\text { Returns to } \\
\text { labor } \\
\text { (000 } \\
\text { IDR/day) }\end{array}$ \\
\hline $6-15$ & 168 & $29(17)$ & 460 (450) & 323 & $119^{* * *}(106)$ & $105^{* * *}(198)$ \\
\hline $16-25$ & 67 & $32(14)$ & $672(481)$ & 296 & $136^{* * *}(83)$ & $164^{* * *}(128)$ \\
\hline$>25$ & 2 & $29(9)$ & 427 (169) & 158 & $120^{* * *}(72)$ & $147^{* * *}(131)$ \\
\hline Overall & 363 & $25(20)$ & 289 (544) & 947 & $106^{* * *}(94)$ & $95^{* * *}(190)$ \\
\hline
\end{tabular}

\subsection{AnALYtical FRAMEWORK}

\subsubsection{DEPENDENT VARIABLES}

The present study involves an array of dependent variables, viz. annual food and non-food consumption expenditure, daily calorie consumption, and daily calorie consumption from nutritious foods. Household consumption expenditures are measured in thousand Indonesian Rupiah (000 IDR), calorie consumption in kilo calories (kcal). In order to enhance comparability across households, all variables were converted to per adult equivalents $(A E)$, which was constructed following the OECD equivalent scale (OECD, 1982).

To record households' food expenditure details, the household members in charge of food purchases (often female) were asked to recall the quantities and prices of 132 different food items consumed during the past seven days preceding the interview. Items were checked one by one. Food consumption included market purchases, home production and meals taken outside the household. If quantities were reported in local units, appropriate conversions to liter or kilograms were made. If a food item was consumed from home production, prices were imputed using average market prices as paid by other households residing in the same village. 
Energy contents and nutritional composition of all food items were derived from national food composition tables as developed by the Sustainable Micronutrient Interventions to Control Deficiencies and Improve Nutritional Status and General Health in Asia (SMILING) project. ${ }^{18}$ If a particular food item was not listed in the SMILING database, food composition tables from the database of Food-standards, a bi-national government agency based in Australia and New Zealand, or the United States Department of Agriculture were used. ${ }^{19}$ Along with total energy consumption, we estimated the consumption of calories from highly nutritious foods. These items include seafood and animal products, fruits and vegetables, as well as pulses and legumes. In contrast to cereals and tubers, these items contain relatively more protein and micronutrients and are therefore used to reflect dietary quality of households (Babatunde and Qaim, 2010).

Non-food consumption expenditure was divided into 56 items, including items for basic needs such as housing, education, health related expenses, clothing, private and public transportation, etc. In addition, a number of luxurious consumption items such as electronic equipment, cosmetics, club membership fees, celebrations, and recreational expenses were covered. Expenditures were recorded based either on annual or on monthly recall, according to the frequency of consumption.

Table 3.3 presents details of dependent variables in the livelihood impact analysis along with a number of nutritional indicators. Total annual consumption expenditures are found to be well above the regional poverty line (3.24 million IDR per capita per year for 2012 for rural Jambi province; BPS, 2014). ${ }^{20}$ These figures are in line with the Food Security and Vulnerability Atlas for Indonesia which reports the incidence of poverty to be below 10\% in Bungo, Tebo and Muaro Jambi, and between $15-20 \%$ in

${ }^{18}$ Cf. Berger et al. (2013) for details on the SMILING project. Food composition tables were retrieved on 20 November 2014 from http://www.nutrition-smiling.eu/content/view/full/48718. 19 Food nutrient databases were retrieved on 20 November 2014 from http://www.foodstandards.gov.au/science/monitoringnutrients/ausnut/ausnutdatafiles/Pages/f oodnutrient.aspx (Food-Standards), and http://ndb.nal.usda.gov/(USDA).

${ }^{20}$ The annual per capita consumption expenditure of sample households is 10.54 million IDR (12.09 million IDR for adopters and 9.87 million IDR for non-adopters). 
Sarolangun and Batanghari (DKP et al., 2009). Average non-food expenditures are slightly larger than food expenditures. Consumption expenditures are significantly higher for oil palm adopters across all expenditure categories with non-food expenditures surpluses being relatively larger than surpluses in food expenditures. Arguably, additional income from oil palm adoption might be allocated to non-food consumption by farmer households.

Table 3.3. Descriptive statistics for household consumption expenditure and calorie consumption by adoption status.

\begin{tabular}{|c|c|c|c|}
\hline & $\begin{array}{l}\text { Oil palm adopters } \\
\qquad(\mathrm{n}=199)\end{array}$ & $\begin{array}{l}\text { Non-adopters } \\
\quad(n=465)\end{array}$ & $\begin{array}{c}\% \text { difference } \\
\text { over non-adopters }\end{array}$ \\
\hline \multicolumn{4}{|l|}{ Consumption expenditure } \\
\hline $\begin{array}{l}\text { Total annual consumption expenditure } \\
\text { (million IDR/AE) }\end{array}$ & $16.72(8.88)$ & $13.40(8.04)$ & 25 \\
\hline $\begin{array}{l}\text { Annual non-food expenditure } \\
\text { (million IDR/AE) }\end{array}$ & $9.52(7.84)$ & $7.08(6.67)$ & 34 \\
\hline $\begin{array}{l}\text { Annual food expenditure } \\
\text { (million IDR/AE) }\end{array}$ & $7.21(2.92)$ & $6.32(2.79)$ & 14 \\
\hline $\begin{array}{l}\text { Share of food expenditure } \\
\text { (\% of total expenditure) }\end{array}$ & $48(15)$ & $51(14)$ & -6 \\
\hline \multicolumn{4}{|l|}{ Calorie consumption and dietary quality } \\
\hline Daily calorie consumption (kcal/AE) & $3,257(1240)$ & $2,889(1,150)$ & 13 \\
\hline $\begin{array}{l}\text { Daily calorie consumption form } \\
\text { nutritious foods (kcal/AE) }\end{array}$ & $1,236(719)$ & $995(612)$ & 24 \\
\hline Share of calories from nutritious foods & $37(12)$ & $33(12)$ & 12 \\
\hline Number of food items & $29.4(8.1)$ & $26.2(7.6)$ & 12 \\
\hline Number of food groups & $10.7(1.1)$ & $10.3(1.4)$ & $<1$ \\
\hline
\end{tabular}

Notes: Mean values are shown with standard deviations in parenthesis. Oil palm adoption only includes farmers cultivating productive oil palm plots. All differences are statistically different at the 1\% level. 1 US Dollar = 9,387 IDR in 2012 (World Bank, 2015).

The daily calorie consumption for sample households is higher compared to the national average, which was around 1,900 kcal per capita in 2012 (BPS, 2015). ${ }^{21}$ Such figures are in line with findings from the Nutrition Map of Indonesia, which reports calorie consumption levels for Jambi province to be above the national average (MPW et al., 2006). Adopters are found consuming more total calories and more calories from

${ }^{21}$ The daily per capita calorie consumption of sample households is 2,195 kcal (2,364 kcal for adopters and 2,124 kcal for non-adopters). 
nutritious foods. They also stand superior with respect to the food variety score and the dietary diversity score. ${ }^{22}$ Apparently, adopters do not only increase their calorie consumption, but also improve their diets by consuming more diverse and nutritious foods.

\subsubsection{MODELING CONDITIONAL MEAN EFFECTS}

In this section, we specify a set of OLS models to estimate the effects of oil palm adoption on household consumption expenditures and calorie consumption. Formally, we specify the following models:

$$
Y_{i j}=\alpha+\gamma O P_{i j}+\sum_{l=1}^{L} \beta_{l} H_{i j}+\rho R_{i j}+\sigma V_{i}+\theta_{j} Z_{j}+\varepsilon_{i j}
$$

Here $Y_{i j}$ is the respective dependent variable recorded for the $\mathrm{i}^{\text {th }}$ household from the $j^{\text {th }}$ regency and $O P_{i j}$ is a dummy indicating whether a farmer cultivates productive oil palm plantations. As indicated in the previous subsection, the set of dependent variables includes total annual consumption expenditure, annual non-food consumption expenditure, annual food consumption expenditure, daily calorie consumption and daily calorie consumption from nutritious foods. $R_{i j}$ is the area under rubber plantations. The vector $H_{i j}$ contains other $L$ farm-household attributes including household size, the household head's age, education, migration status, ethnicity, distance from the market to the place of residence etc. $V_{i}$ captures the type of village a household resides in through a set of dummy variables indicating whether the village was founded under the roof of the government resettlement program, founded naturally by the local population, or whether the village is a mixture of both forms (with naturally founded villages as reference). In addition we control for non-random village selection into the sample. In order to capture general differences in infrastructure and economic development, $Z_{j}$ captures regency level fixed effects through a set of 4 regency

\footnotetext{
${ }^{22}$ The food variety score indicates the number of consumed food items; the dietary diversity score indicates the number of food groups from which food items are consumed (FAO, 2010).
} 
dummies (with Sarolangun regency as the reference). Further, $\beta_{l}, \gamma, \rho, \sigma$ and $\theta_{j}$ are the parameter vectors to be estimated and $\varepsilon_{i j}$ is the random error term with zero mean and constant variance. If specified correctly, $\gamma$ gives the conditional mean effect of oil palm adoption.

\subsubsection{QUANTILE REGRESSIONS MODEL SPECIFICATION}

The effects of oil palm adoption on consumption expenditure and calorie consumption might be heterogeneous among adopters due to differences in opportunities of farm size expansion and off-farm livelihood diversification. Simple OLS estimators cannot depict such nuances as they provide estimates of the effect of a given covariate on the conditional mean of the dependent variable.

One way of analyzing heterogeneity of effects is the specification of quantile regressions. Quantile regressions were first introduced by Koenker and Basset (1978) as a generalization of median regression to other quantiles. Quantiles of the conditional distribution of the response variable are expressed as functions of observed covariates (Koenker and Hallock, 2001). Instead of restricting covariate effects on conditional means, these regressions allow analyzing whether the effect of a given covariate changes over the conditional distribution of the dependent variable (Koenker and Hallock, 2001). Recent applications have used quantile regressions to model a range of heterogeneous effects from determinants of wages (Appleton et al., 2014), technology adoption (Sanglestsawai et al., 2014), social capital (Grootaert and Narayan, 2004) and $\mathrm{CO}_{2}$ emissions (You et al., 2015) to impacts of economic inequality (Hassine, 2015; Nguyen et al., 2007). The conditional quantile function of $y_{i}$ given $x_{i}$ can be expressed as

$$
Q_{\tau}\left(y_{i} \mid x_{i}\right)=x_{i} \beta_{\tau}
$$

With $Q_{\tau}\left(y_{i} \mid x_{i}\right)$ being the conditional quantile function at quantile $\tau$, with $0<\tau<1$ and $\beta_{\tau}$ the respective unknown vector of parameters. Parameters are obtained by minimizing: 


$$
\min _{\beta_{\tau}} \frac{1}{N}\left\{\sum_{i: y_{i} \geq x_{i} \beta_{\tau}} \tau\left|y_{i}-x_{i} \beta_{\tau}\right|+\sum_{i: y_{i}<x_{i} \beta_{\tau}}(1-\tau)\left|y_{i}-x_{i} \beta_{\tau}\right|\right\}
$$

This equation is solved by linear programming methods (Buchinsky, 1998). Equation (3.3) implies that coefficients can be estimated at any point of the conditional distribution of the dependent variable by asymmetrical weighing of absolute values of the residuals. We specify a set of quantile regressions for each of the previously introduced dependent variables. Quantile functions are estimated simultaneously at five different levels of the conditional distribution of the respective dependent variable $(\tau=$ $0.10,0.25,0.50,0.75,0.90)$. As covariates, we use the same vector of household and farm attributes as in the OLS regressions.

\subsubsection{ADDRESSING SELF-SELECTION BIAS WITH OIL PALM ADOPTION}

In the specification of econometric models, we need to account for the fact that oil palm adoption may not be a random process. As households self-select into the groups of adopters and non-adopters, the set of determinants could include unobserved factors (e.g., motivation, risk aversion etc.) that affect the decision to adopt oil palm and the outcome variables of interest simultaneously. Such unobserved heterogeneity could potentially result in biased estimates. For instance, highly motivated farmers might take up oil palm faster. At the same time, irrespective of oil palm adoption, these farmers might achieve higher yields and farm incomes as compared to non-adopters. One common approach to overcome endogeneity bias with dichotomous adoption variables is the use of treatment effects models, which provide unbiased estimates in the presence of selection bias (Greene, 2008). However, obtaining reliable estimates using the treatment effect framework requires at least a unique instrumental variable that determines the adoption decision, but not the outcome variable directly.

Previous studies have shown that oil palm adoption at the household level is positively influenced by a set of village and regional level attributes (Euler et al., 2015; Budidarsono et al., 2013). The probability of individual oil palm adoption is higher when 
contractual ties between farmer group(s) and a private or public firm are active at the village level. Such contracts are typically negotiated between farmers or farmer cooperatives, but not necessarily include all farmers from a village. Nevertheless, the presence of contracts improves the overall access to technical extension services and output processing facilities at the village level (Gatto et al., 2014), thereby increasing the probability of non-contract farmers to adopt oil palm. Further, although most of the sample farmers (94\%) started oil palm after 1992, the probability of adoption is found to be higher in villages where oil palm plantations have already been present in or before 1992 (Gatto et al., 2014). We therefore derive two instrumental variables -the presence of oil palm plantations in 1992 at the village level (recorded as dummy variable), and the presence of a farmer group-private investor contract at the village level. In order to enhance the variation among the sample households, we record the duration (number of years) for which a particular household was involved in farming while a village level contract was enacted ( 0 for villages with no contract) as the second instrument in the treatment effects models. Both of these variables are found strongly influencing the adoption decision.

The selected instruments were subjected to a falsification test to examine their validity that they are not directly correlated to the outcome variables. Following di Falco et al. (2011), the outcome variables were regressed on the instruments in a reduced model, only for the sub-group of non-adopters. Coefficient estimates are insignificant in all models, indicating that there is no second pathway through which instruments affect the outcome variables other than through oil palm adoption (Table A1). The results show statistical non-significance in the outcome model for non-adopters and hence it can be concluded that these variables are valid as instruments. The full treatment effects model estimates are provided in Appendix A (Tables A2 and A3).

After controlling for covariates, the null hypothesis of no-correlation between error terms of the selection and outcome equations (rho) is not rejected by the Wald test in any of the treatment effect models. This seems plausible as oil palm adoption is largely determined by regional factors such as infrastructural development and 
connectivity to palm oil mills and industrial plantations (Euler et al., 2015; Gatto et al., 2014). Only in less than $40 \%$ of the sample villages, oil palm and rubber coexist over significantly large landscapes. In the remaining majority, large areas are devoted for monocultures of either oil palm or rubber. It is therefore possible that farmer heterogeneity plays only a minor role in the adoption decision. Against this background, we proceed the analysis with a set of OLS models.

\subsection{RESULTS}

\subsubsection{EFFECTS OF OIL PALM ADOPTION ON HOUSEHOLD WELFARE}

Oil palm adopters have significantly higher non-food and food expenditures, and they consume more calories, as already observed in the descriptive statistics. However, we need to control for possible confounding factors before attributing the observed differences to oil palm cultivation. Table 3.4 presents estimation results for the model specification as outlined in equation (3.1).

We start with analyzing the effects of oil palm adoption on consumption expenditures which are given in the first three columns. The results suggest that oil palm cultivation significantly enhances total consumption expenditure (by around 3.4 million IDR), non-food expenditure (by around 2.6 million IDR) and food expenditure (by around 0.9 million IDR) of the household. In percentage terms this corresponds to around $25 \%$ over the total consumption expenditure of non-adopters, $37 \%$ over the non-food consumption expenditure, and $14 \%$ over the food consumption expenditure. If we

assume that consumption expenditures are enhanced with rising farm income, these findings are in line with observations made by Rist et al. (2010) and Feintrenie et al. (2010) who reported positive income effects of oil palm cultivation mainly through increased labor productivity. Building on descriptive analysis, Budidarsono et al. (2012) also found household incomes to increase with oil palm cultivation. 


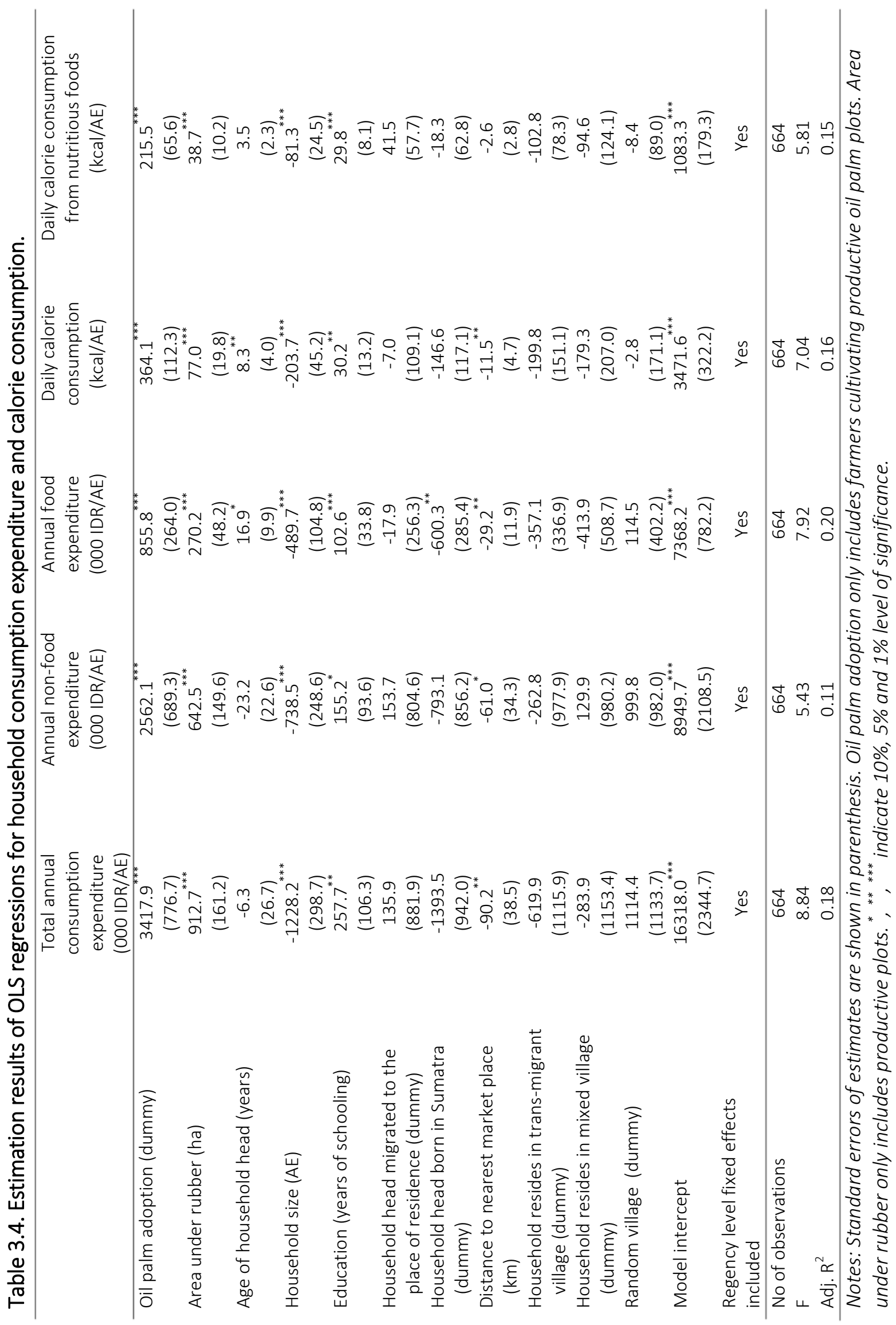


Since we control for the total area under rubber plantations, the oil palm adoption dummy captures the effect of oil palm cultivation in addition to the mean cultivated rubber area. Recalling the reported levels of returns to land for oil palm and rubber plantations, the livelihood effect of oil palm adoption might partly be the scale effect stemming from farm size expansion. This notion is supported by additional regression results with alternative model specifications with respect to oil palm area and total farm size. If we insert the area under oil palm along with the area under rubber plantations, we find equal sized coefficients for both crops across all models, indicating that their effects on consumption expenditure are very similar (cf. Table A4).

However, oil palm demands significantly lower labor input, and therefore potentially enables farm size expansion and income diversification through the release of family labor. For example, if oil palm adoption is included alongside total farm size (Table 3.5), the effects of oil palm adoption on total consumption expenditure and nonfood expenditure are reduced by half, whereas the effect on food expenditure turns insignificant. Additionally controlling for annual household off-farm income and the number of owned livestock units, the positive effects of oil palm adoption on expenditures are further reduced with the coefficients for non-food expenditure and food-expenditure becoming insignificant (cf. Table A5). These results suggest that the main pathways through which oil palm adoption affects household consumption expenditures is via farm size expansion, diversification of on farm production (including livestock) and intensification of off-farm income activities. We find the effect of oil palm adoption to be more pronounced on non-food expenditures than on food expenditures. Potentially, adopters have reached saturation levels with respect to calorie intakes where further consumption of food items seems less valuable for them.

With respect to household nutrition, descriptive statistics have shown a surplus of total calorie consumption and a higher share of calories derived from nutritious foods for the group of oil palm adopters. The last two columns of Table 3.4 present the regression results with calorie consumption and calorie consumption from nutritious foods as dependent variables. Oil palm is found to significantly increase overall calorie 
consumption (by $364 \mathrm{kcal}$ ) as well as calorie consumption from nutritious foods (by 216 kcal). In percentage terms this corresponds to around $13 \%$ over the total calorie consumption of non-adopters, and to around $22 \%$ over the calorie consumption from nutritious foods. Thus, the estimated positive effect of oil palm adoption for food expenditure does not only translate into higher overall levels of calorie consumption, but also enhances a more nutritious diet among adopters. Apparently, non-food cash crop production is not associated with deteriorating household nutrition. Most likely, local food markets seem to be well developed and are able to supply an adequate amount and diversity of food items. Functioning food markets have been identified as critical condition allowing income surpluses to be translated into richer diets (Jones et al., 2014; von Braun, 1995).

As in the case of household consumption expenditure, the positive effects of oil palm adoption are reduced in the alternative model specifications (Tables 3.5 and A5). However, coefficient estimates remain significant, even after controlling for total farm size and off-farm income. Since $57 \%$ of oil palm adopters also cultivate rubber, market risk faced by farmers might be spread, enabling a more stable consumption especially of food items.

Included covariates are found to have similar effects across all models. Thereafter, increasing the area under rubber cultivation by one additional hectare has positive effects on household expenditures and calorie consumption. This is not a surprise, as rubber plantations are also important sources of cash income (Rist et al. 2010; Feintrenie et. al, 2010). Larger households tend to have lower expenditure levels and tend to reduce both total calorie consumption and intake of energy from nutritious foods. This finding is consistent with other studies (Qaim and Kouser, 2013; Babatunde and Qaim, 2010). Most likely, economies of scale in the preparation and consumption of food are associated with lower levels of food wastage in larger families. Thus, lower energy availability might not necessarily mean lower calorie consumption (Babatunde and Qaim, 2010). Education levels are positively associated with consumption expenditures, calorie intakes and calorie intake from nutritious foods. Qaim and Kouser 
(2013) also find positive nutrition effects of rising education levels, while Babatunde and Qaim (2010) find negative effects. In the context of our study, better education might be correlated to higher farm incomes through better agronomic management practices. A larger distance between the place of residence and the next market place for food and non-food purchases has negative effects on consumption expenditure, total calorie consumption, but surprisingly not on calorie consumption from nutritious foods. Most likely, remoteness to commercial centers decreases the availability of consumption items. However, certain food items might be supplied from local production, especially fruits and certain vegetables. Households of Sumatran origin tend to spend less on food consumption, possibly due to of a higher share of subsistence production or heavier reliance on natural resources such as fish and fruits.

Table 3.5. Estimation results of OLS regressions for household consumption expenditure and calorie consumption with alternative model specifications.

\begin{tabular}{|c|c|c|c|c|c|}
\hline & $\begin{array}{l}\text { Total annual } \\
\text { consumption } \\
\text { expenditure } \\
\text { (000 IDR/AE) }\end{array}$ & $\begin{array}{l}\text { Annual non- } \\
\text { food } \\
\text { expenditure } \\
\text { (000 IDR/AE) }\end{array}$ & $\begin{array}{l}\text { Annual food } \\
\text { expenditure } \\
\text { (000 IDR/AE) }\end{array}$ & $\begin{array}{c}\text { Daily calorie } \\
\text { consumption } \\
(\text { kcal/AE })\end{array}$ & $\begin{array}{c}\text { Daily calorie } \\
\text { consumption } \\
\text { from nutritious } \\
\text { foods (kcal/AE) }\end{array}$ \\
\hline $\begin{array}{l}\text { Oil palm } \\
\text { adoption } \\
\text { (dummy) }\end{array}$ & $\begin{array}{l}1628.17^{* *} \\
(773.09)\end{array}$ & $\begin{array}{l}1256.19^{*} \\
(674.04)\end{array}$ & $\begin{array}{c}372.02 \\
(265.82)\end{array}$ & $\begin{array}{l}225.65^{* *} \\
(113.15)\end{array}$ & $\begin{array}{c}154.95^{* *} \\
(68.43)\end{array}$ \\
\hline $\begin{array}{l}\text { Total farm size } \\
\text { (ha) }\end{array}$ & $\begin{array}{l}737.79^{* * *} \\
(114.57)_{* * *}\end{array}$ & $\begin{array}{l}543.92^{* * *} \\
(99.01)_{* * *}\end{array}$ & $\begin{array}{c}193.87^{* * *} \\
(41.28)\end{array}$ & $\begin{array}{l}55.54^{* * *} \\
(17.21)_{* * *}\end{array}$ & $\begin{array}{c}23.12^{* * *} \\
(8.19)_{* * *}\end{array}$ \\
\hline $\begin{array}{l}\text { Model } \\
\text { intercept }\end{array}$ & $\begin{array}{c}16663.10^{* * *} \\
(2262.61)\end{array}$ & $\begin{array}{l}9163.32^{* * *} \\
(2045.16)\end{array}$ & $\begin{array}{c}7499.71^{* * *} \\
(769.15)\end{array}$ & $\begin{array}{c}3508.74^{* * *} \\
(319.47)\end{array}$ & $\begin{array}{c}1107.77^{* * *} \\
(178.65)\end{array}$ \\
\hline $\begin{array}{l}\text { Regency level } \\
\text { fixed effects } \\
\text { included }\end{array}$ & Yes & Yes & Yes & Yes & Yes \\
\hline $\begin{array}{l}\text { No. of } \\
\text { observations }\end{array}$ & 664 & 664 & 664 & 664 & 664 \\
\hline $\mathrm{F}$ & 8.96 & 5.94 & 7.25 & 6.47 & 5.41 \\
\hline Adj. $R^{2}$ & 0.19 & 0.12 & 0.19 & 0.16 & 0.14 \\
\hline
\end{tabular}

Notes: Standard errors are shown in parenthesis. Additional covariates used in the model correspond to the previous OLS models presented in Table 3.4. ${ }^{*},{ }^{* *},{ }^{* * *}$ indicate $10 \%, 5 \%$ and $1 \%$ level of significance testing that coefficients are equal to zero.

\subsubsection{IMPACT HETEROGENEITY AMONG ADOPTERS}

In this sub-section, we examine whether the effect of oil palm cultivation is homogeneous among adopters. OLS regression results suggest positive mean effects of oil palm adoption on consumption expenditure, calorie consumption and dietary quality. 
However, results also imply that effects are in part driven by the scale of agricultural operations, rather than by the adoption of oil palm per se. Thus, the net economic benefits associated with oil palm adoption depend on farm and household attributes such as the level of total plantation area which is likely to be higher at the upper quantiles of the conditional distributions of the set of dependent variables.

Quantile regressions allow to test whether the effect of oil palm cultivation differs between adopters at the conditional bottom quantile $(\tau=0.10)$ and adopters at the conditional top quantile $(\tau=0.90)$ of the distribution of the dependent variable. Results of quantile estimates are presented in Figures 3.2 (a) to (e). We restrict the presentation to the effect of oil palm adoption. Each Figure corresponds to the estimation results for one dependent variable. Table 3.6 provides the Wald test statistic for the test for equality of slope parameters for different pairs of quantiles. If the estimated coefficients differ across quantiles, it can be assumed that the effect of oil palm adoption is not constant across the distribution of the respective dependent variable (Koenker and Hallock, 2001). More detailed quantile estimates are included in Appendix A (Tables A7 to A11). 

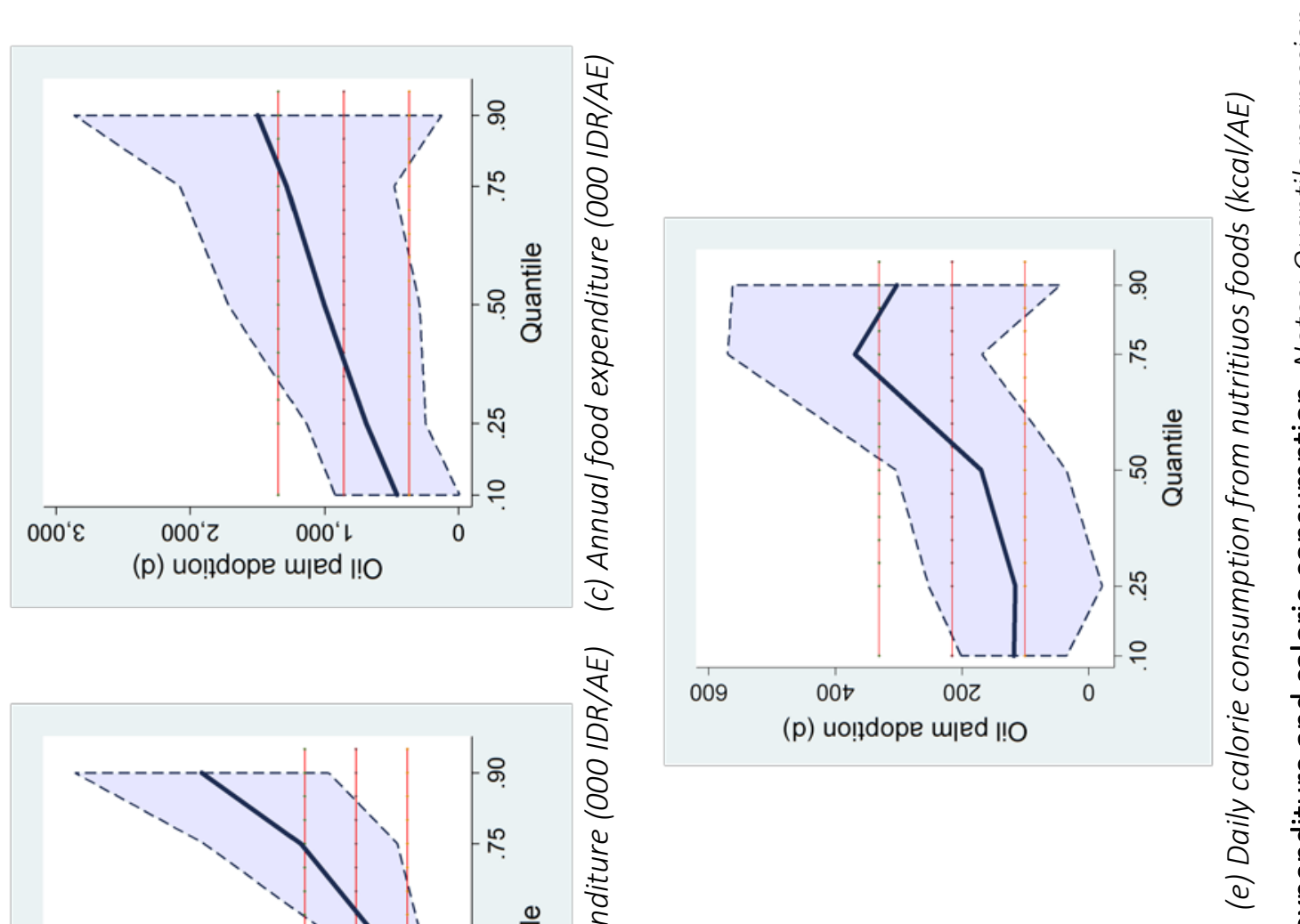

$\frac{5}{\mathrm{c}}$

जे है
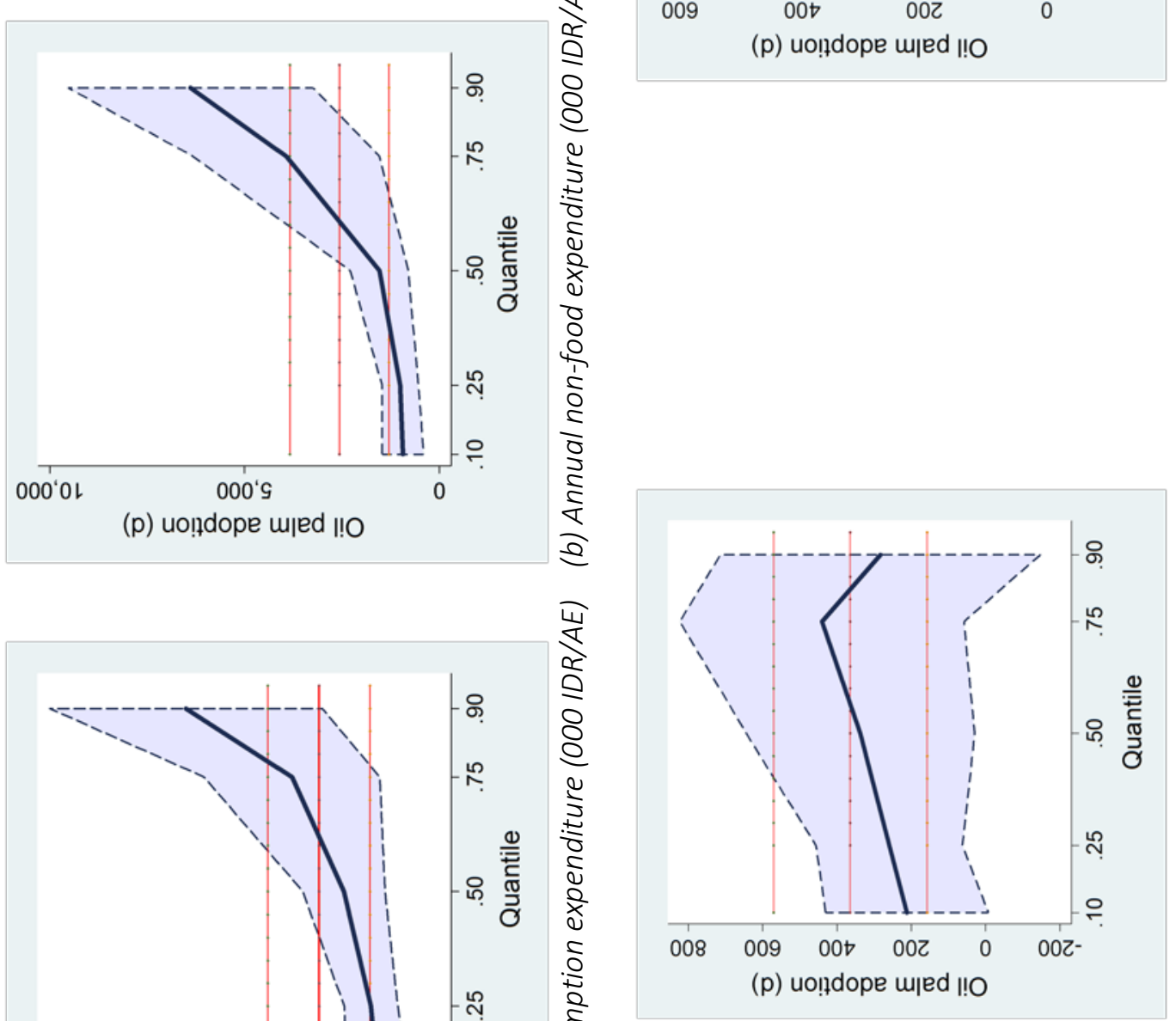

का ज्ञ

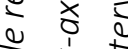

$\stackrel{5}{x}+$

ธิ

ธ ธิ อ

क्षे

$\sum \frac{8}{2}$

ᄃं $\frac{8}{0}$

은

空

ติ

ठำ

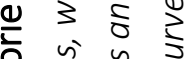

눵 ज

व है

के

总

운

ลे ษัँ

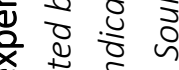

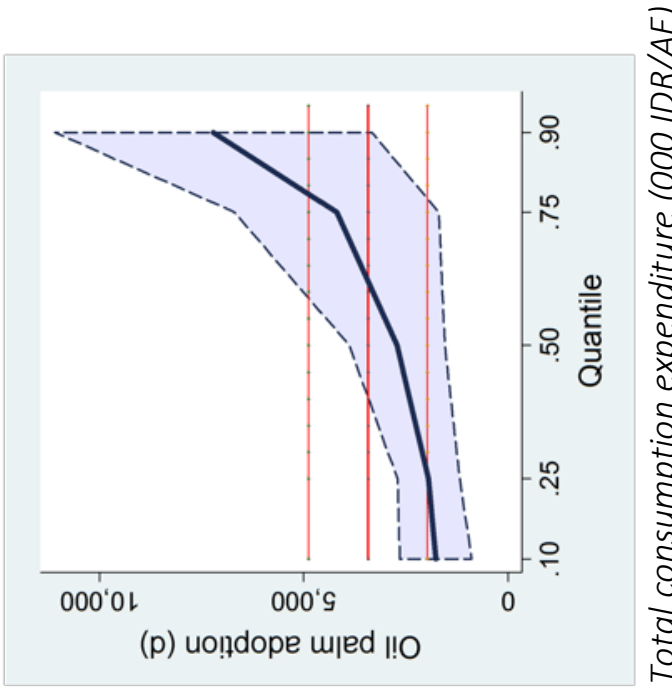

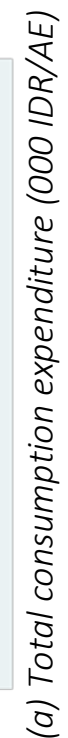

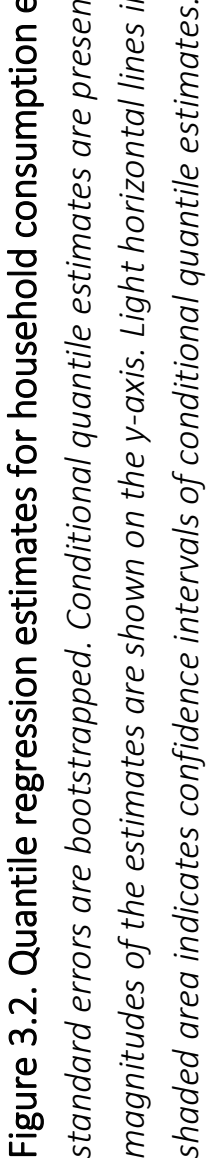


Figures 3.2 (a) to (c) depict the conditional quantile effects of oil palm adoption on household consumption expenditure. Oil palm adoption is found to have positive effects on total consumption expenditure, non-food and food expenditure across all quantiles. However, adoption effects on non-food expenditure are distributed unevenly with oil palm adoption increasing the 0.90 quantile significantly stronger compared to the 0.10 quantile. Thus, oil palm adoption might enhance non-food expenditure disparities (Table 3.6 and Table A7). Additional model specifications suggest that the effect of adoption and its heterogeneity are reduced across all quantiles if total farm size, total annual off-farm income and the number of livestock units owned by the household are controlled for (Table A11). However, while the quantile estimate for oil palm adoption is smaller in magnitude it is still significantly larger at the 0.90 quantile compared to the 0.10 and 0.50 quantile. Most likely, some unobserved characteristics like farming ability seem to contribute to the observed heterogeneity of adoption effects. Quantile estimates for the effects on food expenditure are found to follow a similar pattern. In contrast to non-food expenditure, these effects do not differ across quantiles. Thus, oil palm adoption exerts a homogeneous effect on food expenditure along the entire distribution of food expenditures. Potentially, adopters at the 0.90 quantile are saturated with respect to food consumption and tend to invest additional expenditures for the consumption of non-food items more frequently.

Figures 3.2 (d) and (e) present the effects of oil palm adoption on calorie consumption and calorie consumption from nutritious foods. The nutritional effects of oil palm adoption are positive and consistent across the group of adopters. However, oil palm adoption does not seem to contribute to disparities in calorie consumption and dietary quality (Table 3.6, Table A9 and A10). This could be related to the relative high calorie consumption levels and the high share of nutritious food items that is consumed by all of our sample farmers. Moreover, heterogeneity in calorie consumption might not mainly be driven by income related variables, but rather by socio-economic household attributes such as education levels and levels of physical activity. 
Table 3.6. Wald-test for equality of conditional slope parameters across quantiles.

\begin{tabular}{|c|c|c|}
\hline & \multicolumn{2}{|c|}{$\begin{array}{l}\text { Wald test } F \text { statistic: } \\
\quad \tau=0.90 \text { against... }\end{array}$} \\
\hline & $\tau=0.10$ & $\tau=0.50$ \\
\hline Total consumption expenditure (000 IDR/AE) & $5.08(0.02)$ & $1.72(0.19)$ \\
\hline Non-food expenditure (000 IDR/AE) & $5.79(0.02)$ & $1.73(0.19)$ \\
\hline Food expenditure (000 IDR/AE) & $2.40(0.12)$ & $2.54(0.11)$ \\
\hline Calorie consumption (kcal/AE) & $0.08(0.77)$ & $0.74(0.39)$ \\
\hline Calorie consumption from nutritious foods (kcal/AE) & $1.37(0.24)$ & $0.47(0.49)$ \\
\hline
\end{tabular}

Notes: Corresponding p-values are given in parenthesis. Equality of marginal effects is tested for $\tau=0.10$ and $\tau=0.50$ against $\tau=0.90$. The variance-covariance matrix for each quantile regression is obtained via bootstrapping (250 replications with replacement).

\subsection{CONCLUSIONS}

Oil palm is one of the most rapidly expanding crops throughout the humid tropics. Recent expansion of oil palm plantations is largely driven by smallholder farmers. Nevertheless, there has only been limited empirical evidence about the socioeconomic implications of oil palm adoption and associated land use changes. The present study has contributed to the existing literature by analyzing the effects of oil palm cultivation on households' economic welfare and nutritional status using household survey data from Jambi province, Indonesia. We have estimated average welfare and nutrition effects of oil palm cultivation for adopting smallholders. In addition, it was assessed whether observed effects are heterogeneous among oil palm adopters using quantile regressions. The analysis shows that oil palm is a financially lucrative land use option for smallholder farmers. Results suggest that its cultivation is associated with increases in household consumption expenditure, calorie consumption and dietary quality.

However, the observed effects can mainly be attributed to farm size expansions and off-farm income increases that are facilitated with the adoption of oil palm, and not to oil palm adoption per se. Due to the labor-saving and capital-intensive management of the crop, farmers are able to cultivate a relatively larger plantation area compared to traditional land uses at a given level of family labor. The net livelihood outcome of oil palm adoption therefore depends on smallholder household attributes which define 
their access to factor markets. Variation in these attributes is likely to cause livelihood outcomes to be distributed unequally among adopters. Although positive effects of oil palm adoption are present along the entire distribution of the set of dependent variables under study, the effects on household non-food expenditure are found to be significantly stronger at the upper tail of respective distributions.

There are two major policy implications that the present study addresses. First, the diffusion of oil palm among smallholder farmers may worsen social inequality. Among the group of oil palm adopters, those with better access to land and capital will realize significantly larger economic benefits compared to the resource constrained ones. From a rural development perspective, oil palm expansion might ultimately become a race for land, which might become a speculative object and a scare resource. Especially more traditional land use practices, such as slash and burn farming or rubber agro-forests, might gradually be replaced with the diffusion of oil palm plantations into smallholder agriculture. Thus, farmers who depend on more traditional livelihoods and who are not able (or willing) to make the transition to more intensive forms of smallholder agriculture are potential losers of this transformation process.

Second, the financial effects of oil palm cultivation forms a major element in the economic incentives that smallholders have to encroach forest land in Jambi and other parts of Indonesia. Due the positive livelihood outcomes associated with oil palm cultivation, an increasing number of smallholders is likely to include oil palm in their crop portfolio. Especially in regions that are still dominated by extensive land use practices, the land rent of agriculture relative to extensive agriculture (e.g., rubber agroforests) and forests could be increased (Krishna et al., 2014). Ceteris paribus, this might not only lead to increased deforestation but also adversely affect the long-term tenability of conservation incentives (Phelps et al., 2013). Imprecisely defined land rights further complicate the scenario and hamper foreseeing the exact social and environmental implications of oil palm expansion in Indonesia. Making land use transformation systems more sustainable and inclusive could be one of the most daunting challenges for policy makers and empirical researchers alike. 


\title{
CHAPTER 4: EXPLORING YIELD GAPS IN SMALLHOLDER OIL PALM PRODUCTION SYSTEMS
}

\begin{abstract}
Oil palm (Elaeis guineensis) has become the most important oil crop throughout the world. Its expansion has, however, raised serious environmental and social concerns. Increasing yields on existing plantations is a potential pathway to reduce the undesired ecological impacts of oil palm expansion and to enhance the social benefits of oil palm production. Although oil palm production is still dominated by private sector companies, smallholders are increasingly engaging in its cultivation, but studies on smallholders' agronomic performance are scarce. Based on crop modelling analysis and quantitative household survey data from Sumatra, Indonesia, this chapter quantifies smallholder yield gaps relative to exploitable yield levels and analyses smallholders' major production constraints. We find that oil palm smallholdings offer a tremendous potential for future yield increases, because they obtain only $56 \%$ of the cumulative exploitable yields over a 20 year plantation life cycle. Important determinants of yield gaps are management practices such as fertilizer dosage and length of harvesting intervals. Furthermore, supported smallholders achieve higher yields compared to independent smallholders. Some policy implications are discussed.
\end{abstract}

\subsection{INTRODUCTION}

The increasing demand for vegetable oils and biofuels has led to a rapid expansion of oil palm production. During the last two decades the area under oil palm has increased three-fold and the production of Crude Palm Oil (CPO) has increased more than four-fold (FAOSTAT, 2014). This trend will likely continue in the next decades as the demand for vegetable oil is expected to double by 2050 (Corley, 2009). Especially in Indonesia and Malaysia, the world's largest and second largest palm oil producers contributing over $85 \%$ of the total world production (FAOSTAT, 2014), oil palm expansion has caused massive forest clearance in the past and is expected to contribute to future deforestation and environmental degradation (Margono et al., 2014; Wilcove 
and Koh, 2010; Buttler and Laurence, 2009). If future palm oil demand is to be met in an environmentally sound manner, there is an urgent need to increase yields in existing oil palm production systems and hence sparing forest resources.

Although palm oil production is still dominated by private sector companies, smallholder farmers are increasingly engaging in oil palm production (Feintrenie and Levang, 2009; Vermeulen and Goad, 2006) and are expected to outnumber the private sector in both production and area under cultivation in the future (Feintrenie and Levang, 2009). However, smallholder yields show large variations and are often far below plantation standards (World Bank, 2011; Vermeulen and Goad, 2006; Hartemik, 2005; Corley and Tinker, 2003). While the national average oil palm yields are 21 and 17 tons Fresh Fruit Bunches (FFB)/ha for Malaysia and Indonesia (FAOSTAT, 2014), the average yields of Indonesian smallholders are reported to be around 11.1 tons FFB/ha (BPS, 2015). Within the estate sector, in contrast, plantations in favourable sites often reach yields of more than 30 tons $\mathrm{FFB} / \mathrm{ha}$. Single blocks, the smallest management unit (<25 ha) frequently report yield levels of over 40 tons FFB/ha, which are confirmed by field trials under optimum management conditions (Donough et al., 2009). As opposed to the private sector, smallholders face a set of agronomic and institutional constraints that hinder the achievement of the crops full production potential (Cramb, 2013). These constraints include the use of poor planting material, inadequate dosage and application of fertilizers, as well as overlong harvesting cycles (Corley and Tinker, 2003).

Despite their growing importance and relative poor performance, smallholder farmers have received little attention in the literature on oil palm production. A few recent studies looked at the profitability of smallholder oil palm production in Malaysia and in Indonesia using gross margin analysis (Rahmat, 2013; Feintrenie et al., 2010; Rist et al., 2010), and analysed the determinants of smallholder yields and income variations (Lee et al., 2014). Due to a lack of data, however, the authors of the latter study were not able to quantify the effect of fertiliser application rates, which is an important constraint for smallholder production (Corley and Tinker, 2003). Earlier studies have performed a financial cost-benefit analysis based on primary data from 3 villages in 
Kalimantan (Belcher et al., 2004) and have analysed the level of technical efficiency of smallholder oil palm farmers in a supported production scheme in West Sumatra (Hasnah and Coelli, 2004). To the best of our knowledge no study has yet quantified smallholder yield gaps and identified the determinants of the observed gaps. Based on crop modelling and household survey data from Jambi Province, Indonesia, this chapter specifically aims at: (i) quantifying smallholder yield gaps relative to simulated potential and exploitable yields; (ii) identifying the major agronomic and institutional constraints in smallholder oil palm production. The intensification of oil palm production can help to improve the livelihoods of small scale farmers and to reduce the conversion of forest and peat lands into oil palm plantations. It is therefore essential to gain a deeper understanding of smallholder production potentials, existing yield gaps and production constraints.

\subsection{Material AND MEthodS}

\subsubsection{STUDY AREA}

The study was carried out in Jambi province, Sumatra. For the years 2010-12, the mean annual temperature was recorded at $27.0^{\circ} \mathrm{C}$ with mean annual precipitation of $2403 \mathrm{~mm}$ (BMKDG, 2014). Jambi is inhabited by around 3.26 million people with agriculture employing the main share of the working population. After rubber, oil palm is the second most important crop in the province. In 2011, oil palm was cultivated on approximately 532 thousand hectares (DPK, 2011). While around 154 thousand hectares were managed by private and 19 thousand hectares by government estates, 359 thousand hectares were operated by smallholder farmers (DPK, 2011).

The group of small scale farmers can be classified into supported and independent smallholders, depending on the mode of engagement into the oil palm sector (Vermeulen and Goad, 2006; Zen et al., 2006). While supported smallholders typically engage in a contract with a private sector or government led company, independent smallholders operate without any form of support or assistance. In Indonesia, the first oil palm smallholders were linked to estates in the framework of so 
called nucleus estate smallholder schemes (NES). In such schemes a large scale plantation ('nucleus') is surrounded by oil palm smallholdings ('plasma'). Typically smallholders receive on a loan basis technical and financial assistance with the establishment and management of their parcels, including agronomic extension services, input provision and subsidies, as well as marketing support (Rist et al., 2010; McCarthy and Cramb, 2009; Vermeulen and Goad, 2006; Zen et al., 2006). The loan is repaid through subtracting a certain amount from the smallholders' factory processing returns. Once the debt is cleared smallholders obtain land titles for their oil palm parcels (Zen et al., 2006). With a decrease of political support after the end of the New Order regime, independent smallholders gained in importance (Zen et al., 2006). In 2011, around 98 thousand supported (or formerly supported) smallholders managed around 196 thousand hectares of oil palm plantations, while 83 thousand independent farmers cultivated 163 thousand hectares (DPK, 2011).

\subsubsection{FARM SURVEY}

Within Jambi province, data was collected in five regencies (Sarolangun, Batanghari, Muaro Jambi, Bungo, and Tebo), which were chosen purposely in order to represent the major share of smallholder oil palm producers in lowland Jambi province. In order to capture geographical disparity and regional diversity, we randomly selected 4 districts per regency and 2 villages per district (Faust et al., 2013). The study further includes 5 purposively selected villages, which are located near the protected areas 'Bukit Duabelas' national park and 'Harapan' rain forest. Within these villages and under the roof of a 'Collaborative Research Centre' additional research activities are carried out by a range of scientific projects (Faust et al., 2013).

As villages were found to differ significantly with respect to population size, randomly selected villages were divided into 4 quarters. Accordingly, 6 households were selected randomly from each of the 10 villages in the lowest quartile, 12 household per village from the second quartile, 18 household per village from the third and 24 per village from the largest quartile. Additionally, about 20 households were selected from each of the 5 purposively selected villages, including a number of purposively selected 
households which manage oil palm and rubber plantations where supporting research activities are carried out.

Thus, our survey includes 701 farm households, out of which 250 cultivate oil palm. As we are interested in quantifying smallholder yield gaps and determining their underlying causes, 14 farmers that are not managing their oil palm parcels and thus could not give detailed input-output information were excluded from the analysis. Our final analysis is hence based on farm level data of 236 oil palm farmers, as well as production data from 363 oil palm plots. More precisely, our sample contains 170 independent smallholder households cultivating 241 oil palm plots and 66 supported smallholder households with 122 plots. ${ }^{23}$ While the main share of supported farmers was associated with the government led trans-migration program, a minority consists of farmers of local origin who have engaged in contract farming with the private sector through farmer groups.

A structured questionnaire was developed and pre-tested during August and September 2012, in order to ensure consistency and accuracy of the data. The final questionnaire was introduced to a team of field assistants, which were carefully trained at the University of Jambi. The questionnaire included (1) detailed input-output data from all oil palm parcels cultivated by a given household; (2) institutional framework of farm activities; and (3) socio-economic household characteristics. Input-output details were collected for the 12 months period preceding the date of interview. Data collection took place between October and December 2012.

\subsubsection{YIELD POTENTIAL AND EXPLOITABLE YIELD}

Key information for yield gap analysis is the determination of potential yields in a given region. For annual crops this is widely done by detailed mechanistic crop models (van Ittersum et al., 2013). However, available soil and climate data are often, as in this study, not sufficient to run such models for tropical perennial crops. We therefore use a recently published simple physiological oil palm model called PALMSIM (Hoffmann et al.,

${ }^{23}$ The number of supported farmers slightly differs from Chapter 2 . This is due to the fact that 4 farmers have adopted oil palm independently and subsequently joined supported schemes. 
2014). PALMSIM simulates potential oil palm growth and yield on a monthly time step for the typical commercial life time of 25-30 years. In PALMSIM yield levels are only limited by incoming solar radiation. PALMSIM was evaluated against a range of sites in Southeast Asia and it shows indeed a match with yields from highest fertiliser trials (Hoffmann et al., 2014). Necessary input data, i.e. monthly solar radiation, was derived using the MarkSim weather generator. Based on observed data from the WORLDCLIM data base, MarkSim stochastically generates a range of possible annual weather scenarios for a given region (Jones and Thornton, 2013). In order to derive the potential yield $\left(Y_{p}\right)$ for Jambi province, we generated weather scenarios for 99 years and ran PALMSIM with each of it.

It is debatable, in how far yield potentials are exploitable under practical conditions. Generally, the exploitable yield is considered to be around $75-80 \%$ of the yield potential, which can be attributed to limitations in resource use efficiency and cost effectiveness (van Ittersum et al., 2013). In fact, yields that were recorded in a field trial in east Sumatra (Riau province), which was part of the PALMSIM evaluation data set (Hoffmann et al., 2014), reach around $85 \%$ of the yield potential as modeled by PALMSIM under a high fertilization regime (planting density of 143 plants/ha on a flat terrain with palms receiving $1.75 \mathrm{~kg} \mathrm{~N} /$ palm, $0.8 \mathrm{~kg}$ P/palm, $2.2 \mathrm{~kg} \mathrm{~K} /$ palm, $1.5 \mathrm{~kg}$ $\mathrm{Mg} /$ palm and $0.05 \mathrm{~kg} \mathrm{~B} /$ palm). Due to the proximity and similarity in agro-ecological conditions of Riau and Jambi province (solar radiation around 5800-6300 Mj/m²/year, high rainfall $>2000 \mathrm{~mm} /$ year) observed yields are likely to be attainable in the given area of research. We therefore assess smallholder performance against the exploitable yield, which is set as $80 \%$ of the yield potential obtained from PALMSIM.

\subsubsection{DETERMINANTS OF YIELD GAPS}

In order to analyze smallholder production constraints we estimate a yield gap model using ordinary least squares. The model includes all plots that are in the physiological stage of production (i.e. all plots that are 3 years and older). Formally, we estimate the following model: 


$$
\operatorname{Ygap}_{i}=\beta_{0}+\beta_{J} X_{i}+\beta_{k} X_{i}^{2}+\beta_{l} \text { Xpage }_{i} \text { fert }_{i}+\beta_{m} H_{i}+\varepsilon_{i}
$$

$Y_{g a p}$ is defined as the exploitable yield gap, which is defined as the difference between the exploitable yield and the recalled yield on plot $i . X_{i}$ is a vector of plot and plot management characteristics including the farm level oil palm area, the age of the plantation, the quantity of applied fertilizers, the quantity of applied herbicides, and the harvesting frequency. In perennial crops, yield levels (and yield gaps) are partly determined by an age specific, plant physiological pattern. We therefore introduce an interaction term to capture structural changes of a given explanatory variable over time. More concrete, $\operatorname{Xpage}_{i} X \mathrm{fert}_{i}$ indicates the interaction between plantation age and fertilizer use. The vector $H_{i}$ includes a set of household characteristics such as the age of the household head, the level of education of the household head, whether or not the farmer has been engaged in oil palm cultivation as supported farmer, a set of regency dummies to reflect regional diversity, and the mode the household was selected into the sample. $\varepsilon_{i}$ is the error term assumed to be normally distributed with mean 0 and variance $\sigma^{2}$. A detailed description and summary statistics of all variables included in the model is given in Table 4.1.

Table 4.1. Definitions and descriptive statistics for variables used in the yield gap model.

\begin{tabular}{|c|c|c|}
\hline Variable & Definition (unit of measurement) & $\begin{array}{c}\text { Mean } \\
\text { (Std. Dev.) }\end{array}$ \\
\hline Yield gap & $\begin{array}{l}\text { Difference between the exploitable yield and } \\
\text { the attained yield on plot i (kg FFB/ha) }\end{array}$ & $\begin{array}{l}11029.6 \\
(9053.4)\end{array}$ \\
\hline Oil palm area & Farm level area under oil palm (ha) & $\begin{array}{l}6.4 \\
(9.9)\end{array}$ \\
\hline Plantation age & Age of the oil palm plantation (years after planting) & $\begin{array}{l}10.6 \\
(6.1)\end{array}$ \\
\hline Fertilizer use & Quantity of fertilizers applied per plot (kg/ha) & $\begin{array}{c}414.6 \\
(381.3)\end{array}$ \\
\hline Herbicide use & Quantity of herbicides applied per plot (liter/ha) & $\begin{array}{l}5.6 \\
(5.4)\end{array}$ \\
\hline 30 day harvesting cycle & $\begin{array}{l}\text { Dummy variable indicating a } 30 \text { day cycle between } \\
\text { FFB harvests (omitted from the model) }\end{array}$ & 0.1 \\
\hline 15 day harvesting cycle & $\begin{array}{l}\text { Dummy variable indicating a } 15 \text { day cycle between } \\
\text { FFB harvests }\end{array}$ & 0.7 \\
\hline
\end{tabular}




\begin{tabular}{|c|c|c|}
\hline Variable & Definition (unit of measurement) & $\begin{array}{c}\text { Mean } \\
\text { (Std. Dev.) }\end{array}$ \\
\hline 10 day harvesting cycle & $\begin{array}{l}\text { Dummy variable indicating a } 10 \text { day cycle between } \\
\text { FFB harvests }\end{array}$ & 0.1 \\
\hline $\begin{array}{l}\text { Plantation age* } \\
\text { fertilizer use }\end{array}$ & $\begin{array}{l}\text { Interaction term between plantation age and } \\
\text { fertilizer use }\end{array}$ & $\begin{array}{c}5195.2 \\
(6738.6)\end{array}$ \\
\hline Age & Age of the household head (years) & $\begin{array}{c}46.9 \\
(11.8)\end{array}$ \\
\hline Education & $\begin{array}{l}\text { Education level of the household head } \\
\text { (years of schooling) }\end{array}$ & $\begin{array}{c}8.1 \\
(0.8)\end{array}$ \\
\hline Supported smallholder & $\begin{array}{l}\text { Dummy variable indicating whether the farmer } \\
\text { engaged in oil palm cultivation as supported } \\
\text { smallholder }\end{array}$ & 0.4 \\
\hline Muaro Jambi & $\begin{array}{l}\text { Dummy variable indicating whether the household } \\
\text { lives in Muaro Jambi regency (omitted from the } \\
\text { model) }\end{array}$ & 0.2 \\
\hline Sarolangun & $\begin{array}{l}\text { Dummy variable indicating whether the household } \\
\text { lives in Sarolangun regency }\end{array}$ & 0.3 \\
\hline Batanghari & $\begin{array}{l}\text { Dummy variable indicating whether the household } \\
\text { lives in Batanghari regency }\end{array}$ & 0.4 \\
\hline Tebo & $\begin{array}{l}\text { Dummy variable indicating whether the household } \\
\text { lives in Tebo regency }\end{array}$ & 0.1 \\
\hline Bungo & $\begin{array}{l}\text { Dummy variable indicating whether the household } \\
\text { lives in Bungo regency }\end{array}$ & 0.1 \\
\hline $\begin{array}{l}\text { Random } \\
\text { household }\end{array}$ & $\begin{array}{l}\text { Dummy variable indicating whether a household was } \\
\text { selected into the sample randomly }\end{array}$ & 0.9 \\
\hline $\begin{array}{l}\text { Random } \\
\text { village }\end{array}$ & $\begin{array}{l}\text { Dummy variable indicating whether a village was } \\
\text { selected into the sample randomly }\end{array}$ & 0.8 \\
\hline
\end{tabular}

\subsection{ResUltS AND DISCUSSION}

\subsubsection{QUANTIFYING YIELD GAPS}

In order to be able to quantify smallholder yield gaps, precise production information over the whole oil palm life cycle is needed. Accordingly, Figure 4.1 shows FFB yields as realized by smallholders over different plantation ages. Attained yields are plotted against potential and exploitable yields.

Potential yields average at 34.2 tons FFB/ha (average annual production between years 4-25 after plantation establishment), and peak at 40.4 tons FFB/ ha in year 10 after 
plantation establishment. Likewise, exploitable yields average at 27.3 tons FFB/ha and peak at 32.3 tons FFB/ha. Smallholder yields are well below both potential and exploitable yields. Smallholder farmers realize yield levels that average at $15.1 \pm 9.0$ tons FFB/ha (average annual production between years 4-25 after plantation establishment) and peak at $22.9 \pm 2.7$ tons FFB/ha in year 15 after plantation establishment. Yield gaps are especially large during the period of peak oil production (years 8-16 after plantation establishment), in which smallholders only manage to obtain around $50 \%$ of the exploitable yield.

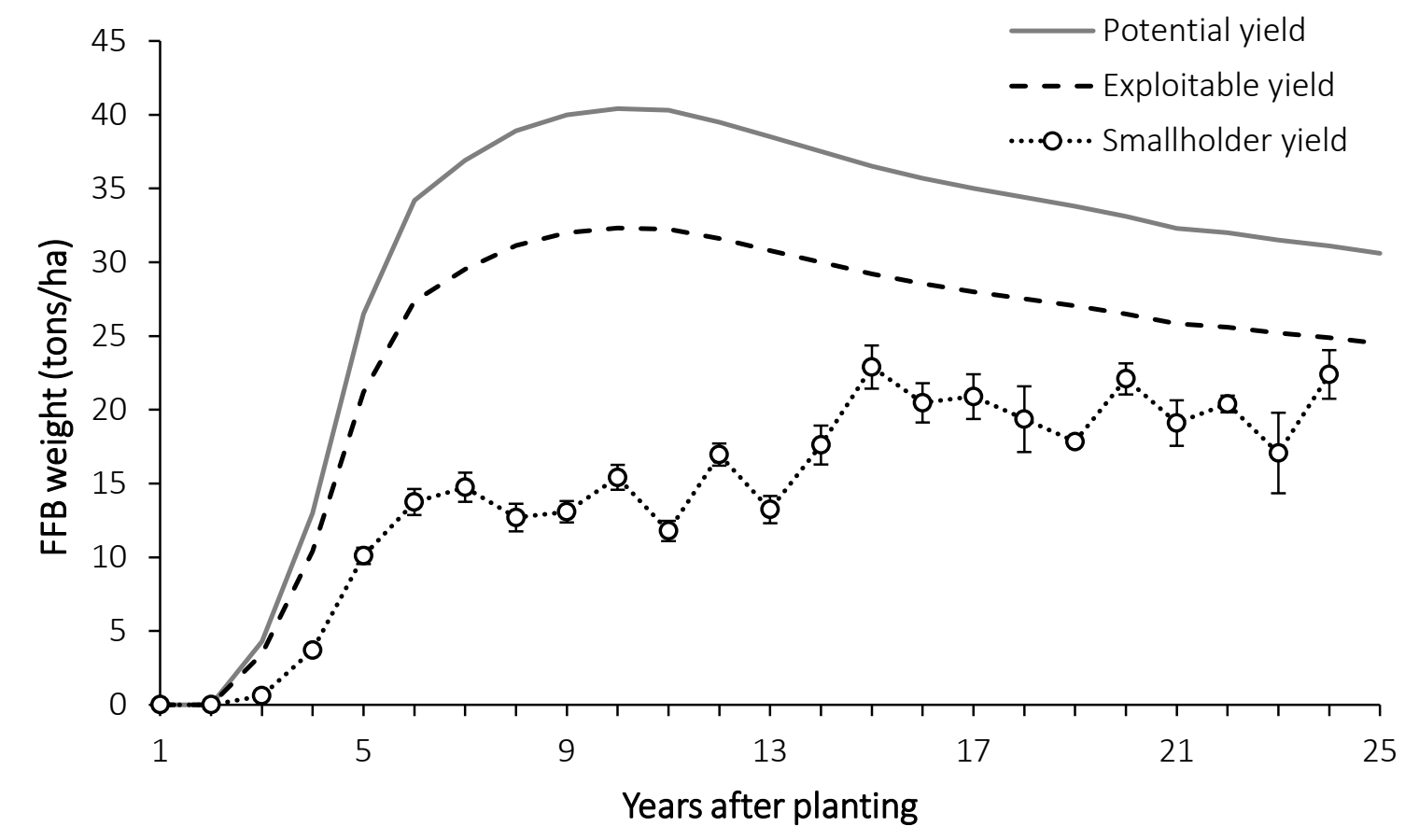

Figure 4.1. Potential, exploitable and smallholder FFB yields over a 25 year plantation life

cycle. Potential and exploitable yields are derived by PALMSIM. Smallholder yields include 363 oil palm plots cultivated by 236 farmers. Error bars indicate mean standard errors. Source: Household survey, 2012.

In general, the observed smallholder yields are in the range of yields as reported by other studies. Average smallholder yields are reported to be $15.4 \pm 7.5$ tons FFB/ ha in Sumatra (Lee et al., 2014); 15.9 tons FFB/ ha in Malaysia (Ismail et al., 2003); and 15 tons FFB/ ha in managed smallholder schemes in Malaysia (Cramb and Ferrano, 2010). As agro-ecological conditions and hence potential and exploitable yields are comparable 
across all studies, it is not unlikely that smallholder yield gaps have a similar magnitude in other oil palm growing regions in Indonesia and Malaysia.

In a next step, we quantify the yield gaps of smallholder oil palm plantations over a 20 year plantation life cycle by deducting their cumulative yields from the exploitable yield (Figure 4.2). As it has been shown that the status of smallholder support is an important factor in explaining smallholder yield variations (World Bank, 2011; Vermeulen and Goad, 2006; Hartemik, 2005; Corley and Tinker, 2003) we also show yield gaps for independent and supported farmers.

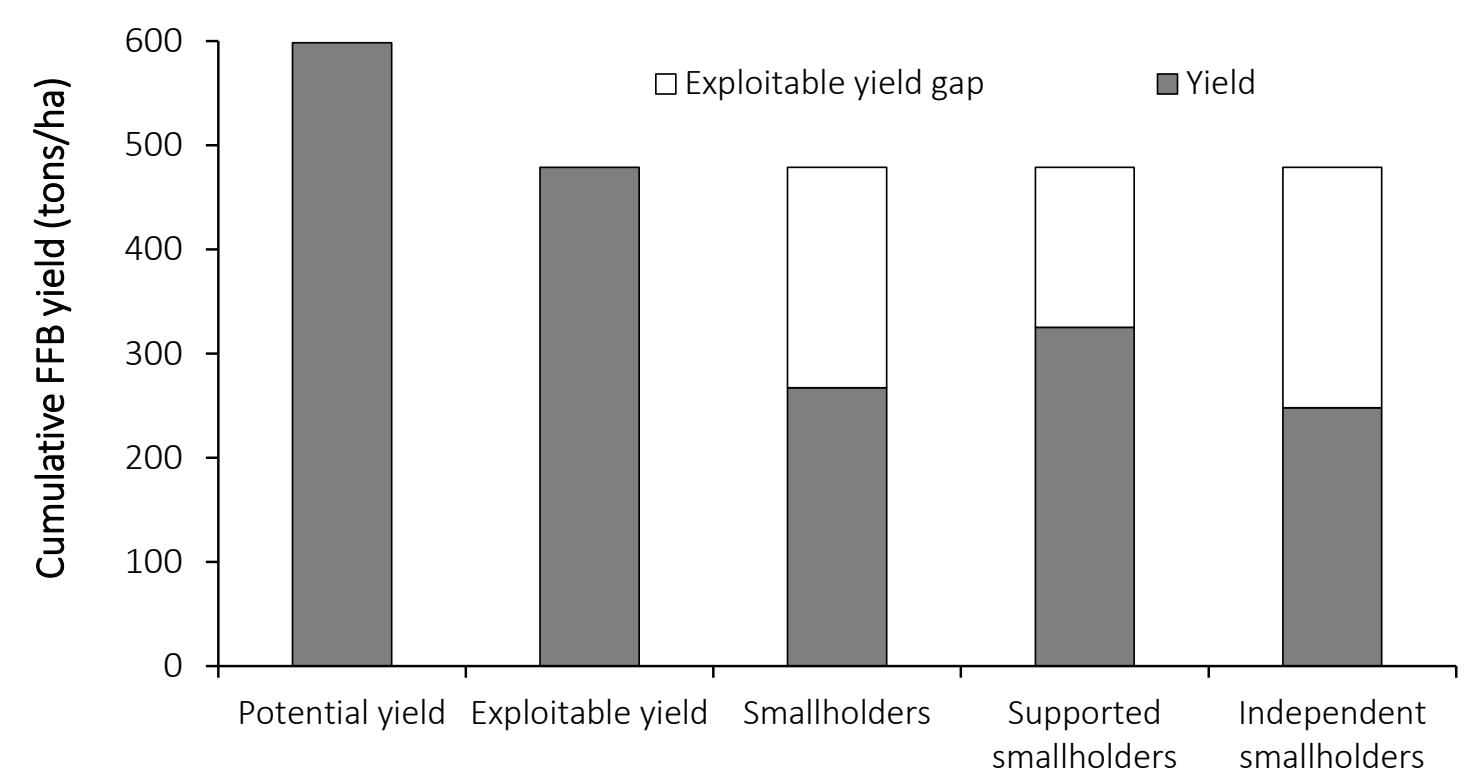

Figure 4.2. Cumulative potential, exploitable and smallholder yields along with exploitable yield gaps of smallholder farmers over a 20 year plantation life cycle. The cumulative potential yield is the sum of annual potential yields as derived by PALMSIM. The cumulative exploitable yield is set as $80 \%$ of the cumulative potential yield. The cumulative smallholder yield is the sum of average annual smallholder yields for different plantation ages (1-20 years after planting). Source: Household survey, 2012.

Over a 20 year plantation life cycle, the potential yield for Jambi province cumulates to 600 tons FFB/ha and the exploitable yield to 480 tons FFB/ha. Smallholders are able to attain cumulative yields that are 212 tons FFB/ha below the exploitable yield corresponding to only $56 \%$ of the exploitable yield. The exploitable yield gap for supported smallholders cumulates to 153 tons FFB/ha, which corresponds to around 
$68 \%$ of the exploitable yield. Independent smallholders achieve yields that are on average 230 tons FFB/ha below the exploitable yield, thereby obtaining only $52 \%$ of the exploitable yield.

Combining the average annual yield gap (cumulative exploitable yield gap / 20 year plantation life cycle) for independent (11.5 tons FFB/ha) and supported (7.7 tons FFB/ha) farmers with the area under smallholder oil palm plantations (DPK, 2011) we can try to quantify annual yield losses for Jambi province. Assuming an oil extraction rate of 20\% (Corley and Tinker, 2003), around 677 thousand tons of CPO were lost in 2011 due to production constraints. This is equivalent to $47 \%$ of the total CPO production of Jambi province in 2011, which reached 1.4 million tons CPO (BPS, 2012). Such figures are only a rough estimation, as they assume normally distributed yield gaps and plantation ages among oil palm smallholdings. However, they underline the magnitude and economic implications of smallholder yield gaps.

\subsubsection{DETERMINANTS OF SMALLHOLDER YIELD GAPS}

To identify the factors determining the observed yield gaps, we estimate a yield gap model as described in equation (4.1) using ordinary least squares. Table 4.2 gives the estimated coefficients along with standard errors. As the dependent variable is the exploitable yield gap, defined as the difference between the exploitable and observed yield, a negative coefficient indicates that an increase in the respective independent variable will lead to a reduction in the yield gap. A positive coefficient, in turn, amplifies the observed yield gap.

Our results indicate that plantation age is highly significant in determining smallholder yield gaps. These results are in line with smallholder yield curves as presented in Figure 4.1. According to our model, smallholder yield gaps grow continuously up to year 14, where the maximum gap is reached (around 18.1 tons FFB/ha). They decline thereafter, but they never become negative over the 25 year plantation life cycle. In year 25 the estimated yield gap is still at about 5.4 tons FFB/ha. Thus, yield gaps are largest during the phase of initial yield increase (years 3-7) and peak 
oil production (years 8-16). One possible explanation is the use of inferior planting material as well as management deficiencies during the immature phase of plantation development by smallholder farmers. Both can have a negative feedback on fruit onset and yields during the early phase of production (Corley and Tinker, 2003).

We further find a significant effect of the total oil palm area of a given farm on plot level yield gaps. The yield gap decreases with each additional hectare under oil palm up to around 20 ha. Thereafter, the yield gap is observed to increase with a further increase in oil palm plantation size. This result suggests that medium sized farms have a comparative advantage over small and large farms.

With respect to the included management variables, we find fertilization and harvesting frequencies to have a significant effect on yield gaps. Accordingly, the application of fertilizers reduces the yield gap from the very first unit and at an increasing rate with the application of subsequent units. The interaction term between fertilizer application and plantation age suggests that the negative fertilization effect on yield gaps becomes stronger as plantations mature. Overall, these results suggest that fertilizers are underused, which could be due to limited access to input markets. A case study from Bungo also finds that the dosage and application of fertilizers are crucial in determining FFB yields (Feintrenie et al., 2010).

Shortening the harvesting cycle to 10 days between FFB harvests is found to reduce yield gaps by around 4.1 tons FFB/ha when compared to a harvesting cycle of 30 days. Other studies also find smallholders harvesting once a month to have the lowest yield levels when compared to smallholders with shorter harvesting intervals (Lee et al., 2014; Feintrenie et al., 2010), and find a positive effect of harvesting intervals on yields on commercial estates (Donough et al., 2009). Harvesting frequencies are in fact a measure of minimizing FFB loss, rather than increasing FFB yields. A low number of harvests, and thus long harvesting cycles, potentially reflect a growing amount of overripe FFB which decay on the ground, as they are not harvested on time (Corley and Tinker, 2003). We do not find a significant effect of herbicide applications on yield gaps. 
Table 4.2. Determinants of yield gaps.

\begin{tabular}{|c|c|}
\hline Explanatory variable & Coefficient (Std. Err.) \\
\hline \multicolumn{2}{|l|}{ Plantation characteristics } \\
\hline Plantation age (years) & $2794.0^{* * *}(299.6)$ \\
\hline Square term & $-99.8^{* * *}(11.8)$ \\
\hline Oil palm area (ha) & $-472.5^{* * *}(157.8)$ \\
\hline Square term & $11.7^{* * *}(3.2)$ \\
\hline \multicolumn{2}{|l|}{ Management characteristics } \\
\hline Fertilizer use (kg/ha) & $-2.6^{* * *}(3.5)$ \\
\hline Square term & $-3 \mathrm{E}-03^{* * *}(3 \mathrm{E}-03)$ \\
\hline Plantation age* fertilizer use & $-0.1^{* * *}(0.2)$ \\
\hline Herbicide use (liter/ha) & $427.1(235.3)$ \\
\hline Square term & $-25.8(12.4)$ \\
\hline 15 day harvest cycle (dummy) & $-183.5(1521.0)$ \\
\hline 10 day harvest cycle (dummy) & $-4151.2^{* * *}(1947.6)$ \\
\hline \multicolumn{2}{|l|}{ Household characteristics } \\
\hline Age (years) & $14.5(41.2)$ \\
\hline Education (years of schooling) & $63.3(129.2)$ \\
\hline Supported smallholder(dummy) & $-2402.5^{* *}(1223.2)$ \\
\hline Sarolangun (dummy) & $3287.3^{* *}(1414.9)$ \\
\hline Batanghari (dummy) & $1111.0(1270.0)$ \\
\hline Tebo (dummy) & $-1497.5(2281.2)$ \\
\hline Bungo (dummy) & $988.6(2163.6)$ \\
\hline Random village (dummy) & $1980.0(1626.1)$ \\
\hline Random household (dummy) & $-2621.4(1894.1)$ \\
\hline Constant & $-695.9(3816.8)$ \\
\hline No. of observations & 317 \\
\hline Adj. $R^{2}$ & 0.35 \\
\hline $\mathrm{F}$ & 9.57 \\
\hline \multicolumn{2}{|c|}{$\begin{array}{l}\text { Notes: }{ }^{* * *},{ }^{* *} \text { indicates } 1 \% \text { and } 5 \% \text { level of significance, respectively. The dependent variable is t } \\
\text { yield gap between the exploitable and observed yield (kg FFB/ha). Coefficient estimates are } \\
\text { shown with standard errors in parentheses. The reference harvesting cycle is } 30 \text { days between } \\
\text { harvests. The reference regency is Muaro Jambi. }\end{array}$} \\
\hline
\end{tabular}

With respect to household characteristics, we do not find age or education levels of the household head to have a significant effect on yield gaps. Although we control for a set of plot management characteristics, the coefficient for the supported farmer dummy indicates that supported oil palm producers have a lower yield gap than independent farmers. Having received support reduces the yield gap by around 2.4 tons 
FFB/ha. Such differences are likely to be caused by technical support and agricultural extension services offered by the contract partner, which are not directly included in our model. More concrete, through the connection to private sector companies, supported smallholders might have better access to high quality planting material and acquire management skills through technical assistance in the agronomic management of their oil palm stands (Vermeulen and Goad, 2006). Even though we recorded data on the name of the planted cultivar, a large share of farmers could not recall the type, or in case the plantation was not self-established, did not have information on it, so we are not able to disentangle the respective effects.

Regency dummies are assessed against Muaro Jambi regency. We find households residing in Sarolangun to have significantly larger yield gaps compared to households in Muaro Jambi. Other regency dummies, as well as dummies controlling for the mode of household selection into the sample, do not significantly influence yield gaps.

\subsubsection{CHARACTERISTICS OF SUPPORTED AND INDEPENDENT OIL PALM FARMERS}

The results of the econometric model suggest that supported oil palm farmers have a lower yield gap than independent smallholders. In this section we will hence describe differences between these two groups of farmers with respect to farm attributes, plot and management characteristics, economic performance, and marketing.

Concerning farm characteristics, supported smallholders have significantly smaller oil palm plantations and cultivate less rubber (Table 4.3). Looking at plot level and management characteristics, we find that supported smallholders have started oil palm cultivation earlier than independent farmers, as their plots are on average more mature. Supported farmers further apply significantly more fertilizer, invest more labor, use less herbicides and have significantly shorter harvesting intervals (although the difference is quite small in absolute terms) when compared to independent farmers. While independent smallholders realize average yields of $12.2 \pm 8.8$ tons FFB/ha, 
supported smallholders obtain $19.5 \pm 7.3$ tons FFB/ha (Table 4.3). Thus, we find a yield difference of 6.4 tons FFB/ha between independent and supported famers. Yield differences of around 3.6 tons/ha, with independent smallholders achieving 14.2 tons FFB/ha and supported farmers achieving 17.8 tons FFB/ha have been reported previously (Lee et al., 2014). Our data also confirms the presence of a large variation of yields across smallholder farms. Such variation has also been observed by previous studies (Lee et al., 2014; Vermeulen and Goad, 2006). However, only the latter study quantifies these variations and finds similar results, indicating that oil palm production is relatively heterogeneous within the smallholder sector.

Table 4.3. Farm, plot, and management characteristics of independent and supported smallholders.

\begin{tabular}{|c|c|c|c|c|c|c|}
\hline \multirow[b]{2}{*}{ Variable } & \multicolumn{3}{|c|}{ Independent smallholders } & \multicolumn{3}{|c|}{ Supported smallholders } \\
\hline & $\begin{array}{c}\text { Mean } \\
\text { (Std. Dev.) }\end{array}$ & Min. & Max. & $\begin{array}{c}\text { Mean } \\
\text { (Std. Dev.) }\end{array}$ & Min. & Max. \\
\hline \multicolumn{7}{|l|}{ Farm characteristics ${ }^{a}$} \\
\hline Farm size (ha) & $7.5(12.3)$ & 0.3 & 86 & $4.3(2.9)$ & 1 & 19 \\
\hline Oil palm area (ha) & $3.8(6.9)$ & 0.1 & 51 & $3.3^{* * *}(2.6)$ & 0.8 & 19 \\
\hline Rubber area (ha) & $3.7(7.1)$ & 0 & 60 & $1.0^{* * *}(1.6)$ & 0 & 7.5 \\
\hline \multicolumn{7}{|l|}{$\begin{array}{l}\text { Plot and management } \\
\text { characteristics }^{\mathrm{b}}\end{array}$} \\
\hline Plantation age (years) & $6.9(4.8)$ & 0 & 20 & $14.5^{* * *}(6.6)$ & 0 & 31 \\
\hline Fertilizer use (kg/ha) & $306.5(334.8)$ & 0 & 1500 & $527.3^{* * *}(404.3)$ & 0 & 1800 \\
\hline Herbicide use (liter/ha) & $5.9(5.6)$ & 0 & 30 & $4.8^{* * *}(5.2)$ & 0 & 22.5 \\
\hline Labor use (days/ha) & $21.6(20.3)$ & 0 & 162.8 & $30.4^{* * *}(19.0)$ & 0 & 116.5 \\
\hline $\begin{array}{l}\text { No. of harvests } \\
\text { (no./month) }\end{array}$ & $2.1(0.3)$ & 1 & 3 & $2.2^{* * *}(0.4)$ & 1 & 3 \\
\hline Yield (tons FFB/ha) & $12.2(8.8)$ & 0.1 & 39.2 & $19.5^{* * *}(7.3)$ & 1.2 & 37.0 \\
\hline
\end{tabular}

These differences in yields and management practices are also mirrored in smallholders' economic performance. Table 4.4 compares mean values of revenues, input costs and gross margins between independent and supported smallholders for oil palm plantations. Revenues refer to the output multiplied by output price; input costs include all external inputs purchased by the farmer (excluding labor costs); labor costs 
include costs for all hired labor; sharecropping costs include all costs that arise from share-cropping arrangements between the farmer and a share-cropper (typically the share-cropper receives a certain yield share); gross margins are defined as revenues less input, labor, and sharecropping costs.

We find supported smallholders to achieve significantly higher revenues due to higher yields but also higher output prices. They receive on average almost $21 \%$ higher prices than independent smallholders. We also find gross margins to be significantly larger for supported farmers, although they have considerably higher expenses for external inputs and hired labor. Previous gross margin comparisons between independent and supported smallholders confirm these findings (Lee et al., 2014).

Table 4.4. Revenues, costs and gross margins of oil palm production for independent and supported smallholders.

\begin{tabular}{lcc}
\hline & $\begin{array}{c}\text { Independent smallholders } \\
(\mathrm{n}=241)\end{array}$ & $\begin{array}{c}\text { Supported smallholders } \\
(\mathrm{n}=122)\end{array}$ \\
\hline Revenues (000 IDR/ha) & $6986.4^{* * *}(8764.5)$ & $17903.3(10040.5)$ \\
Input costs (000 IDR/ha) & $1826.8^{* * *}(1802.3)$ & $2731.9(2055.8)$ \\
Labor costs (000 IDR/ha) & $806.1^{* * *}(1226.7)$ & $1832.3(2153.4)$ \\
Sharecropping costs (000 IDR/ha) & $188.0(1325.8)$ & $90.8(689.9)$ \\
Gross Margin (000 IDR/ha) & $4165.5^{* * *}(7433.5)$ & $13248.4(9053.4)$ \\
Average price received (IDR/kg FFB) & $796^{* * *}(252)$ & $963(224)$ \\
\hline
\end{tabular}

Notes: Mean values are shown with standard deviation in parenthesis. ${ }^{* * *}$ indicates differences are significant at the $1 \%$ level.

The difference in gross margins between independent and supported smallholders is particularly large during the phase of initial yield increases in the years 47 (Figure 4.3). The difference gets smaller with increasing age of oil palms, which might indicate a learning effect among the independent producers. We do not find a significant difference during the early phase of the plantation life cycle, including plantation establishment and management of the immature stand. 


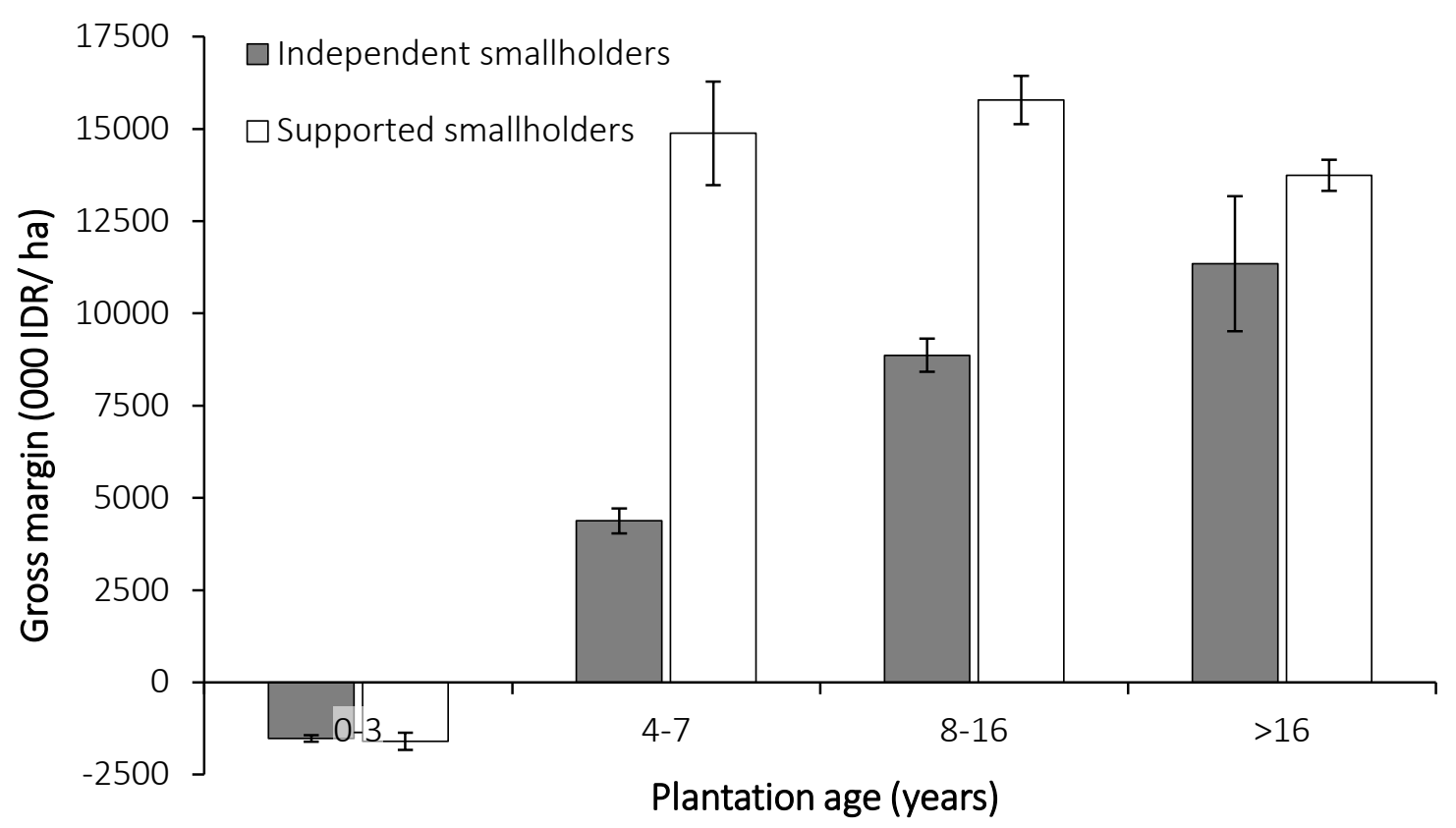

Figure 4.3. Gross margins of supported and independent smallholders over different plantation ages. Gross margins are calculated as annual revenues (output multiplied by output price) less input, labor and sharecropping costs. Error bars indicate standard errors. Source: Household survey, 2012.

In order to better understand the reasons for observed price differences, Table 4.5 gives further insights on output marketing channels for independent and supported smallholders. In general, processing mills play a crucial role in the oil palm sector, as fatty acids start to decay 48 hours after harvesting of fresh fruit bunches, leading to a decline in oil quality (Corley and Tinker, 2003). As the production quantity of independent smallholders is limited, they are typically not able to sell directly to the processors and hence sell their produce primarily to traders. Private sector companies and farmer groups only play a minor role. Moreover, processing mills are often located relatively far away from the oil palm plots and most smallholders do not have the means to transport their produce to the mill. Traders often pick up the FFB directly from the plot and deliver it to the processing mill. Independent smallholders hence often depend on middlemen to secure their access to the mills (Feintrenie et al., 2010). 
Table 4.5. Output marketing details for independent and supported smallholders.

\begin{tabular}{|c|c|c|}
\hline Variable & $\begin{array}{l}\text { Independent smallholders } \\
\qquad(\mathrm{n}=113)\end{array}$ & $\begin{array}{l}\text { Supported smallholders } \\
\qquad(n=63)\end{array}$ \\
\hline \multicolumn{3}{|l|}{ Share of farmers (\%) selling to } \\
\hline Traders & 81 & 17 \\
\hline Farmer groups & 8 & 50 \\
\hline Processing mills & 14 & 41 \\
\hline
\end{tabular}

Notes: Differences are significant at the $1 \%$ level.

Supported farmers in contrast, either operate in village level famer groups, or -by contract design- are able to deliver their output to the mill of their contract partner. As a result, supported farmers are mainly selling to farmer groups and private sector companies. Apparently, supported smallholders are able to avoid middlemen (traders) and hence receive significantly higher prices as compared to independent farmers.

\subsection{CONCLUSION}

Driven by the increasing demand for vegetable oils and biofuels, the area under oil palm has almost tripled during the last two decades. In the major producing countries, Indonesia and Malaysia, recent oil palm expansion has been associated with deforestation and environmental degradation. In order to minimize the ecological impacts and to enhance the social benefits of this expansion process, there is an urgent need to increase palm oil yields on existing plantations. Despite smallholders' growing importance in the oil palm sector, they have received relatively little attention in recent research. Based on crop modelling analysis and household survey data, in this chapter we have established potential and exploitable yield levels for Jambi province, and quantified smallholder yield gaps and identified their major production constraints.

We find that oil palm smallholdings offer a tremendous potential for future yield increases, since they obtain only $56 \%$ of cumulative exploitable yields over a 20 year plantation life cycle. As supported smallholders achieve higher yields, the package of technical assistance offered by their contract partner has apparently increased their management skills. Nonetheless, important determinants of smallholder yield gaps are 
low fertilizer use and harvesting cycles, which go beyond optimal levels. These results suggest that smallholders are constrained by limited knowledge about best management practices and by imperfect access to input markets. Policy makers should focus on the removal of such constraints by improving the public agricultural extension service and the availability of fertilizers through, for example, reducing transaction costs. Such measures should primarily focus on independent farmers as they show larger deficits in plantation management and offer a greater potential for yield increases.

Beyond agronomic limitations, we find evidence that especially independent smallholders do not have direct access to the processing industry, but are dependent on middlemen and thus receive lower FFB prices. Investments in infrastructure, the promotion of small- to medium-sized processing mills, and the promotion of smallholder marketing cooperatives are potential policy measures to improve smallholders' access to the processing industry. Overall, increasing smallholder yields has the potential to improve the livelihoods of smallholders and foster the economic development of rural communities, thereby strengthening the oil palm sector as a whole.

While the potential economic gains of yield increases on oil palm smallholdings are substantial, the net ecological outcomes are hard to predict. In principle, higher yields imply that the same amount of palm oil could be produced on less land reducing the pressure on forest resources. Higher returns, however, also improve the profitability of oil palm cultivation against other land uses including forests. Using a global computable general equilibrium model, a recent study shows that an increase in oil palm yields in Indonesia and Malaysia leads to an expansion of oil palm acreage and to a slight decrease in forest area in the two countries due to a relocation of fatty oil production from temperate to tropical regions (Villoria et al., 2013). Thereafter, it is essential that policy measures addressing yield intensifications at the farm level also entail environmental safeguards on the regional and national level. 


\section{CHAPTER 5: CONCLUSION}

\subsection{SYNOPSIS}

Agriculture sustains the nutritional demand for over 7 billion people and is the most important source of livelihoods for rural populations across the globe. It plays a key role in the reduction of poverty and the eradication of hunger. At the same time, agricultural production relies on an increasing share of the world's ecological resources and is often associated with negative environmental externalities and the depletion of ecosystems. The growing world population, in conjunction with changes in dietary habits, will further add pressure on the global resource base. A more frequent consumption of resource intensive, high value food products such as animal protein and vegetable oils is expected to become the major driver behind land requirements for food in the near future. In order to sustain future demand increases, cropland expansion is likely to occur at the frontier of the remaining forests of tropical countries. These projected changes are expected to have dramatic impacts on the diversity of ecosystems around the world and on their ability to provide vital ecosystem services that are necessary to sustain the production of agricultural commodities and rural livelihoods of smallholder farmers. As small-scale farms are especially vulnerable to the depletion of agricultural ecosystems, the human dimension of agricultural induced land use changes deserves special attention from scholars and policy makers.

A typical case of such a transformation is the expansion of oil palm, for which large areas of tropical forests are converted into agricultural plantations. Over the past 100 years, oil palm has come from being a subsistence crop of West and Central Africa to the world's most produced and traded vegetable oil. Since 1990, the global area under oil palm plantations has almost tripled, while the production of CPO has more than quadrupled. Especially during its initial diffusion, oil palm was perceived as a social, environmental and economic panacea, which could offer rural development 
opportunities to producer countries while supplying the global economy with a renewable and carbon neutral source of energy.

However, it was shown later that the expansion of oil palm also entails considerable environmental and socio-economic threats. The major ecological drawbacks are deforestation and the loss of ecosystem services. Socio-economic threats entail an increasing vulnerability and economic marginalization of the rural population, conflicts over land use and land ownership between private sector companies and local communities, as well as negative implications for food availability and food security. In addition, oil palm smallholders face a set of agronomic and institutional constraints that hinder the achievement of the crop's full production potential.

While the early expansion of oil palm was mainly driven by large scale private sector plantations, the more recent expansion of oil palm is largely driven by smallholder farmers. Despite the growing economic relevance of the smallholder oil palm production sector, there is little empirical evidence on the drivers and implications of smallholder land use changes towards oil palm. The sustainable development of oil palm agriculture implies minimizing the associated environmental externalities, while maximizing its socio-economic benefits. In order to design adequate policies, it is of paramount importance to acquire knowledge on oil palm's diffusion process, its welfare implications, as well as persisting agronomic limitations in a smallholder context. The present study has contributed to the existing literature by empirically analyzing smallholder oil palm cultivation in Jambi province, Sumatra with regard to these aspects.

The key findings of the dissertation are the following.

The recent oil palm growth in smallholder agriculture in Jambi province is mainly related to independently operating farmers. Independent oil palm adoption is found to happen fastest in regions where the oil palm industry developed early on and where supported out-grower schemes have long been in place. The access to processing facilities is a crucial precondition for smallholder oil palm adoption. Through the establishment and support of large-scale plantations, processing facilities, and smallholder out-grower schemes, government policies have shaped the development of 
the oil palm agro-industry and indirectly contributed to a regional path-dependency of the diffusion of independent oil palm smallholdings.

The cultivation of oil palm is associated with increases in household consumption expenditure, calorie consumption and dietary quality. In particular, the expansion of oil palm does not seem to have negative impacts on food availability and food security in the study region. However, the observed effects can mainly be attributed to oil palm's higher returns to labor compared to rubber plantings and not to oil palm adoption per se. The labor-saving management of the crop in comparison to alternative land uses releases family labor resources and eases farm size expansion, and allows adopters to increase their off-farm income. The net livelihood outcome of oil palm adoption therefore depends on smallholder household attributes which define their access to factor markets. Variation in these attributes cause livelihood outcomes to be distributed unequally among adopters. The effects on household non-food expenditure are found to be significantly stronger at the upper tail of the distribution.

Existing oil palm smallholdings offer a great potential for future yield increases. Smallholder FFB yields show large variations and are generally far below plantation sector standards, especially independent smallholders are found to achieve significantly lower yields compared to (formerly) supported farmers. The package of technical assistance offered by their contract partner has apparently increased their management skills. The most important determinants of yield gaps are management practices such as fertilizer dosage and length of harvesting intervals. These results suggest that smallholders are constrained by limited knowledge about best management practices and by imperfect access to input markets.

\subsection{POLICY IMPLICATIONS}

Making the agricultural transformation towards oil palm more sustainable will require political action that tackles issues beyond existing private sector initiatives (e.g. the Roundtable on Sustainable Palm Oil). In general, these policies need to minimize the ecological threats while maximizing the economic benefits of the diffusion of oil palm in 
the smallholder sector. Against this background, the following policy implications can be derived from the present dissertation.

\subsubsection{ENVIRONMENTAL SUSTAINABILITY}

The environmental sustainability of oil palm expansion will mainly depend on the type of land use transformations that are associated with plantation establishment. By issuing concessions for plantation establishment and supporting out-grower schemes, the government has influence on the regional development of the oil palm industry. As the diffusion of independently managed oil palm smallholdings is found to be path dependent - with adoption being fastest in regions where plantation concessions, outgrower schemes and processing facilities were developed early on- the government also holds indirect control of the geographical expansion patterns of smallholder land use changes towards oil palm. In particular, reducing the ecological footprint of oil palm cultivation requires the government to demark land for (smallholder) plantation development that is already ecologically degraded and to secure that forest areas are spared from direct encroachment. This implies the development of a general land use plan, which separates land for agricultural operations from land for nature conservation. In order to effectively address undesired smallholder land use changes, land demarcation within the proximities of the palm oil agro-industry clusters should be prioritized. These policies should finally aim at a comprehensive issuing of land titles to smallholder farmers.

Another strategy to reduce the environmental externalities of palm oil production is to increase FFB yields on existing oil palm plantations. In theory, the demand for palm oil could be satisfied by using fewer cropland resources, which would reduce the pressure on remaining forests. As we find considerable yield gaps in oil palm smallholdings, measures to enhance FFB yields might indeed be a valid strategy to minimize the ecological impacts of oil palm expansion. However, higher returns to land would also improve the profitability of oil palm cultivation against other land uses, including forests, which might adversely affect the long-term tenability of conservation incentives. In addition, global land use patterns might shift as a result of increasing palm 
oil yields. Vegetable oil production could be reallocated from temperate to tropical regions. While land resources in northern countries could be spared, yield increases in oil palm might lead to the net expansion of oil palm plantations in tropical producer countries. In order to avoid these leakage effects, it is essential that policy measures addressing yield increases at the farm level also entail environmental safeguards on the regional and national level.

\subsubsection{SOCIO-ECONOMIC SUSTAINABILITY}

The socio-economic sustainability of oil palm cultivation will mainly be determined by its accessibility to smallholders, the disparities in associated livelihood benefits among adopters, the degree of regional specialization towards oil palm, and its implications on the economic vulnerability and nutritional adequacy of the rural population.

From a smallholder perspective, the accessibility of oil palm cultivation is largely

determined by the geographical distribution of the palm oil agro-industry; while the livelihood outcomes mainly depend on the scale of oil palm operations, the concrete agronomic management practices, and realized yield levels. As these factors are found to vary, the expansion of oil palm might foster regional disparities and social inequality among smallholder farmers.

Ensuring equal access to oil palm processors for all smallholder farmers in Jambi province would require considerable policy efforts. The state would either directly need to establish processing facilities in regions that are not connected to the oil palm industry, or it would need to grant concessions and provide incentives to private sector companies. However, it is questionable whether there are land resources that could be transformed with the consent of the local population and that would not cause significant ecological damage. Entering remote areas would potentially also require heavy investment in infrastructural development.

A more promising approach is to make the transition towards oil palm more sustainable and inclusive in terms of smallholder livelihoods in those regions where oil 
palm smallholdings are already in place. Within these regions, oil palm expansion might turn into a race for land, which may become a speculative object and a scare resource. Particularly more traditional land use practices, such rubber agro-forests, might gradually be replaced by the expansion of oil palm. Thus, farmers who depend on more traditional livelihoods and who are not able (or willing) to make the transition to more intensive forms of smallholder agriculture are potential losers of this transformation process as they lose the environmental resource base they depend on. Imprecisely defined land rights further complicate the scenario, easing illegal forest encorachment, distorting land markets and production processes. In order to make the transition more sustainable and inclusive, policy makers should focus on issuing land titles by explicitly accounting for traditional land use claims, inhibiting the development of speculative land markets, sparing certain land resources from plantation development, and improving access to agricultural investment capital for rural smallholders.

Another pathway of enhancing smallholder livelihood outcomes is to increase FFB yields on existing plantations. As yield levels are mainly constrained by improper agronomic management practices, such as inadequate dosage and application of fertilizers and overlong harvesting intervals, policy makers should focus on improving the public agricultural extension service and the availability of fertilizers through, for example, reducing transaction costs or providing fertilizer subsidies. Such measures should primarily focus on independent farmers as they show larger deficits in plantation management and offer a greater potential for yield increases. Specifically independent farmers are further constrained by restricted access to processing facilities and limited output marketing opportunities. Investments in infrastructure, the promotion of smallto medium-sized processing mills, and the promotion of smallholder marketing cooperatives are potential policy measures to improve smallholders' access to the processing industry.

From a rural development perspective, the specialization in oil palm agriculture potentially increases the livelihood vulnerability of oil palm smallholders and may reduce the local food sovereignty by reducing the diversity of agricultural production and by 
fostering a dependency on trade and markets to satisfy nutritional needs of the rural population. In particular, price shocks on international commodity markets might negatively affect the agricultural sector and the livelihoods of the agriculture-dependent population. These negative effects can only be mitigated through the diversification of the agricultural sector. The dependence on a small number of non-food cash crops might lead to a general decrease in the production diversity of agricultural products and a declining significance of subsistence food crops. In order to secure nutritional adequacy across the province, policy makers need to secure the functioning and accessibility of local food markets. These need to provide sufficient, safe and nutritious food items to satisfy the nutritional demand of the rural population.

\subsection{SCOPE FOR FUTURE RESEARCH}

It has been shown that village level attributes such as contractual ties to the oil palm industry are key determinants that shape the diffusion patterns of oil palm smallholdings. However, land use trajectories are likely to be determined by additional village characteristics, as well as by land use patterns, policies, and emerging institutions at the regional level. Future research on oil palm related land use changes should aim to combine detailed village level data including annual land use cover changes, the evolution of factor markets, and village institutions with remote sensing data that depict the dynamic nature of regional land use cover changes. Whereas smallholder oil palm adoption rates have started to decelarate in Jambi province, obtained results might be valuable in order to predict land use trajectories towards oil palm on Kalimantan and Papua, the new oil palm frontiers in Indonesia.

Oil palm cultivation was found to have positive welfare and nutritional effects among adopting households. However, the study has also found indications for unevenly distributed benefits associated with its cultivation. Future research should examine the underlying sources of such impact heterogeneity within the smallholder oil palm sector. Future studies should further analyze the wider socio-economic implications of oil palm agriculture by explicitly assessing its welfare effects on non-adopters and rural communities. Spillover effects of oil palm farming are likely to occur through changes in 
rural factor markets. These should be addressed explicitly when modelling impact pathways of oil palm cultivation.

A large potential for yield increases can be achieved by focusing on the inadequate use and dosage of fertilizers, as well as overlong harvesting intervals, as these are the major agronomic limitations in smallholder oil palm cultivation. Due to data limitations, information on oil palm cultivars was not included in the present study. Future research on smallholder yield potentials and agronomic constraints should aim at establishing a long-term data base that includes a wide range of agro-ecological settings and agronomic practices, also covering planted cultivars. Ideally, smallholder production is combined with the obtained fat contents and quality in harvested FFB. This can most easily be achieved by coorporating with different palm oil processors throughout the region.

Reconciling food security and rural development with the sustainable use of the global environmental resource base has widely been identified as one of the major challenges of present times. If implemented well, smallholder oil palm cultivation can be a powerful tool that supports economic development at low environmental costs. Future research therefore needs to provide knowledge-based production and diffusion scenarios that minimize the associated ecological externalities while maximizing its socio-economic benefits. 


\section{REFERENCES}

Abdulai, A., Huffman, W. 2005. The diffusion of new agricultural technologies: The case of crossbred-cow technology in Tanzania. American Journal of Agricultural Economics 87(3), 645-659.

Appleton, S., Song, L., Xia, Q. 2014. Understanding urban wage inequality in China 19882008: Evidence from quantile analysis. World Development 62, 1-13.

Babatunde, R.O., Qaim, M. 2010. Impact of off-farm income on food security and nutrition in Nigeria. Food Policy 35, 303-311.

Basiron, Y. 2002. Palm oil and its global supply and demand prospects. Oil Palm Industry Economic Journal 2(1), 1-10.

Basiron, Y. 2007. Palm oil production through sustainable plantations. European Journal of Lipid Science and Technology 109, 289-295.

Belcher B., Ndan lamng R., Achdiawan R. 2004. Rattan, rubber, or oil palm: Cultural and financial considerations for farmers in Kalimantan. Economic Botany 58, 77-87.

Berger, J., Blanchard, G., Campos Ponce, M., Chamnan, C., Chea, M., Dijkhuizen, M., Doak, C., Doets, E., Fahmida, U., Ferguson, E., Hulshof, P., Kameli, Y., Kuong, K., Akkhavong, K., Sengchanh, K., Mai Le, B., Lua Tran, T., Muslimatun, S., Roos, N., Sophonneary, P., Wieringa, F., Wasantwisut, E., Winichagoon, P. 2013. The SMILING project: A North-South-South collaborative action to prevent micronutrient deficiencies in women and young children in Southeast Asia. Food and Nutrition Bulletin 34(2), S133-S139.

BMKG 2014. Badan Meteorologi Klimatilogi dan Geofisika. Sultan Thaha Jambi wheather station data. Part of Automatic Weather System (AWS) database. Agency for Metereology, Climate and Geophysics, Jakarta. Retrieved on 17 November 2014 from http://aws.bmkg.go.id/MetView/\#dataquery.

BPS 2012. Badan Pusat Statistik. Jambi di dalam angka 2011. Statistical Office Indonesia, Jakarta. Retrieved on 10 February 2015 from http://jambiprov.go.id/images/jambi_angka/6894JDA2011.pdf. 
BPS 2014. Badan Pusat Statistik: Poverty module, Social and population database. Statistical Office Indonesia, Jakarta. Retrieved on 24 November 2014 from: http://www.bps.go.id/Subjek/view/id/23\#subjekViewTab3 |accordion-daftar-subjek1.

BPS 2015. Badan Pusat Statistik: Plantation module, Agriculture and mining database. Statistical Office Indonesia, Jakarta. Retrieved on 10 February 2015 from http://www.bps.go.id/eng/menutab.php?tabel=1\&kat=3\&id_subyek=54.

Buchinsky, M. 1998. Recent advances in quantile regression models: A practical guideline for empirical research. The Journal of Human Resources 33, 88-126.

Budidarsono, S., Dewi, S., Sofiyuddin, M., Rahmanulloh, A. 2012. Socioeconomic impact assessment of palm oil production. Technical Brief No. 24. World Agroforestry Centre (ICRAF), SEA Regional Office, Bogor, Indonesia. 4p.

Burton, M., Rigby, D., Young, T. 2003. Modeling the adoption of organic horticultural technology in the UK using duration analysis. Australian Journal of Agricultural and Resource Economics 47(1), 29-54.

Buttler, A., Laurence, W. 2009. Is oil palm the next emerging threat to the Amazon? Tropical Conservation Science 2(1), 1-10.

Cahyadi, E.R., Waibel, H. 2013. Is contract farming in the Indonesian oil palm industry pro-Poor? Journal of Southeast Asian Economics 30(1), 62-76.

Carrasco, L.R., Larrosa, C., Millner-Gulland, E.J., Edwards, D.P. 2014. A double-edged sword for tropical forests. Science 346(6205), 38-40.

Carter, C., Finley, W., Fry, J., Jackson, D., Willis, L. 2007. Palm oil markets and future supply. European Journal of Lipid Science and Technology 109, 307-314.

Cleves, M., Gutierrez, R., Gould, W., Marchenko, Y. 2002. An introduction to survival analysis using Stata. Stata Press, College Station, TX.

Corley, R.H.V., Tinker, P. 2003. The oil palm (4 ${ }^{\text {th }}$ edn). Blackwell Publishing, Hoboken, NJ. 592p.

Corley, R.H.V. 2009. How much palm oil do we need? Environmental Science \& Policy 12, 134-139.

Cox, D. 1972. Regression models and life-tables. Journal of the Royal Statistical Society 34(2), 187-220.

Cramb, R.A., Ferrano, D. 2010. Custom and capital: A financial appraisal of alternative arrangements for large-scale oil palm development on customary land in Sarawak, 
Malaysia. Australian Agricultural and Resource Economics Society, Canberra. Retrieved on 25 November from http://purl.umn.edu/59072.

Cramb, R. A., Curry, G.N. 2012. Oil palm and rural livelihoods in the Asia-Pacific region: An overview. Asia Pacific Viewpoint 53(3), 223-239.

Cramb, R.A. 2013. Palmed off: Incentive problems with joint-venture schemes for oil palm development on customary land. World Development 43, 84-99.

Dadi, L., Burton, B., Ozanne, A. 2004. Duration analysis of technological adoption in Ethiopian agriculture. Journal of Agricultural Economics 55(3), 613-631.

Danielsen, F., Beukema, H., Burgess, N., Parish, F., Bruehl, C., Donald, P. 2009. Biofuel plantations on forested lands: Double jeopardy for biodiversity and climate. Conservation Biology 23(2), 348-358.

D'Emden, F., Llewellyn, R., Burton, M. 2006. Adoption of conservation tillage in Australian cropping regions: An application of duration analysis. Technological Forecasting and Social Change 73(6), 630-647.

DKP, DPRI, WFP 2009. A food security and vulnerability atlas of Indonesia. Dewan Ketahanan Pangan, Jakarta; Departemen Pertanian RI, Jakarta; World Food Programme, Rome. Retrieved on 12 February 2015 from http://documents.wfp.org/stellent/groups/public/documents/ena/wfp236710.pdf.

Di Falco, S., Veronesi, M., Yesuf, M. 2011. Does adaptation to climate change provide food security? A micro-perspective from Ethiopia. American Journal of Agricultural Economics 93(3), 829-846.

Donough, C., Witt, C., Fairhurst, T. 2009. Yield intensification in oil palm plantations through best management practice. Better Crops 93, 12-14.

DPK 2011. Dinas Perkebunan. Estate statistics. Agency of estate crops of Jambi Province, Jambi.

Euler, M., Schwarze, S., Siregar, H. Qaim, M. 2015. Oil palm expansion among smallholder farmers in Sumatra, Indonesia. EFForTS Discussion Paper 8, Georg-August University of Goettingen, Goettingen.

FAO 2010. Guidelines for measuring household and individual dietary diversity. Food and Agricultural Organization, Rome. Retrieved on 10 February 2015 from http://www.fao.org/fileadmin/user_upload/wa_workshop/docs/FAO-guidelinesdietary-diversity2011.pdf. 
FAO 2014. The State of Food and Agriculture. Innovation in family farming. Food and Agricultural Organization, Rome. Retrieved on 17 March 2015 from http://www.fao.org/3/a-i4040e.pdf

FAO, IFAD, WFP 2014. The State of Food Insecurity in the World 2014.Strengthening the enabling environment for food security and nutrition. Food and Agricultural Organization, International Fund for Agricultural Development, World Food Program, Rome.

FAOSTAT 2014. Statistics division. Food and Agricultural Organization, Rome. Retrieved on 18 December 2014 from http://faostat.fao.org.

Faust, H., Schwarze, S., Beckert, B., Bruemmer, B., Dittrich, C., Euler, M., Gatto, M., Hauser-Schäublin, B., Hein, J., Ibanez, M., Klasen, S., Kopp, T., Holtkamp, A., Krishna, V., Kunz, Y., Lay, J., Musshoff, O., Qaim, M., Steinebach, S., Vorlaufer, M., Wollni, M. 2013. Assessment of socio-economic functions of tropical lowland transformation systems in Indonesia: Sampling framework and methodological approach. EFForTS Discussion Paper 1, Georg-August University of Goettingen, Goettingen.

Feintrenie, L., Chong, W.K., Levang, P. 2010. Why do farmers prefer oil palm? Lessons learnt from Bungo district, Indonesia. Small-Scale Forestry 9, 379-396.

Feintrenie, L., Levang, P. 2009. Sumatra's rubber agro-forests: Advent, rise and fall of a sustainable cropping system. Small-Scale Forestry 8(3), 323-335.

Fitzherbert, E., Struebig, M., Moerl, A., Danielsen, F., Bruehl, C., Donald, P., Phalan, B. 2008. How will oil palm expansion affect biodiversity? Trends in Ecology and Evolution 23(10), 538-545.

Foley, J., DeFries, R., Asner, G.P., Barford, C., Bonan, G., Carpenter, S.R., Chapin, F.S., Coe, M.T., Daily, G.C., Gibbs, H.K., Helkowski, J.H., Holloway, T., Howard, E.A., Kucharik, C.J., Monfreda, C., Patz, J.A., Prentice, I.C., Ramankutty, N., Snyder, P.K. 2005. Global consequences of land use. Science 309, 570-574.

Fuglie, K., Kascak, C. 2003. Adoption and diffusion of natural-resource-conserving agricultural technology. Review of Agricultural Economics 23(2), 386-403.

Garnett, T., Appleby, M.C., Balmford, A., Bateman, I.J., Benton, T.G., Bloomer, P., Burlingame, B., Dawkins, M., Dolan, L., Fraser, D., Herrero, M., Hoffman, I., Smith, P., Thornton, P.K., Toulmin, C., Vermeulen, S.J., Godfray, H.C.J. 2013. Sustainable Intensification in agriculture: Premises and policies. Science 341, 33-34.

Gatto, M., Wollni, M., Qaim, M. 2014. Oil palm boom and land-use dynamics in Indonesia: The role of policies and socio-economic factors. EFForTS Discussion Paper 6, Georg-August University of Goettingen, Goettingen. 
Gerbens-Leenes, P.W., Nonhebel, S. 2002. Consumption patterns and their effects on land required for food. Ecological Economics 42, 185-199.

Gerbens-Leenes, P.W., Nonhebel, S. 2004. Food and land use. The influence of consumption patterns on the use of agricultural resources. Appetite 45, 24-31.

Gibbs, H.K., Ruesch, A.S., Achard, F., Clayton, M.K., Holmgren, P., Rmankutty, N., Foley, J.A. 2010. Tropical forests were the primary sources of new agricultural land in the 1980s and 1990s. Proceedings of the National Academy of Sciences of the United States of America 107(38), 16732-16737.

Gilbert, N. 2012. Palm-oil boom raises conservation concerns. Nature 487, 14-15.

Godfray, H.C., Beddington, J.R., Crute, I.R., Haddad, L., Lawrence, D., Muir, J.F., Pretty, J., Robinson, S., Thomas, S.M., Toulmin, C. 2010. Food security: The challenge of feeding nine billion people. Science 327, 812-818.

Greene, W. H. 2008. Econometric Analysis ( $6^{\text {th }}$ ed). Prentice-Hall, Upper Saddle River, NJ. 1228p.

Grootaert, C., Narayan, D. 2004. Local institutions, poverty and household welfare in Bolivia. World development 32(7), 1179-1198.

Hartemik, A. 2005 Plantation agriculture in the tropics- environmental issues. Outlook on Agriculture 34, 11-21.

Hasnah, E.F., Coelli, T. 2004. Assessing the performance of a nucleus estate smallholder scheme for oil palm production in West Sumatra: A stochastic frontier analysis. Agricultural Systems 79, 17-30.

Hassine, N. B. 2015. Economic inequality in the Arab region. World Development 66, 532-556.

Hoffmann, M.P., Castaneda, V. A., van Wijk, M.T., Giller, K.E., Oberthür, T., Donough, C., Whitbread, A.M. 2014. Simulating potential growth and yield of oil palm (Elaeis guineensis) with PALMSIM: Model description, evaluation and application. Agricultural Systems 131, 1-10.

Ismail, A., Simeh, M.A., Noor, M.M. 2003. The production cost of oil palm fresh fruit bunches: The case of independent smallholders in Johor. Oil Palm Industry Economic Journal 3, 1-7.

ISPOC 2012. Indonesian Sustainable Palm Oil System. Indonesian palm oil in numbers 2012. Indonesian Sustainable Palm Oil Commission, Jakarta.

Jones, P.G., Thornton, P.K. 2013. Generating downscaled weather data from a suite of climate models for agricultural modelling applications. Agricultural Systems 114, 1-5. 
Jones, A.D., Shrinivas, A., Bezner-Kerr, R. 2014. Farm production diversity is associated with greater household dietary diversity in Malawi: Findings from nationally representative data. Food Policy 46, 1-12.

Kastner, T., Ibarrola Rivas, M.J., Koch, W., Nonhebel, S. 2012.Global changes in diets and the consequences for land requirements for food. Proceedings of the National Academy of Sciences of the United States of America 109(18), 6868-6872.

Kearney, J. 2010. Food consumption trends and drivers. Philosophical Transactions of the Royal Society B 365, 2793-2807.

Key, N., Roberts, M. 2006. Government payments and farm business as usual. American Journal of Agricultural Economics 88(2), 382-392.

Kiefer, N. 1988. Economic duration data and hazard functions. Journal of Economic Literature 26(2), 646-679.

Kitzes, J., Wackernagel, M., Loh, J., Peller, A., Goldfinger, S., Cheng, D., Tea, K. 2008. Shrink and share: humanity's present and future ecological footprint. Philosophical Transactions of the Royal Society B 363, 467-475.

Koenker, R., Basset, G. 1978. Regression quantiles. Econometrica 46(1), 33-50.

Koenker, R., Hallock, K.F. 2001. Quantile Regression. Journal of Economic Perspectives 15(4), 143-156.

Koh, L., Wilcove, D. 2008. Is oil palm agriculture really destroying tropical biodiversity? Conservation Letters 1(2), 60-64.

Koh, L.P., Lee, T.M. 2012. Sensible consumerism for environmental sustainability. Biological Conservation 151, 3-6.

Krishna, V.V., Pascual, U., Qaim, M. 2014. Do emerging land markets promote forestland appropriation? Evidence from Indonesia. EFForTS Discussion Paper 7, Georg-AugustUniversity of Goettingen, Goettingen.

Krishna, V.V., Euler, M., Siregar, H.,Fathoni, Z., Qaim, M. 2015. Farmer heterogeneity and differential livelihood impacts of oil palm expansion among smallholders in Sumatra, Indonesia. EFForTS Discussion Paper 13, Georg-August-University of Goettingen, Goettingen.

Lambin, E.F., Meyfroidt, P. 2011. Global land use change, economic globalization, and the looming land scarcity. Proceedings of the National Academy of Sciences of the United States of America 108(9), 3465-3472.

Lancaster, T. 1972. A stochastic model for the duration of a strike. Journal of the Royal Statistical Society 135(2), 257-271. 
Laurence, W.F., Sayer, J., Cassman, K.G. 2014. Agricultural expansion and its impacts on tropical nature. Trends in Ecology \& Evolution 29(2), 107-116.

Lee, J.S.H., Ghazoul, J., Obidzinski, K., Koh, L.P. 2014. Oil palm smallholder yields and incomes constrained by harvesting practices and type of smallholder management in Indonesia. Agronomy for Sustainable Development 34(2), 501-513.

Margono, A., Potapov, P., Turubanova, S., Stolle, F., Hansen, M. 2014. Primary forest cover loss in Indonesia over 2000-2012. Nature Climate Change 4, 730-735.

Matuschke, I., Qaim, M. 2008. Seed market privatization and farmers' access to crop technologies: The case of hybrid pearl millet adoption in India. Journal of Agricultural Economics 59(3), 498-515.

McCarthy, J. 2000. The changing regime: Forest property and reformasi in Indonesia. Development and Change 31, 91-129.

McCarthy, J. 2007. Shifting resource entitlements and governance reform during the agrarian transition in Sumatra, Indonesia. Journal of Legal Pluralism 55, 95-121.

McCarthy, J., Cramb, R. 2009. Policy narratives, landholder engagement, and oil palm expansion on the Malaysian and Indonesian frontiers. Geographical Journal 175(2), 112-123.

McCarthy, J. 2010. Processes of inclusion and adverse incorporation: Oil palm and agrarian change in Sumatra, Indonesia. The Journal of Peasant Studies 37(4), 821-850.

McWilliams, B., Zilberman, D. 1996. Time of technology adoption and learning by using. Economics of Innovation and New Technology 4(2), 139-154.

Miyamoto, M. 2006. Forest conversion to rubber around Sumatran villages in Indonesia: Comparing the impacts of road construction, transmigration projects and population. Forest Policy and Economics 9(1), 1-12.

Morton, J. 2007. The impact of climate change on smallholder and subsistence agriculture. Proceedings of the National Academy of Sciences of the United States of America 104(50), 19680-19685.

MPW, WFP, BPS, AusAID (2006). Nutrition Map of Indonesia. Small area estimation of nutritional status in Indonesia. Indonesian Ministry of the People's Welfare, Jakarta; World Food Programme, Rome; Badan Pusat Statistik, Jakarta; Australian Agency for International Development, Canberra. Retrieved on 8 February 2015 from http://documents.wfp.org/stellent/groups/public/documents/ena/wfp246494.pdf. 
Murphy, D.J. 2007. Future prospects for oil palm in the $21^{\text {st }}$ century: Biological and related challenges. European Journal of Lipid Science and Technology 109, 296-306.

Nickell, S. 1979. Estimating the probability of leaving unemployment. Econometrica 47(5), 1249-1266.

Nguyen, B. T., Albrecht, J. W., Vroman, S. B., Westbrook, M. D. 2007. A quantile regression decomposition of urban-rural inequality in Vietnam. Journal of Development Economics 83(2), 466-490.

OECD 1982. The OECD List of Social Indicators. The social indicator development programme, The Organization for Economic Co-operation and Development. OECD Publishing, Paris. 124p.

OECD, FAO (2011). OECD-FAO Agricultural Outlook 2011-2020. The Organization for Economic Co-operation and Development, Paris; Food and Agricultural Organization, Rome. Retrieved on 8 February 2015 from http://dx.doi.org/10.1787/agr_outlook2011-en.

Pellegrini, L., Tasciotti, L. 2014. Crop diversification, dietary diversity and agricultural income: Empirical evidence from eight developing countries. Canadian Journal of Development Studies 35(2) 211-227.

Phelps, J., Carrasco, L.R., Webb, E.L., Koh, L.P. Pascual, U. 2013. Agricultural intensification escalates future conservation costs. Proceedings of the National Academy of Sciences of the United States of America 110 (19), 7601-7606.

Pingali, P.L. 2012. Green Revolution: Impacts, limits, and the path ahead. Proceedings of the National Academy of Sciences of the United States of America 109(31), 1230212308.

Qaim, M., Kouser, S. 2013. Genetically modified crops and food security. PLoS ONE 8(6), e64879.

Rahmat, S.R. 2013. Gross margin analysis for palm oil industry in Malaysia: Case study Johor, Malaysia. International Journal of Innovations in Business 2, 778-791.

Rist, L., Feintrenie, L., Levang, P. 2010. The livelihood impacts of oil palm: Smallholders in Indonesia. Biodiversity and Conservation 19(4), 1009-1024.

RSPO 2013. Roundtable on Sustainable Palm Oil. Principles and criteria for the production of sustainable palm oil. RSPO Secretariat, Kuala Lumpur, Malaysia. 
RSPO 2014. Roundtable on Sustainable Palm Oil. Impact Report 2014. RSPO Secretariat, Kuala Lumpur, Malaysia.

Sanglestsawai, S., Rejesus, R. M., Yorobe, J. M. 2014. Do lower yielding farmers benefit from Bt corn? Evidence from instrumental variable quantile regressions. Food Policy 44, 285-296.

Sayer, J., Ghazoul, J., Nelson, P., Boedhihartono, A.K. 2012. Oil palm expansion transforms tropical landscapes and livelihoods. Global Food Security 1, 114-119.

Schipmann, C., Qaim, M. 2010. Spillovers from modern supply chains to traditional markets: Product innovation and adoption by smallholders. Agricultural Economics 41(3-4), 361-371.

Sheil, D., Casson, A., Meijaard, E., van Noordwijk, M., Gaskell, J., Sunderland-Groves, J., Wertz, K., Kanninen, M. 2009. The impacts and opportunities of oil palm in Southeast Asia: What do we know and what do we need to know? Occasional paper no. 51, Center for International Forestry Research (CIFOR), Bogor.

Singer, J., Willet, J. 1993. It's about time: Using discrete-time survival analysis to study duration and the timing of events. Journal of Educational Studies 18(2), 155-195.

Stevenson, J., Villoria, N., Byerlee, D., Kelley, T., Maredia, M. 2013. Green Revolution research saved an estimated 18 to 27 million hectares from being brought into agricultural production. Proceedings of the National Academy of Sciences of the United States of America 110(21), 8363-8368.

Tilman, D. 1999. Global environmental impacts of agricultural expansion: The need for sustainable and efficient practices. Proceedings of the National Academy of Sciences of the United States of America 96, 5995-6000.

Tilman, D., Fargione, J., Wolff, B., D’Antonio, C., Dobson, A., Howarth, R., Schindler, D., Schlesinger, W.H., Simberloff, D., Swackhamer, D. 2001. Forecasting agriculturally driven global environmental change. Science 292, 281-284.

van Ittersum, M.K., Cassman, K.G., Grassini, P., Wolf, J., Tittonell, P., Hochman, Z. 2013. Yield gap analysis with local to global relevance: A review. Field Crops Research 143, 4-17.

Vermeulen, S., Goad, N. 2006. Towards better practice in smallholder palm oil production. Natural Resource Issue Series, 5. International Institute for Environment and Development, London.

Villoria, N.B., Golub, A., Byerlee, D., Stevenson, J. 2013. Will yield improvements on the forest frontier reduce greenhouse gas emissions? A global analysis of oil palm. American Journal of Agricultural Economics 95, 1301-1308. 
von Braun, J. 1995. Agricultural commercialization: Impacts on income and nutrition and implications for policy. Food Policy 20(3), 187-202.

von Braun, J. 2007. The world food situation. New driving forces and required actions. Food Policy Report. International Food Policy Research Institute (IFPRI), Washington, D.C.

Wahid, M.B., Akmar Abdullah, S.N., Henson, I.E. 2005. Oil palm- achievements and potential. Plant Production Science 8(3), 288-297.

West, P.C., Gerber, J.S., Engstrom, P.M., Mueller, N.D., Brauman, K.A., Carlson, K.M., Cassidy, E.S., Johnston, M., MacDonald, G.K., Ray, D.K., Siebert, S. 2014. Leverage points for improving global food security and the environment. Science 345, 325-328.

Wheeler, T. von Braun, J. 2013. Climate change impacts on global food security. Science 341, 508-513.

Wheeler, D., Hammer, D., Kraft, R., Dasgupta, S., Blankespoor, B. 2013. Economic dynamics and forest clearing: A spatial econometric analysis for Indonesia. Ecological Economics 85, 85-96.

Wigena, I., Siregar, H., Sudrajat, S. 2009. Design of sustainable management model of nucleus smallholders of oil palm based dynamic system approach. Jurnal Agro Ekonomi 27(1), 81-108.

Wilcove, D., Koh, L. 2010. Addressing the threats to biodiversity from oil-palm agriculture. Biodiversity and Conservation 19(4), 999-1007.

World Bank 2007. From agriculture to nutrition. Pathways, synergies and outcomes. The World Bank, Washington D.C., USA.

World Bank 2008. World development report 2008. Agriculture for development. The World Bank, Washington D.C., USA.

World Bank 2011. The World Bank Group framework and IFC strategy in the palm oil sector. The World Bank, Washington D.C., USA. Retrieved on 24 November from http://www.ifc.org/wps/wcm/connect/159dce004ea3bd0fb359f71dc0e8434d/WB G+Framework+and+IFC+Strategy_FINAL_FOR+WEB.pdf?MOD=AJPERES.

World Bank 2015. Online data base. World Bank, Washington D.C., USA. Retrieved on 21 February from http://data.worldbank.org/indicator/PA.NUS.FCRF/countries?page=4\&display=defaul t.

World Food Programme 2009. Climate change and hunger. Responding to the challenge. World Food Programme, Rome, Italy. 
You, W.-H., Zhu, H.-M., Yu, K., Peng, C. 2015. Democracy, financial openness and global carbon dioxide emissions: Heterogeneity across existing emission levels. World Development 66, 189-207.

Zen, Z., Barlow, C., Gondowarsito, R. 2006. Oil Palm in Indonesian Socio-Economic Improvement- A Review of Options. Oil Palm Industry Economic Journal 6, 18-29. 


\section{APPENDIX A: AdDITIONAL TABLES}

Table A1. Estimation results of reduced form OLS models with regression of dependent variables on instrumental variables for the group of non-adopters only.

\begin{tabular}{|c|c|c|c|c|c|}
\hline & $\begin{array}{c}\text { Total annual } \\
\text { consumption } \\
\text { expenditure } \\
\text { (000 IDR/AE) }\end{array}$ & $\begin{array}{l}\text { Annual non- } \\
\text { food } \\
\text { expenditure } \\
\text { (000 IDR/AE) }\end{array}$ & $\begin{array}{l}\text { Annual food } \\
\text { expenditure } \\
\text { (000 IDR/AE) }\end{array}$ & $\begin{array}{c}\text { Daily calorie } \\
\text { consumption } \\
(\text { kcal/AE })\end{array}$ & $\begin{array}{c}\text { Daily calorie } \\
\text { consumption } \\
\text { nutritious } \\
\text { (kcal/AE) }\end{array}$ \\
\hline $\begin{array}{l}\text { Years of } \\
\text { farming in } \\
\text { contract } \\
\text { village }\end{array}$ & $\begin{array}{l}-21.2 \\
(81.1)\end{array}$ & $\begin{array}{l}-37.1 \\
(63.1)\end{array}$ & $\begin{array}{l}15.9 \\
(29.9)\end{array}$ & $\begin{array}{c}9.1 \\
(13.0)\end{array}$ & $\begin{array}{c}0.8 \\
(6.7)\end{array}$ \\
\hline $\begin{array}{l}\text { Village with oil } \\
\text { palm in } \\
1992 \\
\text { (dummy) }\end{array}$ & $\begin{array}{c}763.9 \\
(1048.3)\end{array}$ & $\begin{array}{c}348.2 \\
(898.6)\end{array}$ & $\begin{array}{c}415.8 \\
(370.4)\end{array}$ & $\begin{array}{c}79.6 \\
(149.0)\end{array}$ & $\begin{array}{l}-19-3 \\
(76.3)\end{array}$ \\
\hline $\begin{array}{l}\text { Model } \\
\text { intercept }\end{array}$ & $\begin{array}{c}13319.4^{* * *} \\
(435.4)\end{array}$ & $\begin{array}{c}7092.7^{* * *} \\
(361.3)\end{array}$ & $\begin{array}{c}6226.6^{* * *} \\
(148.7)\end{array}$ & $\begin{array}{c}2862.0^{* * *} \\
(62.5)\end{array}$ & $\begin{array}{c}996.4^{* * *} \\
(32.7)\end{array}$ \\
\hline $\begin{array}{l}\text { No. of } \\
\text { observations }\end{array}$ & 465 & 465 & 465 & 465 & 465 \\
\hline $\begin{array}{l}\mathrm{F} \\
\text { Adi. } \mathrm{R}^{2}\end{array}$ & $\begin{array}{l}0.29 \\
<0.01\end{array}$ & $\begin{array}{l}0.24 \\
<0.01\end{array}$ & $\begin{array}{l}0.73 \\
<0.01\end{array}$ & $\begin{array}{c}0.35 \\
<0.01\end{array}$ & $\begin{array}{c}0.04 \\
<0.01\end{array}$ \\
\hline
\end{tabular}

Notes: Standard errors are shown in parenthesis. ${ }^{* * *}$ indicate $1 \%$ level of significance testing that intercept estimates are equal to zero. 
Table A2. Estimation results of endogenous treatment effects model.

\begin{tabular}{|c|c|c|c|c|c|c|}
\hline & \multicolumn{2}{|c|}{$\begin{array}{c}\text { Total annual consumption } \\
\text { expenditure } \\
\text { (000 IDR/AE) }\end{array}$} & \multicolumn{2}{|c|}{$\begin{array}{l}\text { Annual non-food } \\
\text { expenditure } \\
\text { (000 IDR/AE) }\end{array}$} & \multicolumn{2}{|c|}{$\begin{array}{l}\text { Annual food expenditure } \\
\text { (000 IDR/AE) }\end{array}$} \\
\hline & $\begin{array}{l}\text { Selection } \\
\text { equation }\end{array}$ & $\begin{array}{l}\text { Outcome } \\
\text { equation }\end{array}$ & $\begin{array}{l}\text { Selection } \\
\text { equation }\end{array}$ & $\begin{array}{l}\text { Outcome } \\
\text { equation }\end{array}$ & $\begin{array}{l}\text { Selection } \\
\text { equation }\end{array}$ & $\begin{array}{l}\text { Outcome } \\
\text { equation }\end{array}$ \\
\hline $\begin{array}{l}\text { Oil palm adoption } \\
\text { (dummy) }\end{array}$ & & $\begin{array}{c}5564.93 \\
(3666.41)\end{array}$ & & $\begin{array}{c}4232.79 \\
(3324.62)\end{array}$ & & $\begin{array}{l}1138.32^{*} \\
(679.50)\end{array}$ \\
\hline $\begin{array}{l}\text { Area under rubber } \\
\text { (ha) }\end{array}$ & $\begin{array}{l}-0.05^{*} \\
(0.03)\end{array}$ & $\begin{array}{l}941.78^{* * *} \\
(165.08)\end{array}$ & $\begin{array}{l}-0.05^{*} \\
(0.03)\end{array}$ & $\begin{array}{l}665.12^{* * *} \\
(153.63)\end{array}$ & $\begin{array}{l}-0.05^{*} \\
(0.03)\end{array}$ & $\begin{array}{l}274.04^{* * *} \\
(47.94)\end{array}$ \\
\hline $\begin{array}{l}\text { Age of household head } \\
\text { (years) }\end{array}$ & $\begin{array}{c}1 E-03 \\
(5 E-03)\end{array}$ & $\begin{array}{l}-9.06 \\
(26.85)\end{array}$ & $\begin{array}{c}1 \mathrm{E}-03 \\
(5 \mathrm{E}-03)\end{array}$ & $\begin{array}{l}-25.31 \\
(22.44)\end{array}$ & $\begin{array}{c}1 \mathrm{E}-03 \\
(5 \mathrm{E}-03)\end{array}$ & $\begin{array}{l}16.49^{*} \\
(9.88)\end{array}$ \\
\hline $\begin{array}{l}\text { Education } \\
\text { (years of schooling) }\end{array}$ & $\begin{array}{l}0.05^{* * *} \\
(0.02)\end{array}$ & $\begin{array}{l}235.22^{* *} \\
(110.63)\end{array}$ & $\begin{array}{l}0.05^{* * *} \\
(0.02)\end{array}$ & $\begin{array}{l}137.64 \\
(96.35)\end{array}$ & $\begin{array}{l}0.05^{* * *} \\
(0.02)\end{array}$ & $\begin{array}{l}99.62^{* * *} \\
(34.86)\end{array}$ \\
\hline $\begin{array}{l}\text { Household size } \\
(\mathrm{AE})\end{array}$ & $\begin{array}{c}0.10 \\
(0.06)\end{array}$ & $\begin{array}{l}-1254.70^{* * *} \\
(294.75)\end{array}$ & $\begin{array}{c}0.10 \\
(0.06)\end{array}$ & $\begin{array}{l}-759.08^{* * *} \\
(242.49)\end{array}$ & $\begin{array}{l}0.10^{*} \\
(0.06)\end{array}$ & $\begin{array}{l}-493.24^{* * *} \\
(103.98)\end{array}$ \\
\hline $\begin{array}{l}\text { Household head } \\
\text { migrated to place of } \\
\text { residence(dummy) }\end{array}$ & $\begin{array}{c}0.12 \\
(0.16)\end{array}$ & $\begin{array}{c}8.90 \\
(927.34)\end{array}$ & $\begin{array}{c}0.13 \\
(0.16)\end{array}$ & $\begin{array}{c}54.91 \\
(844.18)\end{array}$ & $\begin{array}{c}0.12 \\
(0.16)\end{array}$ & $\begin{array}{c}-34.59 \\
(254.91)\end{array}$ \\
\hline $\begin{array}{l}\text { Household head } \\
\text { originates from } \\
\text { Sumatra (dummy) }\end{array}$ & $\begin{array}{l}-0.10 \\
(0.17)\end{array}$ & $\begin{array}{l}-1441.91 \\
(968.82)\end{array}$ & $\begin{array}{l}-0.10 \\
(0.18)\end{array}$ & $\begin{array}{l}-830.82 \\
(880.17)\end{array}$ & $\begin{array}{l}-0.12 \\
(0.16)\end{array}$ & $\begin{array}{l}-606.72^{* *} \\
(283.43)\end{array}$ \\
\hline $\begin{array}{l}\text { Household resides in } \\
\text { trans-migrant village } \\
\text { (dummy) }\end{array}$ & $\begin{array}{c}0.20 \\
(0.23)\end{array}$ & $\begin{array}{l}-1301.92 \\
(1793.53)\end{array}$ & $\begin{array}{c}0.20 \\
(0.23)\end{array}$ & $\begin{array}{l}-793.50 \\
(1630.29)\end{array}$ & $\begin{array}{c}0.18 \\
(0.22)\end{array}$ & $\begin{array}{l}-446.83 \\
(385.72)\end{array}$ \\
\hline $\begin{array}{l}\text { Household resides in } \\
\text { mixed village } \\
\text { (dummy) }\end{array}$ & $\begin{array}{l}0.57^{* *} \\
(0.27)\end{array}$ & $\begin{array}{c}-898.93 \\
(1621.31)\end{array}$ & $\begin{array}{l}0.57^{* *} \\
(0.27)\end{array}$ & $\begin{array}{c}-348.64 \\
(1392.78)\end{array}$ & $\begin{array}{l}0.58^{* *} \\
(0.27)\end{array}$ & $\begin{array}{l}-494.88 \\
(560.78)\end{array}$ \\
\hline $\begin{array}{l}\text { Distance to nearest } \\
\text { market place }(\mathrm{km})\end{array}$ & $\begin{array}{l}4 \mathrm{E}-03 \\
(0.01)\end{array}$ & $\begin{array}{l}-74.61^{*} \\
(45.31)\end{array}$ & $\begin{array}{l}4 \mathrm{E}-03 \\
(0.01)\end{array}$ & $\begin{array}{l}-48.90 \\
(40.34)\end{array}$ & $\begin{array}{l}4 E-03 \\
(0.01)\end{array}$ & $\begin{array}{l}-27.12^{* *} \\
(11.82)\end{array}$ \\
\hline $\begin{array}{l}\text { Random village } \\
\text { (dummy) }\end{array}$ & $\begin{array}{l}-0.28 \\
(0.23)\end{array}$ & $\begin{array}{c}1590.08 \\
(1493.84)\end{array}$ & $\begin{array}{l}-0.28 \\
(0.23)\end{array}$ & $\begin{array}{c}1369.95 \\
(1346.66)\end{array}$ & $\begin{array}{l}-0.27 \\
(0.22)\end{array}$ & $\begin{array}{c}177.15 \\
(419.47)\end{array}$ \\
\hline Household resides in... & & & & & & \\
\hline $\begin{array}{l}\text { Batanghari } \\
\text { (dummy) }\end{array}$ & $\begin{array}{l}-0.18 \\
(0.19)\end{array}$ & $\begin{array}{l}-3484.88^{* * *} \\
(1103.31)\end{array}$ & $\begin{array}{l}-0.18 \\
(0.19)\end{array}$ & $\begin{array}{c}-1726.45^{*} \\
(962.93)\end{array}$ & $\begin{array}{l}-0.18 \\
(0.19)\end{array}$ & $\begin{array}{c}-1735.48^{* * *} \\
(354.67)\end{array}$ \\
\hline $\begin{array}{l}\text { Muaro Jambi } \\
\text { (dummy) }\end{array}$ & $\begin{array}{l}-0.16 \\
(0.27)\end{array}$ & $\begin{array}{l}-2762.64^{* *} \\
(1323.5)\end{array}$ & $\begin{array}{l}-0.15 \\
(0.27)\end{array}$ & $\begin{array}{l}-1684.37 \\
(1140.84)\end{array}$ & $\begin{array}{l}-0.14 \\
(0.26)\end{array}$ & $\begin{array}{l}-1042.82^{* *} \\
(503.18)\end{array}$ \\
\hline $\begin{array}{l}\text { Tebo } \\
\text { (dummy) }\end{array}$ & $\begin{array}{l}-0.86^{* * *} \\
(0.26)\end{array}$ & $\begin{array}{l}-2067.58 \\
(1475.21)\end{array}$ & $\begin{array}{l}-0.87^{* * *} \\
(0.26)\end{array}$ & $\begin{array}{c}-656.67 \\
(1329.89)\end{array}$ & $\begin{array}{l}-0.86^{* * *} \\
(0.26)\end{array}$ & $\begin{array}{r}-1440.52^{* * *} \\
(389.39)\end{array}$ \\
\hline $\begin{array}{l}\text { Bungo } \\
\text { (dummy) }\end{array}$ & $\begin{array}{l}-0.76^{* * *} \\
(0.23)\end{array}$ & $\begin{array}{l}-3169.86^{* * *} \\
(1231.63)\end{array}$ & $\begin{array}{l}-0.75^{* * *} \\
(0.23)\end{array}$ & $\begin{array}{l}-1826.98^{*} \\
(1046.32)\end{array}$ & $\begin{array}{l}-0.75^{* * * *} \\
(0.23)\end{array}$ & $\begin{array}{l}-1351.89 \\
(408.99)\end{array}$ \\
\hline $\begin{array}{l}\text { Years of farming in } \\
\text { contract village (no.) }\end{array}$ & $\begin{array}{l}0.07^{* * *} \\
(0.01)\end{array}$ & & $\begin{array}{l}0.07^{* * *} \\
(0.01)\end{array}$ & & $\begin{array}{l}0.07^{* * *} \\
(0.01)\end{array}$ & \\
\hline $\begin{array}{l}\text { Village with oil palm in } \\
1992 \text { (dummy) }\end{array}$ & $\begin{array}{l}0.67^{* * *} \\
(0.16)\end{array}$ & & $\begin{array}{l}0.67^{* * *} \\
(0.16)\end{array}$ & & $\begin{array}{l}0.67^{* * *} \\
(0.16)\end{array}$ & \\
\hline Model intercept & $\begin{array}{c}-1.22^{* * *} \\
(0.42)\end{array}$ & $\begin{array}{c}15889.63^{* * *} \\
(2528.97)\end{array}$ & $\begin{array}{l}-1.24^{* * *} \\
(0.42)\end{array}$ & $\begin{array}{l}8616.44^{* * *} \\
(2311.22)\end{array}$ & $\begin{array}{l}-1.24^{* * *} \\
(0.42)\end{array}$ & $\begin{array}{c}1138.32^{* * *} \\
(679.50)\end{array}$ \\
\hline$\sigma_{j}$ & $\begin{array}{c}7690.91^{* * *} \\
(496.86)\end{array}$ & & $\begin{array}{l}6739.92^{* * *} \\
(521.33)\end{array}$ & & $\begin{array}{c}2562.85^{* * *} \\
(98.80)\end{array}$ & \\
\hline$\rho_{j}$ & $\begin{array}{l}-0.18 \\
(0.32)\end{array}$ & & $\begin{array}{l}-0.16 \\
(0.33)\end{array}$ & & $\begin{array}{l}-0.07 \\
(0.16)\end{array}$ & \\
\hline $\begin{array}{l}\text { Wald } \mathrm{Chi}^{2} \\
\text { Log Likelihood }\end{array}$ & & $\begin{array}{l}55 \\
7.38\end{array}$ & & & & \\
\hline $\begin{array}{l}\text { Wald test of } \\
\text { independent eq. } \chi^{2}(1)\end{array}$ & & & & & & \\
\hline
\end{tabular}

Notes: $n=664$. Standard errors are shown in parenthesis. ${ }^{*},{ }^{* *},{ }^{* * *}$ indicate $10 \%, 5 \%$ and $1 \%$ level of significance testing that coefficients are equal to zero. 
Table A3. Estimation results of endogenous treatment effects model.

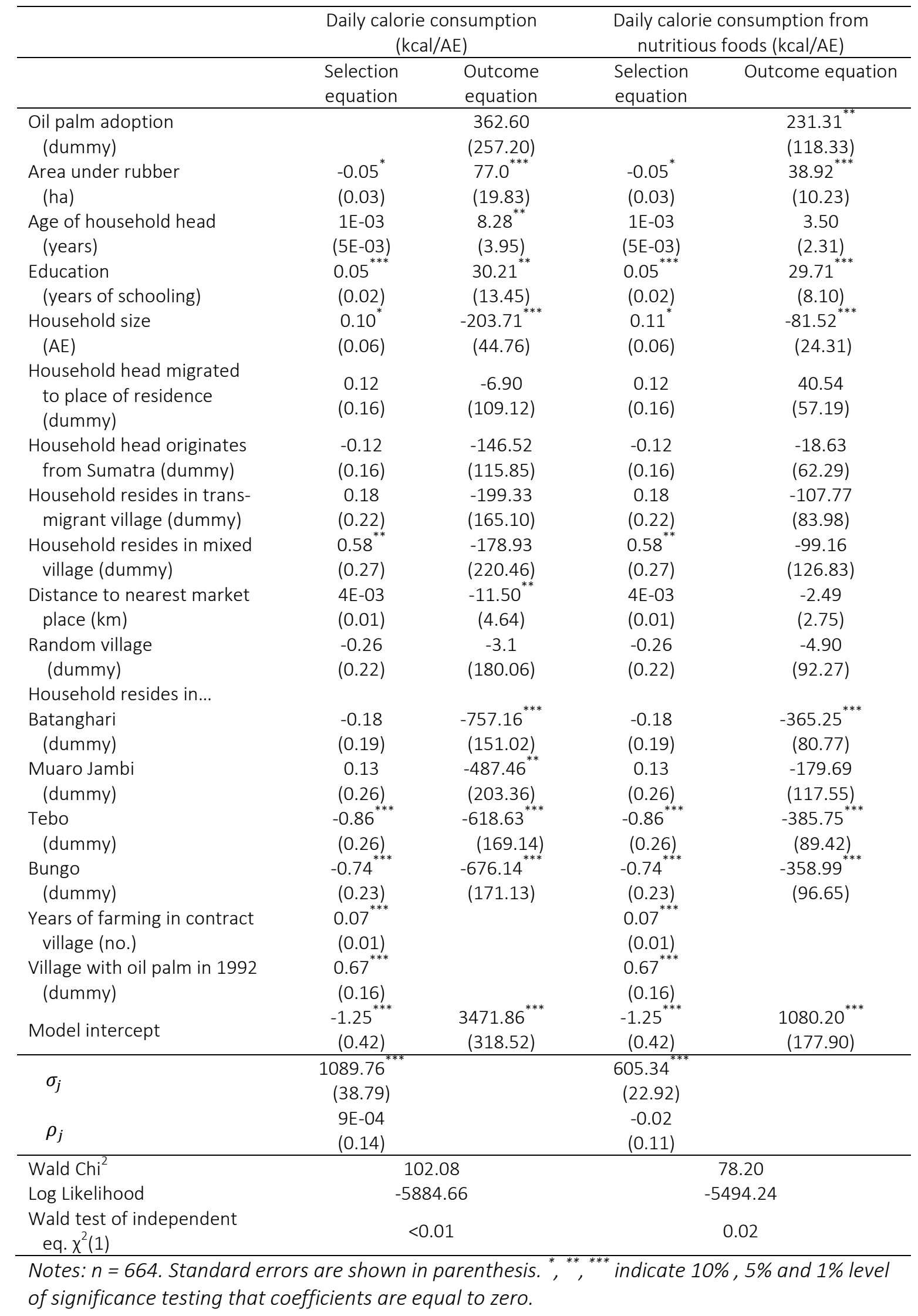


Table A4. Estimation results of OLS regressions for household expenditure and calorie consumption with alternative model specifications.

\begin{tabular}{|c|c|c|c|c|c|}
\hline & $\begin{array}{l}\text { Total annual } \\
\text { consumption } \\
\text { expenditure } \\
\text { (000 IDR/AE) }\end{array}$ & $\begin{array}{l}\text { Annual non- } \\
\text { food } \\
\text { expenditure } \\
\text { (000 IDR/AE) }\end{array}$ & $\begin{array}{c}\text { Annual food } \\
\text { expenditure } \\
(000 \\
\text { IDR/AE) }\end{array}$ & $\begin{array}{c}\text { Daily calorie } \\
\text { consumption } \\
(\text { kcal/AE })\end{array}$ & $\begin{array}{c}\text { Daily calorie } \\
\text { consumption } \\
\text { nutritious foods } \\
\text { (kcal/AE) }\end{array}$ \\
\hline $\begin{array}{l}\text { Oil palm area } \\
\text { (ha) }\end{array}$ & $\begin{array}{l}948.9^{* * *} \\
(216.8)\end{array}$ & $\begin{array}{l}618.1^{* * *} \\
(187.9)\end{array}$ & $\begin{array}{c}330.8^{* * *} \\
(89.6)\end{array}$ & $\begin{array}{c}106.0^{* * *} \\
(36.5)\end{array}$ & $\begin{array}{c}61.3^{* * *} \\
(19.0)\end{array}$ \\
\hline $\begin{array}{l}\text { Rubber area } \\
\text { (ha) }\end{array}$ & $\begin{array}{l}900.7^{* * *} \\
(163.1)\end{array}$ & $\begin{array}{l}630.1^{* * *} \\
(151.0)\end{array}$ & $\begin{array}{c}270.6^{* * *} \\
(47.8)\end{array}$ & $\begin{array}{l}75.9^{* * *} \\
(19.7)\end{array}$ & $\begin{array}{l}38.0^{* * *} \\
(10.0)\end{array}$ \\
\hline $\begin{array}{l}\text { Model } \\
\text { intercept }\end{array}$ & $\begin{array}{c}17743.9^{* * *} \\
(2401.1)\end{array}$ & $\begin{array}{l}9945.6^{* * *} \\
(2154.7)\end{array}$ & $\begin{array}{c}7798.3^{* * *} \\
(789.1)\end{array}$ & $\begin{array}{c}3627.3^{* * *} \\
(330.6)\end{array}$ & $\begin{array}{c}1174.4^{* * *} \\
(184.1)\end{array}$ \\
\hline $\begin{array}{l}\text { Regency level } \\
\text { fixed effects } \\
\text { included }\end{array}$ & Yes & Yes & Yes & Yes & Yes \\
\hline $\begin{array}{l}\text { No. of } \\
\text { observation } \\
\text { s }\end{array}$ & 664 & 664 & 664 & 664 & 664 \\
\hline $\mathrm{F}$ & 8.79 & 5.15 & 8.00 & 6.78 & 5.74 \\
\hline Adj. $R^{2}$ & 0.17 & 0.10 & 0.20 & 0.15 & 0.14 \\
\hline
\end{tabular}

Notes: Standard errors are shown in parenthesis. Oil palm adoption only includes farmers cultivating productive oil palm plots. Area under oil palm and rubber only includes productive plots. Additional covariates used in the model are age, education level, ethnicity and migration background of the household head, household size, distance to the closest market place, village type and mode of village selection; ${ }^{*},{ }^{* *},{ }^{* * *}$ indicate $10 \%, 5 \%$ and $1 \%$ level of significance testing that coefficients are equal to zero. 
Table A5. Estimation results of OLS regressions for household consumption expenditure and calorie consumption with alternative model specifications.

\begin{tabular}{|c|c|c|c|c|c|}
\hline & $\begin{array}{l}\text { Total annual } \\
\text { consumption } \\
\text { expenditure } \\
\text { (000 IDR/AE) }\end{array}$ & $\begin{array}{l}\text { Annual non- } \\
\text { food } \\
\text { expenditure } \\
\text { (000 IDR/AE) }\end{array}$ & $\begin{array}{l}\text { Annual food } \\
\text { expenditure } \\
\text { (000 IDR/AE) }\end{array}$ & $\begin{array}{c}\text { Daily calorie } \\
\text { consumption } \\
\text { (kcal/AE) }\end{array}$ & $\begin{array}{c}\text { Daily calorie } \\
\text { consumption } \\
\text { from nutritious } \\
\text { foods (kcal/AE) }\end{array}$ \\
\hline $\begin{array}{l}\text { Oil palm } \\
\text { adoption } \\
\text { (dummy) }\end{array}$ & $\begin{array}{l}1242.53^{*} \\
(711.55)\end{array}$ & $\begin{array}{c}925.82 \\
(617.66)\end{array}$ & $\begin{array}{c}316.75 \\
(262.74)\end{array}$ & $\begin{array}{l}209.47^{*} \\
(113.03)\end{array}$ & $\begin{array}{l}144.94^{* *} \\
(68.52)\end{array}$ \\
\hline $\begin{array}{l}\text { Total farm } \\
\text { size (ha) }\end{array}$ & $\begin{array}{l}682.43^{* * *} \\
(105.67)\end{array}$ & $\begin{array}{c}496.93^{* * *} \\
(91.79)\end{array}$ & $\begin{array}{c}185.50^{* * *} \\
(40.64)\end{array}$ & $\begin{array}{l}52.99^{* * *} \\
(16.69)\end{array}$ & $\begin{array}{c}21.56^{* * *} \\
(7.88)\end{array}$ \\
\hline $\begin{array}{l}\text { Off-farm } \\
\text { income } \\
\text { (million } \\
\text { IDR/AE) }\end{array}$ & $\begin{array}{l}165.14^{* * *} \\
(37.66)\end{array}$ & $\begin{array}{c}148.28^{* * *} \\
(31.47)\end{array}$ & $\begin{array}{c}16.85 \\
(11.92)\end{array}$ & $\begin{array}{c}3.30 \\
(4.91)\end{array}$ & $\begin{array}{c}2.32 \\
(2.70)\end{array}$ \\
\hline $\begin{array}{l}\text { Livestock } \\
\text { owned } \\
\text { (number) }\end{array}$ & $\begin{array}{c}601.15 \\
(240.50)\end{array}$ & $\begin{array}{l}491.27^{* *} \\
(250.72)\end{array}$ & $\begin{array}{c}109.88^{* * *} \\
(40.65)\end{array}$ & $\begin{array}{c}37.87 * * \\
(18.0)\end{array}$ & $\begin{array}{c}22.50^{* * *} \\
(8.98)\end{array}$ \\
\hline $\begin{array}{l}\text { Model } \\
\text { intercept }\end{array}$ & $\begin{array}{c}15959.72^{* * *} \\
(2212.4)\end{array}$ & $\begin{array}{l}8503.94^{* * *} \\
(1997.33)\end{array}$ & $\begin{array}{c}7455.71^{* * *} \\
(777.22)\end{array}$ & $\begin{array}{c}3509.47^{* * *} \\
(322.31)\end{array}$ & $\begin{array}{c}1105.89^{* * *} \\
(180.53)\end{array}$ \\
\hline $\begin{array}{l}\text { Regency level } \\
\text { fixed effects } \\
\text { included }\end{array}$ & Yes & Yes & Yes & Yes & Yes \\
\hline $\begin{array}{l}\text { No. of } \\
\text { observation } \\
\text { s }\end{array}$ & 664 & 664 & 664 & 664 & 664 \\
\hline $\mathrm{F}$ & 9.81 & 6.66 & 7.13 & 6.07 & 5.49 \\
\hline Adj. $R^{2}$ & 0.25 & 0.19 & 0.20 & 0.16 & 0.15 \\
\hline
\end{tabular}

Notes: Standard errors are shown in parenthesis. Oil palm adoption only includes farmers cultivating productive oil palm plots. Area under oil palm and rubber only includes productive plots. Additional covariates used in the model are age, education level, ethnicity and migration background of the household head, household size, distance to the closest market place, village type and mode of village selection; ${ }^{*},{ }^{* *},{ }^{* *}$ indicate $10 \%, 5 \%$ and $1 \%$ level of significance testing that coefficients are equal to zero. 


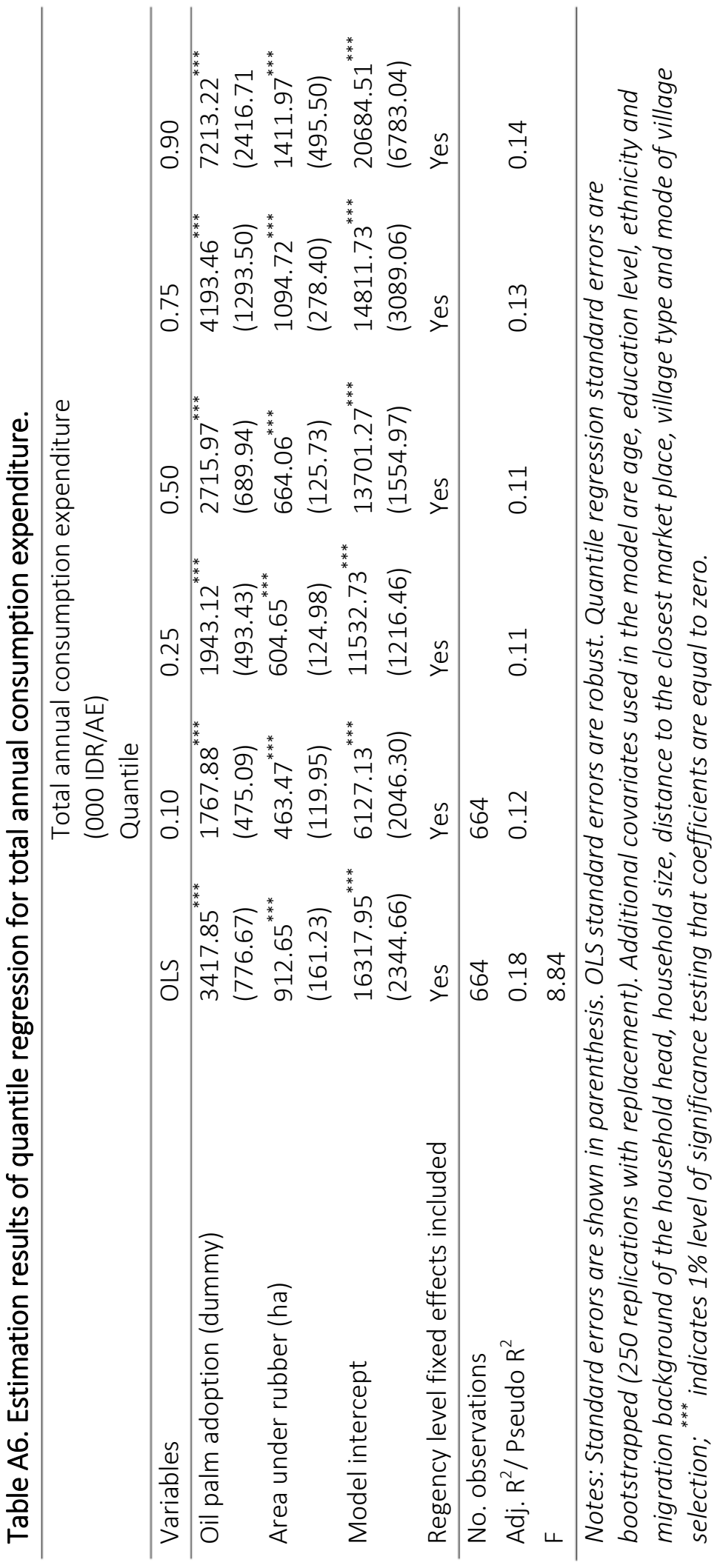




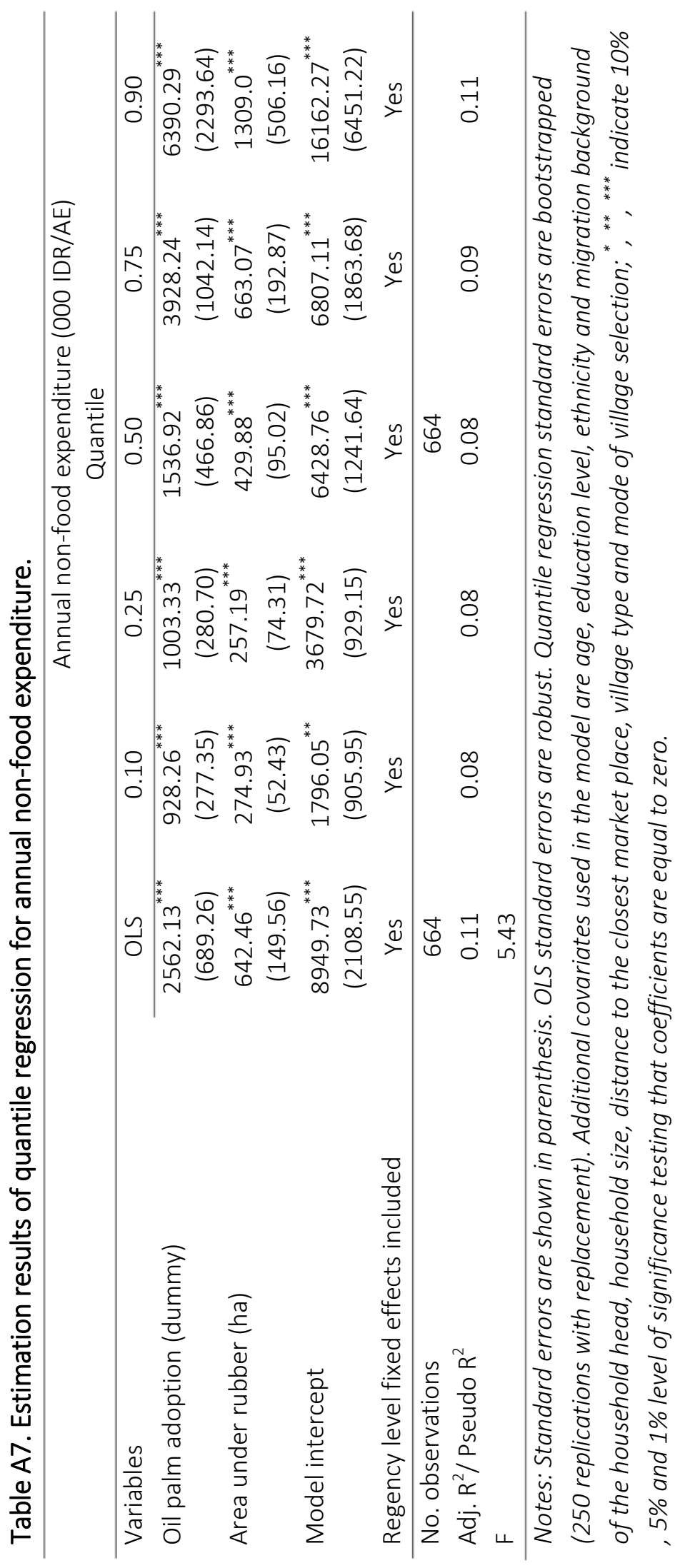




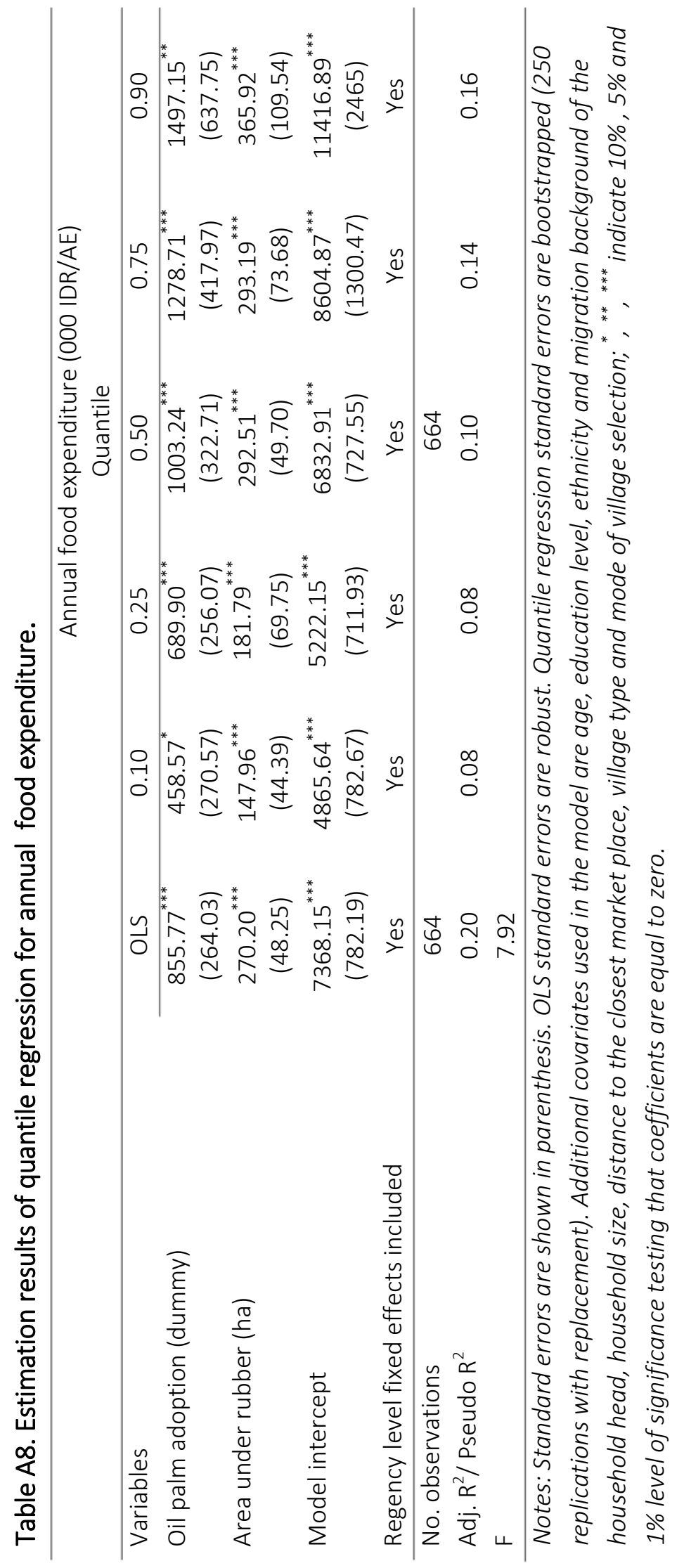




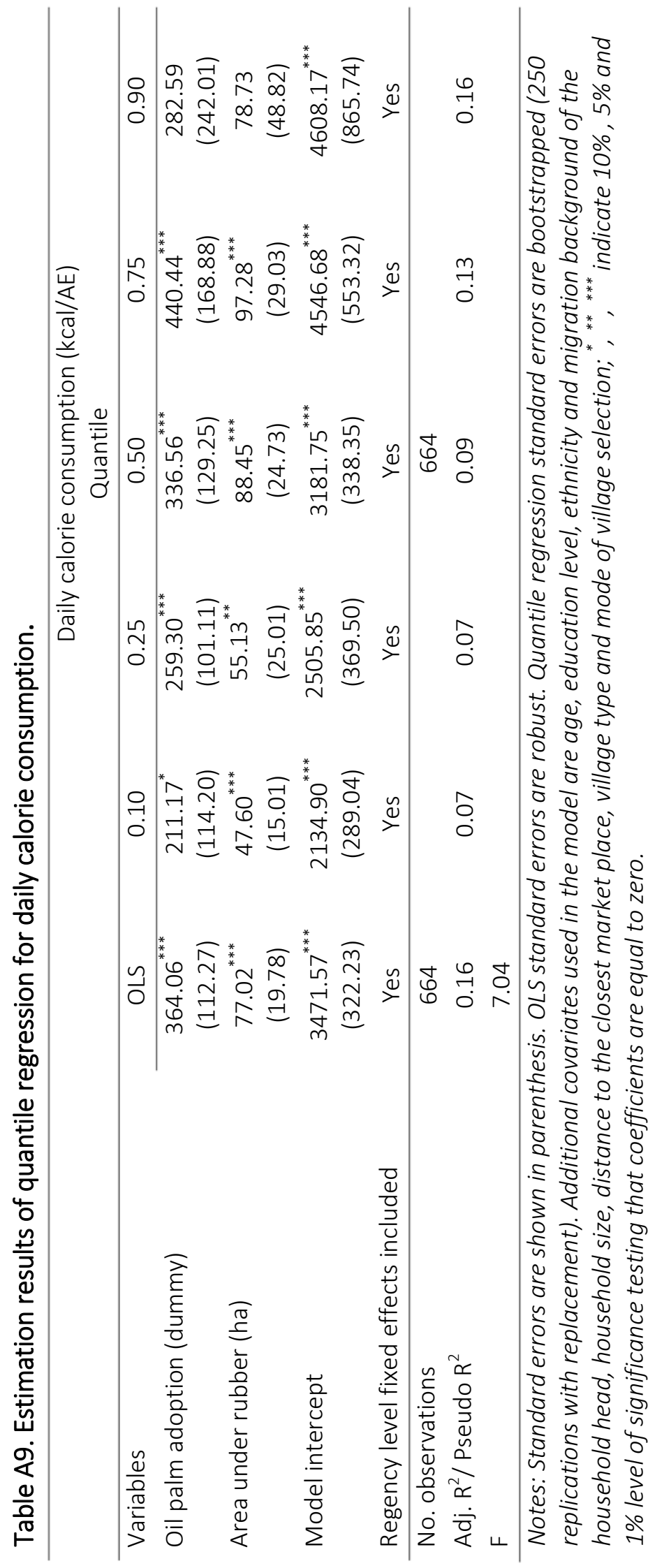




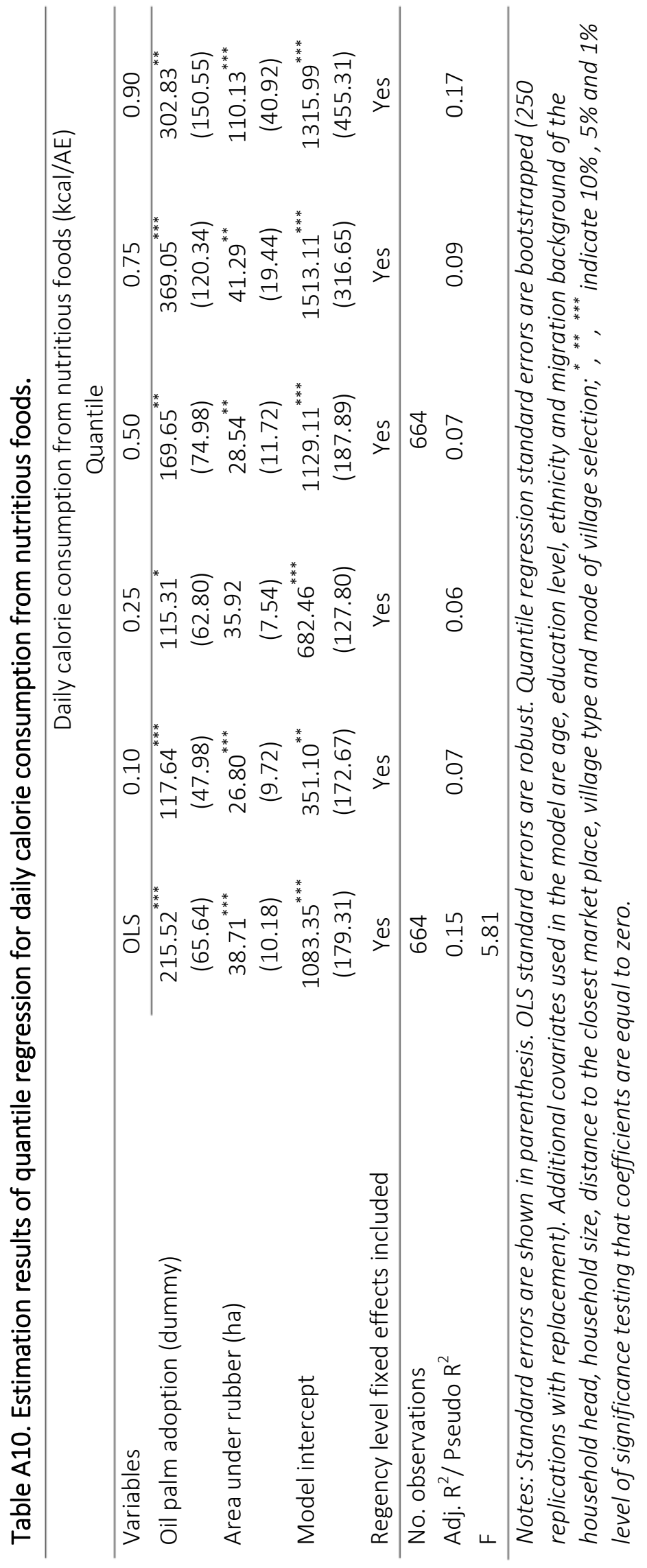




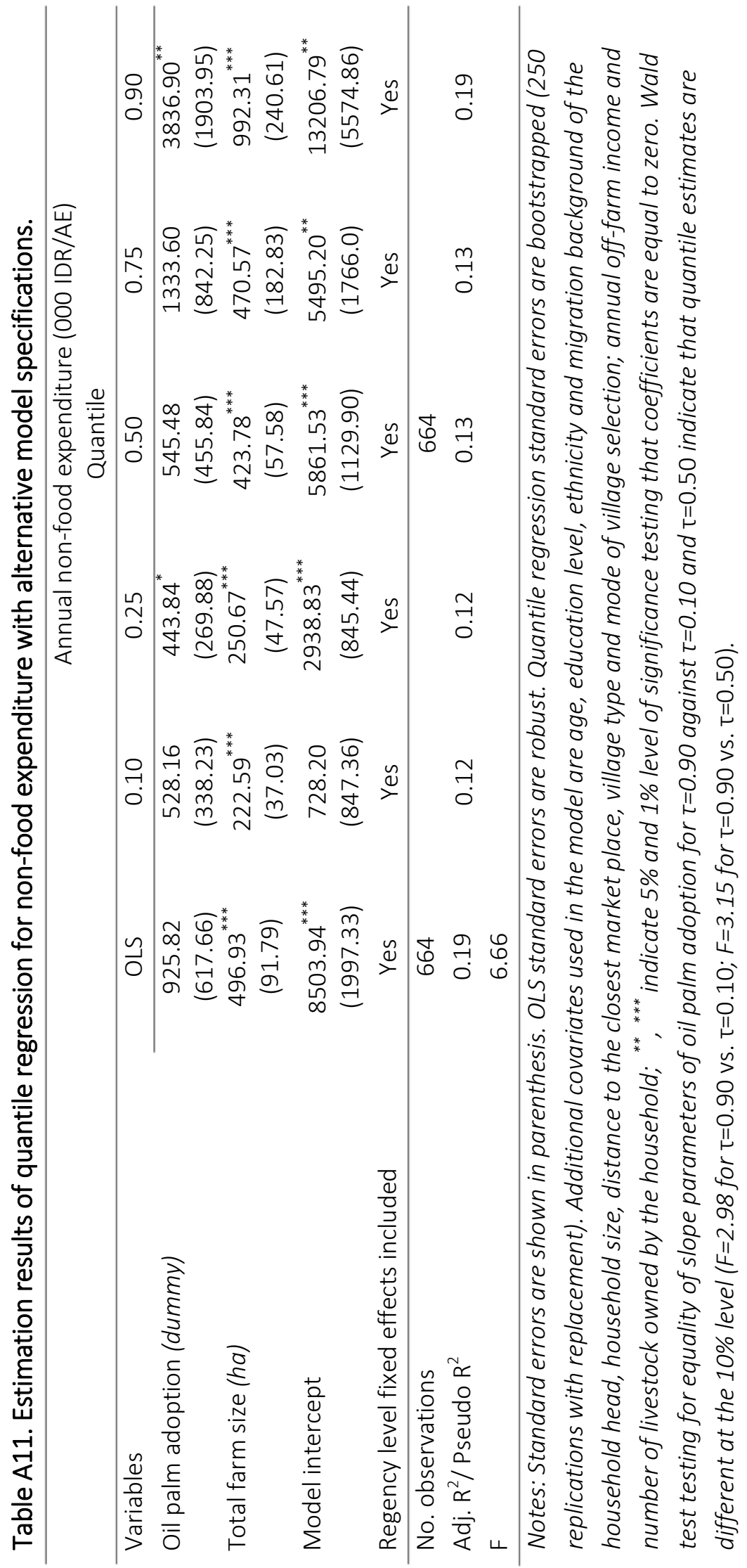




\section{APPENDIX B: HOUSEHOLD QUESTIONNAIRE}

\section{Household identification}

1. Village (name):

2. Dusun (name or number):

3. RT (number):

4. Household code (given by supervisor):

5. Full name of respondent:

6. Full name of head of household (only if he or she is not the respondent):

7. GPS co-ordinates of the household:

8. Mobile phone number:

9. Distance from the household's dwelling to the nearest market/trading center $(\mathrm{km})$

10.Interviewer (name):

11.Supervisor (name):

12. Date of interview

13. Date questionnaire was checked by supervisor:

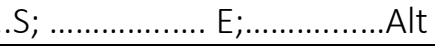

\section{General farm data}

\subsection{Cropping activities}

a. What kind of perennial crops are you currently growing on your farm

\begin{tabular}{|l|c|c|c|c|}
\hline Perennial crop type & $\begin{array}{c}\text { Area } \\
\text { under } \\
\text { cultivation } \\
\text { (ha) }\end{array}$ & $\begin{array}{c}\text { For how much of this } \\
\text { land (ha), you have }\end{array}$ & $\begin{array}{c}\text { Do you pay land } \\
\text { rent for this to } \\
\text { some one? }\end{array}$ \\
& & & $\begin{array}{c}\text { Land title? } \\
\text { from } \\
\text { village? }\end{array}$ & \\
\hline Oil palm (total) & & & & \\
\hline Oil palm (independent) & & & & Yes / No \\
\hline Oil palm (under contract) & & & & Yes / No \\
\hline Plantation rubber (total) & & & & Yes / No \\
\hline Plantation rubber (independent) & & & & Yes / No \\
\hline Plantation rubber (under contract) & & & & Yes / No \\
\hline Jungle Rubber & & & & Yes / No \\
\hline Acacia & & & & Yes / No \\
\hline Homestead and kitchen garden & & & & Yes / No \\
\hline Coconut & & & & Yes / No \\
\hline Any other crops (specify) & & & & Yes / No \\
\hline $\begin{array}{l}\text { Fallow land (no cultivation in last 12 } \\
\text { months) }\end{array}$ & & & & \multicolumn{2}{c}{} \\
\hline
\end{tabular}

b. Annuals cultivated in the farm during last 12 months 


\begin{tabular}{|c|c|c|c|c|c|c|c|}
\hline & \multirow[t]{2}{*}{$\begin{array}{l}\text { Crop } \\
\text { name }\end{array}$} & \multirow{2}{*}{$\begin{array}{l}\text { Area under } \\
\text { cultivation } \\
\text { (ha) }\end{array}$} & \multicolumn{2}{|c|}{$\begin{array}{l}\text { For how much of this } \\
\text { land (ha) you have }\end{array}$} & \multicolumn{2}{|c|}{$\begin{array}{l}\text { Week and month } \\
\text { (code) }\end{array}$} & \multirow{2}{*}{$\begin{array}{c}\text { Do you pay land } \\
\text { rent for this to } \\
\text { someone? }\end{array}$} \\
\hline & & & $\begin{array}{l}\text { Land } \\
\text { title? }\end{array}$ & $\begin{array}{c}\text { Certificate } \\
\text { from village? }\end{array}$ & Sowing & $\begin{array}{c}\text { Last } \\
\text { harvesting }\end{array}$ & \\
\hline \multirow{5}{*}{$\begin{array}{l}\text { Dry } \\
\text { season }\end{array}$} & & & & & & & Yes / No \\
\hline & & & & & & & Yes / No \\
\hline & & & & & & & Yes / No \\
\hline & & & & & & & Yes / No \\
\hline & & & & & & & Yes / No \\
\hline \multirow{6}{*}{$\begin{array}{l}\text { Rainy } \\
\text { season }\end{array}$} & & & & & & & Yes / No \\
\hline & & & & & & & Yes / No \\
\hline & & & & & & & Yes / No \\
\hline & & & & & & & Yes / No \\
\hline & & & & & & & Yes / No \\
\hline & & & & & & & Yes / No \\
\hline
\end{tabular}

Code: week/month. Week = 1, 2, 3, 4; January = 1; February = 2; March = 3; April = 4; May = 5; June = 6; July = 7; August $=8$; September $=9 ;$ October $=10 ;$ November $=11 ;$ December $=12$

\subsection{Land ownership}

\begin{tabular}{|c|c|c|}
\hline \multirow{3}{*}{$\begin{array}{l}\text { In the last } 12 \text { months, did you own any } \\
\text { land, which is cultivated by some other } \\
\text { household? }\end{array}$} & \multirow{3}{*}{ Yes/No } & If yes: \\
\hline & & Size of such land: :............ ha \\
\hline & & $\begin{array}{l}\text { Rent you got for renting out: Rp:................... } \\
\text { ‘000/ha/year. }\end{array}$ \\
\hline \multirow{3}{*}{$\begin{array}{l}\text { In the last } 12 \text { months, did you cultivate in } \\
\text { any land, owned by others? }\end{array}$} & \multirow[t]{3}{*}{ Yes/No } & If yes: \\
\hline & & Size of such land: :............ ha \\
\hline & & $\begin{array}{l}\text { Rent you paid for renting in: Rp:................... } \\
\text { '000/ha/year. }\end{array}$ \\
\hline \multirow{4}{*}{$\begin{array}{l}\text { In the last } 12 \text { months, did you cultivate any } \\
\text { land under any share cropping } \\
\text { arrangement with another farmer or group } \\
\text { of farmers (by sharing costs and return } \\
\text { from crop production)? }\end{array}$} & \multirow[t]{4}{*}{ Yes/No } & If yes, \\
\hline & & Total land under this arrangement:......... ha \\
\hline & & $\begin{array}{l}\text { How much of the land you own is under this } \\
\text { arrangement? .......... ha }\end{array}$ \\
\hline & & No. of farmers in the group: ............... \\
\hline
\end{tabular}

HH number: 


\section{History of perennial crop cultivation}

\subsection{Migration}

- Is the household migrated from somewhere to this village? ....... (Yes/No) (If no, go to 3.2).

- If yes, did the household migrate as part of transmigrant programme? (Yes/No)

- If yes, the crop associated with transmigrant programme: Oil palm/ Rubber/Others (specify):........ - Details of starting of cultivation and contract for transmigrant households

\begin{tabular}{|c|c|c|c|}
\hline 1 & \multicolumn{2}{|c|}{ When did the household migrate to the village? (Year) } & \\
\hline 2. & \multicolumn{2}{|c|}{ Who was the head of the household at the time of migration? (Code A) } & \\
\hline 3. & \multicolumn{2}{|c|}{$\begin{array}{l}\text { If you were not the head of household at time of migration, age of the } \\
\text { household head at that time (Years) }\end{array}$} & \\
\hline 4. & \multicolumn{2}{|c|}{ The place from where the household migrated to this village? (Code B) } & \\
\hline & \multicolumn{2}{|c|}{$\begin{array}{l}\text { What was the major source of income for the household before migration? } \\
\text { (Code C) }\end{array}$} & \\
\hline 6. & \multicolumn{2}{|c|}{$\begin{array}{l}\text { What was your household size before migration? (number of household } \\
\text { members) }\end{array}$} & \\
\hline & \multicolumn{2}{|c|}{ How many of your household members.... (number) } & \\
\hline & \multicolumn{2}{|c|}{ a. Came to this village in your group of migration? } & \\
\hline & \multicolumn{2}{|c|}{ b. Arrived in this village after you came? (exclude the members born here) } & \\
\hline 8. & \multicolumn{2}{|c|}{ How many other households ...(number) } & \\
\hline & \multicolumn{2}{|c|}{ a. Came to this village in your group of migration? } & \\
\hline & \multicolumn{2}{|c|}{ b. Were already living in this village when you arrived? } & \\
\hline & \multicolumn{2}{|c|}{ c. Arrived in this village after you came? } & \\
\hline & \multicolumn{2}{|c|}{ d. Came to this village as migrants (in total)? } & \\
\hline & \multicolumn{2}{|l|}{ e. Are there in this village now? } & \\
\hline 9. & \multicolumn{2}{|c|}{ Was there a house already built for you in this village (e.g. by the government)? } & Yes / No \\
\hline \multirow{3}{*}{\multicolumn{2}{|c|}{$\begin{array}{l}\text { 10. What was the size of land provided by } \\
\text { government as part of the transmigrant } \\
\text { programme? }\end{array}$}} & a. Plantation (ha) & \\
\hline & & b. Food crops (ha) & \\
\hline & & c. Housing $\left(\mathrm{m}^{2}\right)$ & \\
\hline
\end{tabular}

Code $\mathrm{A}$ : current $\mathrm{HH}$ head $=1$, father/mother of current $\mathrm{HH}$ head=2; grandparent of current $\mathrm{HH}$ head $=3$; brother/sister of current HH head=4; other (specify) $=5$; Code B: Other part of Jambi $=1$; Java $=2$; North Sumatra $=3$; South Sumatra $=4$; Kalimantan $=5$; Sulawesi $=6$; others ( specify) $=7$;

Code C: crops $=1$; fisheries and livestock $=2$; wage labour $=3$; small business $=4$; others (specify) $=5$ 
3.2. Household details at plantation start (Do not include the crop covered under transmigrant programme. But if a transmigrant household started another crop later, that information should be included in this table.).

\begin{tabular}{|c|c|c|c|}
\hline & Oil palm & $\begin{array}{l}\text { Plantation } \\
\text { rubber }\end{array}$ & $\begin{array}{l}\text { Jungle } \\
\text { rubber }\end{array}$ \\
\hline $\begin{array}{l}\text { 1. Have you ever cultivated the crop? (If no, please go to } \\
\text { next column) }\end{array}$ & Yes / No & Yes / No & Yes / No \\
\hline 2. When did the household start cultivating the crop? (Year) & & & \\
\hline $\begin{array}{l}\text { 3. Which of your family members first started the } \\
\text { cultivation/ obtained the plantation? (Code A) (If Code } \\
\text { A=1 go to question 5) }\end{array}$ & & & \\
\hline \multicolumn{4}{|l|}{$\begin{array}{l}\text { 4. If some other household member (and not the current } \\
\text { head) started the plantation, then: }\end{array}$} \\
\hline \multicolumn{4}{|l|}{$\begin{array}{l}\text { a. Relation of that member with the current household } \\
\text { head (Code B) }\end{array}$} \\
\hline \multicolumn{4}{|l|}{ b. Age of this member at starting of the estate (Years) } \\
\hline \multicolumn{4}{|l|}{$\begin{array}{l}\text { c. Gender of this household member (male }=0 \text {, female }= \\
\text { 1) }\end{array}$} \\
\hline \multicolumn{4}{|l|}{$\begin{array}{l}\text { d. Education of this member when the estate was started } \\
\text { (Years in school): }\end{array}$} \\
\hline e. Was he/she residing in this village for all his/her life? & Yes / No & Yes / No & Yes / No \\
\hline \multicolumn{4}{|l|}{ f. If no, when did he/she migrate to this village (Year) } \\
\hline $\begin{array}{l}\text { 5. Was the whole estate planted by the household? (If yes, } \\
\text { go to question 6) }\end{array}$ & Yes / No & Yes / No & Yes / No \\
\hline \multicolumn{4}{|l|}{$\begin{array}{l}\text { a. Size of the estate that was not established by } \\
\text { household (ha) }\end{array}$} \\
\hline \multicolumn{4}{|l|}{$\begin{array}{l}\text { b. Number of oil palm / rubber trees already existing in } \\
\text { that field }\end{array}$} \\
\hline \multicolumn{4}{|l|}{ c. What was the average age of trees? (years) } \\
\hline \multicolumn{4}{|l|}{ 6. Before the plantation was started, } \\
\hline \multicolumn{4}{|l|}{$\begin{array}{l}\text { a. How many adult family members were there in your } \\
\text { household (number)? }\end{array}$} \\
\hline \multicolumn{4}{|l|}{$\begin{array}{l}\text { b. How much land did your household have under } \\
\text { cultivation? (ha) }\end{array}$} \\
\hline \multicolumn{4}{|l|}{$\begin{array}{l}\text { c. For how much of this land did your household have a } \\
\text { land title? (ha) }\end{array}$} \\
\hline d. Were any of your relatives already cultivating the crop? & Yes / No & Yes / No & Yes / No \\
\hline \multicolumn{4}{|l|}{$\begin{array}{l}\text { e. How many of the other farmer households in your } \\
\text { neighborhood/RT started the cultivation before you? } \\
\text { (number) }\end{array}$} \\
\hline \multicolumn{4}{|l|}{$\begin{array}{l}\text { 7. Total number of households in the neighborhood/ RT at } \\
\text { that point of time? }\end{array}$} \\
\hline & $\begin{array}{l}\text { Please go } \\
\text { to next } \\
\text { column }\end{array}$ & $\begin{array}{l}\text { Please go to } \\
\text { next column }\end{array}$ & $\begin{array}{l}\text { Please go } \\
\text { to next } \\
\text { section }\end{array}$ \\
\hline
\end{tabular}

Code $\mathrm{A}$ : current $\mathrm{HH}$ head $=1$; previous $\mathrm{HH}$ head $=2$; acquired through marriage $=3$; others (specify) $=4$

Code $\mathrm{B}$ : father $/$ mother $=1$; grandparent $=2$; brother $=3$; in-laws $=4$; others (specify) $=5$ 


\subsection{Oil palm /Plantation Rubber /Jungle Rubber (fill once for each crop)}

- Have you ever cultivated oil palm /plantation rubber/jungle rubber?( $\mathrm{Y} / \mathrm{N}$ )

- With how many hectares did you start cultivation? ha

- How many hectares do you have today? ha

- How many times was the area under this crop changed from the start of cultivation until today?

\begin{tabular}{|c|c|c|c|c|c|c|}
\hline & & Start & $\begin{array}{c}\text { Change } \\
1\end{array}$ & $\begin{array}{c}\text { Ch. } \\
2\end{array}$ & $\begin{array}{c}\text { Ch. } \\
3\end{array}$ & $\begin{array}{c}\text { Ch. } \\
4\end{array}$ \\
\hline $\begin{array}{l}\text { 1. What was the } \\
\text { OR after the } \mathrm{ch}\end{array}$ & $\begin{array}{l}\text { ze of land under the crop at the beginning } \\
\text { ange (ha)? }\end{array}$ & & & & & \\
\hline 2. Nature of chan & e (E: expansion; R: reduction) & & & & & \\
\hline $\begin{array}{l}\text { 3. When did the } \\
\text { under the crop }\end{array}$ & $\begin{array}{l}\text { irmer start cultivating/ changed the area } \\
\text { (Year) }\end{array}$ & & & & & \\
\hline 4. How did this $\mathrm{cl}$ & ange in land area happened? (Code A) & & & & & \\
\hline a. If Code $A=1$ & Land area (ha) purchased/sold & & & & & \\
\hline or 2 & Land price paid/received ('000 Rp/ha) & & & & & \\
\hline $\begin{array}{l}\text { b. If Code } A=1 \mathrm{c} \\
\text { land when co }\end{array}$ & $\begin{array}{l}3 \text {, what crops/plants were there on the } \\
\text { verted? (Code B) }\end{array}$ & & & & & \\
\hline $\begin{array}{l}\text { c. If Code } A=6 \text {, } \\
\text { land when lar }\end{array}$ & $\begin{array}{l}\text { or } 8, \text { what crops/plants were there on the } \\
\text { was received? (Code B) }\end{array}$ & & & & & \\
\hline $\begin{array}{l}\text { d. If Code } A=7 \mathrm{c} \\
\text { your name? ( }\end{array}$ & $\begin{array}{l}\text { 8, which year did you got the land title in } \\
\text { A if not obtained so far). }\end{array}$ & & & & & \\
\hline $\begin{array}{l}\text { 5. Total plantatio } \\
\text { excluding the I } \\
\text { planting the se } \\
\end{array}$ & $\begin{array}{l}\text { establishment costs per ha ('000 Rp/ha; } \\
\text { nd price; only for clearing the land and } \\
\text { dlings) }\end{array}$ & & & & & \\
\hline $\begin{array}{l}\text { 6. How did you o } \\
\text { conversion cos } \\
\text { 7) }\end{array}$ & $\begin{array}{l}\text { Sanize the investment amount (land price }+ \\
\text { )? (Code C) (If Code C is not } 2 \text { go to question }\end{array}$ & & & & & \\
\hline a. $\quad$ Sourcess & of this credit? (Code D) & & & & & \\
\hline Amount & f credit ('000 Rp) & & & & & \\
\hline (Prescrib & d) duration of the credit (months) & & & & & \\
\hline Interest & ate (\% annual) & & & & & \\
\hline Repayme & ht completed? (Yes/No) & & & & & \\
\hline f. Year of $\mathrm{l}$ & t payment & & & & & \\
\hline In case of reductio & of land area & & & & & \\
\hline 7. Why was plant & tion size reduced? (Code E) & & & & & \\
\hline a. If Code $E=4$, & as there a conflict associated? & & $\mathrm{Y} / \mathrm{N}$ & $\mathrm{Y} / \mathrm{N}$ & $\mathrm{Y} / \mathrm{N}$ & $\mathrm{Y} / \mathrm{N}$ \\
\hline $\begin{array}{l}\text { b. If Code } \mathrm{E}=3 \text {, } \\
\text { obtained ('00 }\end{array}$ & $\begin{array}{l}\text { what was the total amount compensation } \\
\text { Rp) }\end{array}$ & & & & & \\
\hline
\end{tabular}

Code A: purchasing = 1 ; selling $=2$; converted from/to other crops $=3$; conversion from forest $=4$; obtained as part of a government programme (e.g."transmigransi") $=5$; established plantation obtained from company $=6$; inherited $=7$; received as gift $=8$; others (specify) $=9$

Code B: oil palm $=1$; plantation rubber $=2$; jungle rubber $=3$; other plantation $=4$; annual crops (specify) $=5$; grassland $=6$; forest $=7$; bush $=8$; others ( (pecify) $=9$

Code C: savings $=1 ;$ credit $=2 ;$ parents $/$ spouse $=3 ;$ no need to pay at the beginning $=4$; others (specify) $=5$ Code D: banks $=1$; private company $=2$; money lender $=3$; friends $/$ relatives $=4$; farmer cooperative $=5$; other farmers $=6$; others (specify) $=7$

Code $\mathrm{E}$ : land sold $=1$; land contracted out to other family = 2; land submitted to a company $=3$; land lost without compensation $=4$; land given away to other family member or relative $=5$; other (specify) $=6$ 
3.4. Information and institutional context of smallholder plantation

\begin{tabular}{|l|c|c|c|}
\hline & $\begin{array}{c}\text { Oil palm } \\
\text { (if never, go to } \\
\text { next column) }\end{array}$ & $\begin{array}{c}\text { Plantation Rubber } \\
\text { (if never, next } \\
\text { column) }\end{array}$ & $\begin{array}{c}\text { Jungle rubber } \\
\text { (if never, go to } \\
\text { next section) }\end{array}$ \\
\hline Before starting your own plantation: & & & Yes/ No \\
\hline $\begin{array}{l}\text { 1. Have you ever worked on that crop? (If } \\
\text { no go to question 2) }\end{array}$ & Yes/ No & & \\
\hline a. If yes, how or in what context? (Code A) & & & \\
\hline b. For how long? (number of years) & & & Yes/ No \\
\hline $\begin{array}{l}\text { c. From which year have you started this } \\
\text { work? (year) }\end{array}$ & & Yes/ No & Yes/ No \\
\hline At the time of starting your own plantation & & & \\
\hline $\begin{array}{l}\text { 2. Were you participating in any village level } \\
\text { cooperatives/ farmer groups? }\end{array}$ & Yes/ No & Yes/ No & \\
\hline $\begin{array}{l}\text { a. If yes, type of groups (Code B) } \\
\text { 3. Did you have access to technical support } \\
\text { at this time? }\end{array}$ & Yes/ No & & \\
\hline \begin{tabular}{l} 
a. If yes, offered by whom? (Code C) \\
\hline
\end{tabular}
\end{tabular}

Code A: as labour = 1; share-cropping = 2; trader=3; with family = 4; others $=5$ (specify); Code B: farmer group = 1 ; cooperative society $=2$; others $=3$ ( specify); Code C: plantation company $=1$; government extension $=2$; cooperative/farmer group $=3$; others $=4$ ( ppecify)

3.5. Sources of inputs if purchased during the last 12 months for the entire farm (that is for all crops being cultivated by farmer, annuals and perennials)

\begin{tabular}{|c|c|c|c|c|c|c|c|c|}
\hline & \multicolumn{2}{|c|}{$\begin{array}{l}\text { Seedlings } \\
\text { oil palm }\end{array}$} & \multicolumn{2}{|c|}{$\begin{array}{l}\text { Seedlings } \\
\text { rubber }\end{array}$} & \multicolumn{2}{|c|}{$\begin{array}{l}\text { Chemical } \\
\text { fertilizers }\end{array}$} & \multicolumn{2}{|c|}{$\begin{array}{l}\text { Herbicides and } \\
\text { pesticides }\end{array}$} \\
\hline $\begin{array}{l}\text { Purchased/ } \\
\text { obtained } \\
\text { these } \\
\text { inputs? }\end{array}$ & \multicolumn{2}{|c|}{$\begin{array}{l}\text { Yes/No } \\
\text { (If no, go to next } \\
\text { column })\end{array}$} & \multicolumn{2}{|c|}{$\begin{array}{l}\text { Yes/No } \\
\text { (If no, go to next } \\
\text { column) }\end{array}$} & \multicolumn{2}{|c|}{$\begin{array}{l}\text { Yes/No } \\
\text { (If no, go to next } \\
\text { column) }\end{array}$} & \multicolumn{2}{|c|}{$\begin{array}{l}\text { Yes/No } \\
\text { (If no, go to next } \\
\text { section) }\end{array}$} \\
\hline \multirow[t]{2}{*}{$\begin{array}{l}\text { If yes, } \\
\text { from how } \\
\text { many } \\
\text { sources? }\end{array}$} & & & & & & & & \\
\hline & $\begin{array}{l}\text { Primary } \\
\text { source }\end{array}$ & $\begin{array}{l}\text { Secondary } \\
\text { source* }\end{array}$ & $\begin{array}{l}\text { Primary } \\
\text { source }\end{array}$ & $\begin{array}{l}\text { Secondary } \\
\text { source* }\end{array}$ & $\begin{array}{l}\text { Primary } \\
\text { source }\end{array}$ & $\begin{array}{l}\text { Secondary } \\
\text { source* }\end{array}$ & $\begin{array}{l}\text { Primary } \\
\text { source }\end{array}$ & $\begin{array}{c}\text { Secondary } \\
\text { source* }\end{array}$ \\
\hline \multicolumn{9}{|l|}{$\begin{array}{l}\text { Source } \\
\text { type (code) }\end{array}$} \\
\hline \multicolumn{9}{|l|}{$\begin{array}{l}\text { Share of } \\
\text { purchase }\end{array}$} \\
\hline $\begin{array}{l}\text { Obtained } \\
\text { subsidized } \\
\text { inputs? }\end{array}$ & Yes/No & Yes/No & Yes/No & Yes/No & Yes/No & Yes/No & Yes/No & Yes/No \\
\hline $\begin{array}{l}\text { Input } \\
\text { credit } \\
\text { available }\end{array}$ & Yes/No & Yes/No & Yes/No & Yes/No & Yes/No & Yes/No & Yes/No & Yes/No \\
\hline \multicolumn{9}{|l|}{$\begin{array}{l}\text { Distance } \\
\text { from farm } \\
(\mathrm{km})\end{array}$} \\
\hline $\begin{array}{l}\text { Inputs at } \\
\text { farm gate? }\end{array}$ & Yes/No & Yes/No & Yes/No & Yes/No & Yes/No & Yes/No & Yes/No & Yes/No \\
\hline
\end{tabular}

Code: estate company or contractor $=1$; official dealer $=2$; unofficial dealer $=3$; farmer group $/$ cooperative society $=4$; output trader $=5$; government outlets $=6$; others $=7$ (specify)

HH number: 
4. Plantation crops: Plot endowment, contract arrangements and production relations

4.1. General plot information [A plot is defined as a piece of land under one crop, which is not segmented spatially and where the managerial practices are common and palms/trees are of approximately same age. Complete one column before going to next.]. How many plots do you have?.

\begin{tabular}{|c|c|c|c|c|}
\hline Plot ID & Plot 1 & Plot 2 & Plot 3 & Plot 4 \\
\hline \multicolumn{5}{|l|}{ 1. Area of plot (ha) } \\
\hline \multicolumn{5}{|l|}{ 2. Number of palms/trees in the plot } \\
\hline 3. Ownership of land: Owned/Leased-in & Own/Lsd-in & Own/Lsd-in & $\begin{array}{l}\text { Own/Lsd- } \\
\text { in }\end{array}$ & $\begin{array}{l}\text { Own/Lsd- } \\
\text { in }\end{array}$ \\
\hline 4. Sharecropping? (If no go to question 5) & Yes/No & Yes/No & Yes/No & Yes/No \\
\hline \multicolumn{5}{|l|}{ a. If yes, how many of farmers involved? (number) } \\
\hline \multicolumn{5}{|l|}{ b. Input cost (\%) shared by the household } \\
\hline \multicolumn{5}{|l|}{ c. Labour cost (\%) shared by the household } \\
\hline \multicolumn{5}{|l|}{ d. Output revenue (\%) shared by the household } \\
\hline \multicolumn{5}{|l|}{ 5. Who is currently managing the plot? (Code A) (If Code $A$ is not 2 or 3 go to question 7) } \\
\hline \multicolumn{5}{|l|}{ 6. If entrusted someone else (e.g. plantation company, other farmer etc.): } \\
\hline \multicolumn{5}{|l|}{ a. Monthly costs paid by household ('000 Rp.) } \\
\hline \multicolumn{5}{|l|}{ b. Monthly revenues obtained by household ('000 Rp.) } \\
\hline $\begin{array}{l}\text { 7. Is there is a land title (certificate) for this land in your (or some other household } \\
\text { member's) name, at present? (If no go to question 9) }\end{array}$ & Title/ Certificate/ None & $\mathrm{T} / \mathrm{C} / \mathrm{N}$ & $\mathrm{T} / \mathrm{C} / \mathrm{N}$ & $\mathrm{T} / \mathrm{C} / \mathrm{N}$ \\
\hline $\begin{array}{l}\text { 8. If there is a land title or certificate in HH head's name, do you have it with you at } \\
\text { present (and not with other person/ institution, e.g. a credit institution)? }\end{array}$ & Yes/No/NA & Yes/No/NA & $\begin{array}{l}\text { Yes/No/N } \\
\text { A }\end{array}$ & Yes/No/NA \\
\hline $\begin{array}{l}\text { 9. Was this plot self-established (that is, the household did not obtain an estate } \\
\text { established by someone else)? (If no go to question 11) }\end{array}$ & Yes/No & Yes/No & Yes/No & Yes/No \\
\hline \multicolumn{5}{|l|}{ 10. In case of self-establishment; year of establishment? } \\
\hline \multicolumn{5}{|l|}{$\begin{array}{l}\text { 11. In case plot was not established by the household, how did you acquire the plot? } \\
\text { (Code B) }\end{array}$} \\
\hline \multicolumn{5}{|l|}{ 12. If at least part of the estate was not established by the household } \\
\hline a. $\quad$ Year of procurement/purchase & & & & \\
\hline b. Number of palms/trees already existing in the plot & & & & \\
\hline c. Age of palms/trees at the time of procurement & & & & \\
\hline
\end{tabular}

Code A: household = 1; entrusted to company $=2$; entrusted to farmer cooperative $=3$; other farmer $=4$; others $=5$ (specify); Code $\mathbf{B}$ : transmigrant programme = 1; other government programme $=2$; purchased from other farmers $=3$; inherited $=4$; converted from forest (no purchase) $=5$; others $($ specify) $=6$

HH number: 
4.1. Contd.

\begin{tabular}{|c|c|c|c|c|}
\hline Plot ID & Plot 1 & Plot 2 & Plot 3 & Plot 4 \\
\hline \multicolumn{5}{|l|}{ 14. Year of last replanting in the plot (put NA if never replanted). } \\
\hline \multicolumn{5}{|l|}{$\begin{array}{l}\text { 16. Varieties grown (names; put } N I \text { if he has no information on the variety } \\
\text { names) }\end{array}$} \\
\hline \multicolumn{5}{|l|}{ 17. Number of palms/trees of variety per plot (at the time of survey) } \\
\hline a. variety 1: name of variety and number of palms or trees per plot & Name \& Number & $\begin{array}{l}\text { Name \& } \\
\text { Number }\end{array}$ & $\begin{array}{l}\text { Name \& } \\
\text { Number }\end{array}$ & $\begin{array}{l}\text { Name \& } \\
\text { Number }\end{array}$ \\
\hline b. variety 2: name of variety and number of palms or trees per plot & Name \& Number & $\begin{array}{l}\text { Name \& } \\
\text { Number }\end{array}$ & $\begin{array}{l}\text { Name \& } \\
\text { Number }\end{array}$ & $\begin{array}{l}\text { Name \& } \\
\text { Number }\end{array}$ \\
\hline 19. Have you ever used fire for land clearing in this plot? & Yes/ No & Yes/ No & Yes/ No & Yes/ No \\
\hline \multicolumn{5}{|l|}{ a. If yes, year of land clearing using fire } \\
\hline 20. Do you keep the cut-off plants and crop residues on the plot? & Yes/ No & Yes/No & Yes/No & Yes/No \\
\hline a. If yes, do you distribute these residues or pile them in a spot? & Distribute/Pile & Distribute/Pile & Distribute/Pile & Distribute/Pile \\
\hline \multicolumn{5}{|l|}{ 21. Distance from the plot to } \\
\hline a. home (meters) & & & & \\
\hline b. nearest road (meters) & & & & \\
\hline c. nearest forest area (meters) & & & & \\
\hline
\end{tabular}

HH number: 


\subsection{Contract details}

- Has the crop ever been cultivated under a contract arrangement?. (Yes/No) If no, please go to next section (4.3).

- Do you have a contract with more than one contract partners?. (Yes/No)

- If yes, with how many different contract partners did you sign a contract? (number)

\begin{tabular}{|c|c|c|c|}
\hline & \multicolumn{2}{|c|}{$\begin{array}{l}\text { Contract type (fill both columns if more } \\
\text { than one contract types prevails for a } \\
\text { single crop) }\end{array}$} \\
\hline & & Type 1 & Type 2 \\
\hline \multicolumn{2}{|c|}{$\begin{array}{l}\text { 1. Give the plot numbers (from 4.1.; multiple options } \\
\text { possible) to which this contract type referring to }\end{array}$} & & \\
\hline \multicolumn{2}{|c|}{ 2. Year of start of contract } & & \\
\hline \multicolumn{2}{|c|}{ 3. Year of start of the repayment } & & \\
\hline \multicolumn{2}{|c|}{$\begin{array}{l}\text { 4. Year of payment of last installment (indicate NC if } \\
\text { payment is ongoing at present) }\end{array}$} & & \\
\hline \multicolumn{2}{|c|}{$\begin{array}{l}\text { 5. Year you obtained the land title or certificate (indicate } \\
\text { NA if certificate not available as of now) }\end{array}$} & & \\
\hline \multicolumn{2}{|c|}{ 6. Who gave the land to start the plantation? (Code A) } & & \\
\hline \multicolumn{2}{|c|}{ 7. Who established the plantation? (Code A) } & & \\
\hline \multicolumn{2}{|c|}{$\begin{array}{l}\text { 8. What was the land price (with established plantation) in } \\
\text { this locality at the time of starting the contract ('000 } \\
\mathrm{Rp} / \mathrm{ha} \text { ) }\end{array}$} & & \\
\hline \multicolumn{2}{|c|}{ 9. Who took initiative to start the contract arrangement? } & $\begin{array}{l}\text { You/ Company/ } \\
\text { Govt. }\end{array}$ & $\begin{array}{l}\text { You/ Company/ } \\
\text { Govt. }\end{array}$ \\
\hline \multicolumn{2}{|c|}{$\begin{array}{l}\text { 10. What is the name of the company you are contracted } \\
\text { under? }\end{array}$} & & \\
\hline \multicolumn{2}{|c|}{ 11. Type of company } & private/gov & private/gov \\
\hline \multicolumn{4}{|c|}{$\begin{array}{l}\text { 12. Size of inti when they started contract (ha; put NI if you } \\
\text { have no information) }\end{array}$} \\
\hline \multicolumn{4}{|c|}{$\begin{array}{l}\text { 13. Size of plasma when they started contract (ha; put NI if } \\
\text { you have no information) }\end{array}$} \\
\hline \multicolumn{4}{|c|}{$\begin{array}{l}\text { 14. In total, how many farmers of your village had a } \\
\text { contract with your contract partner when the contract } \\
\text { was signed? (number) }\end{array}$} \\
\hline \multicolumn{2}{|c|}{$\begin{array}{l}\text { 15. When you negotiated the contract, were the farmers } \\
\text { organized in to a farmer cooperative/farmer group? (If } \\
\text { no go to question 17) }\end{array}$} & Yes/No & Yes/ No \\
\hline \multicolumn{4}{|c|}{ 16. If yes, } \\
\hline \multicolumn{4}{|c|}{$\begin{array}{l}\text { a. how many farmers were members in this } \\
\text { cooperative when you negotiated the contract? }\end{array}$} \\
\hline b. does this farmer coc & rative exist today? & Yes/No & Yes/No \\
\hline \multicolumn{4}{|c|}{ 17. How far is your plot from the inti area? $(\mathrm{km})$} \\
\hline \multicolumn{4}{|c|}{$\begin{array}{l}\text { 18. If you gave land to the company in the beginning of } \\
\text { contract, size of the land given by you (ha) }\end{array}$} \\
\hline \multirow{2}{*}{$\begin{array}{l}\text { 19. Size of land provided to } \\
\text { you by the company or }\end{array}$} & a. Plantation (ha) & & \\
\hline & b. Food crop (ha) & & \\
\hline
\end{tabular}

HH number: 


\begin{tabular}{|c|c|c|c|c|}
\hline & \multicolumn{2}{|c|}{$\begin{array}{l}\text { Contract type (fill both columns if more } \\
\text { than one contract types prevails for a } \\
\text { single crop) }\end{array}$} \\
\hline & & & Type 1 & Type 2 \\
\hline & government for: & c. Housing $\left(\mathrm{m}^{2}\right)$ & & \\
\hline \multicolumn{3}{|c|}{$\begin{array}{l}\text { 20. Who is currently holding the land title/certificate of your } \\
\text { plasma plantation? }\end{array}$} & $\begin{array}{l}\text { household/ } \\
\text { company/bank }\end{array}$ & $\begin{array}{l}\text { household / } \\
\text { company/ bank }\end{array}$ \\
\hline \multicolumn{3}{|c|}{$\begin{array}{l}\text { 21. What way the debt is being/was repaid to the company } \\
\text { (Code B) }\end{array}$} & & \\
\hline \multicolumn{5}{|c|}{ 22. If Code $B=1$ or 2} \\
\hline \multicolumn{3}{|c|}{$\begin{array}{l}\text { a. Number of times the payment had to be done } \\
\text { (according to contract) }\end{array}$} & & \\
\hline \multicolumn{3}{|c|}{ b. Number of times you have made payment } & & \\
\hline \multicolumn{3}{|c|}{$\begin{array}{l}\text { c. Prescribed payment at a time (according to } \\
\text { contract) ('000 Rp) }\end{array}$} & & \\
\hline \multicolumn{3}{|c|}{ d. Average payment you have made at a time ('000 Rp) } & & \\
\hline \multicolumn{5}{|c|}{ 23. If Code $B=3$ or 4} \\
\hline \multicolumn{3}{|c|}{$\begin{array}{l}\text { a. Under the contract, number of years the sales had } \\
\text { to be done }\end{array}$} & & \\
\hline \multicolumn{3}{|c|}{$\begin{array}{l}\text { b. Number of years you have actually sold to the } \\
\text { company }\end{array}$} & & \\
\hline \multicolumn{3}{|c|}{$\begin{array}{l}\text { c. During the contract time, did you actually sell your } \\
\text { products to other traders (at least sometimes)? }\end{array}$} & & \\
\hline \multicolumn{3}{|c|}{ d. \% of price reduction on average per harvest } & & \\
\hline \multicolumn{3}{|c|}{$\begin{array}{l}\text { e. \% share of harvest taken by company on average } \\
\text { per harvest }\end{array}$} & & \\
\hline \multicolumn{3}{|c|}{ f. Total quantity $(\mathrm{kg})$ of output sold at a time } & & \\
\hline \multicolumn{3}{|c|}{$\begin{array}{l}\text { 24. Under the contract, is the company supposed to provide } \\
\text { any input subsidies? }\end{array}$} & Yes/No & Yes/ No \\
\hline \multicolumn{3}{|c|}{$\begin{array}{l}\text { 25. In reality, are there any input subsidies ever available } \\
\text { from the company? (If no go to question 29) }\end{array}$} & Yes/No & Yes/ No \\
\hline \multirow{3}{*}{\multicolumn{2}{|c|}{ 26. Chemical fertilizer }} & $\begin{array}{l}\text { a. Amount provided per } \\
\text { year }(\mathrm{kg})\end{array}$ & & \\
\hline & & $\begin{array}{l}\text { b. Number of years this } \\
\text { subsidy was provided }\end{array}$ & & \\
\hline & & $\begin{array}{l}\text { c. } \text { Price discount (\% } \\
\text { reduction from market } \\
\text { price) }\end{array}$ & & \\
\hline \multirow{3}{*}{\multicolumn{2}{|c|}{ 27. Pesticides and herbicides }} & $\begin{array}{l}\text { a. Amount provided per } \\
\text { year }(\mathrm{kg})\end{array}$ & & \\
\hline & & $\begin{array}{l}\text { b. Number of years this } \\
\text { subsidy was provided }\end{array}$ & & \\
\hline & & $\begin{array}{l}\text { c. Price discount (\% } \\
\text { reduction from market } \\
\text { price) }\end{array}$ & & \\
\hline 28. & Others (specify) & $\begin{array}{l}\text { a. Amount of other input } \\
\text { (name) }\end{array}$ & & \\
\hline
\end{tabular}

HH number: 


\begin{tabular}{|c|c|c|c|}
\hline & \multicolumn{2}{|c|}{$\begin{array}{l}\text { Contract type (fill both columns if more } \\
\text { than one contract types prevails for a } \\
\text { single crop) }\end{array}$} \\
\hline & & Type 1 & Type 2 \\
\hline & provided per year & & \\
\hline & $\begin{array}{l}\text { b. Number of years this } \\
\text { subsidy was provided }\end{array}$ & & \\
\hline & $\begin{array}{l}\text { c. } \text { Price discount (\% } \\
\text { reduction from market } \\
\text { price) }\end{array}$ & & \\
\hline \multicolumn{2}{|c|}{$\begin{array}{l}\text { 29. Under the contract, is the company supposed to provide } \\
\text { you with information on crop production/extension } \\
\text { services? }\end{array}$} & Yes/No & Yes/ No \\
\hline \multicolumn{2}{|c|}{$\begin{array}{l}\text { 30. In reality, does the company offer any information on } \\
\text { crop production/ extension services? }\end{array}$} & Yes/No & Yes/ No \\
\hline \multicolumn{2}{|c|}{$\begin{array}{l}\text { 31. Under the contract, is the company supposed to offer } \\
\text { you employment in the inti/ processing plant? }\end{array}$} & Yes/No & Yes/ No \\
\hline \multicolumn{2}{|c|}{$\begin{array}{l}\text { 32. In reality, does the contract partner offer employment } \\
\text { for you in the inti/processing plant? }\end{array}$} & Yes/No & Yes/ No \\
\hline \multicolumn{2}{|c|}{$\begin{array}{l}\text { 33. Have you or any household member ever worked with } \\
\text { the company? (If no go to question 34) }\end{array}$} & Yes/No & Yes/ No \\
\hline \multicolumn{4}{|c|}{ a. If yes, for how long? (years) } \\
\hline \multicolumn{4}{|c|}{ b. If yes, average monthly salary obtained ('000 Rp.) } \\
\hline \multicolumn{2}{|c|}{$\begin{array}{l}\text { c. Number of household members currently working } \\
\text { with company }\end{array}$} & & \\
\hline \multicolumn{2}{|c|}{$\begin{array}{l}\text { 34. Under the contract, was/is the company supposed to } \\
\text { buy all your harvest? }\end{array}$} & Yes/No & Yes/ No \\
\hline \multicolumn{2}{|c|}{$\begin{array}{l}\text { 35. In reality, was the contract partner buying all your } \\
\text { harvest? }\end{array}$} & Yes/No & Yes/ No \\
\hline \multicolumn{2}{|c|}{$\begin{array}{l}\text { 36. Under the contract, how are prices are determined? } \\
\text { (Code C) }\end{array}$} & & \\
\hline \multicolumn{2}{|c|}{ - If Code C=1 prices fixed for how long? (weeks) } & & \\
\hline \multicolumn{2}{|c|}{ 37. Under the contract, does the company grant you credit? } & Yes/No & Yes/No \\
\hline
\end{tabular}

Code A: the household $=1$; plantation company $=2$; government $=3$; village $=4$; others $=5$ (specify); Code $\mathbf{B}$ : monthly repayment in cash $=1$; annual repayment in cash $=2$; reduction of price at sale of output $=3$; reduction of output quantity at sale $=4$; others $=5$ (specify); Code $C$ : prices are fixed by the company $=1$; prices according to local market price $=2$; other $($ specify $)=3$.

HH number: 
4.3. Intercropping arrangements in last 12 months

a. Annual crops

\begin{tabular}{|l|c|c|c|c|}
\hline \multirow{2}{*}{ Crop name } & \multicolumn{4}{|c|}{ Area under intercropping (ha) } \\
\cline { 2 - 5 } & Plot 1 & Plot 2 & Plot 3 & Plot 4 \\
\hline & & & & \\
\hline & & & & \\
\hline & & & & \\
\hline
\end{tabular}

b. Trees or perennial crops

\begin{tabular}{|l|c|c|c|c|}
\hline \multirow{2}{*}{ Tree name } & \multicolumn{4}{|c|}{ Number of trees in the plot } \\
\cline { 2 - 5 } & Plot 1 & Plot 2 & Plot 3 & Plot 4 \\
\hline & & & & \\
\hline & & & & \\
\hline & & & & \\
\hline
\end{tabular}

4.4. Inputs for plantation

\begin{tabular}{|c|c|c|c|c|}
\hline & Plot 1 & Plot 2 & Plot 3 & $\begin{array}{c}\text { Plot } \\
4\end{array}$ \\
\hline \multicolumn{5}{|l|}{ 1. Soil fertility $($ High $=2 ;$ Medium $=1$; Low $=0)$} \\
\hline 2. Provision of irrigation in the plot? & $\mathrm{Y} / \mathrm{N}$ & $\mathrm{Y} / \mathrm{N}$ & $\mathrm{Y} / \mathrm{N}$ & $\mathrm{Y} / \mathrm{N}$ \\
\hline \multicolumn{5}{|l|}{ 3. If yes, source(s) of irrigation: (Code) } \\
\hline \multirow{5}{*}{$\begin{array}{l}\text { 4. Are the plots similar to each other with respect } \\
\text { to? }\end{array}$} & \multicolumn{3}{|c|}{ a. Soil type or land type } & Yes / No \\
\hline & \multicolumn{2}{|c|}{ b. Age of trees } & \multicolumn{2}{|r|}{ Yes / No } \\
\hline & \multicolumn{2}{|c|}{ c. Contract types } & \multicolumn{2}{|r|}{ Yes / No } \\
\hline & \multicolumn{3}{|c|}{ d. Cultivation practices } & Yes / No \\
\hline & \multicolumn{3}{|c|}{ e. Others (specify) } & Yes / No \\
\hline \multicolumn{5}{|l|}{$\begin{array}{l}\text { 5. If there are similar plots, group them using " }+ \text { " } \\
\text { sign (e.g. } 1+2)\end{array}$} \\
\hline
\end{tabular}

Code: Tube-well $=1 ;$ Open well $=2 ;$ River $=3 ;$ Tank $=4 ;$ Others ( specify $)=5$.

HH number: 
4.4.1. Input use during last 12 months

\begin{tabular}{|c|c|c|c|c|c|c|c|c|c|}
\hline \multirow[t]{3}{*}{ Input } & \multirow{3}{*}{$\begin{array}{l}\text { Number of } \\
\text { times used in } \\
\text { last } 12 \text { months }\end{array}$} & \multirow{3}{*}{$\begin{array}{l}\text { Name } \\
\text { of input }\end{array}$} & \multirow{3}{*}{$\begin{array}{c}\text { Unit of } \\
\text { measurement } \\
\text { (QU) }\end{array}$} & \multirow{3}{*}{$\begin{array}{c}\text { Measured in } \\
\text { per ha or per } \\
\text { plot? }\end{array}$} & \multicolumn{4}{|c|}{ Quantity used (QU/plot/year) } & \multirow{3}{*}{$\begin{array}{c}\text { Average price of } \\
\text { input as used during } \\
\text { last } 12 \text { months ('000 } \\
\text { Rp/QU) }\end{array}$} \\
\hline & & & & & $\begin{array}{l}\text { Plot } 1 \\
+\end{array}$ & $\begin{array}{l}\text { Plot } 2 \\
+\end{array}$ & $\begin{array}{l}\text { Plot } 3 \\
+\end{array}$ & $\begin{array}{l}\text { Plot } 4 \\
+\end{array}$ & \\
\hline & & & & & \multicolumn{4}{|c|}{$\begin{array}{c}\text { (Fill all the columns if the plots are } \\
\text { different to each other) }\end{array}$} & \\
\hline $\begin{array}{l}\text { Seedlings (I } \\
\text { planting)* }\end{array}$ & & & Number & ha/ plot & & & & & \\
\hline $\begin{array}{l}\text { Seedlings } \\
\text { (replanting)* }\end{array}$ & & & Number & ha/plot & & & & & \\
\hline $\begin{array}{l}\text { Manure: Animal } \\
\text { waste }\end{array}$ & & & $\mathrm{kg}$ & & & & & & \\
\hline $\begin{array}{l}\text { Soil amendments } \\
\text { (lime, gypsum) }\end{array}$ & & & kg & ha/plot & & & & & \\
\hline Chemical fertilizers & & & $\mathrm{kg}$ & ha/plot & & & & & \\
\hline \multirow{2}{*}{ Herbicides } & & & litres & ha/plot & & & & & \\
\hline & & & litres & ha/ plot & & & & & \\
\hline \multirow[t]{3}{*}{ Pesticides } & & & litres & ha/plot & & & & & \\
\hline & & & litres & ha/plot & & & & & \\
\hline & & & litres & ha/plot & & & & & \\
\hline $\begin{array}{l}\text { Irrigation (excl. } \\
\text { labour cost) }\end{array}$ & & & ‘000 Rp & ha/plot & & & & & \\
\hline Machinery & & & ‘000 Rp & ha/plot & & & & & \\
\hline Input transport & & & ‘000 Rp & ha/plot & & & & & \\
\hline Output transport & & & ‘000 Rp & ha/plot & & & & & \\
\hline Others (specify) & & & ‘000 Rp & ha/plot & & & & & \\
\hline
\end{tabular}

*only if planting or replanting was done during the last 12 months

HH number: 
4.4.2. Labor use during last 12 months on main plot; plot ID:.........; unit of measurement:............. (per ha/ per plot).

\begin{tabular}{|c|c|c|c|c|c|c|c|c|c|c|c|}
\hline & \multicolumn{2}{|c|}{$\begin{array}{c}\text { No. of operations } \\
\text { during last } 12 \\
\text { months }\end{array}$} & \multirow[t]{2}{*}{$\begin{array}{l}\text { Time to } \\
\text { complete } \\
\text { one } \\
\text { operation }\end{array}$} & \multirow[t]{2}{*}{$\begin{array}{l}\text { Contracted } \\
\text { out the } \\
\text { operation? } \\
\text { (Yes/No) }\end{array}$} & \multirow[t]{2}{*}{$\begin{array}{l}\text { If contracted } \\
\text { out, cost of } \\
\text { operation } \\
\text { ('000 Rp) }\end{array}$} & \multicolumn{2}{|c|}{$\begin{array}{l}\text { If not contracted } \\
\text { out, } \\
\text { hired laborers } \\
\text { (number) }\end{array}$} & \multicolumn{2}{|c|}{$\begin{array}{c}\text { Wage rate } \\
\text { (000 Rp/day) }\end{array}$} & \multicolumn{2}{|c|}{$\begin{array}{l}\text { Family } \\
\text { members } \\
\text { involved/ } \\
\text { (number) }\end{array}$} \\
\hline & $\begin{array}{l}\text { Rainy } \\
\text { season }\end{array}$ & $\begin{array}{l}\text { Dry } \\
\text { season }\end{array}$ & & & & Man & Woman & Man & Woman & Men & Women \\
\hline \multicolumn{12}{|l|}{ Land clearing for planting } \\
\hline \multicolumn{12}{|l|}{ Other pre-planting activities } \\
\hline \multicolumn{12}{|l|}{ Taking pits for planting } \\
\hline \multicolumn{12}{|l|}{ Seedling transportation } \\
\hline \multicolumn{12}{|l|}{ Planting } \\
\hline \multicolumn{12}{|l|}{ Replanting } \\
\hline \multicolumn{12}{|l|}{ Manure application } \\
\hline \multicolumn{12}{|l|}{ Fertilizer application } \\
\hline \multicolumn{12}{|l|}{ Manual weeding on ground } \\
\hline \multicolumn{12}{|l|}{$\begin{array}{l}\text { Manual weeding on palm/ } \\
\text { trees }\end{array}$} \\
\hline \multicolumn{12}{|l|}{$\begin{array}{l}\text { Chemical weeding on } \\
\text { ground and on trees }\end{array}$} \\
\hline \multicolumn{12}{|l|}{ Pesticide application } \\
\hline \multicolumn{12}{|l|}{ Assisted pollination } \\
\hline \multicolumn{12}{|l|}{ Irrigation } \\
\hline \multicolumn{12}{|l|}{ Intercultural operations) } \\
\hline \multicolumn{12}{|l|}{ Tapping (only for rubber) } \\
\hline \multicolumn{12}{|l|}{ Harvesting } \\
\hline \multicolumn{12}{|l|}{ Processing } \\
\hline \multicolumn{12}{|l|}{ Transportation to market } \\
\hline \multicolumn{12}{|l|}{ Marketing } \\
\hline $\begin{array}{l}\text { Other (e.g. cutting leaves of } \\
\text { oil palm) }\end{array}$ & & & & & & & & & & & \\
\hline
\end{tabular}

For the enumerator: Have you asked whether the labour used in other plots differ significantly from main plot?............... (Yes /No /NA); If differ significantly, please use additional sheets to record the labour use in different plots.

HH number: ....................... 
5. Epiphyte management (only for oil palm farmers; avoid asking this question if farmer is not cultivating oil palm)

- When did you last use chemical herbicides to control weeds on trunk of oil palm? (date \& month; put NEVER if not done in last 12 months)

- When did you last manually clean the weeds on trunk of oil palm? (date \& month; put NEVER if not done in last 12 months)

Now please pictures of palm infested with epiphytes at different levels of infection.

\begin{tabular}{|c|c|c|c|c|}
\hline & $\begin{array}{l}\text { Epiphyte } \\
\text { picture } 1\end{array}$ & $\begin{array}{l}\text { Epiphyte } \\
\text { picture } 2\end{array}$ & $\begin{array}{l}\text { Epiphyte } \\
\text { picture } 3\end{array}$ & \\
\hline $\begin{array}{l}\text { 1. At of today, what percentage of palms is } \\
\text { there in your field with this level of } \\
\text { epiphyte infestation? (Total should be } \\
\text { 100\%) }\end{array}$ & $\%$ & $\%$ & $\%$ & \\
\hline $\begin{array}{l}\text { 2. Among the three stages, at what stage } \\
\text { do you regularly apply chemical } \\
\text { herbicides on the palm to control } \\
\text { epiphytes? (Tick only one of the } \\
\text { columns) }\end{array}$ & $\square$ & $\square$ & $\square$ & $\begin{array}{l}\square \text { Never do } \\
\text { chemical weeding } \\
\text { on palms }\end{array}$ \\
\hline $\begin{array}{l}\text { 3. Among the three stages, at what stage } \\
\text { do you regularly clean the palm } \\
\text { manually (cutting off epiphytes)? (Tick } \\
\text { only one of the columns) }\end{array}$ & $\square$ & $\square$ & $\square$ & $\begin{array}{l}\square \text { Never do } \\
\text { manual weeding } \\
\text { on palms }\end{array}$ \\
\hline
\end{tabular}

6. Outputs (both oil palm and rubber)

6.1. Outputs during last 12 months

\begin{tabular}{|c|c|c|c|c|c|c|c|}
\hline \multirow{2}{*}{$\begin{array}{l}\text { Sale ID }(1= \\
\text { most recent } \\
\text { sale) }\end{array}$} & \multirow[t]{2}{*}{ Date of sale $(\mathrm{dd} / \mathrm{mm})$} & \multirow{2}{*}{$\begin{array}{c}\text { Total } \\
\text { quantity } \\
\text { sold (kg) }\end{array}$} & \multicolumn{4}{|c|}{$\begin{array}{c}\text { Share of output obtained (\%) } \\
\text { from: }\end{array}$} & \multirow{2}{*}{$\begin{array}{c}\text { Average price } \\
\text { obtained for } \\
\text { output ('000 } \\
\text { Rp/kg) }\end{array}$} \\
\hline & & & $\begin{array}{c}\text { Plot } \\
1\end{array}$ & Plot 2 & Plot 3 & Plot 4 & \\
\hline \multicolumn{8}{|l|}{1} \\
\hline \multicolumn{8}{|l|}{2} \\
\hline \multicolumn{8}{|l|}{3} \\
\hline \multicolumn{8}{|l|}{ Annual } \\
\hline & $\begin{array}{r}\text { Total harvest in last } 12 \\
\text { months from all plots } \\
\text { (tons) }\end{array}$ & & & & & & \\
\hline
\end{tabular}

6.2. Please indicate how harvested quantity changed throughout the last 12 months

\begin{tabular}{|l|c|c|c|c|}
\hline Quarter of year & $\begin{array}{c}\text { Frequency of harvests } \\
\text { (once in how many } \\
\text { days?) }\end{array}$ & $\begin{array}{c}\text { Quantity } \\
\text { harvested per } \\
\text { month (kg/ha) }\end{array}$ & $\begin{array}{c}\text { Were there } \\
\text { any shock } \\
\text { events? (Code) }\end{array}$ & $\begin{array}{c}\text { Average price } \\
\text { obtained for output } \\
\text { in that quarter ('000 } \\
\mathrm{Rp} / \mathrm{kg} \text { ) }\end{array}$ \\
\hline Dry season & & & & \\
\hline Rain season & & & & \\
\hline
\end{tabular}

Code: none $=0 ;$ drought $=1 ;$ fire $=2 ;$ flood $=3$; theft $=4 ;$ pest $=5 ;$ others ( pecify) $=6$

6.3. Product marketing for the crop

HH number: 
- Number of times output was sold during the last 12 months:

(number)

- Through how many outlets the output was sold during last 12 months:

(number)

- During the last 12 months, from how many traders can you choose one for selling output ........................ (maximum number)

\begin{tabular}{|c|c|c|c|c|c|c|}
\hline \multirow[b]{2}{*}{$\begin{array}{l}\text { Outlets } \\
\text { (name) } \\
\text { where the } \\
\text { output was } \\
\text { sold in last } \\
12 \text { months }\end{array}$} & \multirow[b]{2}{*}{$\begin{array}{l}\text { Type } \\
\text { of } \\
\text { outlet } \\
\text { (Code } \\
\text { A) }\end{array}$} & \multirow[b]{2}{*}{$\begin{array}{l}\text { Do you } \\
\text { have a } \\
\text { contract } \\
\text { relation } \\
\text { with } \\
\text { outlet? }\end{array}$} & \multirow[b]{2}{*}{$\begin{array}{l}\text { \% of output } \\
\text { sold through } \\
\text { this outlet } \\
\text { during the last } \\
12 \text { months }\end{array}$} & \multicolumn{3}{|c|}{ Product transport to the outlet point } \\
\hline & & & & $\begin{array}{l}\text { in } \mathrm{km} \\
\text { ( } 0 \text { if } \\
\text { purchased } \\
\text { at farm- } \\
\text { gate) }\end{array}$ & $\begin{array}{c}\text { mode of } \\
\text { transportation } \\
\text { (Code } \mathrm{B})\end{array}$ & $\begin{array}{l}\text { time taken for } \\
\text { transportation } \\
\text { (hours) }\end{array}$ \\
\hline 1. & & Yes/ No & & & & \\
\hline 2. & & Yes/ No & & & & \\
\hline 3. & & Yes/ No & & & & \\
\hline 4. & & Yes/ No & & & & \\
\hline 5. & & Yes/ No & & & & \\
\hline 6. & & Yes/ No & & & & \\
\hline
\end{tabular}

Code $\mathrm{A}$ : private plantation $=1$; government plantation $=2$; private trader in village $=3$; private trader outside village $=4$; farmer group or cooperative $=5$; others ( ppecify) $=6$; Code B: farm-gate selling $=0$; walking $=1$; cycle $=2$; ojek $=3$; angkot $=4$; bus $=5 ;$ truck $=6$; tractor $=7$; others (specify) $=8$

6.4. By-products produced and collected from the planation during the last 12 months

\begin{tabular}{|l|l|c|c|c|}
\hline $\begin{array}{l}\text { By-product type } \\
\text { (name) }\end{array}$ & $\begin{array}{c}\text { Unit of } \\
\text { measurement } \\
\text { (QU; name) }\end{array}$ & $\begin{array}{c}\text { Average production or } \\
\text { collection (QU) in last } \\
12 \text { months }\end{array}$ & $\begin{array}{c}\text { Quantity (QU) } \\
\text { marketed in last 12 } \\
\text { months }\end{array}$ & $\begin{array}{c}\text { Average price } \\
\text { obtained ('000 } \\
\text { Rp/QU) }\end{array}$ \\
\hline 1. Timber & & & & \\
\hline 2. Firewood & & & & \\
\hline 3. & & & & \\
\hline & & & & \\
\hline
\end{tabular}

HH number: 
7. Cultivation of other crops during the last 12 months (including the kitchen garden)

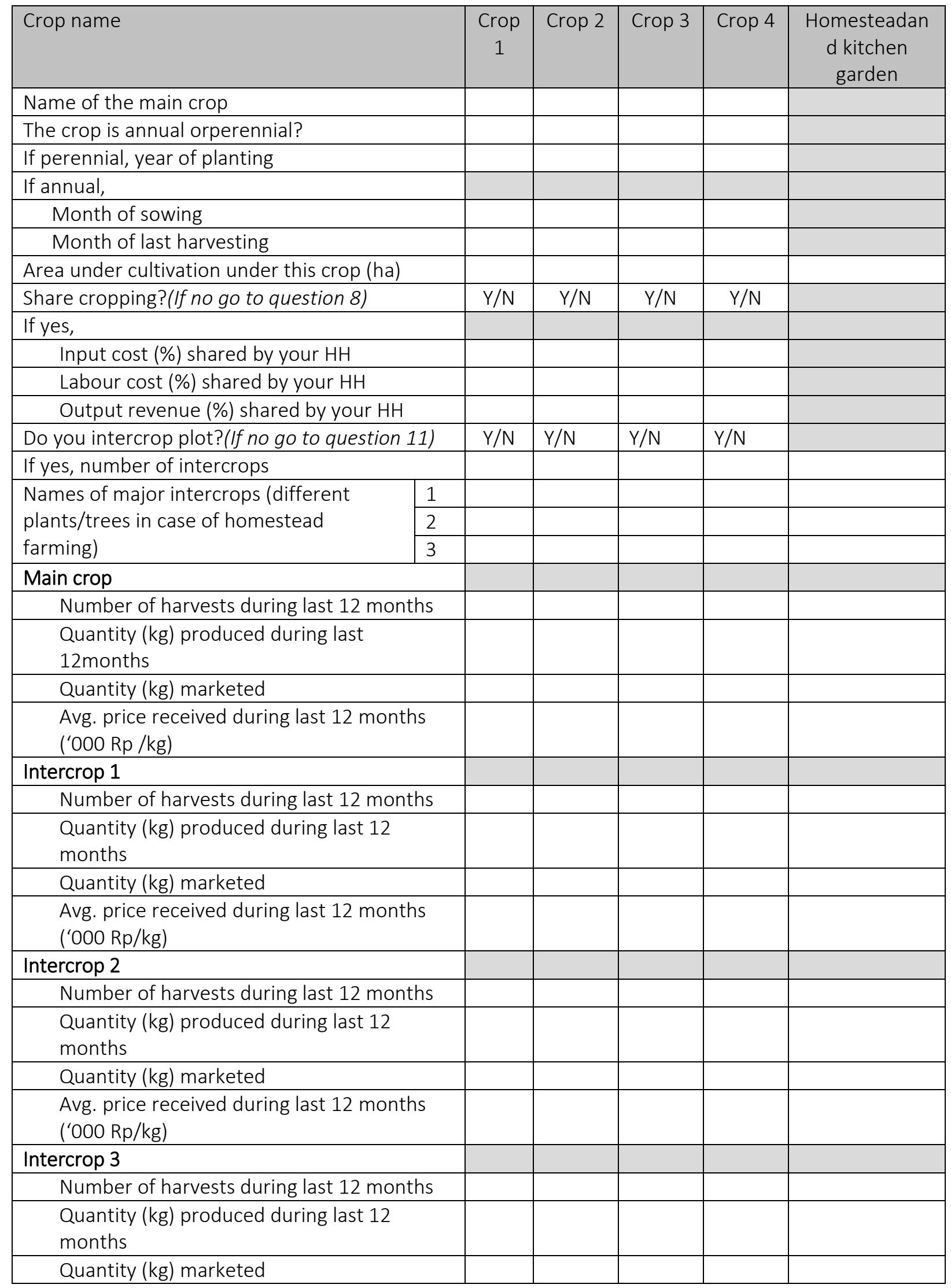

HH number: 


\begin{tabular}{|l|l|l|l|l|l|}
\hline Crop name & $\begin{array}{c}\text { Crop } \\
1\end{array}$ & Crop 2 & Crop 3 & \begin{tabular}{c} 
Crop 4 \\
\hline $\begin{array}{l}\text { Avg. price received during last 12 months } \\
\text { ('000 Rp/kg) }\end{array}$
\end{tabular} & $\begin{array}{c}\text { Homeadan } \\
\text { d kitchen } \\
\text { garden }\end{array}$ \\
\hline $\begin{array}{l}\text { Quantity of inputsapplied for the crop plots } \\
\text { (quantity/season for annuals or quantity/year } \\
\text { for perennials) for main and inter crops in last } \\
12 \text { months }\end{array}$ & & & & & \\
\hline $\begin{array}{l}\text { Seeds/Seedlings ('000 Rp spent by } \\
\text { household) }\end{array}$ & & & & & \\
\hline $\begin{array}{l}\text { Manures ('000 Rp spent by household) } \\
\text { Chemical fertilizers ('000 Rp spent by } \\
\text { household) }\end{array}$ & & & & & \\
\hline $\begin{array}{l}\text { Pesticides ('000 Rp spent by household) } \\
\text { Herbicides ('000 Rp spent by household) }\end{array}$ & & & & & \\
\hline $\begin{array}{l}\text { Hired labour - male and female ('000 Rp } \\
\text { spent by HH) }\end{array}$ & & & & & \\
\hline $\begin{array}{l}\text { Hired animal/machine labour ('000 Rp. spent } \\
\text { by HH) }\end{array}$ & & & & & \\
\hline
\end{tabular}

HH number: 
8. Forest dependent activities: Include all the timber and non-timber products your household collects or used to collect.

- How far away is the closest forest from your household (walking minutes, put NF if there is no forest within walking distance)?..........

\begin{tabular}{|l|c|c|c|c|c|c|c|}
\hline $\begin{array}{l}\text { Forest product } \\
\text { collected } \\
\text { (name) }\end{array}$ & $\begin{array}{c}\text { How often do } \\
\text { you collect it or } \\
\text { do it? (Once in --- } \\
\text { Days) }\end{array}$ & $\begin{array}{c}\text { How many } \\
\text { members of your } \\
\text { HH are involved in } \\
\text { collection/ } \\
\text { activity? (number) }\end{array}$ & $\begin{array}{c}\text { How many other } \\
\text { households are } \\
\text { involved in this } \\
\text { activity? } \\
\text { (number) }\end{array}$ & $\begin{array}{c}\text { Quantity } \\
\text { obtained } \\
\text { during last } \\
12 \text { months } \\
\text { year (in QU) }\end{array}$ & $\begin{array}{c}\text { Quantity } \\
\text { sold during } \\
\text { last 12 } \\
\text { months (in } \\
\text { QU) }\end{array}$ & $\begin{array}{c}\text { Average price } \\
\text { obtained } \\
\text { (Rp/QU) during } \\
\text { last 12 months }\end{array}$ & $\begin{array}{c}\text { Share of revenue } \\
\text { (\%) for your } \\
\text { household if more } \\
\text { than } 1 \text { households } \\
\text { are involved }\end{array}$ \\
\hline Timber & & & & & & & \\
\hline Honey & & & & & & & \\
\hline Rattan & & & & & & & \\
\hline Firewood & & & & & & & \\
\hline Birds & & & & & & & \\
\hline Hunting & & & & & & & \\
\hline
\end{tabular}

\section{Livestock production}

a. Animals possessed and produced by the household during the last 12 months

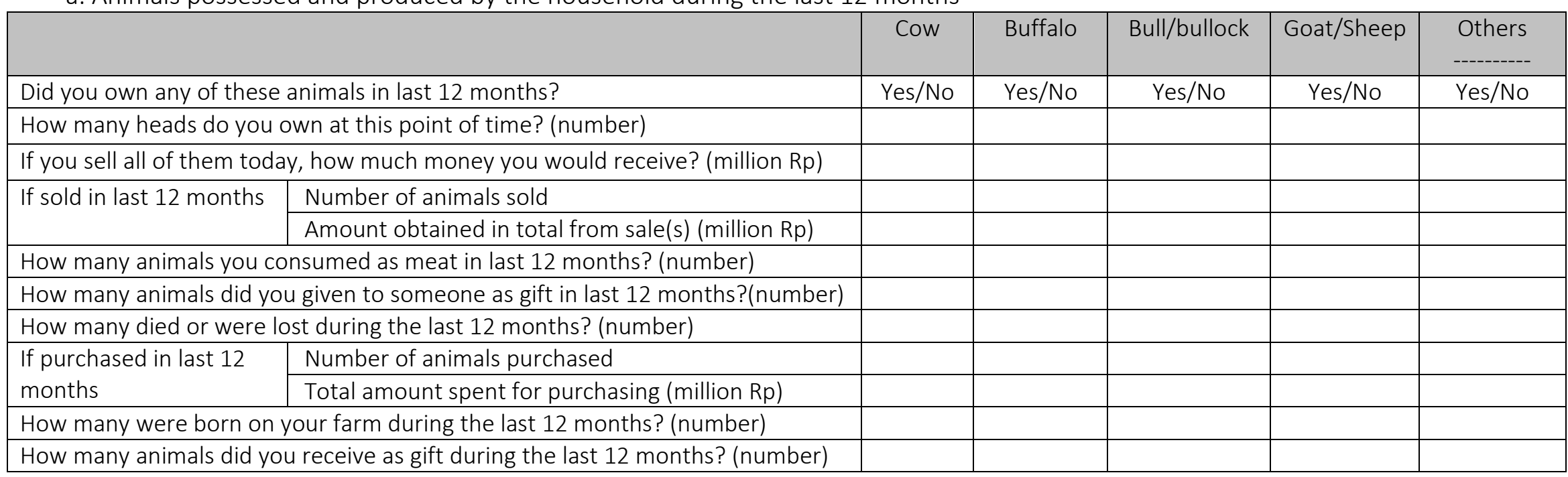

HH number: 
b. Chicken and duck

\begin{tabular}{|c|c|c|c|}
\hline & Chicken & Duck & Other birds \\
\hline $\begin{array}{l}\text { 1. Did you own any of these birds in last } 12 \text { months? (If no, } \\
\text { go to next column or section) }\end{array}$ & Yes/No & Yes/No & Yes/No \\
\hline $\begin{array}{l}\text { 2. How many heads do you own at this point of time? } \\
\text { (number) }\end{array}$ & & & \\
\hline $\begin{array}{l}\text { 3. How much did you spend on feed per month for all } \\
\text { birds? (Rp) }\end{array}$ & & & \\
\hline $\begin{array}{l}\text { 4. How much did you spend on hired labour per month on } \\
\text { these birds? (Rp.) }\end{array}$ & & & \\
\hline $\begin{array}{l}\text { 5. Other costs (e.g. breeding) incurred to keep the birds? } \\
\text { (Rp/year) }\end{array}$ & & & \\
\hline 6. Main product type (Code) & & & \\
\hline $\begin{array}{l}\text { a. Unit of measurement of main product (QU; } \\
\text { name) }\end{array}$ & & & \\
\hline b. Quantity produced in last 12 months (QU) & & & \\
\hline c. Price of main product if marketed (Rp/QU) & & & \\
\hline 7. By-product type (Code) & & & \\
\hline a. Unit of measurement of by-product (QU; name) & & & \\
\hline b. Quantity produced in last 12 months (QU) & & & \\
\hline c. $\quad$ Price of by-product if marketed (Rp/QU) & & & \\
\hline
\end{tabular}

Code $\mathrm{B}$ : eggs $=1 ;$ meat $=2 ;$ manure $=3$; others $($ specify $)=4$

C. Fish culture

\begin{tabular}{|c|c|c|c|}
\hline $\begin{array}{l}\text { 1. Have you involved in fish culture in the last } 12 \text { months? (If no, go } \\
\text { to next section) }\end{array}$ & \multicolumn{3}{|c|}{ Yes/No } \\
\hline 2. Number of households involved in fish cultivation (if done jointly)? & & & \\
\hline 3. Number of ponds under cultivation & & & \\
\hline \multicolumn{4}{|l|}{ 4. Total size of all fish ponds under cultivation (ha) } \\
\hline & Fish type 1 & Fish type 2 & Fish type 3 \\
\hline 5. Name of major fish types being grown & & & \\
\hline 6. How often did you harvest during the last 12 months? & & & \\
\hline 7. What is the average quantity of fish obtained per harvest (kg)? & & & \\
\hline 8. Did you sell fish? & Yes/No & Yes/No & Yes/No \\
\hline 9. Amount of fish sold during last 12 months (kg)? & & & \\
\hline \multicolumn{4}{|l|}{ 10. If sold, average price obtained ( $\mathrm{Rp} / \mathrm{kg})$ ? } \\
\hline \multicolumn{4}{|l|}{$\begin{array}{l}\text { 11. How much did you spend on fish feed during the last } 12 \text { months } \\
\text { ('000 Rp)? }\end{array}$} \\
\hline \multicolumn{4}{|l|}{$\begin{array}{l}\text { 12. How much did you spend on non-feed materials during the last } 12 \\
\text { months ('000 Rp)? }\end{array}$} \\
\hline $\begin{array}{l}\text { 13. How much did you pay for hired labour during last } 12 \text { months } \\
\text { ('000 Rp)? }\end{array}$ & & & \\
\hline
\end{tabular}

HH number: 


\section{d. Fishing}

\begin{tabular}{|ll|l|}
\hline 1. & Apart from fish pond cultivation, do you or any of your HH members go fishing? & $\begin{array}{c}\text { Yes/No } \\
\text { (if no, go to next section) }\end{array}$ \\
\hline 2. & How many of your HH members go for fishing? (number) & \\
\hline 3. & How often do you or your HH members go fishing? (once in .....days) & \\
\hline 4. & How much time do you spend on average when you go fishing (hours/day)? & \\
\hline 5. & What is the quantity of fish you obtain on an average month? (kg) & \\
\hline 6. & What is the quantity of fish you sell on an average month? (kg) & \\
\hline 7. & How much money did you receive from fishing on an average month? ('O0O Rp) & \\
\hline
\end{tabular}

\subsection{Permanent labour employment}

- How many permanent laborers are employed on your farm? (number):.

- Wages paid per month: '000 Rp. ./month.

\section{Credit}

\section{- Formal institutions}

- Have you taken credit during the last 12 months from a bank, farmer group or cooperative?..........(Yes/No)

- If yes, type of the institute ............ (Code: Bank = 1; farmer group = 2; farmer cooperative = 3)

- If no, what was the main reason for not taking credit? ............ (Code; Not required or necessary = 1; Can easily obtain from friends or family $=2$; It is difficult to get $=3$; High interest rate $=4$; No land title to pledge to get credit $=5$; It is morally wrong to take credit $=6$; Others $=7$ (specify:

- If credit is taken from a bank in last 12 months from a bank/ farmer group/ cooperative/ other formal groups:

\begin{tabular}{|l|l|l|l|l|}
\hline & Bank & Cooperative & Farmer group & Others \\
\hline 1. Amount taken ('000Rp) & & & & \\
\hline 2. Rate of interest (\% annual) & & & & \\
\hline 3. Repayment period (month) & & & & \\
\hline 4. \% of credit used for consumption & & & & \\
\hline 5. \% of credit used for farming & & & & \\
\hline 6. If used for farming, \% used for oil palm & & & & \\
\hline $\begin{array}{l}\text { a. \% used for plantation rubber } \\
\text { b. \% used for jungle rubber }\end{array}$ & & & & \\
\hline $\begin{array}{l}\text { 7. Did you have to submit your land } \\
\text { title/certificate to get the credit? }\end{array}$ & Yes / No & Yes / No & Yes / No & Yes / No \\
\hline
\end{tabular}

HH number: 
Informal credit sources

- Have you taken credit during the last 12 months from other households/trader/ input dealer? (Yes/ No)

- If yes, type of the institute (Code: Other household = 1; Trader $=2 ;$ Input dealer $=3$ )

- If no, what was the main reason for not taking credit? . (Code; Not required or necessary $=1$; Can easily obtain from banks or other formal source $=2$; It is difficult to get $=3$; High interest rate $=4$; No land title to pledge to get credit $=5$; It is morally wrong to take credit $=6$; Others $=7$ (specify:

- If credit is taken in last 12 months from farmer/trader/ dealer/ relative/ other informal sources:

\begin{tabular}{|c|c|c|c|}
\hline & \multicolumn{3}{|c|}{ Traders of output } \\
\hline & Trader 1 & Trader 2 & Trader 3 \\
\hline 1. Name of the trader who provides credit & & & \\
\hline $\begin{array}{l}\text { 2. Output handled by the trader (Code: Oil palm }=1 \text {; rubber } \\
=2 \text {; rice }=3 \text {; others }=4 \text { ). }\end{array}$ & & & \\
\hline 3. Total credit amount taken in last 12 months ('000 Rp) & & & \\
\hline 4. Interest rate (\% annual; put 0 if it is interest free) & & & \\
\hline 5. Mutually agreed repayment period (months) & & & \\
\hline $\begin{array}{l}\text { 6. Does the repayment is taken place through a reduction in } \\
\text { the product price (against repayment in cash)? }\end{array}$ & Yes / No & Yes / No & Yes / No \\
\hline 7. $\%$ of credit used for consumption & & & \\
\hline 8. \% of credit used for farming & & & \\
\hline 9. If used for farming, & & & \\
\hline a. $\%$ used for oil palm & & & \\
\hline b. $\%$ used for rubber & & & \\
\hline $\begin{array}{l}\text { 10. Did you have to submit your land title/certificate to } \\
\text { get the credit? }\end{array}$ & Yes / No & Yes / No & Yes / No \\
\hline
\end{tabular}

- If credit is taken in last 12 months from another households:

\begin{tabular}{|c|c|c|c|c|}
\hline & \multicolumn{4}{|c|}{ Other household (major credit sources) } \\
\hline & $\mathrm{HH} 1$ & $\mathrm{HH} 2$ & $\mathrm{HH} 3$ & $\mathrm{HH} 4$ \\
\hline 1. Whether this household was a farmer household? & Yes/No & Yes/No & Yes/No & Yes/No \\
\hline 2. Total amount taken in last 12 months ('000 Rp) & & & & \\
\hline 3. Interest rate (\% annual; put 0 if it is interest free) & & & & \\
\hline $\begin{array}{l}\text { 4. Mutually agreed repayment period (months; NA if } \\
\text { not fixed) }\end{array}$ & & & & \\
\hline 5. His/her farm size (ha; 0 if non-farmer) & & & & \\
\hline $\begin{array}{l}\text { 6. Shortest distance between your farm and his/her } \\
\text { (km; NA if not a farmer) }\end{array}$ & & & & \\
\hline 7. Is she/he your relative or friend? & Yes / No & Yes / No & Yes / No & Yes / No \\
\hline 8. Does she/he belong to your village? & Yes / No & Yes / No & Yes / No & Yes / No \\
\hline 9. Does she/he belong to your dusun? & Yes / No & Yes / No & Yes / No & Yes / No \\
\hline 10. What is the distance between your houses $(\mathrm{km})$ & & & & \\
\hline
\end{tabular}

HH number: 


\begin{tabular}{|c|c|c|c|c|}
\hline & \multicolumn{4}{|c|}{ Other household (major credit sources) } \\
\hline & $\mathrm{HH} 1$ & $\mathrm{HH} 2$ & $\mathrm{HH} 3$ & $\mathrm{HH} 4$ \\
\hline 11. Do you both belong to same ethnic community? & Yes/No & Yes /No & Yes / No & Yes / No \\
\hline $\begin{array}{l}\text { 12. Did he/she borrow money from you in past } 12 \\
\text { months? }\end{array}$ & Yes / No & Yes / No & Yes / No & Yes / No \\
\hline 13. \% of credit used for consumption & & & & \\
\hline 14. \% of credit used for farming & & & & \\
\hline 15. If used for farming, & & & & \\
\hline a. $\%$ used for oil palm & & & & \\
\hline b. \% used for plantation rubber & & & & \\
\hline $\begin{array}{l}\text { 16. Did you have to submit your land } \\
\text { title/certificate to get the credit? }\end{array}$ & Yes / No & Yes / No & Yes / No & Yes / No \\
\hline
\end{tabular}

- Credit networks among farmer households from same dusun

\begin{tabular}{|c|c|c|c|c|c|}
\hline $\begin{array}{l}\text { Name of farmer } \\
\text { (Indicate that they } \\
\text { are randomly } \\
\text { selected from the } \\
\text { dusun) }\end{array}$ & $\begin{array}{l}\text { Do you know } \\
\text { him/her } \\
\text { personally? (if } \\
\text { no, go to next } \\
\text { row or section) }\end{array}$ & $\begin{array}{l}\text { Is s/he your } \\
\text { relative? }\end{array}$ & $\begin{array}{l}\text { Have you ever } \\
\text { taken a credit } \\
\text { from him in } \\
\text { the last } 3 \\
\text { years? }\end{array}$ & $\begin{array}{l}\text { If you need a } \\
\text { credit do you } \\
\text { think you would } \\
\text { approach } \\
\text { him/her?* }\end{array}$ & $\begin{array}{l}\text { If yes, what is the } \\
\text { maximum amount of } \\
\text { credit you can avail } \\
\text { from him/her at a } \\
\text { time? ('000 Rp) }\end{array}$ \\
\hline 1. & Yes /No & Yes /No & Yes /No & Yes /No & \\
\hline 2. & Yes /No & Yes /No & Yes /No & Yes /No & \\
\hline 3. & Yes /No & Yes /No & Yes /No & Yes /No & \\
\hline 4. & Yes /No & Yes/No & Yes /No & Yes /No & \\
\hline 5. & Yes /No & Yes /No & Yes /No & Yes /No & \\
\hline
\end{tabular}

\section{Household characteristics}

10.1. Asset ownership by household

\begin{tabular}{|l|c|c|c|}
\hline $\begin{array}{l}\text { Article (in } \\
\text { working } \\
\text { condition) }\end{array}$ & $\begin{array}{c}\text { Number } \\
\text { owned }\end{array}$ & $\begin{array}{c}\text { Year of } \\
\text { purchase }\end{array}$ & $\begin{array}{c}\text { Purchase } \\
\text { price ('000 } \\
\text { Rp) }\end{array}$ \\
\hline $\begin{array}{l}\text { Television } \\
\text { (color) }\end{array}$ & & & \\
\cline { 3 - 4 } & & & \\
\hline Satellite dish & & & \\
\hline Motor bike & & & \\
\cline { 3 - 4 } & & & \\
\hline Car & & & \\
\hline Jeep/Truck/ & & & \\
\hline Angkot & & & \\
\cline { 3 - 4 } & & & \\
\hline
\end{tabular}

\begin{tabular}{|l|l|l|l|}
\hline $\begin{array}{l}\text { Article (in } \\
\text { working } \\
\text { condition) }\end{array}$ & $\begin{array}{c}\text { Number } \\
\text { owned }\end{array}$ & $\begin{array}{c}\text { Year of } \\
\text { purchase }\end{array}$ & $\begin{array}{c}\text { Purchase } \\
\text { price } \\
\text { ('000 Rp) }\end{array}$ \\
\hline Fridge & & & \\
\cline { 3 - 4 } & & & \\
\hline $\begin{array}{l}\text { Washing } \\
\text { machine }\end{array}$ & & & \\
\hline $\begin{array}{l}\text { 4-wheel } \\
\text { tractor }\end{array}$ & & \\
\hline \multicolumn{3}{|c|}{ Number of cell phones owned by the } \\
\multicolumn{3}{|c|}{ household:....................... } \\
\hline
\end{tabular}

HH number: 
10.2. Household member details

\begin{tabular}{|c|c|c|c|c|c|c|c|c|}
\hline \multirow{2}{*}{$\begin{array}{l}\mathrm{HH} \text { member (Name or } \\
\text { relationship with } \mathrm{HoH} \text { ) }\end{array}$} & \multirow{2}{*}{$\begin{array}{c}\text { Member } \\
\text { ID }\end{array}$} & \multirow{2}{*}{$\begin{array}{c}\text { Age } \\
\text { (years) }\end{array}$} & \multirow{2}{*}{$\begin{array}{l}\text { Sex } \\
(\mathrm{m} / \mathrm{f})\end{array}$} & \multirow{2}{*}{$\begin{array}{l}\text { marital status } \\
(\text { married }=1 \\
\text { unmarried }=0)\end{array}$} & \multirow{2}{*}{$\begin{array}{l}\text { Education } \\
\text { (number of } \\
\text { years in school } \\
\text { and college) }\end{array}$} & \multirow{2}{*}{$\begin{array}{l}\text { Last } \\
\text { graduation } \\
\text { (Code A) }\end{array}$} & \multicolumn{2}{|c|}{ Main Occupations (Code B) } \\
\hline & & & & & & & Primary & Secondary \\
\hline 1. Respondent & 1 & & & & & & & \\
\hline 2. Head of household* & 2 & & & & & & & \\
\hline 3. & 3 & & & & & & & \\
\hline 4. & 4 & & & & & & & \\
\hline 5. & 5 & & & & & & & \\
\hline 6. & 6 & & & & & & & \\
\hline 7. & 7 & & & & & & & \\
\hline 8. & 8 & & & & & & & \\
\hline 9. & 9 & & & & & & & \\
\hline 10. & 10 & & & & & & & \\
\hline 11. & 11 & & & & & & & \\
\hline 12. & 12 & & & & & & & \\
\hline 13. & 13 & & & & & & & \\
\hline 14. & 14 & & & & & & & \\
\hline 15. & 15 & & & & & & & \\
\hline
\end{tabular}

* Do not fill this column if respondent is head of the household. Use more rows if household size is more than 15.

Code A: never attended=1; attended but not completed=2; completed SD(primary)=3; completed SMP(Middle)=4; completed SMA(High School)=5; D3 or S1 (Associates Degree or University level first stage) $=6$; student at present $=7$.

Code B: own-agriculture=1; wage or contract labour=2; own-business activities=3; still attending school=4; household activities=5; other ( specify)=6 
b. Residency status of household members

\begin{tabular}{|l|c|c|c|}
\hline \multirow{2}{*}{} & Used to live in the & \multicolumn{2}{|c|}{ If no, answer the following questions } \\
\cline { 4 - 4 } & village whole life? & Year of migration to the village & \multicolumn{2}{|c}{ From where moved to the village (Code) } \\
\hline Head of the household $(\mathrm{HoH})$ & Yes / No & & \\
\hline Parents of the $\mathrm{HoH}$ & Yes / No & & \\
\hline Spouse of the $\mathrm{HoH}$ & Yes / No & & \\
\hline Parents of the spouse & Yes / No & & \\
\hline
\end{tabular}

Code: outside village in Jambi = 1; outside Jambi, but in Sumatra = 2; outside Sumatra, but in Indonesia = 3; Outside Indonesia = 4

c. Religion of HoH: Muslim/ Christian/ Hindu/ Buddhist/ Others (specify: ...).

d. Ethnic group (specify):

\section{Non-own agriculture household income sources}

11.1Wage and contract labour

- Have any of your household members worked as dailylaborer (daily /weekly / monthly payment of money) or as permanentlaborer (fixed payment for specific jobs)during the last 12 months? ................ (Yes/No). If no please go to 11.2.

\begin{tabular}{|l|c|c|c|c|c|c|c|}
\hline $\begin{array}{l}\text { Member ID (from } \\
\text { Table 10.2a) }\end{array}$ & $\begin{array}{c}\text { Type of } \\
\text { activity } \\
\text { (Code A) }\end{array}$ & $\begin{array}{c}\text { Type of } \\
\text { payment(Code } \\
\text { B) }\end{array}$ & $\begin{array}{c}\text { Seasonal (=0) } \\
\text { or permanent } \\
(=1) ?\end{array}$ & $\begin{array}{c}\text { If permanent, } \\
\text { wage rate ('000 } \\
\text { Rp/month) }\end{array}$ & $\begin{array}{c}\text { No. of months } \\
\text { worked } \\
\text { in last 12 months }\end{array}$ & $\begin{array}{c}\text { No. of days } \\
\text { engaged per work } \\
\text { months }\end{array}$ & $\begin{array}{c}\text { Average amount } \\
\text { earned/received during a } \\
\text { month worked ('000 Rp.) }\end{array}$ \\
\hline & & & & & & & \\
\hline & & & & & & & \\
\hline & & & & & & & \\
\hline
\end{tabular}

Code A: work in agriculture $=1$; work in forestry $=2$; work in manufacturing $=3$; work in services $=4$; government employee $=5$; other (specify) $=6$

Code B: no contract = 0; per hour wage $=1$; daily wage $=2$; weekly wage $=3$; monthly wage $=4$; contract (fixed arrangement) $=6$; other arrangement $($ specify) $=7$.

HH number: 
11.2. Own business activities

a. Did any of your household members gain any income from any type ofown-business activities during the last 12 months?............... (Yes/No) If no please go to 11.3.

\begin{tabular}{|c|c|c|c|c|c|c|c|}
\hline $\begin{array}{l}\text { Type of } \\
\text { enterprise or } \\
\text { business } \\
\text { (Code) }\end{array}$ & $\begin{array}{l}\text { Shortly describe the } \\
\text { type of business in } \\
\text { words }\end{array}$ & $\begin{array}{l}\text { When } \\
\text { started? } \\
\text { (year) }\end{array}$ & $\begin{array}{l}\text { No. of } \\
\text { family } \\
\text { members } \\
\text { engaged }\end{array}$ & $\begin{array}{c}\text { Household member who } \\
\text { ismainly responsible for the } \\
\text { business (ID from } 10.2 a \text { ) }\end{array}$ & $\begin{array}{c}\text { Total hours worked } \\
\text { a member on } \\
\text { average month in } \\
\text { business? }\end{array}$ & $\begin{array}{l}\text { Total amount earned } \\
\text { from business per } \\
\text { month on average? } \\
\text { ('000 Rp). }\end{array}$ & $\begin{array}{l}\text { Number of } \\
\text { monthsthe business } \\
\text { was running during } \\
\text { last } 12 \text { months? }\end{array}$ \\
\hline & & & & & & & \\
\hline & & & & & & & \\
\hline & & & & & & & \\
\hline & & & & & & & \\
\hline
\end{tabular}

Code: shop=1; trading=2; restaurant (food) =3; hotel (stay) =4; chauffeur/driver =5; carpenter=6; construction worker=7; other (specify)=8.

11.3 Public and private transfers

- Have any of your household members benefited from some kind of public/NGO transfer program (given money in daily/weekly/monthly basis) during the last 12 months? ........................(Yes/ No). If no, go to section 11.4 .

\begin{tabular}{|c|c|c|c|c|}
\hline $\begin{array}{c}\text { Member IDs } \\
\text { (from 10.2a) }\end{array}$ & $\begin{array}{c}\text { Type of program } \\
\text { (Code A) }\end{array}$ & $\begin{array}{c}\text { Who is providing the program? } \\
\text { (Code B) }\end{array}$ & $\begin{array}{c}\text { What kind of benefits do you } \\
\text { receive? (Code C) }\end{array}$ & $\begin{array}{c}\text { Estimated amount received during } \\
\text { last 12 months ('000 Rp.) }\end{array}$ \\
\hline & & & & \\
\hline & & & & \\
\hline & & & & \\
\hline & & & & \\
\hline
\end{tabular}

Code A: pensions=1; education subsidies=2; health care benefits=3; poverty reduction program=4; others (specify)=5.; Code B: local government=1; federal government=2; $\mathrm{NGO}=3$; other ( pecify)=4.; Code C: cash=1; clothes=2; food=3; agricultural inputs =4; others (specify)=5. 
11.4 Private transfers and remittances

- Did your household sent any money to anybody (e.g.afamily member, not included in 10.2a) staying outside the household during the last 12 months? .......... (Yes/No).

- Did anybody(e.g.afamily member, not included in 10.2a) staying outside the household sent moneyto your household during the last 12 months? .......... (Yes/No). If yes to any of the above questions:

\begin{tabular}{|c|c|c|c|c|}
\hline \multicolumn{2}{|c|}{ If money is sent outside } & \multicolumn{2}{|c|}{ If money is received from outside } & \multirow{2}{*}{$\begin{array}{l}\text { Region where the sender } \\
\text { or receiver resides (Code } \\
\text { B) }\end{array}$} \\
\hline $\begin{array}{c}\text { Receiver's relation with your } \\
\text { household head } \\
\text { (Code A) }\end{array}$ & $\begin{array}{l}\text { Estimated amount sent during } \\
\text { last } 12 \text { months ('000 Rp.) }\end{array}$ & $\begin{array}{c}\text { Sender's relation you're your } \\
\text { household head } \\
\text { (Code A) }\end{array}$ & $\begin{array}{l}\text { Estimated amount received during } \\
\text { last } 12 \text { months ('000 Rp.) }\end{array}$ & \\
\hline & & & & \\
\hline & & & & \\
\hline & & & & \\
\hline & & & & \\
\hline & & & & \\
\hline
\end{tabular}

Code A: Son or daughter=1; father or mother=2; grandchild=3; mother or father in law=4; son or daughter in law=5; other relative=6; non-relative=7. ; Code

B: outside village in Jambi = 1; outside Jambi, but in Sumatra = 2; outside Sumatra, but in Indonesia = 3; Outside Indonesia $=4$.

\section{Membership in the village-level organizations in last 12 months}

\begin{tabular}{|l|l|l|l|}
\hline $\begin{array}{l}\text { Household member } \\
\text { ID (see Table 10.2a) }\end{array}$ & Name of organization & Position in organization & Comments \\
\hline & & & \\
\hline & & & \\
\hline & & & \\
\hline
\end{tabular}

Thank you for participating in the survey! (Continue the consumption survey with the housewife)

HH number: 


\section{HOUSEHOLD CONSUMPTION QUESTIONNAIRE.}

\section{Household identification}

1. Village (name):

2. Dusun (name or number):

3. RT (number):

4. Household code (given by supervisor):

5. Name of respondent:

6. Sex of respondent:

7. Are you responsible for the purchase of

8. Name of head of household:

\begin{tabular}{|c|c|c|c|}
\hline \multicolumn{4}{|l|}{ upervisor): } \\
\hline & Male / Female & & \\
\hline \multirow[t]{2}{*}{ purchase of } & Food & Non-food materials & Services \\
\hline & Fully/Partly/No & Fully/Partly/No & Fully/Partly/No \\
\hline
\end{tabular}

9. Respondent's relationship with head of household (code):

10. Number of persons regularly consuming food from your house in last 7 days:

11. Interviewer (name):

12. Supervisor (name):

13. Date of interview

14. Date questionnaire was checked by supervisor:

Male / Female

\begin{tabular}{|l|l|l}
\hline Fully/Partly/No & Fully/Partly/No & Fully/Partly/No
\end{tabular}

Code: 1: Wife/Husband; 2: Daughter/Son; 3: Mother/Father; 4: Sister/Brother; 5: Niece/Nephew; 6: Others (specify)

2. Household expenditure: In the following questions, we want to ask about all items consumed in your household, regardless of which person consumed it.

2.1. Weekly consumption: Has your household consumed following goods during the past 7 days? Please exclude from your answer any purchases for processing or resale in a household enterprise.

\begin{tabular}{|ll|l|l|c|c|}
\hline \multirow{2}{*}{ Item consumed } & \multirow{2}{*}{$\begin{array}{c}\text { Quantity } \\
\text { consumed in last } \\
\end{array}$} & week (units) & Unit (number, liter, kg, bag, pieces, etc.) & Market price, \\
& & & $\begin{array}{c}\text { How much kg or litre } \\
\text { if purchased } \\
\text { (approx..) one unit is? }\end{array}$ & \\
\hline 1) & Rice (whole) & & & & \\
\hline 2) & Rice flour & & & & \\
\hline 3) & Wheat (whole) & & & & \\
\hline 4) & Wheat flour & & & & \\
\hline 5) & Maize & & & & \\
\hline 6$)$ & Other cereals & & & & \\
\hline 7) & Long bean & & & & \\
\hline
\end{tabular}

HH number: 


\begin{tabular}{|c|c|c|c|c|c|}
\hline & \multirow{2}{*}{$\begin{array}{c}\text { Quantity } \\
\text { consumed in last } \\
\text { week (units) }\end{array}$} & \multicolumn{2}{|c|}{ Unit (number, liter, kg, bag, pieces, etc.) } & \multirow{2}{*}{$\begin{array}{c}\text { Market price, } \\
\text { if purchased } \\
\text { (Rp./unit) }\end{array}$} \\
\hline \multicolumn{2}{|c|}{ Item consumed } & & & & \\
\hline 8) & Cassava & & & & \\
\hline 9) & Flour of cassava & & & & \\
\hline 10) & Potato & & & & \\
\hline 11) & Sweet potato & & & & \\
\hline 12) & Gaplek & & & & \\
\hline 13) & Taro & & & & \\
\hline 14) & Sago & & & & \\
\hline 15) & Fish (fresh) & & & & \\
\hline 16) & Fish (dry) & & & & \\
\hline 17) & Seafood & & & & \\
\hline 18) & Beef & & & & \\
\hline 19) & Chicken & & & & \\
\hline 20) & Duck & & & & \\
\hline 21) & Mutton & & & & \\
\hline 22) & Buffalo & & & & \\
\hline 23) & Goat & & & & \\
\hline 24) & Lamb & & & & \\
\hline 25) & Sheep & & & & \\
\hline 26) & Entrails & & & & \\
\hline 27) & Liver & & & & \\
\hline 28) & Spleen & & & & \\
\hline 29) & Dried jerky meat & & & & \\
\hline 30) & Eggs of chicken & & & & \\
\hline 31) & Eggs of goose & & & & \\
\hline 32) & Eggs of quail & & & & \\
\hline 33) & Fresh Milk & & & & \\
\hline 34) & Milk powder & & & & \\
\hline 35) & Condensed milk & & & & \\
\hline 36) & Spinach & & & & \\
\hline 37) & Water spinach & & & & \\
\hline 38) & Cucumber & & & & \\
\hline 39) & Carrots & & & & \\
\hline 40) & Sprout & & & & \\
\hline 41) & String bean & & & & \\
\hline 42) & Garlic & & & & \\
\hline 43) & Chili & & & & \\
\hline 44) & Tomato & & & & \\
\hline 45) & Onion & & & & \\
\hline 46) & Bitter gourd & & & & \\
\hline 47) & Eggplant & & & & \\
\hline 48) & Cabbage & & & & \\
\hline
\end{tabular}

HH number: 


\begin{tabular}{|c|c|c|c|c|c|}
\hline & \multirow{3}{*}{$\begin{array}{c}\text { Quantity } \\
\text { consumed in last } \\
\text { week (units) }\end{array}$} & \multirow{2}{*}{\multicolumn{2}{|c|}{ Unit (number, liter, kg, bag, pieces, etc.) }} & \multirow{3}{*}{$\begin{array}{c}\text { Market price, } \\
\text { if purchased } \\
\text { (Rp./unit) }\end{array}$} \\
\hline & & & & & \\
\hline \multicolumn{2}{|c|}{ Item consumed } & & & & \\
\hline 49) & Beans & & & & \\
\hline 50) & Pulses & & & & \\
\hline 51) & Grams & & & & \\
\hline 52) & Kacang Tanah & & & & \\
\hline 53) & Soybeans & & & & \\
\hline 54) & Cashew & & & & \\
\hline 55) & Tofu & & & & \\
\hline 56) & Tempe & & & & \\
\hline 57) & Tauco & & & & \\
\hline 58) & Oncom & & & & \\
\hline 59) & Orange & & & & \\
\hline 60) & Mango & & & & \\
\hline 61) & Apple & & & & \\
\hline 62) & Durian & & & & \\
\hline 63) & Rambutan & & & & \\
\hline 64) & Salak & & & & \\
\hline 65) & Duku & & & & \\
\hline 66) & Pineapple & & & & \\
\hline 67) & Watermelon & & & & \\
\hline 68) & Banana & & & & \\
\hline 69) & Papaya & & & & \\
\hline 70) & Jack fruit & & & & \\
\hline 71) & Avocado & & & & \\
\hline 72) & Guava & & & & \\
\hline 73) & Grapes & & & & \\
\hline 74) & Snake fruit & & & & \\
\hline 75) & Dragon fruit & & & & \\
\hline 76) & Coconut (whole) & & & & \\
\hline 77) & Coconut milk & & & & \\
\hline 78) & Other fresh fruits & & & & \\
\hline 79) & Dry fruits & & & & \\
\hline 80) & Honey & & & & \\
\hline 81) & Coconut oil & & & & \\
\hline 82) & Palm oil & & & & \\
\hline 83) & Soybean oil & & & & \\
\hline 84) & Other cooking oil & & & & \\
\hline 85) & Butter & & & & \\
\hline 86) & Sugar & & & & \\
\hline 87) & Brown sugar & & & & \\
\hline 88) & Tea & & & & \\
\hline 89) & Coffee & & & & \\
\hline
\end{tabular}

HH number: 


\begin{tabular}{|c|c|c|c|c|c|}
\hline & \multirow{3}{*}{$\begin{array}{c}\text { Quantity } \\
\text { consumed in last } \\
\text { week (units) }\end{array}$} & \multirow{2}{*}{\multicolumn{2}{|c|}{ Unit (number, liter, kg, bag, pieces, etc.) }} & \multirow{3}{*}{$\begin{array}{c}\text { Market price, } \\
\text { if purchased } \\
\text { (Rp./unit) }\end{array}$} \\
\hline & & & & & \\
\hline \multicolumn{2}{|c|}{ Item consumed } & & & & \\
\hline 90) & Chocolate & & & & \\
\hline 91) & Syrup & & & & \\
\hline 92) & Salt & & & & \\
\hline 93) & Candlenut fruit & & & & \\
\hline 94) & Coriander & & & & \\
\hline 95) & Pepper & & & & \\
\hline 96) & Shrimp paste & & & & \\
\hline 97) & Soy sauce & & & & \\
\hline 98) & Taste enhancer & & & & \\
\hline 99) & Ginger & & & & \\
\hline 100) & Crackers & & & & \\
\hline 101) & Melinjo crackers & & & & \\
\hline 102) & Noodles & & & & \\
\hline 103) & Rice noodles & & & & \\
\hline 104) & Macaroni noodles & & & & \\
\hline 105) & Bread & & & & \\
\hline 106) & Biscuits & & & & \\
\hline 107) & Cakes & & & & \\
\hline 108) & Porridge & & & & \\
\hline 109) & Meatballs & & & & \\
\hline 110) & Iced syrup & & & & \\
\hline 111) & $\begin{array}{l}\text { Assorted } \\
\text { vegetable with } \\
\text { peanut sauce } \\
\end{array}$ & & & & \\
\hline 112) & $\begin{array}{l}\text { Rice and various } \\
\text { side dishes }\end{array}$ & & & & \\
\hline 113) & Snacks & & & & \\
\hline 114) & Readymade soups & & & & \\
\hline 115) & Canned food & & & & \\
\hline 116) & Kaledo & & & & \\
\hline 117) & Mie instan & & & & \\
\hline 118) & Nasigoreng & & & & \\
\hline 119) & Nasikuning & & & & \\
\hline 120) & Nasi Bungkus & & & & \\
\hline 121) & Fried bananas & & & & \\
\hline 122) & Baby food & & & & \\
\hline 123) & Bottled water & & & & \\
\hline 124) & Cola, soda etc. & & & & \\
\hline 125) & Fresh fruit juices & & & & \\
\hline 126) & Lemonade & & & & \\
\hline 127) & Clove cigarettes & & & & \\
\hline
\end{tabular}

HH number: 


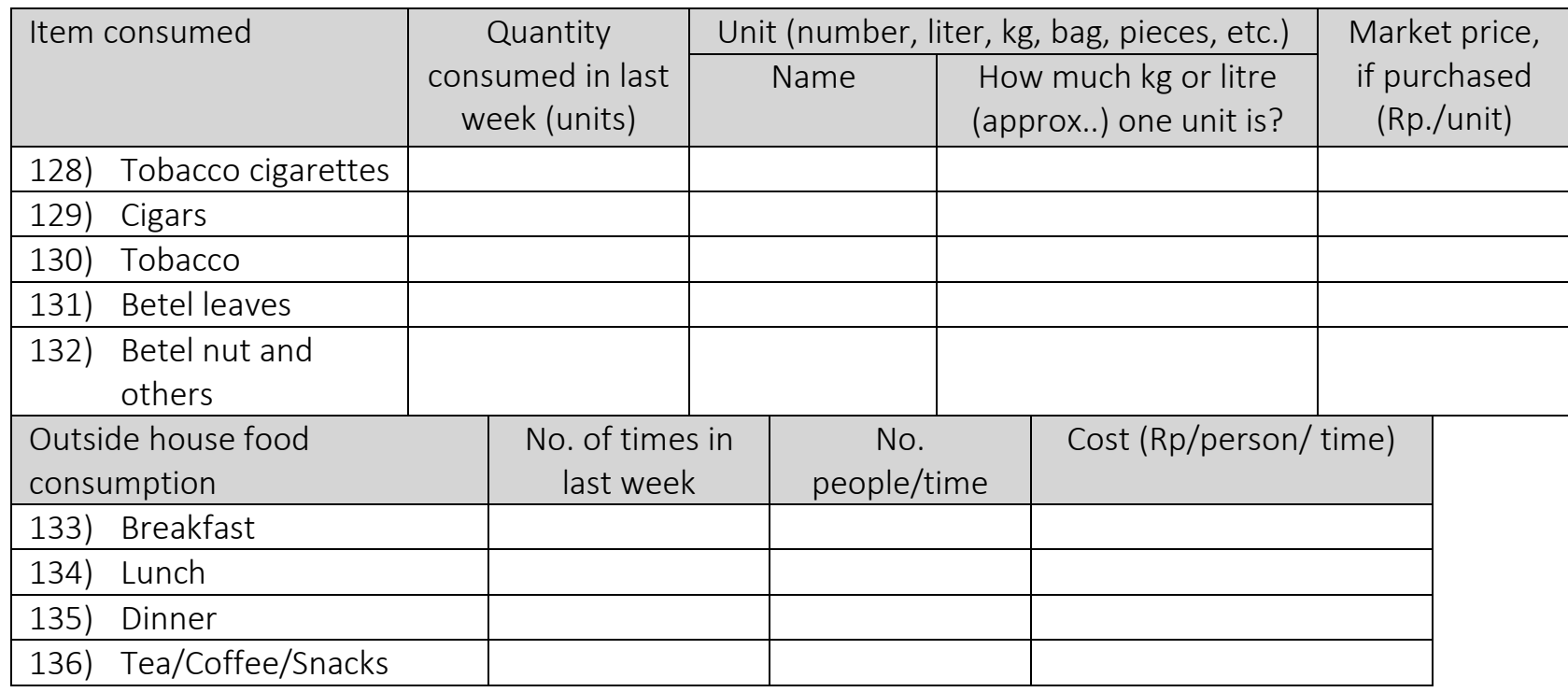

2.2. Monthly and annual consumption: Has your household bought or received gifts of during the past 30 days/ 12 months? Please exclude from your answer any purchases for processing or resale in a household enterprise.

\begin{tabular}{|c|c|c|c|}
\hline \multicolumn{2}{|l|}{ Item } & \multirow[t]{2}{*}{$\begin{array}{l}\text { Monthly expenditure } \\
\text { (Rp./month) }\end{array}$} & \multirow[t]{2}{*}{$\begin{array}{l}\text { Yearly expenditure (Rp. } \\
\text { /year) }\end{array}$} \\
\hline 137) & Rent of house if contracted & & \\
\hline 138) & Rent, estimated if house is owned & & \\
\hline 139) & Electricity bill & & \\
\hline 140) & Telephone bill (fixed phone line) & & \\
\hline 141) & Gas bill (kitchen) & & \\
\hline 142) & Kerosene bill & & \\
\hline 143) & Water bill & & \\
\hline 144) & Firewood & & \\
\hline 145) & House maintenance and renovation & & \\
\hline 146) & $\begin{array}{l}\text { Personal care items (soap, shampoo, } \\
\text { toothpaste, etc.) }\end{array}$ & & \\
\hline 147) & $\begin{array}{l}\text { Personal services (haircuts, shaving, } \\
\text { etc.) }\end{array}$ & & \\
\hline 148) & Cosmetics & & \\
\hline 149) & Tailoring expenses & & \\
\hline 150) & Laundry & & \\
\hline 151) & Newspaper and magazines & & \\
\hline 152) & Membership fees & & \\
\hline 153) & Toys & & \\
\hline 154) & Making of ID card/ drivers license & & \\
\hline 155) & Telephone card (mobile phone) & & \\
\hline 156) & Postal goods & & \\
\hline 157) & Recreation & & \\
\hline
\end{tabular}

$\mathrm{HH}$ number: 


\begin{tabular}{|c|c|c|}
\hline Item & $\begin{array}{l}\text { Monthly expenditure } \\
\text { (Rp./month) }\end{array}$ & $\begin{array}{l}\text { Yearly expenditure (Rp. } \\
\text { /year) }\end{array}$ \\
\hline 158) Entertainment (e.g., movies, drama) & & \\
\hline 159) Travel & & \\
\hline 160) Ornaments & & \\
\hline 161) Registration fee & & \\
\hline 162) SPP & & \\
\hline $\begin{array}{l}\text { 163) POMG/BP3 /entrance- / re-registration } \\
\text { fee }\end{array}$ & & \\
\hline 164) Boy scout & & \\
\hline 165) Handcraft & & \\
\hline 166) Courses & & \\
\hline 167) Hospital & & \\
\hline 168) Community health center & & \\
\hline 169) Doctor's practice & & \\
\hline 170) Traditional healer & & \\
\hline 171) Medicine & & \\
\hline 172) Footwear (men, women and children) & & \\
\hline 173) Clothing (men, women and children) & & \\
\hline 174) Household tools & & \\
\hline 175) Hand tools & & \\
\hline 176) Kitchen tools & & \\
\hline 177) Tele vision & & \\
\hline 178) Dish TV & & \\
\hline 179) Other entertainment facilities & & \\
\hline 180) Sports equipment & & \\
\hline 181) Jewelry & & \\
\hline 182) Vehicles & & \\
\hline 183) Umbrellas & & \\
\hline 184) Wristwatch & & \\
\hline 185) Camera & & \\
\hline 186) Install telephone & & \\
\hline 187) Install electricity & & \\
\hline 188) Electronic equipment & & \\
\hline $\begin{array}{l}\text { 189) Taxes (House and building tax, TV fee, } \\
\text { motor vehicle tax) }\end{array}$ & & \\
\hline 190) Insurance (accident, health insurance) & & \\
\hline 191) Celebration 1 (name: & & \\
\hline 192) Celebration 2 (name:_ & & \\
\hline 193) Celebration 3 (name: & & \\
\hline $\begin{array}{l}\text { Did you make expenses in last year for any } \\
\text { other item? }\end{array}$ & & Yes/ No \\
\hline If yes (name and expense) & & \\
\hline
\end{tabular}

HH number: 


\begin{tabular}{|l|c|c|}
\hline Item & $\begin{array}{c}\text { Monthly expenditure } \\
\text { (Rp./month) }\end{array}$ & $\begin{array}{c}\text { Yearly expenditure (Rp. } \\
\text { /year) }\end{array}$ \\
\hline & & \\
\hline
\end{tabular}

2.3 Consumption of energy (fuel, light \& household appliances) during the last 30 days ended on

\begin{tabular}{|c|c|c|c|c|}
\hline \multicolumn{2}{|l|}{ Item } & \multirow[t]{2}{*}{ Unit (name) } & \multirow[t]{2}{*}{$\begin{array}{c}\text { Quantity consumed in last } \\
\text { one month (units) }\end{array}$} & \multirow[t]{2}{*}{$\begin{array}{l}\text { Market price (Rp. /unit) if } \\
\text { purchased } \\
\end{array}$} \\
\hline 194) & Dung cake & & & \\
\hline 195) & Coal, Charcoal, Briquettes, coke & & & \\
\hline 196) & LPG [excl. conveyance] & & & \\
\hline 197) & $3 \mathrm{~kg}$ (subsidized) & & & \\
\hline 198) & 15 kg (non subsidized) & & & \\
\hline 199) & Battery & & & \\
\hline 200) & Accu/ aki (car battery) & & & \\
\hline 201) & Generator & & & \\
\hline 202) & Petrol & & & \\
\hline 203) & Diesel & & & \\
\hline 204) & Lubricants oil & & & \\
\hline 205$)$ & $\begin{array}{l}\text { Oil for generator maintenance } \\
\text { (minyak rem, kanvas, etc) }\end{array}$ & & & \\
\hline 206) & Other fuel & & & \\
\hline 207) & $\begin{array}{l}\text { Other consumption (Matches, } \\
\text { Candle, air freshener, Mosquito } \\
\text { repellent etc) }\end{array}$ & & & \\
\hline
\end{tabular}

2.4 Public transport expenditures during the last 30 days ended on

\begin{tabular}{|c|c|c|}
\hline Item & & Total expenditure in last month (Rp) \\
\hline 208) & Public bus/tram fare & \\
\hline 209) & Public minibus (angkot) fare & \\
\hline 210) & Air fare & \\
\hline 211) & Public motorcycle (ojek) & \\
\hline 212) & Taxi, auto-rickshaw fare & \\
\hline 213) & Rental car & \\
\hline 214) & $\begin{array}{l}\text { Other public conveyance expense (such as } \\
\text { porter charges, horse cart fare, etc) }\end{array}$ & \\
\hline
\end{tabular}

HH number: 
2.5 Private transport expenditures during the last 30 days ended on

\begin{tabular}{|c|c|c|c|}
\hline Item & & $\begin{array}{c}\text { Fuel cost in last } \\
\text { month (Rp) }\end{array}$ & $\begin{array}{l}\text { Other expenditures in last month } \\
\text { (Iubricants, other fuel for vehicle, oil for } \\
\text { maintenance, etc) in Rp. }\end{array}$ \\
\hline 215$)$ & Private car & & \\
\hline 216) & Private minibus & & \\
\hline 217) & Private bus & & \\
\hline 218) & Private motorcycle & & \\
\hline 219) & Other private transport (please mention) & & \\
\hline
\end{tabular}

2.6 Religion of the household members: Islam/Others

If Islam, have any of the household members gone to Hadj? Yes/No

If yes, details of past pilgrimages:

\begin{tabular}{|c|c|c|}
\hline Year of Hadj & $\begin{array}{c}\text { Number of household members } \\
\text { went }\end{array}$ & $\begin{array}{c}\text { If gone for Hajj in the last 5 years, } \\
\text { expenditure incurred (million Rp) }\end{array}$ \\
\hline & & \\
\hline & & \\
\hline
\end{tabular}

Are you planning to go for Hadj in the near future? Yes/No

If yes, are you saving for Hadj, currently? Yes/No

If yes, average savings, kept for this purpose: .............. thousand Rp/year.

HH number: 